\title{
China's Policymaking on Regional Economic Cooperation
}

\author{
Yang Jiang \\ Department of International Relations \\ Research School of Pacific and Asian Studies \\ The Australian National University
}

May 2008

A thesis submitted for the degree of Doctor of Philosophy of The Australian National University. 


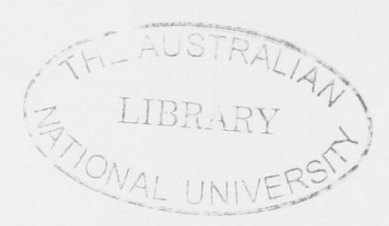




\section{Statement of Authenticity}

I declare that the thesis is my own original work and all sources have been acknowledged.

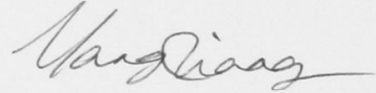

Yang Jiang

28 May 2008 
In Memory of My Grandpa Mao Xianghong 


\section{Contents}

Acknowledgements $\quad$ V

List of Abbreviations $\quad$ vi

Abstract viii

$\begin{array}{lll}\text { Chapter } 1 \quad \text { Introduction } & 1\end{array}$

Chapter $2 \quad$ Conceptualizing Foreign Economic Policymaking in the 21

Chapter $3 \quad$ Preferences in the China-ASEAN Free Trade Agreement 81

Chapter $4 \quad$ China's Policymaking Process for the China-ASEAN Free 110

$\begin{array}{lll}\text { Chapter } 5 & \text { China's Policymaking on the Australia-China FTA } & 151\end{array}$

Chapter $6 \quad$ China’s Policymaking on Regional Financial Cooperation 199

Conclusion $\quad$ Interests, Ideas and Institutions in China’s Policymaking 248 on Regional Economic Cooperation

Appendix List of Affiliations of Interviewees and Number of Interviewees 


\section{Acknowledgements}

I received help from many people on this thesis but most of all I want to thank my supervisor John Ravenhill, who has guided me through every step of the $\mathrm{PhD}$ and made the whole process immensely memorable and valuable. The thesis and my academic growth would not have been possible without his constant support and encouragement. His professionalism and dedication to research and teaching will continue to guide me in my future career. Words cannot fully express my gratitude to him.

My advisors, Stuart Harris and Peter Van Ness, have given me insightful suggestions and comments on research plans and chapter drafts with their deep understanding of China and regional issues, and have been great sources of inspiration for a young scholar like myself. Other members of the Department, notably William Tow, Paul Keal, Kathy Morton, Raymond Apthorpe and Christian Reus-Smit have provided valuable support during my study at the Australian National University (ANU). Ligang Song, Ross Garnaut and Ann Kent from other departments of ANU also helped me at different stages of my $\mathrm{PhD}$ study.

The PhD study has been supported by the ANU PhD Scholarship and the International Postgraduate Research Scholarship (IPRS), and the two rounds of fieldwork were funded by the Departmental Funding for Fieldwork Research and the ANU-Beijing University Exchange Fellowships. My Visiting Fellowships at Beijing University and the China Academy of Social Sciences were very useful during my fieldwork in China. I also owe a great debt to my interviewees in China and Australia who are the major source of information in the thesis, but are kept anonymous in the thesis for confidentiality reasons. I have been constantly impressed by their openness and respect for academic research. I hope the production and publication of the thesis will be a way to thank the above institutions and persons.

The $\mathrm{PhD}$ process has been made easier by the support from my friends at ANU. I thank Brendan Taylor, Miwa Hirono, Jikon Lai, Mathew Davies and Vasoontara Yieng in particular for their friendship. I would like to thank Christopher Hobson especially for his support.

Finally, I owe great debts to my parents Jiang Shuncheng, Mao Wenyong and Grandma Li Renjie. I would not have traveled this far without their love and understanding. 


\section{List of Abbreviations}

\begin{tabular}{|c|c|}
\hline ABM & Asian Bond Market \\
\hline $\mathrm{ACU}$ & Asian Currency Unit \\
\hline $\mathrm{ADB}$ & Asian Development Bank \\
\hline AFTA & ASEAN Free Trade Area \\
\hline AMF & Asian Monetary Fund \\
\hline AMU & Asian Monetary Unit \\
\hline AMWU & Australia Manufacturing Workers Union \\
\hline APEC & Asia Pacific Economic Cooperation \\
\hline ARF & ASEAN Regional Forum \\
\hline ASEAN & Association of Southeast Asian Nations \\
\hline $\mathrm{ASEAN}+3$ & ASEAN, China, Japan, South Korea \\
\hline ASEM & Asia-Europe Meeting \\
\hline AUCFTA & Australia-China Free Trade Agreement \\
\hline BSA & Bilateral Swap Arrangement \\
\hline CAFTA & China-ASEAN Free Trade Agreement \\
\hline CASS & Chinese Academy of Social Sciences \\
\hline CBRC & China Banking Regulatory Commission \\
\hline \multirow[t]{2}{*}{$\mathrm{CCP}$} & Chinese Communist Party \\
\hline & China-Hong Kong Closer Economic Partnership \\
\hline CEPA & Arrangement \\
\hline CER & Australia-New Zealand Closer Economic Relations \\
\hline CET & Committee of Economy and Trade of State Council \\
\hline CICIR & China Institute of Contemporary International Relations \\
\hline $\mathrm{CMI}$ & Chiang Mai Initiative \\
\hline $\mathrm{CNOOC}$ & China National Overseas Oil Corporraation \\
\hline DFAT & Australian Department of Foreign Affairs and Trade \\
\hline EHP & Early Harvest Programme \\
\hline EMEAP & Executives' Meeting of East Asia and Pacific Central Banks \\
\hline \multirow[t]{2}{*}{ ERPD } & Economic Review and Policy Dialogue \\
\hline & Technical Working Group on Economic and Financial \\
\hline ETWG & Monitoring \\
\hline $\mathrm{EU}$ & European Union \\
\hline FDI & Foreign Direct Investment \\
\hline FIRB & Australian Foreign Investment Review Board \\
\hline FTA & Free Trade Agreement/Area \\
\hline GATT & General Agreement on Tarrifs and Trade \\
\hline
\end{tabular}




\begin{tabular}{ll} 
GCC & Gulf Cooperation Council \\
IFTEC & Institute of Foreign Trade and Economic Cooperation \\
IMF & International Monetary Fund \\
IPR & Intellectual Property Rights \\
LDC & Least Developed Country \\
LNG & Liquefied Natural Gas \\
MES & Market Economy Status \\
MFA & Ministry of Foreign Affairs \\
MFN & Most Favoured Nation \\
MII & Ministry of Information Technology \\
MOA & Ministry of Agriculture \\
MOF & Ministry of Finance \\
MOFCOM & Ministry of Commerce \\
MOFTEC & Ministry of Foreign Trade and Economic Cooperation \\
NAFTA & North American Free Trade Agreement \\
NDRC & National Development and Reform Commission \\
NPC & National People's Congress \\
NTB & Non-Tariff Barriers to Trade \\
OCA & Optimum Currency Area \\
PAFTAD & Pacific Trade and Development Forum \\
PECC & Pacific Economic Cooperation Council \\
QFII & Qualified Foreign Institutional Investors \\
SACU & South African Customs Union \\
SCO & Shanghai Cooperation Organisation \\
SinoPec & China Petroleum and Chemical Corporation \\
SOE & State-Owned Enterprise \\
SPS & Sanitary and Phytosanitary Measures \\
UN & Thiters to Trade \\
US & Unites \\
\hline
\end{tabular}




\title{
China's Policymaking on Regional Economic Cooperation
}

\begin{abstract}
What factors determine China's policies on regional economic cooperation; in particular, why have some interests or ideas have prevailed in policymaking at the expense of others? The thesis adopts historical institutionalism to explore how institutions have structured the interactions among policy preferences and sometimes even shaped their formation, and how institutions have developed during the process of policymaking despite a tendency to resist change. The empirical information draws from three in-depth case studies, namely, the ChinaASEAN Free Trade Agreement (FTA), the Australia-China FTA and East Asian financial cooperation. The research has been conducted mainly in the form of interviews in China and Australia in 2006 and 2007, supplemented with primary and secondary documents. In each of the case studies, the thesis introduces the interests and ideas that have been important policy inputs into China's regional economic cooperation, and analyzes the role of institutions in shaping and structuring the interactions among policy preferences. In particular, the thesis investigates how various policy outcomes can be explained by reference to three variables central to institutionalist approaches, namely, the degree of insulation of the central policymaker from domestic interest groups, the degree of collective action within each domestic interest group, and the degree of fragmentation of the state policymaking power. Three sources of institutional change in China's policymaking on regional economic cooperation are identified: institutional learning, the emergence of a new policy area, and the change in the composition of key actors. Empirically, the thesis contributes to studies of China and regionalism with new data; theoretically, it supports an integrated approach to policymaking analysis by combining interests, ideas and institutions, and it underlines the importance of domestic factors for understanding a state's international behaviour.
\end{abstract}




\section{Chapter 1 Introduction}

\section{The Research Topic}

The world political economy at the start of the 21 st century is faced with two major questions. First, where is global economic liberalization going, when regional economic arrangements are proliferating? Second, what will be the impact of a rising China on other countries and the world as a whole? At the juncture of these two questions is China's notable activity in regional economic cooperation. ${ }^{1}$ Whether watching with awe, doubt or hope, other countries are wondering: when China conducts regional economic diplomacy, what are its ambitions and to what extent is it able to realise those ambitions?

Just as their ancestors in the Han Dynasty believed that the world would be peaceful if it was upheld by three poles, many Chinese today promote the merit of multi-polarisation for world peace and development. Whether or not the pursuit of multipolarity is the true motivation for China's increasing activity in regional economic cooperation since the late 1990s, Beijing's move has caused much scholarly and policy attention. There have been numerous attempts to interpret the nature, or predict the trajectory of such foreign economic policy behaviour of China, without, however, much knowledge of how such policies came into being. The structure, process and other domestic features of Chinese foreign economic policymaking have largely remained an enigma because of their opaque and complex characteristics. ${ }^{2}$ This study tries to open the black box by exploring how China makes policies on regional economic cooperation.

This chapter will first discuss the two major issues mentioned above as the context for the study. First, it introduces the tension between global economic liberalization and regional economic cooperation, and highlights a crucial development - the new bilateralism in the Asia

\footnotetext{
${ }^{1}$ Regional economic cooperation refers to inter-governmental economic arrangements within a geographical proximity. Regionalism is described in the Dictionary of Trade Policy Terms, as "actions by governments to liberalize or facilitate trade on a regional basis, sometimes through free-trade areas or customs unions". In the WTO context, regional trade agreements (RTAs) refer to agreements concluded between countries not necessarily belonging to the same geographical region and WTO provisions relate specifically to conditions of preferential trade liberalization with RTAs. There is economic cooperation among regional societies as well, but they are often referred to as 'sub-regional cooperation'. Moreover, inter-governmental economic arrangements are the most politically controversial policies at the national level.

${ }^{2}$ Foreign economic policymaking is defined as the process in which a country's policy elites, government bureaucrats, interest groups and other actors incorporate their interests and ideas under certain institutional settings to decide the country's foreign economic policies.
} 
Pacific. Second, it focuses on one of the major actors in that front- China, with its economic rise and liberalization. Joining those two issues together, the next section focuses on China's growing activism in regional economic cooperation. Because knowledge of domestic policymaking is needed - yet lacking — in the understanding of those particular foreign economic policies of China as will be discussed in the next chapter, the following section focuses on the domestic context within which decision-making occurs in China, which leads to questions of why the Chinese government sometimes is, and other times is not, able to sign regional trade and financial agreements. To address these specific issues, the leading research question of the study will be raised: what factors determine China's policies on regional economic cooperation? This is followed by an outline of the thesis and a brief summary of the argument.

\section{Background}

\subsection{Global and/or regional?}

Currently a major tension within the world economy is a struggle between global

liberalization and regional arrangements. Believers in multilateral free trade are mostly worried that regional agreements will undermine the global trading regime, given that the proliferation of preferential trade agreements are seldom linked with one another. ${ }^{3}$ In a similar vein, global financial institutions are cautious of the role of regional financial initiatives, fearing that the latter will cause moral hazard problems or dilute their mandate in domestic reforms. ${ }^{4}$ At the same time, however, some regional blocs strive for a louder voice in global financial arenas.

In trade, on the one hand, the World Trade Organization (WTO) is facing seemingly insurmountable obstacles in making any further progress on trade liberalization, as its

\footnotetext{
${ }^{3}$ For the debate on the relationship between regional trade agreements and global trade liberalization, see Jagdish N. Bhagwati, Pravin Krishna, and Arvind Panagariya, Trading blocs: Alternative Approaches to Analyzing Preferential Trade Agreements (Cambridge, Mass.: MIT Press, 1999). Jo-Ann Crawford and Sam Laird, "Regional Trade Agreements and the WTO," North American Journal of Economics and Finance 12 (2001). Nicholas JS Lockhart and Andrew D Mitchell, "Regional Trade Agreements under GATT 1994: An Exception and Its Limits," in Challenges and Prospects for the WTO, ed. Andrew D Mitchell (London: Cameron May, 2005).

${ }^{4}$ David P. Rapkin, "The United States, Japan and the Power to Block: The APEC and AMF Cases", The Pacific Review 14, 3 (2001): 373-410. Wendy Dobson, "Greater Integration in East Asia: Regional Institutions and the International Economic System”, The World Economy, 24, 8 (2002): 995-1018.
} 
membership expands and more issues are placed on the negotiation table. This once privileged club of "fair-trade" partners is now losing credibility both in guaranteeing membership privileges and in enforcing obligations. Each WTO Ministerial Meeting in Seattle, Doha, Cancún, and Hong Kong was a heavy step fraught with arguments, and the suspension of the Doha round in 2006 epitomised the problems caused by conflicting national interests, such as the debate over agricultural protection by developed countries. A critical question is whether significant economic powers - including the US, the European Union (EU) and China - will stick to the WTO approach to trade liberalization or abandon it for alternatives.

On the other hand, regional economic arrangements are mushrooming in almost every corner of the earth. Following the first wave of post-war regional integration in Europe and Latin America, regionalism in a new wave at the turn of the century has been taken up by most countries in the world, usually in the form of free trade agreements (FTA) ${ }^{6}$ These new agreements involve not only economies in transition but also traditional advocates of free trade and open economic systems; they are not necessarily between countries of geographic proximity, although they are still called 'regional' (according to tradition as well as by the WTO); and they are not obviously aimed at integration among the partners through complete removal of barriers to movements of goods, capital and labour. GATT Article XXIV allows the formation of regional free trade areas on the condition that they eliminate restrictive regulations of commerce in 'substantially all trade' between the parties. The vagueness of this clause is often blamed for the proliferation of preferential trade agreements. However, the development of FTAs from the inception of GATT in 1947 until the late 1990s was slow, which probably reflected a lack of domestic demand for such agreements, the constraint by Article XXIV over regionalism, and the US's commitment to multilateralism. Following the "defection" of the US from multilateralism through its FTAs with Israel, Canada and through the North American Free

\footnotetext{
${ }^{5}$ Here 'fair trade' refers to the principle of the most favoured nation (MFN) treatment of the GATT, in contrast with 'unfair' international trade practices. Note that here it is different from the term 'fair trade' widely used today as activities that promote exports, mostly handicrafts and agricultural products, from least developed countries to developed countries.

${ }^{6}$ See Jagdish N. Bhagwati, "Regionalism and Multilateralism: An Overview," in New Dimensions in Regional Integration, ed. Jaime de Melo and Arvind Panagariya (New York: Cambridge University Press, 1993). Edward Mansfield and Helen V. Milner, "The New Wave of Regionalism," International Organization 53, no. 3 1999). Shaun Breslin and Richard Higgott, "Studying Regions: Learning from the Old, Constructing the New," New Political Economy 5, no. 3 (2000). 'FTA' stands for both free trade areas and free trade agreements in this thesis, as is commonly used.
} 
Trade Agreement (NAFTA), ${ }^{7}$ a major change at the start of the $21^{\text {st }}$ century is arguably the joining of East Asia in general, and China in particular, into the 'encircling' game, which has made demands by some states for regionalism much stronger, and the constraints of Article XXIV on them even weaker.

Optimists hope regional blocks would join to eventually build up global liberalization. However, more people seem to see the current relationship between global and regional economic cooperation as a life-and-death struggle - irreconcilability between multilateralism and bilateralism, between open and closed trading systems, and between equal treatment for all and discrimination. Critics have little difficulty in pointing out the discriminatory and protective nature of the so-called 'free' trade agreements: they not only divert trade and investment from third countries but also carve out sensitive sectors from intra-regional liberalization. They also add transaction costs and confusion to world trade with specific and restrictive rules of origin, hindering free and fair development of international production networks. In Bhagwati's words, preferential trade agreements fragment the world trading system into a 'spaghetti bowl' ${ }^{8}$ FTAs between big economic powers and small ones are deemed as most problematic because the inequality of concessions in such agreements often reflects the power imbalance between the countries. Moreover, further development of regionalism can lead to several hub-and-spoketype trade empires that battle for spheres of influence, resulting in potentially very damaging conflicts.

In finance, there seems less tension between globalism and regionalism but the relationship is nevertheless sensitive. The successful adoption of the Euro by the EU was hailed as the achievement of fifty years' foundational work, entailing the formation of a security area and significant liberalization of national economies in trade, financial systems and labour markets. As European financial integration promotes economic liberalization, it is in accordance with the spirit of global financial institutions represented by the IMF. However, East Asian financial regionalism has not always been regarded as supportive of the global financial system. Rather, it sprouted from disappointment in the region over the inadequate help that the IMF

\footnotetext{
${ }^{7}$ John Ravenhill, "The New Bilateralism in the Asia Pacific," Third World Quarterly 24, no. 2 (2003).

${ }^{8}$ Jagdish N. Bhagwati and Anne O. Krueger, The Dangerous Drift to Preferential Trade Agreements, AEI Special Studies in Policy Reform (Washington, D.C.: AEI Press, 1995).
} 
extended during the Asian financial crisis. It questions the imposition of the conditionality of IMF loans on developing countries and explores the possibility of a less stringent regional mechanism for crisis management, as well as a currency area that is independent of the US dollar. Although the attitude of the IMF towards East Asian financial regionalism has changed from outright objection towards qualified approval, the potential of East Asian countries gaining a louder voice at international financial institutions by forming a group could still be a challenge to the existing rules of the global game.

\subsection{The new bilateralism in the Asia Pacific}

Countries in the Asia Pacific have taken the lead in the latest wave of regionalism, featuring bilateral economic agreements. ${ }^{9}$ Before the turn of the $21^{\text {st }}$ century, Asian regional cooperation was characterised by informality and low levels of institutionalization, in contrast to the EU and the NAFTA. The major grouping for economic cooperation in the Asia Pacific was the Asia-Pacific Economic Cooperation (APEC), a forum advocating non-discriminatory 'open regionalism' and unilateral voluntary trade liberalization. Another regional group, the Association of Southeast Asian Nations (ASEAN), was heralded for its unique organizational culture - the "ASEAN way" - characterised by consensus seeking, informality, flexibility and sovereignty instead of conflict, restriction and interference in each other's autonomy. ${ }^{10}$

Although ASEAN was implementing a free trade agreement, this preferential agreement had not prevented ASEAN economies undertaking significant unilateral trade liberalization, consistent with APEC's approach, from the mid-1980s onwards. When the Asian financial crisis hit the region in 1997, East Asian regionalism gained momentum in the form of ASEAN+1 and ASEAN +3 (the three being China, Japan and South Korea) dialogues. Some East Asian countries came up with proposals for an East Asia Free Trade Area and an Asian Monetary Fund, but both were shelved as being 'premature' because of competition for regional

\footnotetext{
${ }^{9}$ Ravenhill, "The New Bilateralism in the Asia Pacific."

${ }^{10}$ Amitav Acharya, "Ideas, Identity, and Institution-Building: From the 'ASEAN Way' to the 'Asia-Pacific Way'?," The Pacific Review 10, no. 3 (1997).
} 
leadership, lack of political trust between countries in East Asia, and concerns from countries outside the region about potentially being excluded. ${ }^{11}$

Tension still exists between East Asian and Asia-Pacific models of regional economic cooperation, but it has not hindered the spread of bilateralism. In finance, a set of bilateral swap arrangements, the Chiang Mai Initiative, was achieved between Southeast Asian and three Northeast Asian countries in 2000, and upgraded at the ASEAN+3 Finance Ministers Meeting in Istanbul in 2005. Although East Asian countries started exploring multilateralizing the CMI in 2006, they are far from reaching consensus on important issues for meaningful multilateral cooperation, such as supranational decision-making and supervision, because of sensitivities over their sovereignty. ${ }^{12}$ In trade, proposals for South Korea-Chile, Japan-South Korea, South Korea-Thailand FTAs in 1998, and particularly China's proposal of an FTA to ASEAN in 1999, started a domino effect of bilateral trade agreements in the Asia Pacific. The structure of Asian economic cooperation is changing from looseness to strings, formed not only between regional countries but also with countries outside the region. Some Asian countries argue that the frustration with global economic regimes such as the $\mathrm{WTO}$ and the IMF, and the proliferation of regionalism elsewhere, left them little choice but to negotiate market access through their own regional agreements; otherwise they would be left out with 'less-than-MFN' treatments. ${ }^{13}$ One important motivation for the growth of bilateral economic cooperation in the Asia Pacific is that countries in the region are important growing markets for each other and for countries outside the region as well, and a competition of market access is easily triggered if one starts to give preferential treatment to another.

\footnotetext{
${ }^{11}$ Richard Stubbs, "ASEAN Plus Three: Emerging East Asian Regionalism?," Asian Survey 42, no. 3 (2002). Phillip Y. Lipscy, "Japan's Asian Monetary Proposal," Stanford Journal of East Asian Affairs 3, no. 1 (Spring 2003).

12 Jennifer Amyx, "What Motivates Regional Financial Cooperation in East Asia Today?," Asia-Pacific Issues Paper, East-West Center, no. 76 (March 2005). Jennifer Amyx, "Regional Financial Cooperation in East Asia since the Asian Financial Crisis," in Crisis as Catalyst: Asia's Dynamic Political Economy, ed. Andrew Macintyre, T.J. Pempel, and John Ravenhill (Ithaca: Cornell University Press, 2008). Fan He, Bin Zhang, and Ming Zhang, "After the CMI: The Future of Asian Monetary Cooperation and China's Role", ASEAN+3 Research Group Studies 2004-2005, 2005.

${ }^{13}$ Masahiro Kawai, "East Asian Economic Regionalism: Progress and Challenges", Journal of Asian Economics 16, 1 (2005): 29-55. John Ravenhill, "A Three Bloc World? The New East Asian Regionalism," International Relations of the Asia-Pacific 2 (2002). David Capie, "Rival Regions? East Asian Regionalism and Its Challenge to the Asia-Pacific," in Jim Rolfe, ed., The Asia-Pacific: A Region in Transition (Honolulu: Asia-Pacific Center for Security Studies, 2004), 149-165.
} 
Conventional wisdom is that many East Asian states have authoritarian political systems, and therefore they can be treated as unitary actors in the study of international relations. As a result, studies on Asian regional economic cooperation have to a large extent stayed at the state level, focusing on macroeconomic factors or international relations while giving little attention to the domestic politics of economic policymaking. ${ }^{14}$ These studies assume that in East Asian countries domestic interest groups have little influence over policymaking on foreign economic cooperation, and that policymakers have a clear and unified view about 'the national interest' in regional economic cooperation. However, it can be argued that within East Asian countries the state is not completely insulated from domestic pressures anymore, and that domestic opinions over regional economic cooperation vary not only between domestic interest groups and policymakers, but also among the policymakers.

First, as economic liberalization has progressed, various domestic groups have gained political power. Some East Asian countries have undergone democratization, and policymakers have to respond to both the voters and various special interest groups. Even in autocratic countries, the regime has to prove its legitimacy, and state power has to some extent been decentralized to local governments and fragmented among various bureaucracies. Second, most East Asian countries are developing countries, and are still dealing with practical and ideational dilemmas between trade liberalization and industrial development, and between adopting Western standards of institutional reform and keeping old institutions for autonomy and 'economic security'. Therefore, one cannot take it for granted that East Asian states are unitary actors. The policies an East Asian state adopts on regional economic cooperation will depend on what preferences the various domestic groups and policymakers hold, and how much influence they have over each other.

Most East Asian countries have relied heavily on external markets and capital for economic growth in the past two decades. Regionalism carries both opportunities for obtaining more market and capital in the region, as well as risks like compromising sovereignty, creating enhanced competition for domestic industries, as well as having complex politico-strategic implications. Adding to the complexity of the game of regional economic cooperation is China's

\footnotetext{
${ }^{14}$ John Ravenhill, "A Three Bloc World?". Breslin and Higgott, "Studying Regions."
} 
rise, and its participation in international economic cooperation, both globally and regionally,

both as an expansionist and a target of expansion.

\subsection{China rising and its liberalization}

China's rise is undoubtedly a significant factor in the world political economy since the turn of the century. Under the spotlight are China's size and more importantly, the speed of economic and political change. Some in the world applaud, and some watch sombrely. For those who acclaim, China's development represents market opportunities, cheap labour, or even a source of investment, having the potential to replace the US as the largest 'powerhouse' of the world economy. In the minds of many other state leaders, a 'China threat' still exists. This time, it is not so much due to concerns over Beijing's agenda being the expansion of communism as it had been before the 1980 s. It is now more from China's power and potential. ${ }^{15}$ If China's aim is simply to achieve economic development, it is a serious competitor. If China sees it is time to take revenge for its sufferings under imperial invasion in the $19^{\text {th }}$ century and capitalist isolation during the better half of the $20^{\text {th }}$ century, it could be a destructive revisionist force. Or, if its own problems get out of control, it could become the source of various epidemics. ${ }^{16}$ In response, China first stated that it only sought 'peaceful rise', a term that did little to extinguish others' doubts, and therefore Beijing altered the phrase to 'peaceful development', ${ }^{17}$ but this hardly helped to overcome other governments' concerns. When China expands global economic connections, it is possible to give others a lift, just as it is possible to bring damages to them.

Neither is it certain whether China will be able to realise its objectives smoothly.

\footnotetext{
${ }^{15}$ David L. Shambaugh, Power Shift: China and Asia's New Dynamics (Berkeley: University of California Press, 2005). Susan L. Shirk, China, Fragile Superpower: How China's Internal Politics Could Derail Its Peaceful Rise (New York: Oxford University Press, 2007). Robert G. Sutter, China's Rise in Asia: Promises and Perils (Lanham, MD.: Rowman \& Littlefield, 2005). Yong Deng and Fei-Ling Wang, eds., China Rising: Power and Motivation in Chinese Foreign Policy (Lanham, MD.: Rowman \& Littlefield, 2005).

${ }^{16}$ Certainly China's economic rise has profound demographic, environmental, cultural and military implications, but they are beyond the scope of this study.

${ }^{17}$ Bijian Zheng, China's Peaceful Rise: Speeches of Zheng Bijian 1997-2005 (Washington D.C.: Brookings Institution Press, 2005). The State Council of China, "China's Peaceful Development Road", White Paper, 22 December 2005, http://english.peopledaily.com.cn/200512/22/eng20051222_230059.html.
} 


\section{The path to liberalization}

The most powerful engine behind China's economic growth has been its economic liberalization and its integration into the outside world. A look back at the history of China's international economic engagement is useful to understand the present. Scholarly works usually take 1978, with the launch of the 'reform and opening up' policies, as the beginning of this process. In fact, international economic relations of the PRC date back to its foundation. If the international environment limited policy options before the late 1970s, it did not totally isolate China from the global marketplace. Two related themes shaped debates within China regarding which foreign economic policies should be adopted. The first theme was whether China should follow a Soviet-style command economy or a market economy, which was a question of socialism or capitalism in the eyes of some Chinese. The second theme was whether China should be economically self-sufficient or accept international economic interdependence. Much of the Chinese elite questioned whether the concept of comparative advantage was consistent with the Marxist approach. ${ }^{18}$ In the early 1950s, under both external and internal pressures, Chinese elites made a conscious decision to limit dependence on foreign economic interactions. ${ }^{19}$ The inwardly oriented development strategies until 1979 were primarily determined by the disagreement between Chinese elites over the best path to self-reliance. ${ }^{20}$ This delayed China's adoption of a more outwardly oriented regime, but economic interactions with the outside world expanded as elites gradually learned from their policy successes and failures. Finally, in December 1978 Deng won the battle with his motif 'practice is the only standard to judge truth' [shijian shi jianyan zhenli de weiyi biaozhun]. 'Reform and opening up' policies were launched.

The debates around these two themes continued after 1978, but increased interaction with the outside world brought in new ideas and knowledge about economic development and globalisation, infused by overseas trained intellectuals, foreign experts and institutions. When

\footnotetext{
${ }^{18}$ Stuart Harris, "Globalisation and China's Diplomacy: Structure and Process," in Working Paper (Canberra: Department of International Relations, Research School of Pacific and Asian Studies, Australian National University, 2002).

${ }^{19}$ Lawrence Reardon, The Reluctant Dragon: Crisis Cycles in Chinese Foreign Economic Policy (Seattle and London: University of Washington Press, 2002), 4-5. See also Dwight H. Perkins, "China's Economic Policy and Performance," in Cambridge History of China, ed. Roderick MacFarquhar and John K. Fairbank (Cambridge: Cambridge University Press, 2001), 488-90.

${ }^{20}$ Reardon, The Reluctant Dragon.
} 
Stuart Harris, Head of the Australian Department of Foreign Affairs and Trade (DFAT), visited China in 1984, a Chinese Vice Premier asked him to explain Ricardo's theory of comparative advantage ${ }^{21}$ Such inputs have played a prominent role in drawing up the reform blueprints for the Chinese leadership. Increased international interaction also brought economic, as well as political, benefits to various domestic actors, which has made China's liberalization an increasingly irreversible trend. Gradually the idea that trade was mutually beneficial, and not 'exploitative and immiserising' was accepted. ${ }^{22}$ The idea of economic interdependence was criticized by China in the United Nations (UN) in the mid 1980s, but was accepted as necessary and beneficial by the mid $1990 \mathrm{~s} .{ }^{23}$ The Chinese government has become more willing to bear costs associated with interdependence, for investment, overseas markets, technology, managerial skills and other resources. Enthusiasm and vigour are obvious in China's presentday international economic activities.

Opportunities and challenges abound in China's rise and internationalization both for other countries and for China itself. As a rapidly expanding economy, China is seeking access to markets as widely as possible, hunting globally for energy and resources to provide for its growing population and industrial needs, gradually increasing outward investment, and trying to write the rules governing international economic interactions. Targeting China for their economic expansion, other countries compete to occupy the seemingly insatiable and yet competitive Chinese domestic market, take pains to obtain licenses to invest in China, and try to convert China to international standard practices. Tensions exist between China's expansionist force and partial resistance to being a target of expansion, between reforming domestic institutions according to international standards and keeping the status quo for political and security reasons, and between complying with established international rules, and defying or revising them. Since the late 1990s, a notable feature of China's economic diplomacy has been its increasing activism in regional economic cooperation.

\footnotetext{
${ }^{21}$ Interview with Stuart Harris, 21 February 2008, Canberra.

${ }^{22}$ Stuart Harris, "China's Role in WTO and APEC," in China Rising: Nationalism and Interdependence, ed. David Goodman and Gerald Segal (London: Routledge, 1997).

${ }^{23}$ Harris, "Globalisation and China's Diplomacy."
} 


\section{China's regional reach}

China has been involved in regional forums and dialogues since the mid $1980 \mathrm{~s} .{ }^{24} \mathrm{As}$ regional economic cooperation in the West Pacific started among Asia Pacific countries,

China's regional reach started in the Asia Pacific, with a conservative and cautious attitude. It became a member of the APEC in 1991, and has given a clear voice at APEC annual summits, particularly as an Asian developing country. China has advocated unilateralism, voluntarism and flexibility as the APEC approach, and stressed technical and economic cooperation instead of market liberalization as the focus of APEC. During the Asian financial crisis, East Asian countries were disappointed with major developed countries and there was frustration that APEC did too little to help. The Bogor Declaration in 1994 set firm targets of trade liberalization for APEC members to reach by 2010 and 2020 depending on the development level of individual economies, but the APEC Leaders' Meeting at Kuala Lumpur in 1998 failed to push the agenda through an Early Voluntary Sectoral Liberalization initiative, because members could not achieve consensus on the early liberalization of the proposed sectors. ${ }^{25}$ Disappointment and pessimism thus led this Asia-Pacific forum to stumble to the backstage of regional economic cooperation, replaced by growing East Asian regionalism.

China seized the opportunities provided by the crisis to increase its influence in the region. When East Asian countries suffered from pressure exerted by the IMF or the US during the Crisis to carry out market reforms, China maintained the value of the yuan in a seemingly selfless manner, although depreciation would have better served the interests of Chinese exports. ${ }^{26}$ The Chinese delegation did not express immediate support for Japan's proposal of establishing an Asian Monetary Fund (AMF) in 1997, a regional multilateral financial arrangement equivalent to the IMF. The idea was dropped eventually because of opposition

\footnotetext{
${ }^{24}$ See Harris, "China's Role in WTO and APEC." Lawrence T. Woods, "Delicate Diplomatic Debuts: Chinese and Soviet Participation in the Pacific Economic Cooperation Conference," Pacific Affairs 63, no. 2 (Summer 1990).

${ }^{25}$ John Ravenhill, "APEC Adrift: Implications for Economic Regionalism in Asia and the Pacific", The Pacific Review 13, 2 (June 2000): 319-33. Ippei Yawazama and Robert Scollay, "Towards an Assessment of APEC Trade Liberalization and Facilitation", in APEC as an Institution: Multilateral Governance in the Asia-Pacific, edited by Richard E. Feinberg (Singapore: Institute of Southeast Asian Studies, 2003): $111-30$.

${ }^{26}$ Mengkui Wang, "Yazhou Jinrong Weiji yu Zhongguo [Asian Financial Crisis and China]," Qiushi [Seeking Truth] no. 21 (1998). Yong Wang, "Causes, Impacts of the Asian Financial Crisis and China's Measures: A Summary of the Symposium 'Asian Financial Crisis: Views from China and the US' Conference," Meiguo Yanjiu [American Studies], no. 3 (1998).
} 
from the US. However, when another form of regional financial cooperation - the Chiang Mai Initiative of bilateral swap arrangements - was proposed under the ASEAN +3 framework in 2000, China gave enthusiastic support.

To be sure, multi-track connections with ASEAN had been set up by China throughout the 1990s to enhance all-round bilateral diplomatic relations. China backed Malaysian Prime Minister Mahathir Mohamad's proposal of an East Asian Economic Group in 1991, although the idea was opposed by the US and the proposed grouping became merely a symbolic caucus in APEC. China has always firmly supported the 'ASEAN way' of dialogue and problem solving, and sought energetically to dispel ASEAN's concerns regarding the 'China threat'. Having demonstrated China's benign intentions towards ASEAN by keeping the value of the yuan stable during the 1997-98 financial crisis, Chinese Premier Zhu Rongji surprised the region and the world by proposing an FTA with ASEAN in Manila in 1999. The move was unprecedented in Chinese economic diplomacy, a very different approach to trade liberalization from that of APEC or WTO. To some observers, it was a diplomatic coup in competing with Japan for influence in Southeast Asia and for leadership in East Asia. To others, it was unthinkable that China would consider being party to any FTA — a legally-binding international economic arrangement, which would limit the flexibility and autonomy of China's policymaking, and would normally require faster liberalization of the Chinese economy than the WTO does. ${ }^{27}$

China's move triggered a response from other countries in the form of forging similar economic arrangements with ASEAN, Japan being the first, followed by the US (although initially for both these countries, their agreements were with individual ASEAN partners), India, South Korea, Australia and New Zealand, and most recently the EU. Most ASEAN states seem to have welcomed such a trend by actively engaging in FTA talks either collectively or individually, so as to balance amongst and gain leverage over major economic powers while maximizing their economic opportunities. As a result, the joining of major world economic powers in the FTA competition is weaving the economy of the Asia Pacific and the world into a complex net of bilateral preferential arrangements.

\footnotetext{
27 John Ravenhill, "The New Bilateralism in the Asia Pacific." Lijun Sheng, "China-ASEAN Free Trade Area: Origins, Developments and Strategic Motivations," ISEAS Working Paper: International Politics and Security Issues Series, no. 1 (2003).
} 
China's FTA with ASEAN has also attracted many other countries to come to China with FTA proposals, for fear of being disadvantaged against ASEAN products in the Chinese market or simply because they seek improved access to the world's most dynamic economy. Moreover, seeing that China does not reject proposals for preferential economic arrangements as it used to, many countries want to lock in favourable economic relations with China, beyond that guaranteed by the WTO. China is also forging FTAs with countries that it deems strategically important or economically valuable in almost every continent. As Table 1 shows, by May 2008, China has signed formal FTAs with ASEAN and Chile on trade in goods and in services, with New Zealand on trade in goods, services and investment, and with Pakistan on trade in goods. ${ }^{28}$ It is negotiating, studying the feasibility of, and considering many other FTAs. Amongst them, China proposed the FTAs with ASEAN, Brazil, Chile, the Gulf Cooperation Council, India, the Shanghai Cooperation Organisation (SCO), the South African Customs Union and the Northeast Asian FTA. The proposals with Brazil and India have been shelved due to the partner countries' lack of enthusiasm. The majority of China's FTAs have been initiated by other countries, and the Chinese government seems to enjoy being the demandeur in the negotiations.

Table 1 Current status of China's FTAs ${ }^{29}$

\begin{tabular}{|l|l|}
\hline Status & Countries / Regions \\
\hline Proposed & $\begin{array}{l}\text { Mercosur (South American Common Market), Shanghai } \\
\text { Cooperation Organization, }\end{array}$ \\
\hline Feasibility Study & Costa Rica, India, South Korea, Switzerland \\
\hline Under negotiation & $\begin{array}{l}\text { ASEAN on investment, Australia, Bolivia, Chile on investment, } \\
\text { the Gulf Cooperation Council, Iceland, Norway, Pakistan on } \\
\text { services, Peru, South Africa Customs Union }\end{array}$ \\
\hline Agreement on Trade in Goods & ASEAN, Chile, Pakistan \\
\hline $\begin{array}{l}\text { Agreement on Trade in Services } \\
\text { Services and Investment }\end{array}$ & ASEAN, Chile \\
\hline
\end{tabular}

\footnotetext{
${ }^{28}$ China has completed free trade agreements with Hong Kong and Macau. A Greater China FTA is under consideration encompassing these three economies and Taiwan. But they will not be considered as foreign economic policies in this study. Having said this, this study does not exclude the possibility of looking at China's experiences in the FTAs with Hong Kong and Macau because these may have helped China's move to the broader region.

${ }^{29}$ This table is created by the author based on news reports.

${ }^{30}$ The Shanghai Cooperation Organisation consists of Kazakhstan, Kyrgyzstan, Russia, Tajikistan, and Uzbekistan and China.
} 
Such proactive moves in China's economic diplomacy have caused concern on the part of some countries. On the one hand, they are afraid of being left out of the circles of partnerships delineated by China because they want a share of early access into China's voracious domestic market. On the other hand, they fear that if they participate, Chinese products could flood their domestic markets and destroy domestic industries.

The questions bothering policymakers and scholars are: why have China's regional economic cooperation policies taken the form that they did? How far, and in what manner will China extend its partnerships of regional economic cooperation? For instance, China was able to sign some agreements on bilateral free trade or financial cooperation (like the FTA with ASEAN and the CMI), while it has not been able to agree to some other proposed arrangements (like the FTA with Australia and the proposed Asian Monetary Fund). China's policies also vary across different sectors on one proposed agreement (for instance, the protection of agricultural interests but not strong insistence for the interest of export-oriented manufacturing sectors in the FTA negotiation with Australia), or across time and proposals on similar issues (for instance, agricultural liberalization in the FTA with ASEAN but protection with Australia). The answer lies in China's policymaking on regional economic cooperation, which demands focusing on decision-making within China. When one looks into China's domestic policymaking, a central question that arises is to what extent the Chinese government is constrained by domestic political-economic conditions when it tries to participate in regional economic cooperation. Answering this question helps to identify whether China can simply be treated as a unitary actor, in which the state acts purely in response to the international environment without heeding various domestic interests or ideas. The next section will briefly discuss the kind of constraints the Chinese government might have on its regional economic cooperation, to foreshadow the detailed analysis in the case-study chapters about what constraints existed and how they played out in China's policymaking. 


\section{Domestic Constraints}

The swiftness with which China struck some regional deals (such as the FTAs with ASEAN, Pakistan and Chile) is extraordinary, considering the long journeys that the EU, North America and others took to realize regionalism. As will be discussed in detail later in the thesis, a major obstacle came from the opposition of domestic industries that were threatened by import competition. Is it simply because China is a centralized, authoritative regime that there is nothing strong enough to stand in the way of the leadership's strategic pursuits in regional economic cooperation?

There is no doubt that there were political and strategic motivations behind some of China's regional approaches. For example, analysts point out that by forging an FTA with ASEAN, China aimed to allay ASEAN's concerns arising from China's WTO accession, to build up a peaceful strategic environment, as well as to compete with Japan for regional leadership, to hedge against the US and to marginalize Taiwan in East Asia. ${ }^{31}$ Moreover, to secure supply of energy and resources has been a prominent feature of China's latest FTA policies, such as those with Australia, Chile, the Gulf Cooperation Council, the South African Customs Union and the Shanghai Cooperation Organisation. However, even if those strategic objectives all exist, does the Chinese government have a free hand in pursuing them through regional economic cooperation? It might be true that the Chinese central government has more autonomy in decision-making at the national level than those of many democratic countries do. If one looks carefully at China's foreign economic policymaking, however, various domestic constraints have the potential to impede the Chinese government's participation in international economic cooperation.

First, problems in the domestic economy, not least the state-owned enterprises (SOEs) and the banking sector, loomed large in liberalization and had the potential to generate uncertainties or even a major crisis. The WTO entry has already caused severe competition and challenges for some Chinese domestic industries, and FTAs would impose additional strains by

\footnotetext{
${ }^{31}$ For example: Kwei-Bo Huang, "The China-ASEAN Free Trade Area: Background, Framework and Political Implications," in Peace Forum (Taiwan Research Institute: 2002). Lijun Sheng, "China-ASEAN Free Trade Area: Origins, Developments and Strategic Motivations," ISEAS Working Paper: International Politics and Security Issues Series, no. 1 (2003). Daojiong Zha, "The Politics of China-ASEAN Economic Relations: Assessing the Move toward a Free Trade Area," Asian Perspective 26, no. 4 (2002).
} 
requiring faster reduction of trade barriers. It is also questionable whether exposing the weak Chinese banking sector further to external financial fluctuations under regional financial arrangements would be welcomed by all.

Second, economic liberalization caused social and regional disparities in China, which was seen by many Chinese as the biggest threat to the regime's legitimacy. ${ }^{32}$ That was reflected in the rising incidence of protests by peasants and laid-off workers, and of ethnic unrest, as well as wide-spread resentment in the citizenry for poor social welfare, corruption and the increasing stratification of the society. These problems were likely to be intensified by FTAs, which would require the government to carry out more economic liberalization.

Third, among central policymakers, foreign economic policymaking was torn by the division between neo-conservatives (or 'neo-leftists') and liberals. ${ }^{33}$ They debated about over what pace, and how deep China should continue in its economic liberalization. This debate became louder on the issue of accession to the WTO and it continued over whether the commitments under the WTO had been a sell-out of China's national interest. The leadership had to balance between these two factions for political legitimacy, and had to design one from the various models for economic development to suit China.

There were also self-imposed constraints on a proactive approach to China's economic diplomacy. After the Tiananmen Square Incident in 1989, Deng set the principle of 'tao guang yang hui' [hide the sharpness while accumulating strength] and 'jue bu dang tou' [never take the lead] for diplomacy. ${ }^{34}$ Facing other countries' concern over a "China threat", the Chinese leadership reiterated that China would not seek to become a regional or global hegemon. As a result, Chinese foreign policy in general kept a low profile.

\footnotetext{
32 Shaogang Wang, "The Social and Political Implications of China's WTO Membership", Journal of Contemporary China 9, 25 (2000): 373-405. Fengxuan Xue and Dadao Lu eds., China's Regional Disparities: Issues and Policies (Huntington N.Y.: Nova Institute Press, 2001). Mathew D. Moneyhon, "Taming China's "Wild West": Ethnic Conflict in Xinjiang', Peace, Conflict, and Development: An Interdisciplinary Journal 5, 5 (2004): 2-23. Jessica Koch, "Economic Development and Ethnic Separatism in Western China: A New Model of Peripheral Nationalism”, Murdoch University Asia Research Centre Working Paper No. 134 (Aug. 2006), available online at http://wwwarc.murdoch.edu.au/wp/WP134.pdf.

${ }^{33}$ Feng Chen, "The Unfinished Battle in China: The Leftist Criticism of the Reform and the Third Thought Emancipation", The China Quarterly 158 (June 1999): 447-67. Pankaj Mishra, "China’s New Leftist", The New York Times, 15 October 2006.

${ }^{34}$ These are part of Deng's 'Sixteen-Character Principles' for diplomacy. Quansheng Zhao, Interpreting Chinese Foreign Policy: The Micro-Macro Linkage Approach (Hong Kong; New York: Oxford University Press, 1996), 53-54.
} 
Furthermore, from an economic view, for China, a large nation with global economic and political interests, taking an open, global approach to international economic cooperation is sensible and perhaps optimal for expanding its global economic interests. It is therefore reasonable that China pursued WTO membership and participated in APEC for broad international economic links. Even in 1997, foreign trade minister Wu Yi cautioned that regional economic groupings could evolve into fragmented trade blocs isolated by protectionism. ${ }^{35}$

Last but not the least, according to political economic theory, together with economic liberalization should come pluralisation in decision-making. Marketisation and opening of the economy mean that an increasing number of actors have a stake in foreign economic policy, and the state is increasingly dependent upon business and industrial interests to achieve national policy goals. However, as John Ravenhill noted, few studies have been made of the role of interest groups in the construction of the regional cooperation of East Asian countries, as most studies assume that these governments enjoy autonomy in the pursuit of foreign economic policies ${ }^{36}$ Nonetheless, all governments must respond to their own constituencies, especially in a country undergoing marketisation and liberalization.

Considering the domestic constraints on China's pursuit of regional economic cooperation, it is a question of to what extent the Chinese policymakers can negotiate between national strategic interests and domestic interests on the one hand, and among different domestic interests on the other. The dilemma has already been exemplified in the slow progress of China's FTA negotiation with Australia. As will be discussed in more detail in Chapter Two, there is a rich body of literature on the political economy of trade policy in developed countries, but a lack of research on the domestic politics of regional economic cooperation, even less on that in developing countries. There is a lot of analysis on China's regional diplomacy and some literature on China's foreign economic policymaking, but to date there has been no systematic study on China's policymaking of regional economic cooperation.

\footnotetext{
${ }^{35}$ Zheng Wu and Lu Xiao, "Warns of Protectionism Wu: Keep Regional Trade Open," China Daily, Apr. $11,1997$.

${ }^{36}$ Ravenhill, "A Three Bloc World?"
} 


\section{The study}

To address the issues mentioned above, this study explores the following questions:

What factors determine China's foreign economic policies on regional economic cooperation? Why have some interests or ideas prevailed in policymaking at the expense of others?

Answering the research question requires in-depth study of the policymaking processes in China. As there is little written information on the subject, most of the data for this study were collected through interviews with central and local government officials, think tanks and actors in the private sectors in China, as well as their counterparts in China's partner countries. ${ }^{37}$ As is common with most research based on interviews and surveys, there is a risk of bias and lack of reliability; therefore this study was conducted with caution and tried to confirm information from as many sources as possible.

The second chapter will review approaches and theories in the existing literature about foreign economic policymaking and relate them to what has been learned about the PRC's policymaking. After considering the complexity of foreign economic policymaking, particularly in the Chinese context, the study will adopt historical institutionalism as its conceptual framework and methodology. In other words, this study is concerned with how institutions structure the interactions among various interests and ideas to produce specific policy outcomes, and how institutions are developed in this process. That objective should be achieved through an inductive approach based on case studies. In particular, it proposes to pay attention to several features of policymaking institutions that may be decisive on policy outcomes: the degree of insulation of the central policymakers, the degree of collective action within each domestic interest group, and the degree of fragmentation of the state-level policymaking power. As institutional change is an important theme for historical institutionalism and more broadly, to studies of international relations and policymaking, this study proposes to highlight three

\footnotetext{
${ }^{37}$ For a list of institutions interviewed and the number of interviewees for this study, see "Appendix: List of Affiliation of Interviewees and Number of Interviewees". Interviews with government officials were either arranged through contacts or through opportunities of policy meetings that involve officials, business people and academics.
} 
sources for institutional change: institutional learning, the emergence of a new policy area, and change in the major agency.

The following three chapters will each detail and analyze one case of China's policymaking on regional economic cooperation: the China-ASEAN FTA (CAFTA), the Australia-China FTA (AUCFTA) and East Asian financial cooperation. The three cases are representative and important in China's regional economic cooperation. The CAFTA was the first free trade agreement proposed by China to another country and the first to be signed and implemented. As discussed above, it is one of the most significant developments in the history of Chinese economic diplomacy and participation in regionalism in the Asia Pacific. The AUCFTA is the first free trade arrangement negotiated by China with a major developed country. China's foreign economic policymaking institutions have changed from the time of the CAFTA; so have policy inputs representing various interests or ideas into the policymaking process. The combination of these factors is in turn reflected in China's different policy and negotiation behaviour from those on the CAFTA. As for East Asian financial cooperation (including the AMF, the CMI and initiatives to deepen financial and monetary cooperation), China has held varied positions, ranging from stark opposition, to ambiguity, to enthusiastic support. A comparison between policymaking in those financial initiatives, and between trade and finance shows not only China's changing strategies in economic diplomacy, but also that the difference in policymaking institutions leads to different policy decisions, even when the state's strategic motivation is similar behind foreign economic policies.

The last chapter will compare the three cases to draw out the decisive factors in China's policymaking on regional economic cooperation. In a nutshell, the study finds that although preferences - consisting of interests and ideas - do matter in policy making, institutions play a crucial role in structuring interactions between policy preferences and deciding which preferences prevail over others. The chapter will summarise the findings from the previous chapters, and conduct a comparative analysis between the cases, to draw conclusions on whether the several features of policymaking institutions as proposed in Chapter Two have been crucial in determining policy outcomes. It will also summarise the sources that have propelled the creation and transformation of institutions during China's participation in regional economic 
cooperation, despite the tendency of institutions to resist change because of embedded interests or ideas.

This study aims to fill a gap at the nexus between the literature on China's foreign economic policy making and the works on regional economic cooperation. More broadly, it contributes to the understanding of countries undergoing liberalization, foreign economic policymaking and international cooperation. 


\section{Chapter 2 Conceptualizing Foreign Economic Policymaking in the Chinese Context}

Theories of political economy and international relations ask several enduring questions. Why do states cooperate, even if cooperation requires them to give up part of state autonomy and to bear the costs of policy adjustments? Which factor in policy making weighs most on policy decision? How do institutions develop and how do they shape decision-making? As to foreign economic policy, many economists question why states do not fully liberalize their economy, which is supposed to enhance their overall welfare, whereas political scientists are intrigued by how the governments can open up their domestic markets without being captured by domestic protectionist groups. To both disciplines, several questions need to be answered in order to understand economic liberalization: how does a state reach a specific point between the two extremes of liberalization and protection? How does a state negotiate and choose among a myriad of national and domestic, political and economic interests and ideas? And in recent decades, is regionalism' a stepping stone or stumbling block for global economic liberalization?

Many answers to those important questions lie in the making of foreign economic policy because behaviours are best understood by tracing their sources in decision making. This thesis does not claim to answer all the above questions, but the study of policy making on regional economic cooperation stands at the shared area of inquiry by literatures on foreign economic policy making in particular and state policy making in general, international cooperation, and regionalism. It is the triangular international-regional-domestic linkages and the intertwining of strategic-political issues with economic issues that make the policy making on regional economic cooperation an extremely dynamic topic. International and domestic actors have influence on policy making, although the final authority of national policy decision belongs to the state.

\footnotetext{
${ }^{1}$ For the purpose of this thesis, I follow the WTO in understanding regionalism as any inter-governmental economic cooperation that is not unilateral or global. See John Ravenhill, "Regionalism," in Global Political Economy, ed. John Ravenhill (New York: Oxford University Press, 2005), 116-47. This thesis will use regionalism and regional economic cooperation inter-changeably. The cases in this thesis include China's trade cooperation with ASEAN and Australia, as well as financial cooperation in East Asia. ASEAN belongs to East Asia, the core of China's concentric map of regional cooperation, while Australia belongs to what the Chinese government considers to be an outer circle- the Asia Pacific. MOFCOM holds that regional economic cooperation has superseded the constraints of geography. See MOFCOM, "Vice Minister Yi Xiaozhun Talks about China's Choices and Achievements in Regional Economic Cooperation", 29 May 2007, http://yixiaozhun.mofcom.gov.cn/aarticle/speeches/200705/20070504725234.html.
} 
Studying China's foreign economic policymaking is to conceptualize foreign economic policymaking in the Chinese context, to see how existing theories of foreign economic policymaking can help with the study of China, and how Chinese experiences can enrich the knowledge of foreign economic policymaking. The Chinese context is of a developing country with a large economy, a political-economic system in transition, and one that is certainly imbued with unique Chinese history and culture.

As will be discussed in more detail in this chapter, this study attempts to fill in the overlapping gap among literatures of foreign economic policymaking, regionalism and China studies. Most existing theories of foreign economic policymaking are based on democratic and developed countries, with only a few exceptions on non-democratic and developing countries. In international political economy, many studies attribute variations in trade policies and international economic cooperation to international factors, especially the global distribution of capabilities and international institutions; fewer studies have examined the domestic sources of international cooperation. ${ }^{2}$ Reflected in the studies of regionalism, there is a heated international-systemic discussion, but less is available on the domestic politics of regional economic cooperation, and even less on that in Asia Pacific. In China studies, there is a lot of analysis on China's foreign policy, foreign economic policy and regional diplomacy at the international level based on various theoretical premises of international relations (particularly realism and to a lesser extent constructivism), but information on the domestic policymaking process is very limited. A study of domestic policymaking may provide a way of integrating the emphases of different theoretical schools on material interests, ideational factors and domestic politics in the explanation of a country's international relations. Although there are some works on Chinese foreign policy making and Chinese policymaking in general, to date there have been very few attempts to explore the intricacies of Chinese foreign economic policymaking. Although the former literature provides useful insights to the latter, the separate features of foreign economic policymaking deserve more attention. Some studies on China's policymaking

\footnotetext{
${ }^{2}$ Helen V. Milner, B. Peter Rosendorff, and Edward D. Mansfield, "International Trade and Domestic Politics: The Domestic Sources of International Trade Agreements and Institutions," in The Impact of International Law on International Cooperation: Theoretical Perspectives, ed. Eyal Benvenisti and Moshe Hirsch (New York: Cambridge University Press, 2004).
} 
have dealt with China's pre-reform formal state structure and elite ideological struggles; ${ }^{3}$ some with policymaking during economic reform, of which liberalization is a major part; ${ }^{4}$ and others with China's accession into the WTO. ${ }^{5}$ To date, there is no study on China's domestic policymaking towards regional economic cooperation.

\section{The level of Analysis}

Studying foreign economic policymaking is not complete without taking into

consideration factors at both international and domestic levels. This thesis agrees with the twolevel argument of Robert Putnam that international negotiations are games between negotiators constrained by domestic constituencies in both countries. ${ }^{6}$ The focus of the study, however, is not to explain the result of international negotiation, but to understand the policy stance a country adopts at the negotiation table.

This study will focus primarily on the domestic level because only after obtaining a detailed account of the domestic policymaking process can an accurate view be achieved on how various factors from both international and domestic levels interact with each other to produce policy outcomes by affecting the decision of policymakers. As structuralists have

\footnotetext{
${ }^{3}$ For instance, A. Doak Barnett, Cadres, Bureaucracy, and Political Power in Communist China (New York: Columbia University Press, 1967). Lawrence Reardon, The Reluctant Dragon: Crisis Cycles in Chinese Foreign Economic Policy (Seattle and London: University of Washington Press, 2002).

${ }^{4}$ For example, Susan L. Shirk, China, Fragile Superpower : How China's Internal Politics Could Derail Its Peaceful Rise (New York: Oxford University Press, 2007); Susan L. Shirk, How China Opened Its Door: The Political Success of the PRC's Foreign Trade and Investment Reforms, Integrating National Economies (Washington, D.C.: Brookings Institution, 1994). Harold K. Jacobson and Michel Oksenberg, China's Participation in the IMF, the World Bank, and GATT: Toward a Global Economic Order (Ann Arbor: The University of Michigan Press, 1990). Nicholas R. Lardy, China's Unfinished Economic Revolution (Washington, D.C.: Brookings Institution Press, 1998). Kenneth Lieberthal and David M. Lampton, Bureaucracy, Politics, and Decision Making in Post-Mao China, Studies on China; 14 (Berkeley: University of California Press, 1992); Ning Lu, The Dynamics of Foreign-Policy

Decisionmaking in China, 2nd ed. (Boulder, Colo.: Westview Press, 2000); Thomas W. Robinson and David L. Shambaugh, Chinese Foreign Policy: Theory and Practice (Oxford and New York: Clarendon Press; Oxford University Press, 1994).

${ }^{5}$ Joseph Fewsmith, "China and the WTO: Politics Behind the Agreement," NBR Analysis 10, no. 5 (December 1999): 23-39. Bin Sheng, Zhongguo Duiwai Maoyi Zhengce De Zhengzhi Jingji Fenxi [the Political Economy of China's Foreign Trade Policies] (Shanghai: Shanghai Sanlian, 2002), 316-35. Hui Feng, The Politics of China's Accession to the World Trade Organisation: The Dragon Goes Global (London and New York: Routledge, 2006). Jacobson and Oksenberg, China's Participation in the IMF, the World Bank, and GATT. Margaret M. Pearson, "The Case of China's Accession to GATT/WTO," in The Making of Chinese Foreign and Security Policy in the Era of Reform, 1978-2000, ed. David M. Lampton (Stanford: Stanford University Press, 2001), 337-70. Shaoguang Wang, "The Social and Political Implications of China's WTO Membership," Journal of Contemporary China 9, no. 25 (2000): 373-405. Hung-Gay Fung, Changhong Pei, and Kevin H. Zhang., eds., China and the Challenge of Economic Globalization: The Impact of WTO Membership (Armonk, New York: M.E. Sharpe, 2006); Heike Holbig and Robert Ash, eds., China's Accession to the World Trade Organization: National and International Perspectives (New York: RoutledgeCurzon, 2002).

${ }^{6}$ Robert D. Putnam, "Diplomacy and Domestic Politics: The Logic of Two-Level Games," International Organization 42, no. 3 (Summer 1988): 427-60.
} 
conceded, international systemic analysis lacks a conception of process, or an explanation of how the constraints or interests derived from the international economic structure are transformed into decisions or political strategies within particular countries. ${ }^{7}$ The international role a state plays cannot be predicted simply by calculating its material endowments, because how these endowments translate into actual foreign economic policies is not straightforward or deterministic - there is always scope for creative leaders to fashion independent policies, although within an environment that inevitably imposes some constraints.

International factors have an impact on state policies by influencing the ideas or interests held by domestic actors who are involved or have a say in the policymaking process. James Roseneau's 'linkage politics' model is notable because it studies domestic foreign policy making while incorporating the influence of international factors with ideational or material linkages between the two levels. ${ }^{8}$ Quansheng Zhao's study of China's foreign policy making emphasizes the 'macro-micro' linkages as well. ${ }^{9}$ However, this thesis does not use the international-domestic linkages as the unit of analysis, but actors' policy preferences and policymaking institutions, as will be discussed later in this chapter.

One way the international system influences state behaviour is by shaping the country's perceptions of its 'national interests', especially through the eyes of policymakers. Another way is by influencing domestic interests. Domestic actors who have a stake in the country's international economic interactions are usually the most articulate proponents of their interests in the policymaking process, either bluntly on behalf of themselves or by claiming they represent the national interest. The political leadership sometimes uses internationally embedded interests to resist domestic demands. ${ }^{10}$ Either way, the international factors influence national policymaking through domestic agents.

\footnotetext{
${ }^{7}$ David Lake, "International Economic Structures and American Foreign Economic Policy, 1887-1934," World Politics 35 (July 1983): 517-43.

${ }^{8}$ James N. Roseneau, ed., Linkage Politics: Essays on the Convergence of National and International Systems (New York, London: The Free Press, Collier-MacMillan, 1974).

${ }^{9}$ Quansheng Zhao, Interpreting Chinese Foreign Policy: The Micro-Macro Linkage Approach (Hong Kong; New York: Oxford University Press, 1996).

${ }^{10}$ Putnam, "Diplomacy and Domestic Politics: The Logic of Two-Level Games."
} 
Therefore, the study will focus at the domestic level, but incorporate various interests and ideas with domestic or international origins to see how they interacted with each other in the domestic policymaking process and influenced policy decisions.

\section{Interests, ideas and institutions of foreign economic policymaking}

The literature of foreign economic policymaking (and in decision making in general) has evolved around three dimensions - interests, ideas and institutions. There is a debate on which of the three matters most. Because these three dimensions essentially constitute the key factors in any policymaking process, this section will review how they are perceived in that literature and in the studies of China's policymaking, for two purposes. The first is to scope which kind of factors should be taken into consideration when one studies the domestic policymaking of regional economic cooperation. The second is to identify the theoretical and empirical loopholes in the existing literature, and to adopt a comprehensive and systematic conceptual framework which will help to establish the linkages among the factors in the empirical study of China.

In a nutshell, each of the three dimensions encompasses some of the debates in international political economy and international relations as mentioned at the beginning of this chapter. The content of interests includes both national strategic interests and economic interests (involved in regional economic cooperation in this study), and 'self-interests' of domestic actors - their economic benefits and (for individuals) their career goals. The role of ideas is most prominent when they influence actors' definition of their interests. China's regional economic cooperation is influenced by ideas about regional and global economic cooperation, modes of industrialization and liberalization, and China's identity in the region and in the world, amongst others. The debate in the literature on the relationship between interests and ideas indicates that there is no definite demarcation between the two, ${ }^{11}$ but they can both be treated as policy preferences in policymaking. The preferences interact - convert and compete - with each other in a certain institutional setting in the process of producing the final decision. Joining in

\footnotetext{
11 Frank Trentmann, "Political Culture and Political Economy: Interest, Ideology and Free Trade," Review of International Political Economy 5, no. 2 (Summer 1998): 217-51. Judith Goldstein, "The Impact of Ideas on Trade Policy: The Origins of U.S. Agricultural and Manufacturing Policies," International Organization 43, no. 1 (Winter 1989). Mark M. Blyth, "Any More Bright Ideas? The Ideational Turn of Comparative Political Economy", Comparative Politics 29, 2 (Jan., 1997): 229-50.
} 
the debate among the approaches emphasizing interests, ideas and institutions in the study of foreign economic policymaking, this study supports the argument that the role of institutions is overarching. Institutions not only distribute power among policy preferences, but also influence actors' definition of preferences. In this way this study strives to answer the call in the policymaking literature for a synthesized approach of preferences and institutions, through the case studies of China's foreign economic policymaking on regional economic cooperation.

\subsection{Interests in foreign economic policymaking}

Before looking into the decision-making process of Chinese foreign economic policies, it is necessary to know what types of interests are likely to be at stake in these policies and which actors represent them, in order to further analyze how these interests compete with each other to become a definitive part of the 'national interest', and the priority among the policymakers' choices of national policies.

Economic interests are an important objective of foreign economic policies. What makes the decision making on foreign economic policies different from that on domestic economic policies is that non-economic interests, such as state political and strategic interests, are more likely to be involved in the former and are often in conflict with economic interests in terms of policy implications. Similar to foreign policy, foreign economic policy is supposed to take the 'national interest' as the ultimate goal — although 'national interest' is a complex concept as will be discussed later - and hence the privileged role often enjoyed by some central governmental agencies in decision making. Foreign economic policy, however, is more likely than foreign policy to have an immediate impact on domestic welfare, which means that it is more likely to generate domestic pressures on state policymaking. It is the international-state-domestic linkage of interests and the complication of non-economic issues that make foreign economic policymaking a particularly dynamic topic.

Approaches focusing on interests perceive foreign economic policymaking in broadly two ways. One way sees foreign economic policymaking as the passive balancing act of policymakers in reaction to pressures from domestic interest groups and the wide electorate in order to win elections. Put it in another way, foreign economic policies are the result of 
competition among domestic interest groups (or policy coalitions, depending on the type of the political system) to influence policymakers in pursuit of self-interests. The other perspective treats foreign economic policymaking as rational calculation of the state as a unitary actor in pursuit of national interests. As will be discussed later, these two approaches are helpful for identifying various interests, but foreign economic policies involve a wide spectrum of economic and political interests at both domestic and state levels, and some of these interests are not derived from material calculations; therefore they all need to be incorporated into one analytical framework so as to study their interactions in policymaking.

\subsubsection{Domestic-level self-interests and Chinese domestic interests}

As Edward Mansfield and Helen Milner pointed out, "there is a lack of empirical evidence indicating which domestic groups support regional trade agreements, whose interests these agreements serve, and why particular groups prefer regional to multilateral trade liberalization... [and] we know little about whether, once in place, regional arrangements foster domestic support for broader, multilateral trade liberalization or whether they undermine such support." ${ }^{12}$ Besides, the literature on foreign economic policymaking is mostly based on practices in Western democratic countries, and emphasizes pressures from domestic societal interests on the state policymakers; therefore "research on the preferences of social groups entering politics in the post-Communist world would be a valuable addition to the literature on the politics of economic reform." ${ }^{, 13}$ This section surveys the literature on domestic interests in foreign economic policymaking, and considers which domestic groups have a stake in China's regional economic cooperation as well as what preferences they may have.

Domestic-level self-interests refer to interests held by actors within the domestic context, although the actors may be local or foreign (such as the subsidiaries of multinational corporations). Domestic self-interests in foreign economic policy include economic benefits of domestic groups clustered in industries, classes and/or regions, the welfare of the wide

\footnotetext{
${ }^{12}$ Edward Mansfield and Helen V. Milner, "The New Wave of Regionalism," International Organization 53, no. 3 (1999): 589-627.

${ }^{13}$ Timothy Frye and Edward D. Mansfield, "Fragmenting Protection: The Political Economy of Trade Policy in the Post-Communist World," British Journal of Political Science 33 (Oct. 2003): 635-57.
} 
electorate (or consumers), and career objectives of businesspeople and government officials.

Overall it is necessary to know the distribution and redistribution of domestic interests when a certain policy is adopted, before analyzing how they influence policymaking.

\section{Class and industry}

Economic analysis is widely used as a first step of mapping the policy preferences of different groups in the domestic economy. An important determinant of domestic trade policy coalitions suggested by trade specialists is "factor specificity", defined as the costliness with which factors move from their current use to an alternative one ${ }^{14}$ It coincides with different stages of industrialization and different amounts of regulation. ${ }^{15}$ The Heckscher-Ohlin model applies to low factor specificity, and predicts that trade policy coalitions will form along factor or class lines. ${ }^{16}$ Owners of abundant factors will favour free trade, while owners of scarce factors will be protectionist. Similarly, on the issue of foreign investments, allowing more inward flows of capital into one sector will upgrade competition and lower real return for local investors in this sector. This model is supported by Dani Rodrik and Helen Milner's explanation of developing countries' rush to free trade in the 1980s: the median voter in developing countries belongs to the labours' class; because labour is the abundant factor of such countries, this voter will support trade liberalization. ${ }^{17}$ In China, the HO model would predict that domestic owners of capital should oppose free trade for fear of competition from foreign capital. Because unskilled labour is abundant in China, including farmers and workers, they should support free trade. The question here is whether policy coalition can be built within the same socio-economic class across industries in China. Class coalition is rarely seen, if ever, in China

\footnotetext{
${ }^{14}$ James E. Alt and Michael J. Gilligan Jeffry Frieden, Dani Rodrik, and Ronald Rogowski, "The Political Economy of International Trade: Enduring Puzzles and an Agenda for Inquiry," Comparative Political Studies 29, no. 6 (1996): 689-717.

${ }^{15}$ Michael J. Hiscox, "Class Versus Industry Cleavages: Inter-Industry Factor Mobility and the Politics of Trade," International Organization 55 (Winter 2001): 1-46.

${ }^{16}$ The HO model is often used to explain inter-country differences in factor endowments under perfect competition.

${ }^{17}$ Dani Rodrik, "The Rush to Free Trade in the Developing World: Why So Late? Why Now? Will It Last?" in Voting for Reform: Democracy, Political Liberalization, and Economic Adjustment, ed. H. Stephen and S. Webb (New York: Oxford University Press, 1994), 61-88. Helen V. Milner, "Why the Move to Free Trade: Democracy and Trade Policy in the Developing Countries," International Organization 59 (Winter 2005): 107-43. Also see, Kjell Hausken, Thomas Plumper, and Gerald Schneider, "The Trilemma of the Protectionist Autocrat: An Assessment of the Political Determinants of Foreign Economic Liberalization," (Stavanger, Norway: School of Economics, University of Stavanger: 2002).
} 
after the Cultural Revolution, and even less over the issue of foreign economic policies. In China's process of joining the WTO, no policy coalition was formed either between farmers and workers or within each group. Protests by workers against income inequality, unemployment and lack of social security have come from particular industries. Similarly, in agriculture, protest has not come from farmers or farmers' unions but from the Ministry of Agriculture: in representing the sector, it was one of the staunchest domestic actors that opposed China's accession into the WTO. Peasant riots have targeted heavy agricultural taxes and loss of land in particular, rather than attempting to unite with owners of other forms of labour. As will be discussed more in later chapters, the similar lack of class coalition is evident in China's policymaking on free trade agreements. Domestic investors in industries producing labourintensive exports, however, are supporters of economic liberalization. ${ }^{18}$ This suggests the policy preferences of capital owners do not simply depend on which class they belong to but which markets they produce for.

In contrast to the $\mathrm{HO}$ model, the Ricardo-Viner model is applied to countries of high factor specificity, and predicts trade policy coalitions will form along the lines of exporting versus import-competing industries. A lot of evidence in the developed countries supports this delineation, and the focus of industries' lobbying has been helpful to analysis of the domestic politics of trade policy. Applied to China in the late 1990s, the RV model correctly predicts the textile industry would support China's accession into the WTO while the automobile industry would not, because the textile industry had comparative advantage in trade with most countries and would be largely exporting, whereas the automobile industry, not competitive in overseas markets, would have to compete with foreign products in the domestic market.

Which model then is more applicable to China, HO or RV? Is it easy or difficult for factors of production to move in the Chinese economy? Having grown out of a planned economy into a more marketized one, the overall factor specificity in China has decreased substantially thanks to economic regulation reforms since 1978 . However, extensive state intervention still covers most economic activities in China. Perhaps both models have some

\footnotetext{
${ }^{18}$ Feng, The Dragon Goes Global. Wang, "The Social and Political Implications of China's WTO Membership." Yong Wang, "China's Domestic WTO Debate," The China Business Review 27, no. 1 (Jan/Feb 2000): 54-58.
} 
explanatory power because many industries develop according to the comparative advantage of a country in factor endowments. In other words, exporting industries are those using abundant factors in a country (unless they are subsidized by the state to promote export for non-economic reasons), and import-competing industries are those using relatively scarce factors. A major source of China's economic growth during trade liberalization has been the exporting of labourintensive products. In agriculture, China's has comparative advantage in labour-intensive products but disadvantage in land-intensive products; however, the Chinese agricultural sector has only one seat at the state-level policy coordination meetings in China's foreign economic policymaking. So do other industries. Although an industrial ministry may represent sectors of both comparative advantage and those of disadvantage, they may have to choose a position between support and opposition in the inter-ministerial policy discussions on a free trade agreement. In China, domestic interests cannot influence the policymakers directly. Their interests are distilled through government agencies. This process often involves sacrificing the interests of some sectors.

Therefore, which kind of policy coalition is likely to form in a country not only depends on economic grounds but also on the political and institutional environments. As will be discussed in detail later, institutions are decisive in determining the forms that policy coalitions will take, and their influence on central policymakers, by affecting the degree of collective action in each group and the distribution of power among them. The main form of domestic interest 'lobbying' in China is that industries express their interests and try to influence government decisions through the ministries directly in charge. ${ }^{19}$ From the assertions of various industrial ministries, a fairly clear story can be told about competing industrial interests over China's regional economic cooperation. Based on the above considerations, the Ricardo-Viner model may be more useful to scope the different interests of Chinese domestic groups, especially those of import-competing and export-oriented industries.

\footnotetext{
${ }^{19}$ See for example, Scott Kennedy, The Business of Lobbying in China (Cambridge, Mass.: Harvard University Press, 2005).
} 


\section{Local governments}

The factor specificity models provide a useful starting point in analysing which domestic class or industries favour liberal foreign trade and investment policies and which not. They do not directly apply to other sources of economic division, such as geographical, ethnic or familial ones. In democracies, sub-national interests are represented by senators or congressmen at the legislature; the movement of factors is freer than in many authoritarian or developing countries. Therefore existing theories have not focused on the interests of local governments in particular but instead focused on the lobby groups and the lawmakers. In China, however, the independent power of the legislature is still limited. Apart from the inter-industrial division, inter-regional division is a major feature of the fragmented Chinese economy, and decentralization of foreign economic policymaking power has been noted in various studies of the PRC's reforms. ${ }^{20}$ Therefore, it is necessary to know the interests of local governments. Economic benefits of foreign economic policy for the provinces are largely determined by the main industries within their territories, constrained by natural endowments and government policies, as well as their attractiveness to foreign direct investments. Similar to other federal systems, local revenue is very important for the careers of Chinese local government officials; therefore local protectionism is noticeable during China's transition towards a market economy. ${ }^{21} \mathrm{An}$ international trade agreement can be a double-edged sword for local governments. On the one hand, it forces them to face more foreign competition and to carry out reforms demanded by the central government. On the other hand, it may provide local governments with opportunities to undertake activities other than their usual roles. ${ }^{22}$ For instance, some provinces of China

\footnotetext{
${ }^{20}$ Shaun Breslin, China and the Global Political Economy (New York, N.Y.: Palgrave Macmillan, 2007), 61-70. Peter T.Y. Cheung, Jae Ho Chung, and Zhimin Lin, eds., Provincial Strategies of Economic Reform in Post-Mao China (Armonk and London: M. E. Sharpe, 1998). Peter T.Y. Cheung and James T.H. Tang, "The External Relations of China's Provinces," in The Making of Chinese Foreign and Security Policy in the Era of Reform, 1978-2000, ed. David M. Lampton (Stanford: Stanford University Press, 2001), 91-120. Gabriella Montinola, Yingyi Qian, and Barry R. Weingast, "Federalism, Chinese Style: The Political Basis for Economic Success," World Politics 48, no. 1 (1996): 50-81. Shirk, How China Opened Its Door.

${ }^{21}$ Montinola, Qian, and Weingast, "Federalism, Chinese Style: The Political Basis for Economic Success." Shirk, How China Opened Its Door, 34-44. Tony Saich, Governance and Politics of China, 2nd ed. (Basingstoke, Hampshire [UK] ; New York: Palgrave Macmillan, 2004), 155-70.

${ }^{22}$ Andrew Mertha and Robert Pahre, "Patently Misleading: Partial Implementation and Bargaining Leverage in Sino-American Negotiations on Intellectual Property Rights," International Organization 59 (Summer 2005): 695-729.
} 
bordering Southeast Asia have developed border trade zones with neighbouring countries while dealing with competition from imported ASEAN agricultural products.

\section{Intra-industry trade}

The factor specificity models do not say much about intra-industry trade either. Because the factor specificity models are based on comparative advantage, they predict that regional economic cooperation is likely to happen between countries with different endowments (or 'complementary' economies), and not likely between countries with similar endowments (or ‘competitive' economies). In fact, a lot of regional economic cooperation has been achieved between countries of similar economic structures. Regional economic cooperation within geographical affinity is demanded by intra-industry trade or fragmented production and firms that require economies of scale to reduce transaction costs and uncertainty, and to enlarge the 'home' market. At the same time, regionalism facilitates the growth of those types of production networks once cooperation is decided between the states. ${ }^{23}$

In short, questions remain in the factor specificity models about how local governments balance challenges and opportunities in policymaking and how the central government reacts, as well as whether domestic interests are different in regional economic cooperation within geographical affinity and that without (for instance, between the China-ASEAN FTA and the proposed Australia-China FTA).

\section{Career goals}

Other domestic self-interests coexist with economic interests. One important goal of politicians, government officials and businesspeople is to maintain or enhance their positions. The career of businesspeople is usually a reflection of the performance of their businesses; therefore their interests should be in line with the sectoral interests discussed above. Here I will focus on the career goals of politicians and officials. Government officials sometimes form patron-client relationship with domestic economic sectors in the policymaking process, and

\footnotetext{
${ }^{23}$ Shaun Breslin and Richard Higgott, "Studying Regions: Learning from the Old, Constructing the New," New Political Economy 5, no. 3 (2000). Kerry A. Chase, "Economic Interests and Regional Trading Arrangements: The Case of NAFTA," International Organization 57 (Winter 2003): 137-74. Ravenhill, "Regionalism."
} 
sometimes act on behalf of their own political needs. The 'bureaucratic politics' approach framed by Graham Allison captures bargaining and 'log-rolling' between individuals in government bureaucracies - officials make decisions based on calculation of individual interests and negotiate conditions with each other. ${ }^{24}$ His 'rational choice' model also includes career goals as a major payoff for bureaucrats, apart from accumulation of personal wealth. In democracies, legislators are defenders of the benefits of their constituency so as to remain elected. In China, where the Communist Party still retains the power in personnel appointment and promotion, the cadres in the state ministries and local governments need to seek an intricate balance between protecting the benefits of the area they are in charge so as to generate profits and revenue in part as their credits for promotion, and showing a pleasant degree of compliance to the leaders.

To be sure, China cannot be taken for granted simply as a unitary authoritarian state anymore. The analytical task in examining the domestic interests in China's policymaking on regional economic cooperation is to identify different industrial and local interests with regard to particular policy initiatives, especially which are the import-competing and export industries, how they are geographically distributed and who represent them. The next question is how they participate in the policymaking process and whose interest the government will choose to accommodate. As Witold Henisz and Mansfield point out, approaches that stress the importance of interest groups in shaping trade policy usually give short shrift to the domestic political institutions that filter demands made by these groups and set policy. ${ }^{25}$ As will be argued later, the answer lies largely in the policymaking institutions.

\subsubsection{State-level interests and China's national interest}

While domestic groups compete to realize their own interests through national policies, the state's central policymakers can still have some room for decision-making independently of societal pressures. They are important players in the policymaking process, and are supposed to

\footnotetext{
${ }^{24}$ Graham T. Allison and Philip Zelikow, Essence of Decision: Explaining the Cuban Missile Crisis, 2nd ed. (New York: Longman, 1999).

${ }^{25}$ Witold J. Henisz and Edward D. Mansfield, "Votes and Vetoes: The Political Determinants of Commercial Openness," International Studies Quarterly 50 (2006): 189-211.
} 
pursue 'the national interest' as the paramount objective of foreign economic policy. Pinpointed in Allison's 'rational actor' model ${ }^{26}$ this approach implicitly or explicitly assumes the logic of rational choice. But unlike the rational choice literature, the focus is not on the career goals of the bureaucrat or politician but on the possibility that actors are motivated primarily by a vision of the national interest. Most studies on China's foreign policy and foreign economic policy are state-centred, particularly those on China's regional economic cooperation. That is understandable because the Chinese central government appears to have more autonomy in decision-making compared to most democratic countries. However, even state institutions that assume the paramount position in national policymaking may be driven by particularistic interests or informed by certain ideas.

State policymakers consider a wider range of issues concerning national interests than non-state domestic groups do. Foreign economic policy is sometimes an instrument the state uses to pursue international strategic and political goals. Richard Baldwin calls it 'economic statecraft'-using foreign economic policies (both carrots and sticks) to achieve foreign policy goals. These motivations are likely to figure prominently in regional economic cooperation. Various non-economic explanations of why a state pursues regional economic cooperation exist: to pursue regional leadership, sometimes hedging against its strategic competitors in the region; to strengthen strategic ties with and increase influence on partner countries by increasing economic inter-dependence; and for individual countries to have a stronger voice as a group in global debates, so on and so forth. ${ }^{27}$ China's motivations to establish an ASEAN-China Free Trade Area (CAFTA), for example, are asserted in the literature to include: to alleviate ASEAN's perception of the "China threat" and strengthen political relations with ASEAN for a peaceful neighbourhood; to compete with Japan for East Asian leadership; to hedge against American influence in Southeast Asia and Asia Pacific; and to constrain Taiwan's presence in regional affairs by alienating ASEAN from Taiwan. ${ }^{28}$

\footnotetext{
${ }^{26}$ Allison, Essence of Decision.

${ }^{27}$ See Ravenhill, "Regionalism."

${ }^{28}$ For example: Kwei-Bo Huang, "The China-ASEAN Free Trade Area: Background, Framework and Political Implications," in Peace Forum (Taiwan Research Institute: 2002), available online at: http://www.dsis.org.tw/peaceforum/papers/2002-02/APE0202001e.pdf, accessed on 4 March 2008. Lijun Sheng, "China-ASEAN Free Trade Area: Origins, Developments and Strategic Motivations," ISEAS Working Paper: International Politics and Security Issues Series, no. 1 2003). Daojiong Zha, "The
} 
The national interests in foreign economic policy can be both domestically and internationally oriented. China's foreign economic policy reforms since 1978 are widely believed to be two mutually enhancing and intertwining processes: expanding China's international economic relations and propelling domestic reforms. At the international level, international economic cooperation reduces costs and uncertainties in transactions. The proliferation of regionalism is largely triggered by the fear of countries being excluded from their markets that entered into preferential trade agreements with other countries. Big countries push a smaller country into economic cooperation in order to exploit its economic advantages, especially a bigger market size for its products that are over-supplied domestically but not globally competitive, and move their production to the small country so that the big country can climb to a higher position in the production chain. The international objective of a country's foreign economic policy can also be its grand global strategy. Jeffry Frieden argues that the objective of the inter-war American foreign-policy bureaucracy was to reorganize the world's political economy. ${ }^{29}$ Small countries seek economic integration in order to enlarge their 'domestic' market, if the rules of origin are not restrictive. That makes their economies more attractive for external investors, as China and ASEAN reasoned before signing the FTA. A country may seek trade agreements with targeted partners for the latter's resources, including energy resources and raw materials (for example, China with ASEAN, Australia, New Zealand, the South African Customs Union, the Gulf Cooperation Council and the Central Asian countries in the Shanghai Cooperation Organization), technology and capital (China with Australia, New Zealand and Iceland), or access to a bigger market of which the partner country has access to (China with Chile for access into the Americas, and with SACU to Africa) if rules of origin are not restrictive between the partner country and the bigger market in concern.

When a country's national interests in international economic strategy and in domestic development have different policy implications, it is difficult for policymakers to judge to which they should give priority. Peter Katzenstein believes that "the main purpose of all strategies of

Politics of China-ASEAN Economic Relations: Assessing the Move toward a Free Trade Area," Asian Perspective 26, no. 4 (2002): 53-82.

${ }^{29}$ Jeffry Frieden, "Sectoral Conflict and U.S. Foreign Economic Policy, 1914-1940," International Organization 42 (Winter 1988): 59-90. 
foreign economic policy is to make domestic policies compatible with the international political economy." ${ }^{30}$ Putnam also recognizes the rational maxim of "to get along, go along", which is likely to be more common the more dependent is a nation on the international environment. ${ }^{31}$ Still, a recurring dilemma for policymakers in developing countries is whether to open the national economy and endure short-term pains for long-term gains like enhanced competitiveness, or to protect domestic strategic and infant industries for economic security and a chance to gain international competitiveness. These alternative approaches are reflected in the debate between the 'Washington consensus' and the 'developmental state' over economic liberalization. The question is which approach agencies of the state think is more important, growth or development, economic interdependence or sovereignty.

With a similar logic, regionalism can have contradictory functions for regional countries in relation to their obligations in the global trade regime. Regional liberalization can be a mechanism the state uses to push forward domestic reforms so as to gradually fulfil liberalization in the global system. In a way, regional trade agreements can help the state to overcome status quo bias when domestic groups are uncertain about the size of the adjustment costs associated with liberalizing trade multilaterally. ${ }^{32}$ Trading blocs may retain barriers against outside competition and external protection ensures that firms in the region fully internalize the scale effects of larger markets, creating opportunities to leapfrog foreign competitors through "import protection as export promotion. ${ }^{33}$ On the flip side, regionalism can also be a tactic that a state uses to permanently defy WTO obligations by maintaining discriminatory and protectionist policies. Trade is an area where governments face resistance from domestic sectors that bear significant costs, because such international economic exchanges are susceptible to swift changes due to price or supply shocks, technological change and/or foreign government policy changes. Fixed exchange rate systems may be vulnerable to unanticipated domestic pressures to devalue. Therefore, what often happens is that leaders enter into international trade

\footnotetext{
${ }^{30}$ Peter J. Katzenstein, "International Relations and Domestic Structures: Foreign Economic Policies of Advanced Industrial States," International Organization 30, no. 1 (Winter 1976): 1-45.

${ }^{31}$ Putnam, "The Logic of Two-Level Games."

${ }^{32}$ Shang-Jin Wei and Jeffrey A. Frankel, "Can Regional Blocs Be a Stepping-Stone to Global Free Trade? A Political Economy Analysis," International Review of Economics and Finance 5, no. 4 (1996): 339-47. ${ }^{33}$ Paul R. Krugman, "Import Protection as Export Promotion: International Competition in the Presence of Oligopoly and Economies of Scale," in Imperfect Competition and International Trade, ed. Gene M. Grossman (Cambridge, Mass.: MIT Press, 1993), 75-86.
} 
agreements to resist domestic pressure to erect more protection than is ideal, but they also need some flexibility to temporarily and selectively give protection in the future if sizable domestic pressures arise. ${ }^{34}$

In summary, regional economic cooperation gives a good example of the inseparable nature of state economic and political interests, and the interconnection between national interests at the domestic, regional and global levels. The task in analyzing the interests involved in policymaking on regional economic cooperation includes investigating at the domestic level whether policy coalitions were formed along industry or class lines, what the preferences of local governments were, how the career goals of government officials affect their ability to speak for the sectors they are in charge of, and how much impact intra-industry trade had on the formulation interests of domestic actors. It also includes investigating at the state level what political and economic objectives the state expected to achieve through regional economic cooperation, as well as whether the government perceived regional economic cooperation as a means for propelling domestic reform. Those interests are sometimes coherent but often they are in conflict. How do policymakers decide the priority for the state? Furthermore, when state interests and domestic societal interests are in conflict, which one will eventually direct national policy and by definition become 'the national interest'? Mansfield and Busch have suggested that it would be fruitful to integrate societal models - especially models of endogenous protection-and statist models. ${ }^{35}$

It is difficult to define the national interest, which has complex constituencies with varying priorities and changes over time. Rationalist explanations usually give post hoc definitions of the national interest and fail to explain why a specific equilibrium was pursued instead of other possible equilibria. Whether regarding states as a unitary actor, or as institutions created by rational actors, ${ }^{36}$ rational choice models assume that the interests of the state and the actors are exogenous and given, without fully considering the dynamic formation and transformation of the national interest. This leads partly to the ideational argument that ideas

\footnotetext{
${ }^{34}$ Milner, Rosendorff, and Mansfield, "International Trade and Domestic Politics."

${ }^{35}$ Edward D. Mansfield and Marc L. Busch, "The Political Economy of Nontariff Barriers: A CrossNational Analysis," International Organization 49, no. 4 (Autumn 1995): 723-49.

${ }^{36}$ As reflected in the arguments of new institutional economics and rational institutionalism.
} 
shape interests, and partly to the institutional enquiry about what determines the influence of domestic interests on the state's definition of the national interest. As mentioned before, existing studies of China's regional economic cooperation have been conducted at the international level, assuming that the Chinese state is authoritarian and approximates a unitary rational actor.

However, it is worth investigating how accurate that assumption is. In other words, how much constraint and influence can various domestic actors have on policymaking and why? And, how much 'irrationality' weighs in Chinese foreign economic policymaking? As will be discussed in the case studies, although state interests are crucial motivations of China's regional economic cooperation, its policymaking is constrained by various conflicting domestic interests and influenced by different ideas about where China's national interest lies. The next section will review existing literature regarding the role of ideas in foreign economic policymaking, and consider which ideas may have an impact on and how they influence China's policymaking on regional economic cooperation.

\subsection{Ideas in foreign economic policymaking}

The counterpart to interests is ideas, including world-views, identity, principled and causal beliefs, and norms. Human behaviours are directed by a combination of cost-and-benefit rational calculation and ideas on what is appropriate. As will be discussed later, it is difficult to draw a fine line between objectivity and subjectivity, or interests and ideas, but it is helpful to know why ideas matter, what types of ideas may be involved in the policymaking on regional economic cooperation, and how they may influence policy decisions.

\subsubsection{Why ideas matter in foreign economic policymaking}

Individuals' calculation of interests on one issue can originate from their desire to obtain certain material benefits; it can also be socially constructed, that is, formed and transformed by the social environment, which is deeply imprinted by time and place. According to Frank 
Trentmann on the relationship between culture and free trade, "rationality stands for what social actors find plausible and meaningful at a historical moment." ${ }^{37}$

In foreign economic policymaking, ideas play a crucial role because policymakers follow their perceptions of what constitutes national interests and which means are best to achieve them. Particularly in this policy area, where a complex mixture of political-economic, domesticinternational and individual-collective interests are intertwined, ideas held by national policymakers are particularly decisive for them to choose among policy alternatives.

Ideas are powerful in China. Ideology, beliefs and discourse have played a prominent role in thousands of years' Chinese history. 'Dao' - the moral cause of governing the nation - is consistently upheld as the ultimate goal of statesmen, as well as a favourite quote by the Chinese Premier Wen Jiabao. ${ }^{38}$ In a culture that places supremacy of the collective over individuals, and easily equates the pursuit of material benefits with individualism or selfishness, the dominant definition of national interests has paramount force, at least in rhetoric. The respect for private property by the state and by the society has grown in the process of marketization, ${ }^{39}$ but it remains a question of to what extent domestic interests can stand up to the state when the state pursues policies based on reasons of pertinence to national interests. The power of ideas in Chinese policymaking comes partly from culture and history, and partly from the autonomy - sometimes deity - that the nation has granted to its leaders. In Mao's PRC, ideology was the central guidance to national policies. In the post-Mao era, individual interests and pragmatism are more recognized by the state and the society, but the leaders are still largely believed to represent the overall national interest and there is competition of domestic interests to assert they represent national interest. Moreover, many areas in foreign economic policy are new to the Chinese; the policymakers cannot follow practices of the collapsed former Soviet Union, but they are not supposed to directly copy Western templates either because China is constructing a 'socialist market economy'. Regional economic cooperation is one of the newest

\footnotetext{
${ }^{37}$ Frank Trentmann, "Political Culture and Political Economy: Interest, Ideology and Free Trade," Review of International Political Economy 5, no. 2 (Summer 1998): 217-51.

${ }^{38}$ Mencius, "Mengzi. Gongsun Chou Xia". "De dao duo zhu, shi dao gua zhu" [those who have the right cause win support, those who lose the right cause have little support] is a phrase from Mencius that the Chinese Premier Wen Jiabao has quoted on various occasions on domestic and international affairs, such as his inaugural speech as Premier, comments on Taiwan, Japan, and the US.

${ }^{39}$ The protection of private property was written for the first time into the Chinese Constitution in 2004.
} 
areas to the Chinese policymakers and domestic groups. Within the constraints of their worldviews and information, the Chinese are in the process of probing and defining what their interests are and how to pursue them in regional economic cooperation.

\subsubsection{Ideas related to regional economic cooperation and Chinese views}

Which ideas may be brought into the policymaking on regional economic cooperation? Several types can be summarized from existing literature: the world view, the understanding of national identity, causal beliefs about regionalism and the view on the relationship between regionalism and globalization. This certainly does not claim to be an exhaustive list but only one of important candidates.

\section{World View}

The world view on international relations is the fundamental ideational framework policymakers have for the conduct of international relations. Whether policymakers hold a realist (mercantilist) or a liberal world view determines the direction of many specific state foreign economic policies. Different ideologies are reflected in different policies of regionalism: a realist state seeks trade surplus, with predatory and exploitive behaviours, while a liberal state promotes a win-win situation even if it is not the best outcome for itself. From an opposite view, for a realist country in pursuit of international leadership, liberal trade policy may be a component of its long-term global agenda with some necessary short-term 'self-sacrifice', and this belief can be powerful in confronting domestic protectionist pressures. ${ }^{40}$ In relation to countries outside the region, realist regionalism is exclusive and discriminatory against nonmembers, while liberal regionalism is inclusive and non-discriminatory. Judged by this standard, the new wave of regionalism at the end of the twentieth century is observed by some as a sign of the revival of realism in state ideology. ${ }^{41}$

\footnotetext{
${ }^{40}$ Destler, American Trade Politics. Lake, "International Economic Structures and American Foreign Economic Policy, 1887-1934."

${ }^{41}$ Jagdish N. Bhagwati, "Regionalism and Multilateralism: An Overview," in New Dimensions in Regional Integration, ed. Jaime de Melo and Arvind Panagariya (New York: Cambridge University Press, 1993), 22-51
} 
The Chinese leadership has changed tremendously from an overall antagonist ideology that perceived war with the West to be inevitable, to a more cooperative one that believes peace and development are possible. This coincides with the foreign economic policy change from isolation to liberalization. On regional economic cooperation, however, it is uncertain what ideology the Chinese leadership upholds in relation to its partners and to non-partners.

Questions remain whether China's regional cooperation is inclusive or exclusive, and whether it is compatible with global multilateral cooperation, which will be analysed in the case studies in following chapters. China has tried to exclude Taiwan from international organizations but that was obviously out of sovereignty concerns in the first place. ${ }^{42}$ On the participation list of the East Asia Summit, China did not support the inclusion of Australia or India, but it is negotiating or studying a free trade agreement with the two. On this point, Katzenstein may be right that it is risky to label a state mercantilist or liberal because at any one time policymakers may subscribe to a mixture of these views and incentives. ${ }^{43}$

\section{National identity}

The understanding of national identity in the region and in the world is important in foreign economic policymaking because identity is the starting point of perceptions on how one should behave. National identity is heavily influenced by cultural and historical legacies, but is subject to change over time and in different environments. It is also informed with a consciousness of how other states perceive it. Moreover, a state can have multiple identities at a single historical moment if put under various contexts - for example, a global "spoiler" can be a regional leader at the same time. Self-description as a 'victim' China or a 'great power' China implies whole sets of different foreign policies. ${ }^{44}$ Evan Medeiros and M. Taylor Fravel have noted such ideational change in the Chinese foreign policy from seeing the country as the victimized developing nation in the Mao Zedong and Deng Xiaoping eras to viewing it as an

\footnotetext{
${ }^{42}$ Examples include the APEC, the WTO, and the World Health Organization.

${ }^{43}$ Katzenstein, "International Relations and Domestic Structures."

${ }^{44}$ Neil Renwick and Qing Cao, "China's Political Discourse Towards the 21st Century: Victimhood, Identity, and Political Power," East Asia: An International Quarterly 17, no. 4 (Winter 1999): 111-43.
} 
emerging great power with varied interests and international responsibilities. ${ }^{45}$ Peter Van Ness points out that the conflict of the third-world identity in foreign policy with economic development in the 1980 s led to the reshaping of China's 'official national identity' ${ }^{46}$ Robert Scalapino underlines the regional identity of China in East Asia, perceived by Chinese policymakers, as the Central Kingdom, worthy of being influential and respected. ${ }^{47}$ From a similar angel, Beijing's recent proactive stance in East Asia has been understood by some as a sign of reviving nationalism or a strategy to resume the tribute system of the Ming and Qing dynasties. ${ }^{48}$ Whether such a view is relevant to China's regional economic cooperation will be discussed in the case studies.

Equally important to how China conceives itself, is the view on what international role China should play — a defiant revisionist or a 'responsible' global player; a third world representative or a regional leader; a free rider or a rising hegemon. Harold Jacobson and Michel Oksenberg have observed that China's activities in the IMF and World Bank before 1990 were not disruptive but largely compliant. ${ }^{49}$ Studies on China's compliance with the WTO rules have found that China has fulfilled many of its commitments to the WTO since accession, but the level of compliance to some provisions is not satisfactory, in particular on behind-theborder issues. ${ }^{50}$ China's perceived international role in the 21 st century is worth studying because the power of China and the structure of international relations have changed tremendously compared with the early 1990s. To what extent identity matters in Chinese foreign

\footnotetext{
${ }^{45}$ Evan S. Medeiros and M. Taylor Fravel, "China's New Diplomacy," Foreign Affairs 82, no. 6 (Nov/Dec 2003): 22-35

${ }^{46}$ Peter Van Ness, "China as a Third World State: Foreign Policy and Official National Identity," in Working Paper (Canberra: Department of International Relations, Research School of Pacific and Asian Studies, Australian National University, 1991).

${ }^{47}$ Robert A. Scalapino, "China's Multiple Identities in East Asia: China as a Regional Force," in China's Quest for National Identity, ed. Lowell Dittmer and Samuel S. Kim (Ithaca and London: Cornell University, 1993), 215-36.

${ }^{48}$ Michael Leifer, "The ASEAN Peace Process: A Category Mistake," The Pacific Review 12, no. 1 1999): 25-38. Christopher R. Hughes, "Nationalism and Multilateralism in Chinese Foreign Policy: Implications for Southeast Asia," The Pacific Review 18, no. 1 (March 2005): 119-35. Eric Chu Cheow Teo, "Paying Tribute to Beijing: An Ancient Model for China's New Power," International Herald Tribune Wednesday, January 21, 2004.

49 Jacobson and Oksenberg, China's Participation in the IMF, the World Bank, and GATT.

${ }^{50}$ Gerald Chan, "China and the WTO: Theory and Practice of Compliance," International Relations of the Asia-Pacific 4 (2004): 47-72; Terence P. Stewart, "China's Compliance with World Trade Organization Obligations: A Review of China's 1st Two Years of Membership," (U.S.-China Security and Economic Review Commission, 2004. Huang, Yasheng, Is China Playing by the Rules? Free Trade, Fair Trade and WTO Compliance, Statement at the Congressional-Executive Commission on China, September 24, 2003. Pearson, Margaret M., Is China Playing by the Rules? Free Trade, Fair Trade and WTO Compliance, Statement at the Congressional-Executive Commission on China, September 24, 2003.
} 
economic policymaking, particularly in regional cooperation, is a question yet to be answered by empirical research.

\section{Approaches to realize regional economic cooperation}

Causal beliefs are equally important to policymaking because they serve as 'roadmaps' on what approach the state should adopt to realize objectives in regional economic cooperation, especially when the state faces a complicated issue. ${ }^{51}$ In regional economic cooperation, some states (for example, China, ASEAN, Mexico, Chile) prefer a gradual, flexible and conservative approach and others (for instance, Australia and the US) prefer a single-undertaking, legalist and comprehensive approach. To be specific, some would like free trade agreements to have a long phase-in period (ten to fifteen years for the China-ASEAN FTA), an extensive list of sensitive products to be exempted from tariff reduction (China's FTAs with Chile and with ASEAN) or alternatively a positive list identifying specific products to liberalize (China's FTAs with Pakistan and Thailand), contents covering only traditional border issues (mostly between developing countries), consultation as the means of dispute settlement, and some clause to allow withdrawal from the agreement if severe damage to domestic economy happens. On the contrary, other countries require free trade agreements to be a whole-basket endeavour, comprehensive in contents (with a restrictive negative list), covering wide behind-the-border issues, and having legal arbitration as the means of dispute settlement. One reason is that with globalization, multinational corporations prefer national standards to be harmonized, traderelated investment barriers eliminated, restrictions on equity ownership relaxed, dispute settlement procedures established, and protection of intellectual property enhanced. Multilateral negotiations at the WTO on these sorts of behind-the-border trade barriers have not achieved substantial progress to date. ${ }^{52}$ The different national approaches to regionalism can be attributed to different cultures between Asia and the West, and to the different levels of economic development. If those two approaches represent two extremes, China has obviously been inclined to the former one.

\footnotetext{
${ }^{51}$ Judith Goldstein, Robert O. Keohane, and Social Science Research Council (U.S.) Committee on Foreign Policy Studies, Ideas and Foreign Policy: Beliefs, Institutions, and Political Change, Cornell Studies in Political Economy (Ithaca: Cornell University Press, 1993).

${ }^{52}$ Chase, "Economic Interests and Regional Trading Arrangements: The Case of NAFTA."
} 


\section{The relationship between regionalism and multilateralism}

The view on the relationship between regionalism and global economic cooperation (commonly referred to as multilateralism) is particularly important in determining whether and in what form a country adopts regionalism. Explaining Zhu Rongji's proposal for the CAFTA and subsequently the Chinese finance minister's indication of cooperation with other East Asian countries in economic integration, Nicholas Lardy has pointed out an important reason - the leadership has recognized the economic advantages of globalisation. ${ }^{53}$ But he did not specify why a preference for globalisation would lead to policies of regional economic cooperation because participation in regionalism can be a step to prepare China for further integration into the world, or a defiant measure to delay the pace of globalisation. The latter consideration is possible because China's participation in globalization has had profound impacts on domestic industries and regions. Its entry into the WTO has posed immense challenges to domestic sectors like agriculture, chemical and pharmaceutical industries, heavy industries, the auto industry, information industries, telecommunication services and finance. Inland provinces are more vulnerable than coastal ones to international competition because those industries historically have tended to concentrate in those areas. ${ }^{54}$ These industrial and local actors were most vocal in questioning the policy of WTO accession. The adverse economic effects may cause social instability, threatening the legitimacy of the regime. A crucial task for the Chinese government is to embrace globalization and at the same time address the side effects of globalisation. In this regard, regional economic cooperation can be a fine way of liberalizing parts of the economy, while protecting other parts from global challenges. ${ }^{55}$ Therefore, it is worth investigating through case studies the state's position on whether free trade agreements should be strictly WTO-compatible or having so many exclusions that it is actually 'WTOdefiant'.

\footnotetext{
${ }^{53}$ Nicholas R. Lardy, Integrating China into the Global Economy (Washington, D.C.: Brookings Institution Press, 2002): 164.

${ }^{54}$ Wang, "The Social and Political Implications of China's WTO Membership." Also see Shuming Bao, Shuanglin Lin, and Changwen Zhao, eds., The Chinese Economy after WTO Accession (Aldershot, Hants, England; Burlington, VT: Ashgate, 2006); Fung, Pei, and Zhang., eds., China and the Challenge of Economic Globalization: The Impact of WTO Membership.

55 John Ravenhill, "The New Bilateralism in the Asia Pacific," Third World Quarterly 24, no. 2 (2003): 299-317.
} 


\subsubsection{How ideas influence policy decisions and their role in the Chinese context}

The above discussion on why and which ideas matter have inherent implications on how they play a role in foreign economic policymaking. The existing literature has also pointed out some specific ways in which ideas influence policy decisions.

\section{Through discourse}

Ideas can influence foreign economic policymaking through discourse. It creates a discursive environment benevolent to some policies and dismissive for others, provides ideological bonds for public mobilization, and sets the parameters of the public debate. Liberal discourse can shift the discursive focus from curbing imports to opening up international markets, and legitimate free trade as the only rational option. ${ }^{56}$ Many great discursive debates have shaped China's history for thousands of years. To name a few: between isolation of the nation and 'xi xue dong yong', 'yi yi zhi yi' [utilize Western knowledge for the East; use foreign resources to control foreign countries] before the Opium War in the Qing Dynasty; between self-reliance and opening in the late 1970s; and between command economy and market economy in the early 1990s. As a result of the last debate, although economic liberalization has caused economic and social problems, Deng Xiaoping's cause of 'reform and opening up' has not been challenged, and those problems have been blamed on specific approaches or corruption. However, as Michael Yahuda says, because of the continual process of reform, there is continual tension at the heart of Chinese politics that has mitigated the development of deep or consistent international cooperation. ${ }^{57}$ It is worth investigating through case studies how this discursive tension has affected China's regional economic cooperation, and importantly in each case which side prevails over the other and why.

The state tries both to shape and to adapt to discursive environments at the domestic and international levels. Regaining the WTO membership was powerfully associated with national pride in the official and public discourse in China despite its negative implications on parts of the Chinese economy. In its engagement with the organization, Beijing wants its domestic

\footnotetext{
${ }^{56}$ Trentmann, "Political Culture and Political Economy." Destler, American Trade Politics. ${ }^{57}$ Michael Yahuda, "How Much Has China Learned About Interdependence?" in China Rising: Nationalism and Interdependence, ed. David S.G. Goodman and Gerald Segal (London and New York: Routledge, 1997), 7-26.
} 
audience to view the state as a tough negotiator and defender of Chinese interests abroad. ${ }^{58}$ At the regional level, the discourse on the need to strengthen East Asian cooperation in the late 1990s added momentum to the participation by regional countries, although they were not certain of the economic implications of deeper integration. To 'be in the driver's seat', China could be forced by the regional discourse to change from a passive stance on multilateral regional frameworks toward a more proactive and devoted manner. The Chinese government has also spared no effort in extinguishing the discourse of the China threat and even China's 'rise' which may exacerbate the threat image in the region. ${ }^{59}$

Moreover, Milner et al. argue that international agreements also convey information to the public about the behaviour of their leaders, allowing them to better judge their leaders particularly in favour of liberal rather than extractive economic policies. ${ }^{60}$ The information can also be that the leaders are seeking international opportunities for the nation and trying to be tough in international negotiations. To this end, regional cooperation may be more eye-catching for national leaders than the WTO for the smaller number of participants. ${ }^{61}$

\section{Through learning}

As a source of policy change, ideas have influence on policymaking also through the learning of policymakers. The demand for policy change needs to be met by the supply of ideas on how to restructure politics to accommodate the changing economic and political needs of central policymakers. ${ }^{62}$ New ideas may come from intellectuals, domestic interest groups, foreign actors, international organizations or the policymakers' own experiences. Knowledge and international norms such as multilateralism and liberalism are often instilled by international organizations into national governments through dialogue and the latter's

\footnotetext{
${ }^{58}$ Mertha and Pahre, "Patently Misleading."

59 'Peaceful rise' [heping jueqi] was first proposed by Zheng Bijian, then Vice President of the Central Party School, and was used by Wen Jiabao at a speech at Harvard University on 10 December 2003. However, the element of 'rise' caused concern from other countries because of its element of relative power transition. As a result, the Chinese government changed the rhetoric to 'peaceful development' and 'a harmonious world'.

${ }^{60}$ Milner, Rosendorff, and Mansfield, "International Trade and Domestic Politics."

${ }^{61}$ See Alan Beaftie and Andrew Bounds, "Sceptics Fear Political Ties that Bind Free Trade", Financial Express (Bangladesh), 9 Oct. 2006, as quoting Pascal Lamy's comments on regionalism's better effect of getting politicians in the news than the WTO's.

62 Judith Goldstein, "The Impact of Ideas on Trade Policy: The Origins of U.S. Agricultural and Manufacturing Policies," International Organization 43, no. 1 (Winter 1989): 31-71.
} 
participation. For example, the rush to free trade by developing countries was partly due to a learning process and the discrediting of the idea that rapid development can be achieved through import-substituting policies. ${ }^{63}$ China's integration into the world economy is a process of experimenting and learning. Some studies have depicted the profound impact of China's dialogue with and participation in international organizations on its perceptions toward international cooperation and international norms. ${ }^{64}$ In their detailed account of China's initial participation in the IMF, World Bank and GATT, Jacobson and Oksenberg documented how the interchange of personnel and socialization process brought ideas into the national government and affected the government's assessment of costs and benefits associated with participating in international economic arrangements. To be sure, there was a convergence between the views of China's leaders and the international organizations concerning the measures necessary to sustain and accelerate growth.

Likewise, China's experiences in the second-track Pacific Economic Cooperation Council (PECC) and the Pacific Trade and Development Forum (PAFTAD) are noted to be necessary preparations for China's application to join the first-track APEC. ${ }^{65}$ Cheng-Chwee Kuik suggests that the role of multilateralism in China's policy towards ASEAN increased because China's experiences in the ASEAN Regional Forum (ARF) — which operated in the "ASEAN Way" made it realize that multilateral forums would not necessarily be harmful to national security, as it used to think before the $1980 \mathrm{~s} .{ }^{66}$ Its multi-track involvement in regional initiatives, such as PECC, PAFTAD and APEC, may have prepared China better for regional cooperation in both width and depth.

John Ravenhill points out that regionalism has proliferated because of effects of 'demonstration', 'emulation' and 'contagion', ${ }^{67}$ of which learning is a component. The content of regional economic cooperation has become so complex today that in many cases its

\footnotetext{
${ }^{63}$ Michael J. Hiscox, "The Domestic Sources of Foreign Economic Policies," in Global Political Economy, ed. John Ravenhill (Oxford: Oxford University Press, 2005).

${ }^{64}$ Jacobson and Oksenberg, China's Participation in the IMF, the World Bank, and GATT.

${ }^{65}$ See for example, Lawrence T. Woods, "Diplomacy and International Nongovernmental Organizations: A Study of the Pacific Economic Cooperation Movement," (PhD thesis, Australian National University, 1998).

${ }^{66}$ Cheng-Chwee Kuik, "Multilateralism in China's ASEAN Policy: Its Evolution, Characteristics, and Aspiration," Contemporary Southeast Asia 27, no. 1 (2005): 102-22.

${ }^{67}$ Ravenhill, "Regionalism."
} 
policymaking is a process of mutual learning and concerted agenda-setting between partner countries. If carried out thoroughly, regionalism is not traditional barter trade of concessions anymore but a 'systematising of knowledge and principles'. ${ }^{68}$ It is valuable to see through case studies to what extent learning has contributed to China's participation in regional economic cooperation, and to what extent regionalism has had such a 'synthesising' effect on China.

Different from the WTO and IMF cases, in which multilateralism and liberalization are generally desired by the organisation, the messages sent to China from foreign governments and international organizations on regional economic cooperation have not been so unified. The role played by actors in composing regionalism into national policies therefore must have been more than introducing international norms to the central leadership, especially considering possible opposition by some other domestic interests. As discussed later, more answers need to be found from institutional arrangements the actors make.

\section{Through key actors}

From the top of the policymaking structure, ideas held by central policymakers, especially the political leadership, are especially decisive on policy outcomes. As discussed previously, beliefs held by central policymakers about the national interest in economic liberalization can be powerful in confronting domestic protectionist pressures. ${ }^{69}$ In bilateral trade negotiations, some deadlocks in trade negotiations have been overcome only when leaders intervened. ${ }^{70}$ No doubt this is relevant in the Chinese context - the leadership's perception of what constitutes national interest and how it should be achieved is especially crucial.

Apart from the leadership, if idea-infused, or 'missionary', institutions survive and thrive in domestic bureaucratic politics, their close interaction with other bureaucracies can lead to an

\footnotetext{
${ }^{68}$ Ann Kent, "China's International Socialization," Global Governance 8, no. 3 (Jul-Sep 2002): 343-64. Ann Kent, "China, International Organizations and Regimes: The ILO as a Case Study in Organizational Learning," Pacific Affairs 70, no. 4 (Winter 1997/1998): 517-32. Yasheng Huang, "Is China Playing by the Rules? Free Trade, Fair Trade and WTO Compliance," the Congressional-Executive Commission on China, 2003.

${ }^{69}$ I. M. Destler, American Trade Politics, 3rd ed. (Institute for International Economics, 1995). Lake, "International Economic Structures and American Foreign Economic Policy, 1887-1934."

${ }^{70}$ For instance the Australia-US FTA. See Tor Krever, "The US-Australia Free Trade Agreement: The Interface between Partisan Politics and National Objectives," Australian Journal of Political Science 41, 1 (March 2005): 51-69.
} 
increase in shared ideas and convert other bureaucratic units to their idea. ${ }^{71}$ The Chinese MOFCOM is noted for its overall liberal policy standing and has played such a role in China's foreign economic policymaking, for instance during China's WTO accession process. ${ }^{72}$ The crucial question here is how much influence the missionary institutions have on others and how much power they have in the policymaking process.

Chinese policymakers' ideas are widely acknowledged to be influenced by scholars, private businesses and foreign delegations to varying degrees. Scholars and think tanks in China have grown in number and scope of their participation in government policy decision since the early 1980 s, particularly in foreign economic policy area where expertise is required. ${ }^{73}$ Premier Zhu Rongji was known to rely upon a group of advisers for policy advice, among whom many were liberal economists. ${ }^{74}$ One factor in policy change from that of the first generation of leadership may be the shift in location of overseas training of many Chinese officials from the Soviet Union to the West. ${ }^{75}$ Besides, overseas Chinese increasingly play a significant role in influencing various levels of government with new ideas and knowledge. Foreign businessmen and multilateral corporations play a similar role while pursuing profits. ${ }^{76}$ New ideas are also introduced by foreign scholars and delegations. The interlocutors for foreign governments sometimes know the situation in China better than the Chinese officials in Beijing. To be sure, there is a question of whether the Chinese government has utilized or 'co-opted' scholars as their spokesmen. However, if the leadership does not have a clear inclination on one policy, and when coordination with other countries is needed in policy formulation, the room of government manipulation of scholars can be limited.

\footnotetext{
${ }^{71}$ Daniel Drezner, "Ideas, Bureaucratic Politics, and the Crafting of Foreign Policy," American Journal of Political Science 44 (October 2000): 733-49.

72 See for example, Sheng, The Political Economy of China's Foreign Trade Policies. Pearson, "The Case of China's Accession to GATT/WTO."

${ }^{73}$ David M. Lampton, ed., The Making of Chinese Foreign and Security Policy in the Era of Reform, 1978-2000 (Stanford: Stanford University Press, 2001). Stuart Harris, "Globalisation and China's Diplomacy: Structure and Process," in Working Paper (Canberra: Department of International Relations, Research School of Pacific and Asian Studies, Australian National University, 2002). David Shambaugh, "China's International Relations Think Tanks: Evolving Structure and Process," The China Quarterly 2002, no. 171 (2002): 575-96. Merle Goldman, "The Emergence of Politically Independent Intellectuals," in The Paradox of China's Post-Mao Reforms ed. Merle Goldman and Roderick MacFarquhar, Harvard Contemporary China Series (Cambridge, Mass.: Harvard University Press, 1999), 283-307.

${ }^{74}$ South China Morning Post, May 13, 1998.

${ }^{75}$ Harris, "Globalisation and China's Diplomacy." David Shambaugh, "China's International Relations Think Tanks". Lampton, ed., The Making of Chinese Foreign and Security Policy.

${ }^{76}$ Harris, "Globalisation and China's Diplomacy."
} 
In summary, ideas can play a crucial role in foreign economic policymaking. To study this role, firstly, it is important to discern what specific ideas are held by central policymakers about what constitutes the national interest as the foreign economic policy objective. Several types of ideas are of particular importance to their definition of national interests, including mercantilist or liberal world views, an exclusive or inclusive position on regionalism, the national identity of China (a responsible great power, a revisionist or status quo power, or a hegemonic Central Kingdom), the causal beliefs on how to achieve regional economic cooperation, and the perception on the relationship between regionalism and global economic liberalization. Secondly, one needs to study how ideas influence policy decisions through domestic and international discourses, learning processes and the influence of key actors such as the political leaders, central agencies and scholars.

\subsubsection{Limitation of the ideas literature and the relationship between interests and ideas}

Katzenstein believes the degree of ideological conflict in the state is a critical determinant of the consistency and content of foreign economic policy. ${ }^{77}$ However, the ideas literature has limited power for explaining how policy is crafted when competing ideas coexist or when ideas and interests compete. ${ }^{78}$ Different groups assign different meanings to the national interest. The military may uphold state security as the highest national interest; for the foreign trade ministry, the expansion of trade; and the Central Bank, financial stability. There may be internationalists within the government who advocate compliance to international norms and cooperation, and conservatives who stress the traditional values of the nation. Apart from the "cosmopolitannativist' spectrum, many studies have noted a critical divide within the Chinese elite between those who enthusiastically support economic reforms and liberalization, and those who are sceptical or opponents. ${ }^{79}$ Sometimes, ideational claims of the national interest are camouflage used by actors in pursuit of self-interests. Whether sincerely held or not, different ideas compete in defining the national interest for foreign economic policy.

\footnotetext{
${ }^{77}$ Katzenstein, "International Relations and Domestic Structures."

${ }_{78}^{78}$ Drezner, "Ideas, Bureaucratic Politics, and the Crafting of Foreign Policy."

79 Jacobson and Oksenberg, China's Participation in the IMF, the World Bank, and GATT. Shirk, How China Opened Its Door.
} 
Apart from competing ideas in foreign economic policymaking, self-interests often articulate themselves without any ideational veil and compete with ideas of national interest in influencing the final policy outcome. Jacobson and Oksenberg attribute the success of international economic organizations' initial engagement with China to a process of dialogue instead of imposition, to mutual respect and the self-confidence of the Chinese officials. ${ }^{80}$ But they do not explain why the ideas of some officials could win over domestic opponents and be adopted by the central decision makers. Moreover, when Beijing changed its view on multilateral institutions as being anti-communist arrangements to them being useful platforms that China can utilize to advance its own objectives, it is hard to determine whether this was the effect of ideas or interests, or both.

The relationship between ideas and interests in foreign economic policymaking is highly interactive and constitutive. On the one hand, interests are shaped by ideas; actors within the same social environment are likely to share views and interests. As a result, ideas and interests join forces to push state behaviour in one direction. In this case, it is artificial to disentangle the effect of ideas from the effect of material interests. As Trentman says, "interest has had evolving meanings and functions... There was no inherent discursive conflict between ideas and interests." ${ }^{\prime 81}$ On the other hand, actors' experiences of redistribution of interests lead to introspection and the revision of previously-held ideas. Ramification of ideas is likely to happen because of different experiences or different ways of reflection.

After looking at the role of interests and ideas in foreign economic policymaking, the question still remains as to who can succeed in incorporating their ideas or interests into actual national policies. The convergence and divergence between interests and ideas need to be explored more directly and precisely. In a symposium on different approaches to foreign economic policymaking, John Ikenberry concludes that the role of institutions should be highlighted. ${ }^{82}$ After reviewing the study of domestic politics of trade policies, Milner suggests

\footnotetext{
${ }^{80}$ Jacobson and Oksenberg, ibid.

${ }^{81}$ Trentmann, "Political Culture and Political Economy."

${ }^{82}$ G. John Ikenberry, "Conclusion: An Institutional Approach to American Foreign Economic Policy," International Organization 42, no. 1 (Winter 1988): 219-43.
} 
that a synthesis of preferences and institutions is needed to have a comprehensive explanation of policymaking. ${ }^{83}$

Accordingly, two questions need to be asked about Chinese foreign economic policymaking. First, what ideas and what interests enter policymaking? Second, how do ideas and interests interact with each other so that some are incorporated into the national policy and some are not? In addressing the second question, institutional theories have provided valuable directions.

\subsection{Institutions of foreign economic policymaking and the Chinese settings}

Institutions are canals that channel and structure the interactions among flows of interests and ideas in policymaking. While many theories achieve parsimony by pointing to particular variables that are alleged to be decisive, institutional analyses focus on illuminating the linkages among different variables. To perform and to make regular judgments, institutions adopt rules, norms, or routines. ${ }^{84}$ They channel and structure the interplay among policy preferences by aggregating preferences, distributing power, setting agendas and embedding certain ideas and interests. ${ }^{85}$ The content of each idea or interest is important, but institutions can grant a better chance to the expression of some and discriminate against others. Which idea or interest prevails hinges on the characteristics of the policymaking institution. Rodrik pointed out that theoretical and empirical work relating [domestic] institutional context to trade policy outcomes is in its infancy but should be a promising area of research. ${ }^{86}$

Traditional institutional theories divide institutions into formal and informal categories based on their organizational forms. For instance, the 'government politics model' of Allison emphasizes the formal procedural and structural rules of government institutions. Studies on trade policymaking have examined the linkage between trade liberalization and the regime type (whether a democracy or an autocracy), the structure of the political system (presidential,

\footnotetext{
${ }^{83}$ Helen V. Milner, "The Political Economy of International Trade," Annual Review of Political Science 2 (1999): 91-114.

${ }^{84}$ Allison and Zelikow, Essence of Decision, 152.

${ }^{85}$ James G. March and Johan P. Olsen, Rediscovering Institutions (New York: Free Press, 1989). Peter Hall, Governing the Economy: The Politics of State Intervention in Britain and France (New York: Oxford University Press, 1986).

${ }^{86}$ Dani Rodrik, "The Political Economy of Trade Policy", in Handbook of International Economics, ed. Gene M. Grossman and Kenneth Rogoff (Amsterdam: Elsevier Science BV., 1995), Vol. III: 1457-94.
} 
parliamentary, multi-cameral and multi-party systems), and the election rules. ${ }^{87}$ Doak Barnett's study of the PRC's foreign policymaking was one of the earliest attempts to look at China's policymaking through its formal bureaucratic establishment. ${ }^{88}$ A later book by Lu on China's foreign policy making follows suit, organized around the formal role of each major political actors in China, but has little to say about foreign economic policymaking. ${ }^{89}$

New institutionalisms in social sciences give an insightful perspective to policymaking studies - more important than the formal characteristics of state or societal institutions per se is how the underlying institutional configuration derives policy priorities ${ }^{90}$ Here I will review literature on the institutions in foreign economic policymaking according to their inherent institutional features. This is because there is a convergence of views in this literature that specific institutional forms (such as the regime type or the election system) may not be the fundamental reason for variation in the impacts of institutions on policy outcomes. Moreover, because there is very little literature on the foreign economic policymaking of developing countries or non-democratic countries, institutional theories of foreign economic policymaking call for a synthesis of the role of institutions in general.

To a large extent, this study is a modest attempt to identify three institutional features, suggested explicitly or implicitly by existing literature, that are crucial to a country's foreign policymaking: the degree of insulation of the central policy makers from domestic interest groups, the degree of collective action within each domestic interest group, and the degree of fragmentation of the state power. One institution can have several of the features, and a country's political system is a complex of several kinds of institutions. It should be noted that this study does not hold a view that sees institutions as static but recognises the role of actors in creating and transforming institutions. Institutional change is crucial because it can bring about fundamental and long-lasting changes on policymaking and because institutions are often hard

\footnotetext{
${ }^{87}$ George Tsebelis, "Decision Making in Political Systems: Veto Players in Presidentialism, Parliamentarism, Multicameralism and Multipartyism," British Journal of Political Science (Jul. 1995): 289-325.

${ }^{88}$ A. Doak Barnett, Cadres, Bureaucracy, and Political Power in Communist China (New York: Columbia University Press, 1967).

${ }^{89}$ Lu, The Dynamics of Foreign-Policy Decisionmaking in China.

${ }^{90}$ For a review of new institutionalisms, see Thomas A. Koelble, "The New Institutionalism in Political Science and Sociology," Comparative Politics 27, no. 2 (Jan., 1995): 231-43.
} 
to change once certain interests or ideas are embedded. As will be discussed later, another task of this study is to suggest several sources of institutional change.

\subsubsection{Insulation [of the central policymakers]}

The degree of insulation of the central policymakers from domestic interest groups is an important institutional feature that determines policy outcomes. Regardless of the regime type, the more insulated the central policymakers are, the more likely they will adopt policies they perceive consistent with their conceptions of the national interest.

The relationship between the regime type and the degree of trade liberalization and cooperation has been one focus of institutional theories of foreign economic policymaking. ${ }^{91} \mathrm{~A}$ constant theme asserts that democracies cooperate more in international economic relations than autocracies do. One argument is that international trade agreements send a message to the domestic audience that the leadership will not support rent-seeking protectionist economic policies. ${ }^{92}$ That is based on the assumption, however, that the majority of voters agree (with economists) that trade liberalization is welfare enhancing, and the majority of them work for the industries that benefit from free trade. Another argument is that the same ideology and similar domestic political systems facilitate cooperation. Indeed, countries with the same ideology are more likely to cooperate than those with different ideologies, but the main reason may be to promote security alliance and the same reason can apply to pairs of autocracies. According to

${ }^{91}$ Michael Doyle, "Liberalism and World Politics", American Political Science Review 80 (December 1986): 1151-69. Geoffrey Garrett and Peter Lange, "Internationalization, Institutions, and Political Change", in Internationalization and Domestic Politics, edited by Robert O. Keohane and Helen V. Milner (New York: Cambridge University Press, 1996). Jeffry A. Frieden and Ronald Rogowski, "The Impact of the International Economy on National Policies: An Overview", in Robert O. Keohane and Helen V. Milner eds., Internationalization and Domestic Politics (New York: Cambridge University Press, 1996). Ronald Wintrobe, The Political Economy of Dictatorship (New York: Cambridge University Press, 1998). Paul Brooker, Non-Democratic Regimes: Theory, Government and Politics, (New York: Palgrave Macmillan, 2000). Daron Acemoglu and James Robinson, The Economic Origins of Dictatorship and Democracy: Economic and Political Origins (New York: Cambridge University Press, 2005).

${ }^{92}$ Edward D. Mansfield, Helen V. Milner, and B. Peter Rosendorff, "Why Democracies Cooperate More: Electoral Control and International Trade Agreements," International Organization 56, no. 3 (Summer 2002): 477-513. Richard K. Herrmann, Philip E. Tetlock, and Matthew N. Diascro, 'How Americans Think About Trade: Reconciling Conflicts among Money, Power, and Principles', International Studies Quarterly 45, 2 (2001): 191-218. James Fearon, 'Domestic Audiences and the Escalation of International Disputes’, American Political Science Review 88, 3 (1994):577-92. Anders Aslund, Peter Boone and Simon Johnson, "How to Stabilize: Lessons from Post-Communist Countries", Brookings Papers on Economic Activity 1 (1996): 217-311. Joan M. Nelson, "How Market Reforms and Democratic Consolidation Affect Each Other", in Joan M. Nelson, ed., Intricate Links: Democratization and Market Reforms in Latin America and Eastern Europe (New Brunswick, NJ: Transaction Publishers, 1994): 1-36. 
this argument, similar domestic systems facilitate cooperation because similar domestic regulation is easier for foreign businessmen to understand and reduces some transaction costs; however, in most cases, regulatory systems in democratic countries vary greatly too, and what foreign businessmen need most is a transparent and fair environment.

The picture of the 'democratic cooperation' argument is mixed if Putnam's two-level game is applied to trade negotiation between an autocracy and a democracy. Because the autocracy has a larger 'win set' - choices that can pass domestic ratification - than the democratic country, in principle, the autocracy has a weaker position at the negotiation table and therefore has to compromise more. Comparing cooperation between pairs of democracies and autocrats, Mansfield, Milner and Rosendorff find that when the preferences of the autocrats are protectionist relative to those of the legislature in the democracy, the pair of autocracies will be unable to lower barriers as much as the mixed pair, because the two autocracies do not have to contend with a legislature that is more protectionist than they are, they do not have to compromise as much. ${ }^{93}$ That gives part of the reason why China is asked to give more concession by Australia than by ASEAN in free trade negotiations; Australian negotiators present stronger argument than ASEAN that the government faces vociferous domestic objections if it allows China to keep certain barriers to trade.

Contesting the 'democratic cooperation' theory, others argue that domestic institutions in democracies render their leaders more susceptible to domestic protectionist pressures than those in autocracies do, because protectionist groups often lobby harder than pro-liberal groups. Democratic rulers tend to have shorter time horizons than their autocratic counterparts, since they must compete in regular, fair elections, but the benefits from trade reform often take some time to materialize and the costs tend to be felt much more quickly and concentrated. ${ }^{94}$ Autocratic states are more likely than their democratic counterparts to engage in international economic cooperation because the autocratic leadership is more insulated from domestic

\footnotetext{
${ }^{93}$ Edward D. Mansfield, Helen V. Milner, and B. Peter Rosendorff, "Free to Trade: Democracies, Autocracies, and International Trade," American Political Science Review 94, no. 2 (June 2000): 305-21. ${ }^{94}$ Frye and Mansfield, "Fragmenting Protection: The Political Economy of Trade Policy in the PostCommunist World." Stephan Haggard and Steven B. Webb, "What Do We Know about the Political Economy of Economic Policy Reform?" World Bank Research Observer 8 (1993): 143-67.
} 
demands, and can impose sacrifices on parts of the domestic economy. ${ }^{95}$ Yet, in autocracies, the leadership must also maintain political support, and some government officials may want to retain economic rents extracted from the protectionist policies, as the study of China will reveal.

The literature provides few suggestions as to how transitioning countries or countries between a mature democracy and a complete autocracy will behave, but numerous states exist in such a political status. A likely scenario is that because most non-democratic states are developing economies, their leaders may come to recognize that liberalization is a precondition for obtaining foreign capital, technology and markets, or they may be convinced that liberalization is good for the country's economic growth. Hence, their autonomy in policymaking varies with the degree of democratization and liberalization.

A conclusion has gradually been drawn in the debates whether democracies or autocracies cooperate more: not the regime type but the degree of insulation of the leadership is conducive to liberal economic policies, provided that the leadership prefers economic liberalization. It can be further argued that the insulation of the central policy makers - not necessarily the leadership from the pressure of domestic parochial interests bolsters foreign economic policies that are consistent with the national interest as perceived by the state. Assuming non-tariff barriers to trade (NTBs) are useful for enabling countries to maintain protection, Mansfield and Busch have found that NTBs are highest in large countries that are characterized by high levels of institutional insulation and autonomy. ${ }^{96}$ Like that in many other autocratic countries, the Chinese leadership is widely believed to be highly insulated in policymaking. Although according to the Constitution, the National People's Congress (NPC) is the supreme organ of power in China, the Politburo of the Central Committee of the Chinese Communist Party (CCP), led by the President and the Premier, has the de facto paramount power. ${ }^{97}$ However, it has been

\footnotetext{
${ }^{95}$ Milner, "The Political Economy of International Trade." Hiscox, "The Domestic Sources of Foreign Economic Policies." Katzenstein, "International Relations and Domestic Structures." Guillermo O'Donnell, Modernization and Bureaucratic-Authoritarianism: Studies in South American Politics (Berkeley: Institute of International Studies, University of California, 1973). Thomas Skidmore, "The Politics of Economic Stabilization in Postwar Latin America”, in James M. Malloy, ed., Authoritarianism and Corporatism in Latin America (Pittsburgh, Penn.: Pittsburgh University Press, 1977): 149-90. Stephan Haggard, Pathways from the Periphery: The Politics of Growth in Newly Industrializing Countries (Ithaca, NY: Cornell University Press, 1990), 262.

${ }^{96}$ Mansfield and Busch, "The Political Economy of Nontariff Barriers."

${ }^{97}$ Lu, The Dynamics of Foreign-Policy Decisionmaking in China. Feng, The Dragon Goes Global.
} 
widely recorded by China scholars that as China liberalizes its economy, more actors have entered foreign economic policymaking. Some sectors, such as heavy industries, launched recalcitrant resistance to policies inviting foreign competition before the WTO accession. Several authors have mentioned that the final decision to pursue GATT membership had to be made in a relatively centralized fashion so that it would not be blocked by opposition from industries. ${ }^{98}$ Hui Feng also notes that the policymaking of China's entry into WTO was a 'stateled, leadership-driven and top-down process', in combination with institutional arrangements to bypass reluctant bureaucracies. ${ }^{99}$

In a country with some degree of democratization in policymaking, insulation can be achieved through institutional arrangements that delegate power or distil information. Studies on the trade politics of democracies regard the relationship between the executive and legislature as most crucial, and therefore the delegation of power from the legislature to the executive promotes liberal trade policy, as for instance the US did to the president and to the Special Trade Representative through 'fast track' procedures. ${ }^{100}$ That is because legislators, who represent smaller constituencies than the chief executive, are more easily captured by special interests than the executive. ${ }^{101}$ By approving such procedures, the legislature reduced the pressure from lobby groups on the state, reduced log-rolling in the Congress, and even locked in liberal policies when the partisan majority was to change in the Congress. ${ }^{102}$ Michael Gilligan demonstrates that delegation did not exempt the Congress from constituency pressures, but replaced the universalistic logrolling in the congress with a desire to reduce foreign tariffs. ${ }^{103}$ In China, the locus of Chinese foreign economic policymaking authority has moved from the Central Party commissions to the State Council and ministries. Officially, the NPC delegates the power of negotiating international economic agreements to the executive. One important

\footnotetext{
${ }^{98}$ Shirk, How China Opened Its Door. Wang, "China's Domestic WTO Debate." Fewsmith, "China and the WTO." Pearson, "The Case of China's Accession to GATT/WTO."

${ }^{99}$ Feng, The Dragon Goes Global.

${ }^{100}$ Destler, American Trade Politics. Destler, 1992; Milner, "The Political Economy of International Trade."

${ }^{101}$ Milner, "The Political Economy of International Trade."

102 Susanne Lohmann and Sharyn O'Halloran, "Divided Government and Us Trade Policy: Theory and Evidence," International Organization 48, no. 4 (Autumn 1994): 595-632.

${ }^{103}$ Michael J. Gilligan, Empowering Exporters: Reciprocity, Delegation, and Collective Action in American Trade Policy, Michigan Studies in International Political Economy (Ann Arbor: The University of Michigan Press, 1997).
} 
question here is whether international treaties negotiated by the executive need to be ratified by the legislature before they come into force in a country. In China, the NPC's activity has increased in areas of domestic policies, but arguably is still very limited in foreign and foreign economic policymaking. Only important international treaties are sent to the NPC for approval, if judged necessary by the government. ${ }^{104}$

Delegation does not have to be granted to the chief executive; it can also be granted to a special office in the government or a spontaneously created working group. As Stephan Haggard and Steven Webb have noted about trade liberalization in numerous developing countries, "[i]n every successful reform effort, politicians delegated decision-making authority to units within the government that were insulated from routine bureaucratic processes, from legislative and interest group pressures, and even from executive pressure." 105 An inter-agency ad hoc decision-making body, the Central Leading Group for WTO Affairs headed by Wu Yi, played such a decisive role in China' accession process into the WTO. ${ }^{106}$ Similarly, the Central Financial Working Group was formed by Zhu Rongji to propel financial reforms in the late 1990s. Because MOFCOM is the main government agency in charge of foreign trade and investment policy in the Chinese central government, it is reasonable for the Chinese government to form a working group on these policy issues with MOFCOM as the leading agency, together with other ministries whose inputs are needed. Such groups are normally formed by the State Council, but naturally the State Council cannot deal with numerous specific policies; therefore often the responsibility belongs to MOFCOM to coordinate policies among ministries. There is a question, however, of how effective MOFCOM can play that role, as will be discussed through case studies.

\footnotetext{
${ }^{104}$ Rengang Huang, "How Has Accession to the WTO Changed Trade Policy Making in China?" the Workshop on Trade Policymaking in Developing Countries, the London School of Economics and Political Science, 25 May 2005. Murray S. Tanner, "The National People's Congress," in The Paradox of China's Post-Mao Reforms, ed. Merle Goldman and Roderick MacFarquhar, Harvard Contemporary China Series; 12 (Cambridge, Mass.: Harvard University Press, 1999), 100-28. Sheng, The Political Economy of China's Foreign Trade Policies, 252-69.

${ }^{105}$ Stephan Haggard, Steven Benjamin Webb, and World Bank., Voting for Reform: Democracy, Political Liberalization, and Economic Adjustment (New York: Published for the World Bank, Oxford University Press, 1994).

${ }^{106}$ Huang, "How Has Accession to the WTO Changed Trade Policy Making in China?" Feng, The Dragon Goes Global. Pearson, "The Case of China's Accession to GATT/WTO."
} 
Insulation of policymaking power can also be achieved through institutional arrangements that distil information. If domestic groups are not aware of what policies are under discussion in the government, or what implications the policies would have, they are less likely to monitor or lobby the government. Many trade agreements would have been blocked by domestic opposition if the governments had not kept the preparation or negotiation details confidential. Financial policies are more complicated and sensitive for state economic security than trade policies; therefore the Central Bank and other monetary authorities are easier to be insulated in foreign financial policy making. For trade policies, some governments ask for opinions from the business community before commencing negotiations, while others restrict the information to a few major stake holders whose information is needed for negotiation and whose approval is needed for the agreement to be effective. Through institutional arrangements, information can be channelled and distilled so that it creates favourable feedbacks to the government position. The need of foreign economic policymaking for expertise can be the excuse that the state leadership uses to delegate power to technocrats or scholars who hold the same policy preferences as the leadership. An increasingly routine procedure before formal free trade negotiations is to commission a feasibility study from experts within each country or from a group formed jointly by the two countries. The positive results from the feasibility study are usually used by the states to confront domestic protectionist oppositions. The feasibility studies of China's FTAs are delegated to various think tanks and academic institutions, some of which are affiliations to the government or have close internal communications with the government. In fact, the information is usually not public on which organization the government has commissioned the study to.

\subsubsection{Collective action [of domestic interest groups]}

The degree of collective action within each domestic interest group (in democratic countries, or policy coalition in non-democratic countries) affects its influence on the central policymakers. The more a domestic group acts collectively, the greater the influence it has on the central policymakers to choose a policy in their favour, either because the central policymakers are persuaded of its consistence with the national interest or because they had to 
accommodate those interests for political survival. The institutional characteristics of each group and of the state have decisive impacts on the degree of collective action of domestic groups, because different institutions aggregate or disperse preferences in different ways.

Parallel to constructivism in international relations theory, social institutionalism holds that actors within the same social environment develop shared interests and beliefs because interests are a social construction and follow the 'logic of appropriateness' ${ }^{107}$ It is true that norms, culture and shared interests develop within institutions, and actors within an economic institution share interests also because they rely on the same source of income, but why do domestic groups differ vastly in their internal cohesiveness, as demonstrated by the degree of collective action in policymaking? Within the same national policymaking environment, why do so many conflicting interests still persist? The organizational form differs from institution to institution, apart from the varied economic and political relations among the members and their political awareness. These differences lead to varying degrees of collective action among domestic groups, which affects their influence on policymaking.

The degree of collective action is central to theoretical explanations of the variation in the influence of domestic interest groups on the government in democratic countries. It is difficult for a government to adopt liberal economic policies as required by international economic cooperation because the government is often captured by domestic protectionist groups, who have less collective action problem than the consumers. I.M. Destler explains the post-war liberal trade policies by reference to a national political environment conducive to liberalization, in which interest group initiative was limited and followed a simple pattern. ${ }^{108}$ Jeffry Frieden attributes the unstable policies of the US in the interwar period between insularity and internationalism to the uneven distribution of international interests within the American society. ${ }^{109}$ Theories of trade politics (endogenous tariff theory in particular) dichotomize the economic interests of special interest groups, which demands protection through rent-seeking or lobbying, and those of the wide electorate, which benefits from welfare enhancement brought

\footnotetext{
${ }^{107}$ Walter W. Powell and Paul J. Di Maggio, eds., The New Institutionalism in Organizational Analysis (Chicago: University of Chicago Press, 1991). Mark Granovetter and Richard Swedberg, eds., The Sociology of Economic Life (Boulder: Westview Press, 1992).

${ }^{108}$ I. M. Destler, American Trade Politics, 173.

${ }^{109}$ Frieden, "Sectoral Conflict and U.S. Foreign Economic Policy, 1914-1940."
} 
by economic liberalization. In recent literature, more attention has been paid to domestic interest groups that benefit from liberal trade. Overall, policy makers find themselves in a dilemma to react to the demands of both protectionist and liberal groups (including pro-liberal special interest groups and the consumers) in order to win elections; their choice depends on the relative force of each group.

Whose interest will the government accommodate, protectionist or liberal domestic groups? An adage tells that governments usually pick prospective losers over winners. This is especially conspicuous in trade policy choices: sunset industries often win a disproportionate share of government support although they have limited capability to finance lobbying and they pay decreasing tax to the government, if not the major source of government budget deficits. The political economy literature gives several reasons for this 'losers' paradox'. First, benefits to social welfare from economic liberalization are widespread, whereas costs to some domestic groups are concentrated and thus change in the income of losing groups is more significant.

Second, gains for exporters from liberalization take time to be realized and are uncertain because of the nature of international competition, whereas losses for import-competing sectors are immediate and predictable. ${ }^{110}$ Third, in an expanding industry, policy-created rents attract new entrants that erode rents because of free riding. In ailing industries, sunk market-entry costs allow protection to raise profits without attracting entry. ${ }^{111}$ All these factors lead to the result that losers have less of a collective action problem and lobby harder for protection than winners do for liberalization. ${ }^{112}$ Because "for a politician who must respond to concentrated interests, a vote for lowering trade barriers is... an 'unnatural act"', the government chooses policies favoured by the losers. ${ }^{113}$ Explaining the US's trade liberalization after 1934, Gilligan argues that the power delegated to the US president to negotiate reciprocal trade agreements has led exporting industries to overcome collective action problems and to strengthen their lobbying on the

\footnotetext{
${ }^{110}$ Judith Goldstein and Lisa L. Martin, "Legalization, Trade Liberalization, and Domestic Politics: A Cautionary Note," International Organization 54 (Summer 2000): 219-48.

${ }^{111}$ Richard E. Baldwin and Frederic Robert-Nicoud, "Entry and Asymmetric Lobbying: Why Governments Pick Losers," National Bureau of Economic Research Working Paper, no. 8756 (2002)

${ }^{112}$ Mancur Olson, The Logic of Collective Action: Public Goods and the Theory of Groups, Harvard Economic Studies, V. 124 (Cambridge, Mass., Harvard University Press, 1965).

${ }^{113}$ Destler, American Trade Politics, 5.
} 
government to reduce domestic tariffs in exchange for their access to foreign markets. The institutional arrangement thus empowered exporters. ${ }^{114}$

In countries in transition, the degree of collective action within domestic constituencies (including industries and local governments) is often associated with the amount of rents generated from the regulatory institution. The more rents that government officials can obtain from the sector or province of which they are in charge, the more incentive they have to speak for the constituency in state-level policy making at the risk of conflicting with central policymakers. There is often a real fear that the bureaucratic agencies that implement trade policies and laws may develop a too cosy relationship with the domestic sectors that they are supposed to regulate. ${ }^{115}$ Shirk found that the selectivism of China's reform policies, which translated into patronage opportunities, suited the incentives of communist leaders who were competing for the support of subordinate officials. ${ }^{116}$ It is one important reason why the Chinese ministries in charge of industries that are likely to be affected by imports request protectionist trade policies.

Apart from a group's material interests, the degree of collective action within each domestic group is also affected by its members' political awareness, which is in turn affected by institutions. Institutions affect political awareness by constraining political participation and distilling information. In China, there is no independent labour union or farmers' union because of the restrictive policies of the Communist Party. ${ }^{117}$ The workers are scattered in industries and associate their interests with the enterprises they work for. Collective bargaining, strikes and protests are much constrained. Chinese farmers are mostly concerned with their household livelihood and have little knowledge of foreign economic policies whatsoever. Consumers have a similar low level of knowledge. The political system in the PRC has made the public much less enthusiastic in political participation than those in democratic systems. This is not to say, however, that social tension and conflicts do not exist in China. As a matter of fact, the tension over social welfare and income imbalance has become increasingly serious in recent years, as

\footnotetext{
${ }^{114}$ Gilligan, Empowering Exporters: Reciprocity, Delegation, and Collective Action in American Trade Policy.

${ }^{115}$ Hiscox, "The Domestic Sources of Foreign Economic Policies."

116 Shirk, How China Opened Its Door.

${ }^{117}$ Yahuda, "How Much Has China Learned About Interdependence?"
} 
reflected in the government's new jargon of 'constructing a harmonious society'. The resentment in the public has not been directed towards specific foreign economic policies, but may constrain the government's decision on certain policies, as will be discussed in the case studies. The business associations in China are at an initial stage of development; many are still closely associated with the government. They are still having difficulty in making domestic firms more aware of what opportunities a certain foreign economic policy may provide, not to mention forming policy coalitions among different industries.

\subsubsection{Fragmentation [of state power/government]}

Fragmentation of state power is directly related to the difficulty of achieving consensus among ministries and local governments. The more the state power is fragmented in policymaking, the more difficulty there is to ratify a policy initiative. Horizontal fragmentation exists among ministries, the legislature and other government organs at the state level; vertical fragmentation exists between the central and local governments. As Margaret Pearson comments, China's bureaucracy has become vulnerable to political influence, not so much from society but from sectors within the government. ${ }^{118}$ 'Fragmented authoritarianism' is captured by several depictions of bureaucratic politics in China, referring to the complex process of bureaucratic bargaining and consensus building in Chinese policymaking. ${ }^{119}$

The number of 'veto players' is a reflection of the degree of horizontal fragmentation of the policymaking power. As defined by Tsebelis, veto players are individual or collective actors whose agreement is required for a change of the status quo. The potential for policy change decreases with the increase in the number of veto players and the dissimilarity of policy positions among veto players. ${ }^{120}$ Henisz and Mansfield have a similar argument, only referring to Tsebelis' veto players as 'veto points'. ${ }^{121}$ In this sense, Chinese Premier Zhu Rongji's institutional reform in 1998 was largely an act of cutting veto points, or undermining veto

\footnotetext{
${ }^{118}$ Margaret M. Pearson, "China's WTO Implementation in Comparative Perspective: Lessons from the Literatures in Trade Policy and Regulation," The Review of International Affairs 3, no. 4 (Summer 2004): $567-83$.

${ }^{119}$ Kenneth G. Lieberthal and David M. Lampton, eds., Bureaucracy, Politics, and Decision Making in Post-Mao China (Berkeley: University of California Press, 1992). Pearson, "The Case of China's Accession to GATT/WTO."

${ }^{120}$ Tsebelis, "Veto Players."

${ }^{121}$ Henisz and Mansfield, "Votes and Vetoes."
} 
players, in order to propel liberal economic policies. In Zhu Rongji's time, MOFTEC was in charge of foreign economic issues, while the Committee of Economy and Trade (CET) under the State Council was in charge of both domestic and foreign economic issues, and the Central Planning Commission in the Party system was in charge of domestic macro-economic policies. The CET officially had a higher rank than MOFTEC, and was the usual venue for domestic opposition to be expressed. When MOFTEC was restructured to MOFCOM in 2003, the CET was abolished, and the Central Planning Commission was restructured to the National Development and Reform Commission (NDRC) to reflect the state's determination of making China a market economy. ${ }^{122}$ Some of their functions were merged into MOFCOM, so that the Chinese government could better coordinate domestic and foreign economic policies. This could mean a shorter route for domestic actors to put pressure on the central government, or it could make it easier for international considerations to override domestic interests. ${ }^{123}$ Empirical investigation is needed about its implications for Chinese foreign economic policymaking and policies on regional economic cooperation. Moreover, several industrial ministries are downgraded into bureaus or business associations because they were the core of the planned economic system. ${ }^{124}$

Vertical fragmentation of the state power refers to the participation of local governments in state-level policymaking. In democratic countries, local interests are represented by elected legislators; the relationship between the central and local governments in federal systems is clearly defined in law. Contrary to the portrayal of a personalistic and centralized Chinese policymaking, several authors have argued that decentralisation was a dominant characteristic after 1978. ${ }^{125}$ David Lampton identifies decentralisation as one of the four major trends of Chinese foreign policymaking in the era of reform, together with professionalization, corporate

\footnotetext{
${ }^{122}$ The NDRC was intended only to play an advisory role in China's economic policymaking, but its power has grown significantly in the Hu-Wen government.

${ }^{123}$ In some other countries such as Australia and South Korea, the departments in charge of foreign economic policy is merged with the department in charge of foreign affairs, reflecting the state's aim to better coordinate national economic and strategic interests in foreign economic policymaking.

${ }^{124}$ Pearson, "China's WTO Implementation in Comparative Perspective."

${ }^{125}$ See, Carol Lee Hamrin and Suisheng Zhao, eds., Decision-Making in Deng's China: Perspectives from Insiders (Armonk; London: East Gate Book, 1995). Cheung and Tang, "The External Relations of China's Provinces." Medeiros and Fravel, "China's New Diplomacy." Shirk, How China Opened Its Door.
} 
pluralization and globalization. ${ }^{126}$ The economic power and global linkages of regional and local authorities in the process of internationalization have undermined to a considerable degree the authority of the central state. ${ }^{127}$ Provincial leaders have become increasingly assertive in voicing their interests, especially those of inland poor provinces about concerns over regional economic disparity. ${ }^{128}$ Gabriella Montinola, Yingyi Qian and Barry Weingast even argue that the increased devolution of power from the centre to the regions has produced a market-preserving form of federalism in China. ${ }^{129}$

Alternatively, Lieberthal and Lampton, and Carol Hamrin and Suisheng Zhao, think the nature of Chinese politics differs at various levels of the system: high-level decision making is non-routine and personalistic; mid-level administration embodies the interaction of personalistic and routine bureaucratic politics; and, low-level implementation plays a feedback role with possible policy dilution. ${ }^{130}$ One focus of this study is to investigate to what extent Chinese foreign economic policymaking is centralized or decentralized. Another question related to China's policymaking on regional economic cooperation is whether WTO accession has strengthened the centre vis-à-vis the provinces. Theoretically, WTO membership requires, and empowers, the central government to adopt a series of policies that overwrite local regulations, reasoning that it is obliged to comply with WTO rules, a logic that would also apply to regional trade agreements. One important question here is whether regional economic cooperation has been used by the central government to promote local liberalization and reforms, because this is one argument by proponents of regionalism that regionalism promotes global economic liberalization. Empirical study on this question is needed in order to know the centre-local relationship in recent Chinese foreign economic policymaking, as well as what role this relationship played in the formulation of regional cooperation policies.

\footnotetext{
${ }^{126}$ Lampton, ed., The Making of Chinese Foreign and Security Policy, 4-27.

${ }^{127}$ Harris, "Globalisation and China's Diplomacy." Cheung and Tang, "The External Relations of China's Provinces."

${ }^{128}$ Dali L. Yang, "The Dynamics and Progress of Competitive Liberalization in China," Issues \& Studies 32, 8 (1996): 13 .

${ }^{129}$ Montinola, Qian, and Weingast, "Federalism, Chinese Style: The Political Basis for Economic Success."

${ }^{130}$ Lieberthal and Lampton, Bureaucracy, Politics, and Decision Making in Post-Mao China. Hamrin and Zhao, eds., Decision-Making in Deng's China.
} 
Local governments have influence over state-level policymaking also because many economic policies - especially 'behind-the-border' issues - need to be carried out at the local level. Lisa Martin suggests that partial implementation can be used as an ex post limitation by the executors of policy on the actions of the policy makers. ${ }^{131}$ Local protectionism, lack of policy transparency, corruption, local discriminatory regulations, and fragmentation of the Chinese domestic market constrain the effectiveness of central policies and are usual targets of complaint from foreign firms about doing business in China. Local Chinese officials often invoke the traditional aphorism that "those above have their policies, we below have our countermeasures" (shang you zhengce, xia you duice). That is partly because functional implementation agencies, such as local copyright, patent, and trademark offices, are beholden to their local governments and not to their national-level counterparts for personnel, budgetary, and other resource allocations. The Chinese central government is fully aware that partial or delayed implementation by local governments in effect sabotages international treaties. On the one hand, the prospect of partial implementation allows the Chinese government to make more ambitious commitments at international negotiations than they can actually realize, thus giving Chinese negotiators advantage over other countries. Peter Cheung et al. correctly point out that the Chinese institutions allow for flexibility and fine-tuning at the provincial level because the provincial government is often given the discretion to decide on the details and schedule of implementation. ${ }^{132}$ On the other hand, if the central government wants certain foreign economic policies to be effective, they need to take local opinions into consideration, whether or not through direct consultation with local governments. The same is true with industrial ministries: many foreign economic policies - except tariff and foreign trade quota, or border issues - are made by MOFCOM and approved by the State Council but need industrial ministries to put them into action. Therefore, MOFCOM has to consult with industrial ministries before deciding on policies that have significant implications for these industries.

In summary, to study the role of institutions in structuring the interactions and formulation of policy preferences, one needs to look beyond formal institutional structures (like

\footnotetext{
${ }^{131}$ Lisa Martin, Democratic Commitments: Legislatures and International Cooperation (Princeton: Princeton University Press, 2000).

${ }^{132}$ Cheung, Chung, and Lin, eds., Provincial Strategies, 14.
} 
the regime type) and analyze the underlying institutional configuration. Three institutional features may be important in affecting policy outcomes and therefore how these features affect policy outcomes will be a major topic of discussion in the case studies. The first is the degree of insulation of central policymakers from domestic interest groups; insulation may be achieved through delegation of power or the control of information. The second is the degree of collective action within each domestic interest group. It is worth studying whether prospective losers or winners have a higher degree of collective action, and whom the government pick. The amount of rents and the extent of formal organization may also affect the degree of collective action. The third is the degree of fragmentation of state power, including horizontal fragmentation among central government agencies and vertical fragmentation between the central government and local governments.

\subsection{Institutional change}

Institutional change has a significant impact on policy outcomes because it redistributes power and resources, changing the dynamic interactions among policy preferences. Such developments also signify the institutionalization of interests and ideas. Institutional development is one of the most important subjects of inquiry for institutional theorists. Important questions are: how does institutional change happen, and how does it influence policymaking?

Many theories hold that old institutions are not easy to change because embedded culture and interests will normally resist the costs and uncertainty associated with change. Examples are Allison's organizational behaviour model, social institutionalism, and historical institutionalism, as will be introduced in greater detail in the next section. Apart from the different levels of collective action within domestic groups, governments accommodate the opposition of losers against trade liberalization because changes from the status quo sometimes require explicit affirmation by prospective losers (but not by winners), and therefore those who benefit from the status quo gain veto power. ${ }^{133}$

${ }^{133}$ Goldstein and Martin, "Legalization, Trade Liberalization, and Domestic Politics." 
That assertion holds some truth in Chinese domestic politics. In China, opposition against further reform comes not only from the sectors that benefit from the existing system, but also from conservatives commenting on the costs hitherto associated with globalization on the domestic economy (the demise of state-owned enterprises, income inequality, unemployment, etc.). Like the post-communist countries, the institutional legacy of a command economy still bears heavily on China's foreign economic policy. Many regulations lack transparency, the complicated licensing procedures induces corruption, and state monopoly still exists in many sectors. Those were part of the reason why there was a lot of hesitation and debate in Australia before the government recognized China as a market economy in order to start free trade negotiations. As will be discussed in the case study, the different ways of thinking between a command economy and a market economy started to surface and created problems soon after China and Australia started bilateral free trade negotiations.

Studies on economic reform suggest that winners gain political power from initial reforms vis-à-vis the protectionists, and thus they have the incentive and means to push reform further. ${ }^{134}$ For instance, Frye argues that in non-democracies new elites with weak ties to the old regime use trade liberalization as a weapon against their political opponents. The dispersion of state power is likely to promote liberalization by giving groups with a preference for free trade greater ability to push for policies that will serve their interests. ${ }^{135}$ One question is whether beneficiaries of economic liberalization in China are able to push liberalization further, not only in their sectors but also in other sectors, in order to achieve their aims in a package of international agreement. For instance, Susan Shirk recorded that upon the prospective entry of China into the GATT, domestic textile manufacturers were thrilled by the opportunity of expanding their export markets, but the textile industry had little clout in policymaking. Because of a traditionally skewed industrial policy under the Soviet-style command economy, the regime's legitimacy relied largely on heavy industries such as machinery and electronics, which

\footnotetext{
134 John McMillan and Barry Naughton, Reforming Asian Socialism: The Growth of Market Institutions (Ann Arbor: University of Michigan Press, 1996). Stephan Haggard and Robert R. Kaufman, eds., The Politics of Economic Adjustment (Princeton: Princeton University Press, 1992). John Williamson, ed., The Political Economy of Policy Reform (Washington, D.C.: Institute for International Studies, 1994).

${ }^{135}$ Frye and Mansfield, "Fragmenting Protection: The Political Economy of Trade Policy in the PostCommunist World."
} 
feared competition with imported home appliances and automobiles and tried to block the WTO entry. ${ }^{136}$

Another question is whether winners from initial reform are willing to push reform further. In contrary to the view that empowering winners from economic liberalization can strengthen the liberalization process, partial reform can also give winners incentives to keep the status quo. Joel Hellman argues that political systems that concentrate more power in the hands of the winners are more likely to preserve partial reforms over time. That is because further progress in reform threatens to eliminate the special advantages and market distortions upon which the winners' early gains were based. Besides, the winners with their concentrated gains would be expected to play a more decisive role, given their greater resources, their smaller number, and their selective incentive for collective action. ${ }^{137}$ Authors who accept this argument therefore believe that for reforms to succeed in developing countries, either a full-scale immediate liberalization should be implemented, or in partial reforms, those who benefit from liberalization should have more power than the protectionist sectors and should expect more gains from further liberalization to continue the momentum of reform.

In studies of economic liberalization in developing countries including China, rentseeking behaviours are widely acknowledged to impede the move from partial reforms to full liberalization. The particularistic power of government officials over the market - such as granting licences and quota - has created huge amounts of rents for themselves and for their bureaucratic agencies, and has led to a culture of business-government interdependence and corruption. Whether those government officials represent protectionist or liberal factions of the economy, they are likely to prefer the status quo to uncertainties associated with future changes, and prefer personalistic decision making to legalization and standardization. ${ }^{138}$

\footnotetext{
${ }^{136}$ Shirk, How China Opened Its Door. Also see the previously mentioned literature on China's domestic policymaking of the WTO accession.

${ }^{137}$ Joel S. Hellman, "Winners Take All: The Politics of Partial Reform in Postcommunist Transitions," World Politics 50, no. 2 (1998): 203-34.

${ }^{138}$ Shaun Breslin, "Paradigm Shifts and Time-Lags? The Politics of Financial Reform in the People's Republic of China," Asian Business \& Management 2 (2003). Susan L. Shirk, The Political Logic of Economic Reform in China, California Series on Social Choice and Political Economy; 24 (Berkeley: University of California Press, 1993). Barry Naughton, "China's Transition in Economic Perspective," in The Paradox of China's Post-Mao Reforms, ed. Merle Goldman and Roderick MacFarquhar, Harvard Contemporary China Series; 12 (Cambridge, Mass.: Harvard University Press, 1999), 30-44
} 
Given the resistance of existing institutions, how can institutional change happen? Many theorists have pointed to crisis as the stimulus for change. ${ }^{139}$ One kind of model emphasises external shock. According to Goldstein, in periods of external shock, the conditions of not only the disadvantaged actors but also the embedded interests in the old system are worsened, and the doubt on the old system is so overwhelming that radical changes become possible in urgent need of solution, and therefore the state structures become malleable. Another kind of model stresses the internal tension built over time. According to Stephen Krasner's 'punctuated equilibrium, ${ }^{140}$ internal tensions between the practical demands and the ability of institutions created in the old conditions accumulate in a relatively stable phase, until old institutions cannot sustain the tension anymore and crisis breaks out, leading to significant changes and another circle of plateau and crisis. Lawrence Reardon records the pre-reform history of Chinese foreign economic policymaking as crisis cycles, whereby one ideology, together with institutions that embodied this ideology, dominated until it developed into extremism and conflicted with pragmatic needs, leading to its replacement by another set of ideology and institutions. ${ }^{141}$

In both crisis-driven models, institutional change was essentially the result of qualitative change of actors' preferences. However, crises do not happen frequently to countries, whereas institutional changes have been evident in normal times, as demonstrated by Peter Hall. ${ }^{142}$ During the reform-era since 1978, China's foreign economic policy has generally been developed in the direction of reform and liberalization as a legacy of Deng Xiaoping, and its policymaking institutions have changed significantly. The existing literature as mentioned above has not provided much answer to how institutions change under stable conditions without the fundamental change of actors' preferences. In the next section, the conceptual framework

\footnotetext{
139 Judith Goldstein, "The Impact of Ideas on Trade Policy: The Origins of U.S. Agricultural and Manufacturing Policies," International Organization 43, no. 1 (Winter 1989). Frieden, "Sectoral Conflict and U.S. Foreign Economic Policy, 1914-1940."

${ }^{140}$ Stephen D. Krasner, "Approaches to the State: Alternative Conceptions and Historical Dynamics," Comparative Politics 16, no. 2 (Jan. 1984): 223-46.

${ }^{141}$ Lawrence Reardon, The Reluctant Dragon: Crisis Cycles in Chinese Foreign Economic Policy (Seattle and London: University of Washington Press, 2002).

${ }^{142}$ A good example is Peter A. Hall, "The Movement from Keynesianism to Monetarism: Institutional Analysis and British Economic Policy in the 1970s," in Structuring Politics: Historical Institutionalism in Comparative Analysis, ed. Sven Steinmo, Kathleen Ann Thelen, and Frank Longstreth, Cambridge Studies in Comparative Politics (Cambridge [England]; New York: Cambridge University Press, 1992), 91-113.
} 
will suggest a few possible sources for institutional change, apart from the discussion on some important features of institutions.

In short, while it is important to study the role of institutions in structuring the formation of and interactions among policy references, it is also important to study the possibilities of institutional change. First, it is worth investigating to what extent institutions resist change, in particular in China whether partial reform is conducive to further change. Second, potential sources of institutional change need to be identified. The following section will discuss some possible sources of institutional change in China's policymaking on regional economic cooperation.

As discussed in the previous sections, existing literature shows that foreign economic policymaking - of regional economic cooperation in particular- involves the choice among various domestic interests, national economic and strategic interests, and ideas about what policy objectives to pursue and how to pursue them. A plethora of interests and ideas enter the policymaking process together as policy preferences, and try to convert or prevail over others. Their interactions are channelled and structured by policymaking institutions. Which preferences will be embodied in policy outcomes is largely decided by institutions, which are created and transformed by political actors within historical constraints. As will be discussed in the following section, this way of conceptualizing foreign economic policymaking agrees with historical institutionalism. From this angle, the next section will map out the conceptual framework of the study.

\section{Conceptual framework}

\subsection{Why historical institutionalism for foreign economic policymaking?}

In a review of 'new institutionalisms' in political science and sociology, namely rational choice institutionalism (similar to new institutional economics), sociological institutionalism and historical institutionalism, Thomas Koelble comments that historical institutionalism is extraordinarily useful in the analysis of policymaking and institutional development, which are 
the very focus of this thesis. ${ }^{143}$ As discussed in the above sections, foreign economic policymaking theories call for a synthesized model to bring together various preferences consisting of interests and ideas at the domestic and state levels - and analyze the linkages among them as well as linkages between factors in policymaking and policy outcomes. For this endeavour, historical institutionalism provides a comprehensive and synthesized framework for exploring those linkages in policy making, with institutions at the centre both as the constraint on political interactions as well as the outcome thereof. In this study I will adopt Peter Hall's widely accepted definition of institutions as "the formal rules, compliance procedures, and standard operating practices that structure the relationship between individuals in various units of the polity and economy.",144

One feature typifying historical institutionalism is its emphasis on the 'relational character' of institutions. It highlights the role of institutions in structuring the interplay of interests and ideas, as Hall succinctly summarizes: ${ }^{145}$

Institutional factors play two fundamental roles in this model. On the one hand, the organization of policy-making affects the degree of power that one set of actors has over the policy outcomes.... On the other hand, organizational position also influences an actor's definition of his own interests, by establishing his institutional responsibilities to other actors. In this way, organizational factors affect both the degree of pressure an actor can bring to bear on policy and the likely direction of this pressure.

However, historical institutionalism stops short of specifying how institutions distribute power among policy preferences and influence actors' preferences. ${ }^{146}$ It is more an analytical approach than a specific theoretical proposition. As Sven Steinmo et al. point out, what has been missing is more explicit theorising on the reciprocal influence of institutional constraints and political strategies and, more broadly, on the interaction among ideas, interests, and institutions.

\footnotetext{
${ }^{143}$ Koelble, "The New Institutionalism in Political Science and Sociology."

${ }^{144}$ Peter Hall, Governing the Economy: The Politics of State Intervention in Britain and France (New York: Oxford University Press, 1986), 19.

145 Ibid.

${ }^{146}$ Sven Steinmo, Kathleen Ann Thelen, and Frank Longstreth, Structuring Politics: Historical Institutionalism in Comparative Analysis, Cambridge Studies in Comparative Politics (Cambridge [England]; New York: Cambridge University Press, 1992).
} 
Another feature of historical institutionalism - as it is called 'historical' - is that it emphasises the organizational culture and the path-dependent 'stickiness', or inertia, of institutions, that is, the tendency to resist change. As pointed out earlier, institutions do tend to keep status quo because of culture, norms, rents, and actors' fear of costs and uncertainty associated with change. The contention within historical institutionalism resides in the degree of inertia of institutions and the likelihood of change. As historical institutionalism looks for connections over time and views institutions as the (conscious or unintended) product of deliberate political strategies, of political conflict and of choice, ${ }^{147}$ it recognises the probability and significance of institutional change.

\subsection{The 'how' questions}

To the first question, namely, how institutions structure the interactions among policy preferences (including interests and ideas), I proposed in a previous section to study three underlying institutional configurations - the degree of insulation of the central policymaker, the degree of collective action within each domestic interest group, and the degree of fragmentation of state power. The major task of the case studies is to examine whether and how those three institutional features have influenced China's policies on regional economic cooperation.

This study will also explore sources of institutional change because it affects the dynamics of interactions among policy preferences. To the second question on how institutions change, the starting point for my analysis is that institutions indeed have some resistance to change because of vested interests or embedded ideas, which constrains future institutional change. It may be adequate to say that political actors cannot create or modify institutions freely as the rational institutionalists assume, but their hands are not totally bound by existing institutions. Institutional changes occur because of material, ideational or contextual changes, and in turn have major impacts on political interactions in policy making and policy outcomes.

This study will look for the sources of institutional change under stable settings like the reform-era China. Three sources of institutional change are highlighted here: 'institutional

\footnotetext{
${ }^{147}$ Kathleen Thelen and Sven Steinmo, "Historical Institutionalism in Comparative Politics," in Structuring Politics: Historical Institutionalism in Comparative Analysis, ed. Sven Steinmo, Kathleen Ann Thelen, and Frank Longstreth (Cambridge [England]; New York: Cambridge University Press, 1992), $1-32$.
} 
learning', the emergence of a new policy area and a change in the composition of key actors.

Certainly they should not be regarded as an exhaustive list, but possible mechanisms or conditions that are conducive to institutional change.

\subsubsection{Institutional learning}

Many institutions in the world have similar forms not only because they suit certain rational needs of actors in similar environments, but also because they assimilate through 'imitation' and 'coordination'. ${ }^{148}$ Faced with complicated situations arising from globalization and industrialization, policymakers are often unclear which the best arrangement is. The easy way is to borrow institutional forms from other countries based on the logic that since those institutions have been in existence for a while, they may be the tested best choice. Then these institutions and home conditions adapt to each other. At the domestic level, the foreign economic policymaking institutions of developing countries have converged to a great extent by imitating more advanced economies, and to accommodate demands placed on them by the latter and by the various processes of globalization.

At the international level, apart from the policymakers' learning of ideas, learning by regional institutions is also part of the 'demonstration', 'emulation' and 'contagion' effects of one regionalism on another. ${ }^{149}$ Institutional learning also happens when the institutions of two countries engaged in cooperation interact with each other and find the need to systematise and streamline transactions, reduce principal differences, clarify policies and reduce transaction costs. In this sense, in international economic cooperation, the need of coordination facilitates similar institutions to emerge across national boundaries. Moreover, the economic activities of firms have globalized to such an extent that liberalization at the national borders is not enough to satisfy their needs; however, the multilateral negotiation at the WTO has not made substantial progress on behind-the-border issues.

Institutional change happens not only in the implementation of regional economic cooperation, but also in the policymaking stage. That is because the governments need to make joint decisions and set concerted agenda. Regional free trade negotiation is such a venue for

\footnotetext{
${ }^{148}$ Douglass C. North, Institutions, Institutional Change, and Economic Performance (Cambridge: Cambridge University Press, 1990): 21, 37.

${ }^{149}$ Ravenhill, "Regionalism."
} 
national policymakers to coordinate their respective domestic systems. As a result, similar policymaking institutions of regional economic cooperation are likely to arise among participating countries as part of their foreign economic policymaking system. One question that this thesis will investigate is to what extent China's regional economic cooperation has had such an effect on Chinese domestic institutions.

\subsubsection{A new policy area}

The emergence of a new policy area provides good opportunities for new institutions to be created. New policy issues often require policymakers to make institutional innovations or ad hoc arrangements to meet new demands, and these working arrangements are possible to develop into formal institutions over time. Destler has found such developments in trade policymaking of the US. ${ }^{150}$

To what extent the policy area needs to be different from existing ones so that it can be called 'new' is sometimes defined by policymakers themselves. In other words, policymakers may be able to overcome old institutional constraints and develop new institutions by defining a policy issue as "new". During a country's economic reform and liberalization, many such opportunities come up. As a departure from the personalistic character of policymaking in prereform China, institutionalization is identified as one of the trends in China's foreign economic policymaking during reform and opening. ${ }^{151}$ Many ‘Central Working Leading Groups’ have been formed since the founding of the PRC to deal with important, challenging or urgent issues. ${ }^{152}$ This is a typical way of the Communist Party regime to gather resources and coordinate positions among government agencies. The working groups are headed by one government agency, a vice Premier or the Premier, and have the highest policymaking power on the issue in concern. Certainly the ones headed by state leaders have a higher authority over government agencies than those led by a ministry of the same rank, and the ways of policy coordination vary accordingly.

\footnotetext{
${ }^{150}$ Destler, American Trade Politics.

${ }^{151}$ Lampton, ed., The Making of Chinese Foreign and Security Policy. Hamrin and Zhao, eds., DecisionMaking in Deng's China.

${ }^{152}$ Lu, The Dynamics of Foreign-Policy Decisionmaking in China.
} 
Because the capacity of China's foreign economic policymaking bureaucracies is often stretched, available resources gathered on one policy issue through working groups, particularly human resources, are likely to be summoned again to cope with similar issues. But if those personnel and material resources are not preserved through institutionalization, they will be easily lost to other responsibilities and concerns of existing institutions and thus unable to meet similar future challenges. Therefore policymakers sometimes need to identify a policy area as new and crucial, create formal institutions based on previous ad hoc arrangements, in order to stabilise the redistribution of power and resources for managing the recurring new issues. For instance, the Office of Fair Trade was created by MOFCOM as anti-dumping law suits against China at the WTO posed a new challenge to Chinese exports. The Central Working Leading Group for WTO Affairs, created to coordinate China's application to join the WTO, existed for over five years after China's accession and played an important role in the implementation of WTO commitments and in the policymaking of other foreign economic policy issues related to the WTO membership. ${ }^{153}$ The Department of WTO was also created in MOFCOM to meet the need of accession negotiations, and as will be discussed in Chapter Five, because of their experience in complicated international trade negotiations, they have been delegated with the responsibility to negotiate China's first free trade agreements with developed countries, Australia and New Zealand.

\subsubsection{Change of key actors}

Finally, a change in the composition of key actors, or the ruling coalitions, may cause significant institutional change. A change in government, for instance from one that is most concerned with domestic full employment to one that seeks export expansion and overseas investment, is likely to lead to a very different set of mechanisms and rules of foreign economic policymaking. In China, the dominant economic policymaking institution of the command economy in the Mao's era borrowed a lot from that of the Soviet Union, but was changed significantly by the second and third generations of the leadership, who believed in the virtues

\footnotetext{
${ }^{153}$ Yi Zhu, "zhengfu xinjigou zhongbang dengchang [Government New Institutions Big Launch]", Economic Outlook of the Bohai Sea no. 11 (2002). In March 2008, the Leading Group of WTO Affairs was abolished amongst many other central leading groups and its portfolio was transferred to MOFCOM, reflecting the Chinese government's belief that major tasks of implementing WTO commitments had been accomplished.
} 
of a market economy. ${ }^{154}$ As will be discussed in more detail, the shift of the leading position in China's policymaking on China-ASEAN FTA from the Ministry of Foreign Affairs to the Ministry of Commerce caused important changes in the policymaking institution, namely from a highly insulated and strategic-centred system to a more inclusive and economic-centred one.

Institutional changes have played a crucial part in causing significant policy changes. ${ }^{155}$ Rather than a single case of ad-hoc institutional design, a comparison between several policymaking processes on regional economic cooperation may reveal whether there is a trend of institutionalization in one issue area (such as FTA policymaking), and whether China's foreign economic policymaking institutions differ significantly across issue areas (for instance between trade and finance).

In summary, it is suggested here that institutional change happens not only because of fundamental changes in actors' policy preferences, but also through institutional learning, upon the opportunity of the emergence of new policy areas and/or following the change in the composition of the key actors. On top of the major task of the case studies - to study how institutions influence policymaking — the other task is to look for changes in China's foreign economic policymaking institutions, and see if those three proposed sources have effected the changes.

\subsection{Adapting historical institutionalism to study China's foreign economic}

\section{policymaking}

In pre-reform China, ideology and national political interests dominated various aspects of state policies, including foreign economic policy. As China reforms and opens up, however, domestic industrial and local interests become increasingly vocal and powerful in foreign economic policymaking. ${ }^{156}$ Many other actors, including scholars, international organisations

\footnotetext{
${ }^{154}$ Shirk, How China Opened Its Door. Lardy, China's Unfinished Economic Revolution. Harry Harding, China's Second Revolution: Reform after Mao (Washington D.C.: Brookings Institution, 1987). Saich, Governance and Politics of China.

${ }^{155}$ Robert C. Lieberman, "Ideas, Institutions and Political Order: Explaining Political Change", American Political Science Review 96, 4 (December 2002): 697-712. Ikenberry, "Conclusion: An Institutional Approach to American Foreign Economic Policy." March and Olsen, Rediscovering Institutions.

${ }^{156}$ Lampton, "China's Foreign and National Security Policy-Making Process: Is It Changing, and Does It Matter?". Pearson, "The Case of China's Accession to GATT/WTO." Harris, "Globalisation and China's
} 
and foreign actors have also gained influence on China's foreign economic policymaking. On the one hand, the Chinese leadership and central policymakers to some extent rely on domestic actors for political support, information, policy suggestions and policy implementation; therefore the state needs to accommodate some of their interests. If policies hurt the support of important sectors for the central leadership, it would be inconsistent with the national interest by definition according to China's 'democratic-centralization' political system. Besides, noncooperation in implementation by domestic sectors would result in de facto nullification of state policies.

On the other hand, the Chinese leadership and central policymakers are supposed to represent the national interest in foreign economic policymaking; without the need to win regular elections, they still enjoy some autonomy to pursue the national interest as they perceive. Therefore part of the competition among ideas and interests in China's policymaking is for them to become a constituent part of that national interest so they can be expressed by national policies. Foreign economic policy needs to suit both domestic needs and China's international strategies. Economic growth and more recently development are the most important policy objectives that the Communist regime has been pursuing to sustain its legitimacy. ${ }^{157}$ Meanwhile, China's international position has changed and is changing dramatically.

Therefore to study China's present-day foreign economic policymaking, one should take into consideration all the ideas and interests involved in policymaking, and observe how they interact with each other to produce specific policy outcomes. To be sure, they do not interact with each other randomly but within certain institutional constraints. Especially in a country like China that stresses order and conformity, institutions play a major role in structuring the interactions among policy preferences. Historical institutionalism provides such a comprehensive yet systematic approach to studying China's foreign economic policymaking.

Diplomacy". Shirk, How China Opened Its Door. David Zweig, Internationalizing China: Domestic Interests and Global Linkages, Cornel Studies in Political Economy (Ithaca: Cornell University Press, 2002).

157 Shirk, China, Fragile Superpower. John Wong and Wei Liu eds., China's Surging Economy: Adjusting for More Balanced Development (Singapore: World Scientific, 2007). Nicholas Lardy, "China's Domestic Economy: Continued Growth or Collapse?”, in C. Fred Bergsten, Bates Gill, Nicholas R. Lardy and Derek J. Mitchell eds., China, The Balance Sheet: What the World Needs to Know Now About the Emerging Superpower (Washington D.C.: Center for Strategic and International Studies and the Peterson Institute for International Economics, 2006). 
Moreover, because historical institutionalism is a rather neutral conceptual framework for social and political systems, it does not have a biased view drawn from practices in Western developed countries. It advocates that hypotheses be developed inductively in the process of gathering empirical information, and at the same time acknowledges that more specific propositions are needed for purpose of enquiry. ${ }^{158}$ This study proposes that it is worth investigating the features of China's policymaking institutions in the dimensions of insulation, collective action and fragmentation, and analyzing to what extent they affect policy outcomes.

To study the role of institutions in foreign economic policy making in China, one should also keep in mind the changing external and internal environments of Chinese institutions. Institutional change has significant impacts on policy outcomes, and is itself an important subject in China studies. ${ }^{159}$ Tensions abound between the resistance to change of old institutions — as a legacy of the command economy and authoritarian political system, and a side effect of partial reforms - and demand new institutions to accommodate new interests, ideas and policy areas arising from economic liberalization and international cooperation. Because of internationalisation and reforms, the composition of key policymakers often changes, and policymakers sometimes grasp opportunities, such as the emergence of a new policy area and the need to participate in international cooperation, to devise institutional arrangements that are conducive to certain policies.

In short, the role of institutions in structuring interactions among interests and ideas, as well as institutional change out of the constraint of old institutions, is important in the Chinese context of foreign economic policymaking. Important empirical questions remain to be answered about China's foreign economic policymaking and there is little empirical account of China's policymaking on regional economic cooperation.

This study is concerned with how institutions structure the interactions among various interests and ideas to produce specific policy outcomes, and how institutions are developed in this process. The interactions among interests and ideas include how they constitute, prevail or

\footnotetext{
${ }^{158}$ Steinmo et al., Structuring Politics: Historical Institutionalism in Comparative Analysis.

${ }^{159}$ Shaun Breslin, "Reforming China's Embedded Socialist Compromise: China and the WTO," Global Change, Peace and Security 15, no. 3 (October 2003). Reardon, The Reluctant Dragon. Kjeld Erik Brødsgaard and Zheng Yongnian eds., The Chinese Communist Party in Reform (Hong Kong: Hong Kong Chinese University Press, 2007).
} 
transform each other. The following empirical chapters will provide an analytical description of China's policymaking of regional economic cooperation through in-depth case studies, namely the China-ASEAN Free Trade Agreement, the proposed Australia-China Free Trade Agreement and East Asian Financial Cooperation. Following the conceptual framework, there are three general issues for investigation in each case:

First, what interests or ideas motivated political actors to participate in foreign economic policymaking? In particular, what were the specific interests or ideas coming from four sources: the actors' position in the economy (for instance, as indicated by the specific factor model); the actor's position in the domestic politics; the belief of the national interest in China's regional/international status; and, the concern over domestic economic performance.

Second, how did various interests and ideas interact with each other? How significant was the impact of institutional settings on the policy outcomes, particularly by affecting the power and preferences of actors? Importantly, why have some interests or ideas triumphed over others and led to China's regional economic cooperation policies?

Third, how were institutions created and transformed in the process of policymaking? What was conducive to institutional changes? 


\section{Chapter 3 Preferences in the China-ASEAN Free Trade Agreement}

Southeast Asia is the earliest and arguably the most important target of China's regional economic diplomacy. At the Fourth ASEAN-China (also called ' $10+1$ ') Summit in Singapore in November 2000, then Chinese Premier Zhu Rongji proposed that a free trade relationship be established between China and ASEAN, the first of this kind in China's history of economic diplomacy. Swift actions were then taken on both sides, in particular by the Chinese policymakers, to realize this initiative. A year later, based on the report submitted by the ChinaASEAN Experts Group on Economic Cooperation, at the Fifth ASEAN-China Summit on 6 November 2001 in Bandar Seri Begawan, Brunei, the leaders of the eleven countries decided to establish a China-ASEAN Free Trade Area (CAFTA). ${ }^{1}$ At the next Summit in Phnom Penh, Cambodia, on 4 November 2002, the leaders signed the Framework Agreement on the Comprehensive Economic Cooperation between ASEAN and China, which came into force on 1 July 2003. Following a provision in the Framework Agreement, the leaders agreed on a Protocol for an Early Harvest Program (EHP) - a fast-track trade liberalization of agricultural products. A Sino-Thai FTA on trade in vegetables and fruits, as part of the EHP was signed in 2003 and came into effect earlier than for other ASEAN countries on 1 October 2003. In November 2004, in Vientiane, Laos, the Agreement on Trade in Goods, which was to come into force on 20 July 2005, and the Agreement on Dispute Settlement Mechanism were concluded between ASEAN and China. The Agreement on Trade in Services was signed at the $10^{\text {th }}$ ASEAN-China Summit in Cebu, the Philippines, in January 2007, which was to enter into force in July. The Agreement on Investment is currently under negotiation.

Surprised by China's unprecedented initiative and the swiftness of the subsequent materialization of the CAFTA, observers have asked many questions regarding China's foreign economic policy and domestic policymaking. For example, has China forgone multilateralism once it ascertained WTO membership and adopted bilateralism and regionalism instead as the major means of international economic cooperation? Does the CAFTA signal China's enhanced

\footnotetext{
${ }^{1}$ It is also referred to as ACFTA. I will use CAFTA in this thesis, as most Chinese media do, to denote that it was proposed by China, and to distinguish from the Australia-China FTA (AUCFTA).
} 
commitment to integration processes in East Asia and in Asia Pacific? Has China's style of economic diplomacy changed from being informal to legalist, from passive to proactive? Moreover, how does China choose among competing ideas and interests, for instance between state political and economic interests, between international economic interests and domestic sectoral interests, and between protection and liberalization as the dominant approach to industrialization?

This chapter will introduce the various preferences that influenced China's policy on the CAFTA, including the national and domestic interests that were at stake when the CAFTA was contemplated, who represented these domestic interests, and the ideas held by the policy elites - central government officials and scholars who participated in the policymaking of the CAFTA - regarding the formation and the form of the CAFTA. Many of the interests and ideas in China concerning the CAFTA also exist in China's other FTA plans. This discussion serves as the background and foundation of the next chapter, which will depict China's policymaking process on the CAFTA, and highlight the role of the institutions that structured the interactions of those preferences and determined which ones prevailed during the policymaking process.

\section{National Interests}

As argued before, policymaking is itself a process of defining what constitutes the national interest, a competition among political actors in trying to persuade policymakers that their interests or ideas represent or are part of the national interest. The definition also depends heavily on the policymakers' ideas about what the national interests are in the particular case. Therefore the next chapter discusses in greater depth how Chinese policymakers made choices and formed their views on national interests. It is worth knowing first the national political and economic interests that the Chinese state held in the CAFTA, as explicitly expressed in its official statements, and confirmed by the author's interviews with Chinese officials and experts who participated in the policymaking. It can be said that the Chinese policymakers' aims from the CAFTA were quite functional - not for global or domestic economic liberalization, but to achieve practical political and economic interests of the state. 


\subsection{Political Interests}

It is widely acknowledged among Chinese officials and scholars that the motivation of China in proposing an FTA to ASEAN was more political than economic. First of all, China wanted to allay ASEAN's worries of China's economic threat upon its accession into the WTO. ${ }^{2}$ In this sense, it is a typical case of "economic statecraft" ${ }^{3}$ - China used economic policy as an instrument to achieve foreign policy goals. In fact, the Chinese foreign relations policy circle had long been looking for an effective way to engage its Southeast Asian neighbours since the early 1990s but had so far felt that it lacked effective instruments. Doubt and fear remained ostensible among ASEAN countries against the rising giant next to them. Besides, Japan was leading the process of economic regionalisation through extensive foreign direct investments. Therefore, the CAFTA was intended to show that China chose to provide ASEAN countries with special opportunities during China's economic rise. Chinese policymakers claimed that China's economic rise was inevitable and it was not China's intention to compete with ASEAN, but the CAFTA had the capacity to coordinate resources and increase the global competitiveness of both economies. ${ }^{4}$ Therefore China intentionally championed ASEAN countries by opening its domestic market to them earlier than to others, given that the Chinese trade policymakers had realized that many countries were vying for that market upon China's accession into the WTO. Chinese scholars held that the political motivation was also demonstrated by Beijing's signing strategic agreements around that time to allay ASEAN's worries of a security threat from the north. As part of China's 'mulin youhao' [peaceful and friendly neighbourhood] policy, Chinese policymakers believed the CAFTA would stabilise

\footnotetext{
${ }^{2}$ Interviews with many scholars and officials in Beijing February-June 2006. Also see Yunling Zhang and Xiaobing Zhou, eds., Dongya Hezuo De Jincheng Yu Qianjing [the Progress and Prospect of East Asian Cooperation] (Beijing: World Affairs Press, 2003), 14. Kwei-Bo Huang, "The China-ASEAN Free Trade Area: Background, Framework and Political Implications," in Peace Forum (Taiwan Research Institute: 2002). Lijun Sheng, "China-ASEAN Free Trade Area: Origins, Developments and Strategic Motivations," ISEAS Working Paper: International Politics and Security Issues Series, no. 1 (2003). Daojiong Zha, "The Politics of China-ASEAN Economic Relations: Assessing the Move toward a Free Trade Area," Asian Perspective 26, no. 4 (2002). Elena Ianchovichina, Sethaput Suthiwart-Narueput, and Min Zhao, "Regional Impact of China's WTO Accession," in East Asia Integrates: A Trade Policy Agenda for Shared Growth, ed. Kathie L. Krumm and Homi J. Kharas (Washington, D.C: World Bank, 2004). ${ }^{3}$ David A. Baldwin, Economic Statecraft (Princeton, N.J.: Princeton University Press, 1985).

${ }^{4}$ Interview with an economist in Beijing on 1 March 2006. Also see Changwen Xu, Guanghui Li, and Wei Li, Zhongguo Lingpao Dongya Jingji Hezuo [China Leading the Race of East Asian Economic Cooperation] (Beijing: China Customs Press, 2003), 158; Zhang and Zhou, eds., East Asian Cooperation. Qiaozhi Chen, ed., Dongya Quyu Jingji Hezuo Yanjiu [Studies of East Asian Regional Economic Cooperation] (Beijing: China Social Sciences Press, 2002).
} 
China's political and economic relations with neighbouring countries, therefore it had significant utilities in ensuring its national security. ${ }^{5}$

The CAFTA initiative was also a landmark in China's diplomacy in taking the leading position in propelling the progress of East Asian cooperation by forging institutional arrangements and making economic concessions first. It is not certain whether the proposal was intended as a diplomatic coup by China against Japan, which had been seeking economic cooperation partnership with ASEAN. However, China has since reiterated that it made important contributions to East Asian cooperation because Japan and Korea followed by proposing similar arrangements to ASEAN.

Some Chinese scholars believe the CAFTA and other East Asian arrangements it stimulated would help curb the ambition of the US to dominate Asia. ${ }^{6}$ It is not clear either whether that was part of the motivation but the CAFTA has been listed as a step towards integration in East Asia rather than in the Asia Pacific. ${ }^{7}$ Chinese policy elites have pointed out that the CAFTA would raise the voice of East Asian countries as a group in global trade and economic issues. ${ }^{8}$ Later, Beijing learned that the CAFTA did indeed have the potential to increase China's influence on ASEAN when Malaysia, backed by China, took a strong position, at least initially, to exclude the US and Australia from the East Asian Summit.

Whether or not China hoped to marginalize Taiwan from regional affairs is part of the question whether China could increase influence on ASEAN's diplomacy. When the Singaporean Deputy Prime Minister Lee Hsien Loong visited Taiwan in July 2004, China shelved Singapore's proposal to consider a bilateral FTA in services trade and investment ahead of other ASEAN countries. From the experience of the CAFTA, as will be discussed later, Beijing learned that FTAs are a forceful tool to achieve foreign policy goals, and the form of

\footnotetext{
${ }^{5}$ Interview with a trade official in Beijing on 23 March 2006. Xiangyang Chen, Zhongguo Mu Lin Waijiao: Sixiang, Shijian, Qianzhan [China's Good-Neighbour Diplomacy: Thought, Practice and Prospect] (Beijing: Current Affairs Press, 2004). Xu, Li, and Li, China Leading the Race, 144. Zhang and Zhou, eds., East Asian Cooperation, 130. Yunling Zhang and Jianglin Zhao, eds., Yatai Quyu Hezuo De Fazhan [Developments of Asia Pacific Cooperation] (Beijing: World Affairs Press, 2003), 13-16. ${ }^{6}$ Huang, "The China-ASEAN Free Trade Area." Sheng, "China-ASEAN Free Trade Area." Zha, "The Politics of China-ASEAN Economic Relations."

${ }^{7}$ Zhang and Zhou, eds., East Asian Cooperation, 10-11. Yunling Zhang, ed., Shijie Quyuhua De Fazhan Yu Moshi [the Development and Models of Regionalization in the World] (Beijing: World Affairs Press, 2004), 204-06.

${ }^{8} \mathrm{Xu}, \mathrm{Li}$, and Li, China Leading the Race, 157-58.
} 
cooperation should be substantial so that the other party will increase economic dependency on China - or be "bound with China", in the words of Chinese trade policymakers. ${ }^{9}$ Moreover, because the CAFTA caused other countries to be eager to enter FTAs with China, Chinese policymakers feel that championing one helps increase China's privilege in FTA negotiations with others.

\subsection{Economic Interests}

Before analyzing the economic interests of domestic actors in China, what are China's economic interests in the CAFTA at the national level? Was it regarded as an important opportunity for China to increase exports, which is the usual justification stated for most FTAs? Was it intended to increase the import of certain kinds of goods from ASEAN? Was the CAFTA an excuse that the central government intended to use for imposing domestic economic liberalization, like the WTO?

First, China hoped to utilize the economic 'complementarity' with the ASEAN economies for 'mutual benefits', to use the words of the Framework Agreement, which implied improved access to each other's markets. First, Beijing wished to guarantee ASEAN's supply of energy and raw materials to China, in part through obtaining better environments for Chinese investment there. Second, Chinese trade policymakers did not think the size of the ASEAN market was substantial, but they thought it necessary to seek every market opportunity for Chinese exports. The CAFTA would help achieve the objective of developing multiple export markets because Chinese trade policymakers were worried of the (over)dependence of Chinese exports on a few markets in developed countries like the US and Japan. Whether the CAFTA would serve this purpose or exacerbate the problem, however, is a question to be discussed later.

${ }^{10}$ Moreover, Chinese trade officials thought that the CAFTA would be useful to deal with trade protectionism in American and European regional integration, and help to reduce the dependence of both parties on those markets. ${ }^{11}$

\footnotetext{
${ }^{9}$ Interview with a MOFCOM official, Beijing, 23 March 2006.

${ }^{10} \mathrm{Xu}, \mathrm{Li}$, and Li, China Leading the Race, 155.

${ }^{11}$ Ibid., 144. Zhang, ed., Regionalization in the World, 14; Zhang and Zhao, eds., Asia Pacific Cooperation.
} 
Although some ASEAN countries were concerned with China's competitive exports, they signed the agreement with the expectation of more benefits (such as gaining access to the Chinese market and attracting more Chinese investment) than adjustment costs associated with trade liberalization (only for some to realise later that perhaps the costs would be more painful). Chinese policymakers were also aware of the potential impact on some Chinese producers particularly farmers of tropical produce, as will be discussed in more detail, but political considerations outweighed economic costs, and state interests overwrote local concerns.

It is said that some Chinese economists pointed out that the CAFTA - or FTAs in general - would reduce the tariff revenue from imports. However, trade officials thought that the amount of Sino-ASEAN trade was not substantial in China's total trade, and that tariff reduction was expected anyway because of the WTO commitments, and therefore the CAFTA would not bring much difference to China. Enhanced access to ASEAN markets, in particular for manufactured goods, was expected to bring more profits than the reduction of tariff revenue. $^{12}$

Second, China hoped the CAFTA would boost the exports of its Southwest provinces which border ASEAN countries. These provinces are not as developed as coastal ones because of geographical conditions as well as Beijing's preferential policies for the coastal area centred on 'special economic zones'. However, 'the Great Development of the West' has become an important national policy since the late 1990s in view of serious regional inequality. Because ASEAN countries had been the main market for Southwest provinces in China, Beijing hoped the CAFTA would bring significant economic benefits to these provinces.

Third, Chinese policymakers view FTAs as an important policy option for a country to create more space for economic development. The enlargement of market size and the establishment of market coordination mechanisms in China and ASEAN would improve the investment environment and attract more investments from outside the region. It is another area of potential that China hoped to realize.

Fourth, China requested Market Economy Status from its FTA partners, as a step towards being recognized world wide so that it would not be in a disadvantaged position in anti-dumping

${ }^{12}$ Interviews, Beijing, March to May 2006. 
suits in the WTO. China learned that it could request Market Economy Status from the preparations for negotiations with Australia, and made a similar demand to ASEAN. It obtained MES from ASEAN in September 2004 and included it in the Agreement on Trade in Goods signed in November that year.

In sum, if the WTO has been used by the Chinese central government to impose domestic sectoral liberalization, ${ }^{13}$ the functions of FTAs for Beijing are narrower and more practical - to expand exports, to secure the supply of raw materials and to obtain the Market Economy Status. Some degree of enhancement in China's economic efficiency was expected from FTAs since they were part of China's 'open-door' foreign economic policy, which had had that effect on the domestic economy for the past two decades. However, no evidence has shown that domestic reform was a major objective of the Chinese state in pursuing FTAs.

\section{Domestic Interests}

What are the stakes of Chinese domestic actors in the CAFTA? Who are the winners and losers? This section will analyze Chinese domestic interests in the FTA as a background to the story of how they participated in the policymaking process in the next chapter, especially to discover actors that one might have expected to have been involved but were not. Domestic economic interests include export-oriented and import-competing industries, owners of capital and labour, and local governments. Apart from economic interests, career or development goals of government officials, academics and business associations potentially are also important factors. Because the career goals of businesspeople are usually consistent with the business interests of their firms or locality, the following discussion on the portfolio and interests of agencies will be focused on those of the state.

\footnotetext{
${ }^{13}$ Margaret M. Pearson, "The Case of China's Accession to GATT/WTO," in The Making of Chinese Foreign and Security Policy in the Era of Reform, 1978-2000, ed. David M. Lampton (Stanford: Stanford University Press, 2001). Joseph Fewsmith, "China and the WTO: Politics Behind the Agreement," NBR Analysis 10, no. 5 (December 1999). Nicholas R. Lardy, Integrating China into the Global Economy (Washington, D.C.: Brookings Institution Press, 2002), 9-22. Shaun Breslin, "Reforming China's Embedded Socialist Compromise: China and the WTO," Global Change, Peace and Security 15, no. 3 (October 2003).
} 


\subsection{State agencies}

There has been a general division of labour between MFA and MOFTEC/MOFCOM in China's policymaking of regional economic cooperation. The MFA designs grand strategies and reviews specific policy proposals based heavily on strategic considerations, which will be reported to the leadership. If the strategies or proposals are approved, MOFCOM will research how to operationalize them. For MOFCOM, the two important policy objectives are to expand China's international economic relations, and to promote domestic economic liberalisation. Sometimes, not only MOFCOM but also the central bank (the People's Bank of China) or the Ministry of Finance (MOF) may participate in the operationalization because they are in charge of financial issues and the State Tariff and Taxation Committee resides within MOF. As agencies in charge of China's financial policies, the central bank and MOF are most concerned with China's financial stability. MOF may be concerned with the tariff revenue of China, but it also calculates the total balance sheet including taxes from export companies. In fact, it usually serves only as a functional institution in China's FTA policymaking, providing technical support rather than making policies. ${ }^{14}$

As to specific problems in an FTA, MOFCOM will seek the opinions of relevant groups, for instance, on agricultural issues from the Ministry of Agriculture, and on some main industries from corresponding national business/industrial associations. These national business associations' former bodies were the industrial ministries, which were downgraded by Zhu in 1998 to weaken their hold on the command economy. Now these industrial business associations are officially affiliated with MOFCOM, but the relationship between MOFCOM and associations is 'instruction' rather than 'administration'. They still maintain influential representation at the State Council. Other societal and sub-national business associations have far less access to China's foreign economic policymaking, hence little influence. ${ }^{15}$

Because FTAs have an impact on domestic industries, the National Development and Reform Commission (NDRC) is involved in policymaking since all of the domestic economic

\footnotetext{
${ }^{14}$ Interviews with a MOF official in Beijing on 21 March 2006 and a scholar on 14 April.

${ }^{15}$ Interviews with MOFCOM officials in Beijing on 16, 23 March 2006. Also see Bin Sheng, Zhongguo Duiwai Maoyi Zhengce De Zhengzhi Jingji Fenxi [the Political Economy of China's Foreign Trade Policies] (Shanghai: Shanghai Sanlian, 2002).
} 
issues are in its portfolio. It was the former State Planning Commission, the core institution of the previous command economy. Its power of control over domestic industries and influence on foreign economic policies was reduced in the 1998 government restructuring which was aimed at marketization, though it experienced a resurgence under the Hu-Wen leadership.

\subsection{Industries}

The high tariffs of both China and ASEAN were regarded as one of the major barriers to bilateral trade by Chinese policymakers. ${ }^{16}$ Non-tariff barriers were a significant obstacle to bilateral trade as well. For instance, ASEAN had high tariffs in motorcycles, alcoholic drinks, some grains, cattle and meat, sugar and some vegetables, as well as quotas for automobiles and their parts, rice, coal etc. In order to reduce those barriers, China had to make concessions by offering lower tariffs than its MFN rate under the WTO. In general, the price of some products in China's domestic market was expected to fall because of increased ASEAN imports, which would be good for consumers, but not good for the investors or workers in those sectors. On the other hand, Chinese manufacturing industries would mostly benefit if ASEAN reduced tariffs on manufactured goods, and those engaged in intra-industry trade may benefit from better conditions for investing in ASEAN.

\section{Agriculture}

Agriculture was China's main sector most likely to be affected by the CAFTA. Because of its limited cultivatable land and natural resources, over all China is not internationally competitive in land-intensive agricultural products such as sugar and rice. Because of better natural endowments, ASEAN tropical products have better quality and more harvests in a year. Moreover, much of ASEAN agriculture has bigger scale of production than Chinese. After the commune system was replaced by the 'family contract' [bao gan dao hu] system in the late 1970s, Chinese agricultural production has mostly been organized on a small scale — in the unit of families. For a combination of factors in natural endowments and the organization of production, many ASEAN tropical products are cheaper than Chinese ones. Vietnam, Thailand

\footnotetext{
${ }^{16} \mathrm{Xu}, \mathrm{Li}$, and Li, China Leading the Race, 85.
} 
and other ASEAN countries are traditional agricultural exporting countries. Vietnam's rice, coffee, vegetables and tea, and Thailand's rice are internationally competitive. The Institute of Foreign Trade and Economic Cooperation (IFTEC, a research institute affiliated with MOFTEC) predicted that the enforcement of the CAFTA would certainly impact on China's agricultural production. ${ }^{17}$

Some Chinese agricultural economists argued that the expected increases of imports under the CAFTA would not cause major problems for Chinese agriculture. ${ }^{18}$ According to them, China was basically self-sufficient in rice, and therefore there would not be much demand or market space for imports. Moreover, Thai rice was more expensive than Chinese local rice, not to mention transportation costs, and therefore it catered only to a small group of consumers and had only $1 \%$ of the market share in China. Because the domestic market of grains (rice, wheat, etc.) had been liberated in China - not segmented by provinces - and they are easy to preserve, their price was almost the same across the country. ${ }^{19}$ The adverse impacts of imported rice would not fall on only a few provinces but would be ameliorated by the size of the national market. Sugar was more worrying to the Ministry of Agriculture because the domestic sugar market was still segmented and therefore the impact of imports was likely to be concentrated on a few sugar-producing provinces ${ }^{20}$ Besides, small-scale palm and rubber plantations owned by farmers in Southern China, mostly in Hainan Province, might be affected by ASEAN imports. However, MOFTEC (or MOFCOM from 2003) was confident that the increase of imported sugar, grains or oils would not be significant because state companies had an administrative monopoly over the foreign trade of those products; through it the government could control the amount of imports, even below the official quota. ${ }^{21}$

China does have comparative advantage over ASEAN in some temperate products such as onions, garlic, potatoes, apples, oranges, mandarins and grapefruits. ${ }^{22}$ The Philippines did not participate in the EHP initially because of objections from domestic producers of temperate

\footnotetext{
${ }^{17}$ Ibid., 192.

${ }^{18}$ Interview with two agricultural economists in Beijing on 29 March, and on 5 April.

${ }^{19}$ Chenggui Li, "Zhongguo Dami Zhengee Fenxi [an Analysis of Rice Policy in China]," China Agricultural Economics, no. 9 (2002).

${ }^{20}$ Interview with a MOA official on 25 March 2006.

${ }^{21}$ Interview with a MOFCOM official in Beijing on 23 March 2006.

${ }^{22}$ Zhongqun Liu, Shuquan Huang, and Lin Wang, "A Research Summary on the Structure of China's Agricultural Exports to ASEAN," Around Southeast Asia, no. 4 (2006).
} 
fruits and vegetables. Instead of pursuing its comparative advantage, however, China allowed the Philippines and less developed ASEAN countries (Cambodia, Laos, and Vietnam) to exclude many such items as sensitive products from tariff reduction in the Early Harvest Program.

Various actors are involved in China's agricultural trade, mainly: the Ministry of Agriculture, which is in charge of this industry in China; MOFTEC/MOFCOM, concerning trade; the General Administration of Quality Supervision, Inspection and Quarantine concerning those technical issues of trade; some state import and export companies, which have a monopoly over agricultural trade; local governments of provinces that rely heavily on agriculture; state-owned and private food processing companies; business associations of agricultural producers; and last but not the least, farmers.

China has had increasing trade deficits with ASEAN in agricultural trade since the introduction of the Early Harvest Program (including the Fruit and Vegetable Agreement with Thailand), in which China reduced or eliminated tariffs on most agricultural goods from ASEAN ${ }^{23}$ Considering agriculture is traditionally a sensitive sector in WTO negotiations and FTAs of most other countries, why could Chinese trade negotiators give concessions in the CAFTA? After all, agriculture had always been the foundation of the national economy of China. Did the Chinese agricultural sector express their concerns to the trade ministry or the State Council? Why was the Chinese agricultural sector unable to prevent the government from 'sacrificing' it? The next chapter will reveal that the answer is not as simple as that China is an authoritarian state.

\section{Resources}

Securing access to ASEAN's abundant natural resources as energy and industrial inputs was one of the main objectives of the Chinese government in the CAFTA. The stable supply of energy and resources has been regarded by Chinese policymakers as an aspect of China's economic and strategic security. Resource products have been a major category of China's imports from ASEAN since the early 1990s. ASEAN had comparative advantage in mineral

${ }^{23}$ Hong Li, "Analysis and Prediction on Sino-ASEAN Trade 2005-2006," Around Southeast Asia, no. 3 (2006). 
products (including mineral fuels), plastic and rubber products, wood and wooden products, paper pulp and paper products, and oils. Therefore Indonesia, Malaysia and Thailand requested China to add a list of 'specific products' to the Early Harvest Program for fast-track mutual tariff reduction, including palm oil, soap, anthracite and coke. The production and trade of mineral and petrol products in China were monopolized by state-owned enterprises such as SinoPec (the China Petroleum and Chemical Corp.), the China National Overseas Oil Corp. (CNOOC), or the national business associations under the MOFCOM, such as the China Chamber of Commerce of Metals, Minerals and Chemicals, the China Iron and Steel Association, and the China Non-Ferrous Industry Association. Among them, domestic upstream raw material producers might suffer from import competition, while processing and trading companies would gain from easier access to and cheaper prices of raw materials. For example, SinoPec with oil wells in Indonesia, for example, would prefer the tariff to be reduced or be given preferential treatments by the ASEAN governments to facilitate exploration. However, as MOFCOM officials believed, the demand for energy and resources were so high in both domestic and international markets that it was doubtful whether increases in imports from ASEAN would have a significant impact on domestic upstream producers.

Business associations in other countries are usually representatives of the industries' interests and play the role of lobbying in national policymaking, but the nature and role of Chinese business associations are quite different. As will be discussed in the next chapter, the degree of the autonomy of Chinese business associations vis-à-vis the state varies, and many of them were founded from former government agencies. Therefore it is questionable whether these associations would identify their interest with the state or with the domestic actors, and how significant a role they can play in China's foreign economic policymaking. ${ }^{24}$

Because China's industrialization and rising level of consumption demand resources, the tariffs of most mineral products had already been reduced or eliminated. The CAFTA was the start of China's global hunt for energy and resources through FTAs. The Chinese government encourages companies to invest in energy and resources exploration projects in ASEAN by

${ }^{24}$ Also see Scott Kennedy, The Business of Lobbying in China (Cambridge, Mass.: Harvard University Press, 2005). 
offering financial incentives (such as low-interest rate loans), granting priority in overseasinvestment licensing, organizing business trips to ASEAN, and providing policy guidance about the investment environment in ASEAN countries. New areas for exploration include hydroelectricity and natural gas from countries bordering China so that they can be transmitted to the adjacent provinces of China.

\section{Manufacturing}

The picture of Sino-ASEAN trade in manufactured goods was complicated. Generally, China and ASEAN economies (except Singapore) had similar levels of development, but China had comparative advantage over ASEAN in labour-intensive products. Excess capacity had been reported in many Chinese domestic manufacturing industries, especially electronic appliances and some other labour-intensive products. Meanwhile, Chinese labour-intensive products had recently been facing increasing barriers in the US and Europe. Because exports had been a major source of China's GDP growth and companies' revenue, China was turning to developing countries for new markets. MOFTEC was interested in the ASEAN markets because Chinese manufactured goods were suitable for the consumption level there. Motorcycles, home electronic appliances, and apparel made in China had been selling well in Indo-China.

Although the labour costs in some border regions of China had already surpassed those of the neighbouring countries such as Laos, Myanmar, and Cambodia, MOFTEC did not think these countries had a significant manufacturing sector or the technology for production. The IFTEC warned, however, that the subsidiaries of industrialized country multinational corporations located in ASEAN would utilize the resources and preferential policies in both China and ASEAN and might put Chinese companies at a disadvantage. Besides, the technological level of Chinese companies was still behind that in the newly industrialized countries, and their management and services were even further behind. ${ }^{25}$ However, a Chinese trade official pointed out that the development of many industries in ASEAN such as the automobile industry of Malaysia was under high tariff protection. ${ }^{26}$ Overall, MOFTEC believed

\footnotetext{
${ }^{25} \mathrm{Xu}, \mathrm{Li}$, and Li, China Leading the Race, 276.

${ }^{26}$ Interview with a MOFCOM official, Beijing, 23 March 2006.
} 
China would stand to win in manufacturing in the trade with ASEAN under the CAFTA but it was not sure how much market potential could be explored.

However, because ASEAN was worried about the competition of Chinese manufactured goods upon China's accession to the WTO, ${ }^{27}$ for the original purpose of the CAFTA - to befriend and benefit ASEAN — China did not include the manufacturing sector in the Early Harvest Program. ${ }^{28}$ Later China allowed ASEAN to have many sensitive products exempted or delayed in tariff reduction in the Agreement on Trade in Goods, including rubber products, plastic products, ceramic products, some textiles and apparels, steel, some home electronic appliances, automobiles and motorcycles. Given MOFTEC's interest in the ASEAN markets, why did Chinese trade negotiators from MOFTEC make such a concession in the agreement? Did the manufacturing sectors express their objection to being excluded from the EHP? Or did Chinese manufacturers not succeed in lobbying the Chinese government to include them in the EHP? Did the Chinese government simply let go of the potential benefits? First, one needs to know which actors might have been involved in China's CAFTA policymaking process with regard to trade in manufacturing goods.

The manufacturing sectors in China were the responsibility of scattered government and quasi-government institutions: the MOFCOM, the State Council's State Owned Assets Supervision \& Administration Commission (or the State Assets Commission), their local branches in the local governments, the National Development and Reforms Committee, and major national business associations which were former industrial ministries. These government agencies had different inclinations between liberalization and the promotion of domestic industrial development. The second and third generations of leadership (led by Deng Xiaoping, and Jiang Zemin and Zhu Rongii) tried to reduce the planning element in the economy in order to construct a market economy, as a major objective of reform and opening and as an obligation to fulfil before entering the WTO. As a result, state intervention in the management of the manufacturing sector had been reduced to a great extent. The state retained ownership, through

\footnotetext{
${ }^{27}$ See Elena Ianchovichina and Terrie Louise Walmsley, "The Impact of China's WTO Accession on East Asia," World Bank Poverty Reduction and Economic Management Network Economic Policy Division (Washington, D.C.), Policy Research Working Paper, no. 3109 (August 2003).

${ }^{28}$ Guoji Shang, China-ASEAN FTA's Experiment Field: The Early Harvest Program (2005 [cited 12 Jan. 2007); available from gjs.mofcom.gov.cn/accessory/200509/1127371793253.doc.
} 
the State Assets Commission, of the 169 enterprises viewed as 'strategic'. Big state-owned enterprises were widely believed to be influential in China's politics. ${ }^{29}$ Foreign trade used to be conducted only through a limited number of import-and-export companies, while now companies could obtain the foreign trade licences directly. The confidence of both manufacturers and the government about China's competitiveness in manufacturing had increased over the years. To what extent these actors participated in the policymaking on CAFTA, and why some of their interests were compromised, will be the main questions that the next chapter will explore.

\section{Intra-industry trade}

Export competition between China and ASEAN used to be concentrated in labourintensive products such as fibres and textiles. With the development of China's technology, the competition has expanded to the traditional advantageous areas of some ASEAN countries, such as electronic products. In 1999, the structure of China's imports from ASEAN changed from mainly resources to manufactured goods. Both sides have imported and exported computer/machinery and electronics products from each other. However, Chinese scholars and policymakers believe it does not mean the competition is directly against each other or impossible to be coordinated. ${ }^{30}$ In the past 10 years, the strongest growth of trade between China and ASEAN has been in manufactured goods, in particular computer/machinery and electronic appliances. This showed the importance of intra-industry trade in bilateral economic relations, coming from segmented production and companies seeking economies of scale. Looking into the subcategories, China mainly exports general machinery and electronics, and imports electronic parts and special instruments. ${ }^{31}$

As argued in the previous chapter, analysis of comparative advantage cannot give a complete picture of bilateral trade relations and the domestic stakes in an FTA, in particular because of the role of intra-industry trade and production networks. Intra-industry trade has

\footnotetext{
${ }^{29}$ Interviews with scholars at CICIR and Beijing University on 2 and 29 March 2006, and with a trade official on 5 April in Beijing, 2006.

${ }^{30}$ Interviews with scholars in Beijing at CASS and Beijing University on 1, 9, 17 March 2006, and with MOFCOM officials on 23 March, 15 May 2006, and the Director of a National Business Association on 25 April 2006.

${ }^{31}$ For details, see John Ravenhill, "Is China an Economic Threat to Southeast Asia?," Asian Survey 46, no. 5 (Sep./Oct. 2006). Also see Xu, Li, and Li, China Leading the Race, 79.
} 
developed between China and ASEAN, mostly in machinery and electronics, chemical products, optical instruments, accurate instruments and musical instruments. ${ }^{32}$ The technology level of most Chinese companies is lower than that of more developed ASEAN countries (Singapore and Malaysia), but higher than most ASEAN countries. Therefore, Chinese officials hoped that some Chinese enterprises, especially those big- and medium-sized ones, would transfer the production of saturated or mature industries from China to ASEAN, through enhanced conditions under the CAFTA for investment, and utilize local natural resources and cheaper labour. It would help to solve the problem of decreasing profits of domestic industries due to excess capacity, and create market space for China to adjust the industrial structure- to move to a higher level of technology. ${ }^{33}$ Of course, that requires the Chinese workers to enhance their skills or otherwise they would lose their jobs. Moreover, Chinese officials envisaged that Chinese companies investing in an ASEAN country would be able to find new export markets in ASEAN with a low tariff under AFTA. Finally, exporting from ASEAN would help Chinese companies there avoid the high barriers imposed by developed countries against Chinese products, utilizing special treatments enjoyed by the least developed countries (LDCs) such as Cambodia. ${ }^{34}$ Chinese policymakers hoped that the CAFTA would facilitate the development of Sino-ASEAN intra-industry trade and hence China's increased influence in the region, although a 'side effect' of this was likely to be China's increased dependence on markets in developed countries. ${ }^{35}$

In summary, among Chinese domestic industries, Chinese agriculture was expected to lose from the CAFTA while manufacturing to win. The Early Harvest Program and the Agreement on Trade in Goods of CAFTA, however, opened the Chinese agriculture market to ASEAN and allowed ASEAN to keep tariffs on many manufacturing products. The next chapter will discuss why the agreements have taken the form as they did, in particular what factors in China's policymaking institutions led to such results.

\footnotetext{
${ }^{32}$ Zhang and Zhou, eds., East Asian Cooperation, 112.

${ }^{33}$ Interviews with scholars at Renmin University, CICIR and CASS on 23 February, 2, 9 March 2006, with MOFCOM officials on 23 March, 15 May 2006 in Beijing.

${ }^{34} \mathrm{Xu}, \mathrm{Li}$, and Li, China Leading the Race, 274-76.

${ }^{35}$ Interviews with scholars at CASS, Beijing University and MOFCOM officials on 1, 9, 29 March, 5 April 2006 in Beijing.
} 


\subsection{Provinces}

As analyzed above, agriculture was expected to be the main Chinese industrial sector to be adversely affected by the CAFTA, especially from the import of tropical produce and some raw materials. Their cultivation in China is mostly located in Guangxi and Yunnan provinces, and some in Hainan. Because of their geographical proximity to ASEAN, Yunnan and Guangxi grow similar agricultural products, but the natural resources are not as good as in Southeast Asia; nor was the production as organized or industrialized. Because they are mainly agricultural provinces, they were likely to suffer from the impacts of the CAFTA.$^{36}$ In contrast, Guangdong and Fujian mainly have manufacturing industries, and have attracted investments from Southeast Asian Chinese, whose ancestors were mostly from these provinces; therefore they were likely to benefit from increased trade and investments under the CAFTA. There was a huge gap in the level of economic development between Yunnan and Guangxi on the one hand, and Guangdong and Fujian on the other ${ }^{37}$ mainly because of the choice of the government in the 1980 s to develop special economic zones in the latter two.

Since the 1990s China set up border trade areas to facilitate small-volume trade between Guangxi, Yunnan and their respective bordering countries, supported with preferential policies such as tax returns, and special quota. Small amounts of manufactured goods produced by small- and medium-sized enterprises were sold to ASEAN through this channel. The trade volume between China and ASEAN was small in China's total trade, but significant for the provinces. Therefore the local governments were worried that they would lose the advantage over other provinces when the CAFTA came into force. At the same time, they hoped better market access would provide more opportunities for them to develop manufacturing and services industries. Moreover, the successful paths of the Special Economic Zones taught them that being a window of China's economic liberalization would usually accelerate economic

\footnotetext{
${ }^{36}$ Mingxu Wan, "Guangxi's "Access to ASEAN": Problems and Solutions," Around Southeast Asia, no. 2 (2006). Shilu Wang, ed., 2005-2006 Dongnan Ya Baogao [Southeast Asia Report 2005-2006], Yunnan Blue Books (Kunming: Yunnan University Press, 2006).

${ }^{37}$ In 1999 when the CAFTA was first mentioned, the GDP of Yunnan, Guangxi, Guangdong and Fujian were respectively $185.6,195.3,846.4$ and 355.0 billion yuan, and their per capita GDP were respectively 4452, 4148, 11728 and 10907 yuan (source: National Bureau of Statistics of China, Annual Statistics of China 2000, http://www.stats.gov.cn/ndsj/zgnj/2000/C09c.htm). Fengxuan Xue and Dadao Lu, China's Regional Disparities: Issues and Policies (Huntington, N.Y.: Nova Science Publishers, 2001).
} 
development. They hoped the central government would give financial and policy support to champion their role in CAFTA. ${ }^{38}$

In short, various political and economic interests were at stake in the CAFTA at both national and domestic levels in China. Some of those interests were likely to be in conflict with each other, for instance MOFTEC's interest in expanding trade and MFA's concern to eliminate the perspective of a China threat in Southeast Asia, or the Chinese agriculture's expected loss and manufacturing's gain. How these interests were coordinated in the policymaking process is a major focus of the study, as will be discussed in detail in the next chapter. But apart from the interests, various ideas also entered this process to influence decision making and it is necessary to discern what they are.

\section{Domestic ideas on the CAFTA}

As analyzed in Chapter Two, the ideas held by Chinese policymakers are very important to policy outcomes in the Chinese context, especially with regards to what China's national interests are and how they should be realized. At the same time, some scholars played an important role in influencing the ideas of the government about regional economic cooperation. The think tanks affiliated with the Ministry of Foreign Affairs, MOFTEC and the Ministry of National Security, and the China Academy of Social Sciences play a close role of policy consultation for the corresponding ministries. In particular, the ideas of key economists and regional experts were particularly influential because they have been closely involved in intergovernmental dialogues and studies on regional cooperation, in which other Chinese do not have much experience or expertise. It is widely believed among Chinese scholars that Premier Zhu's idea of an FTA with ASEAN in 2000 did not come out of thin air, but from the policy recommendations for enhanced East Asian economic cooperation they had been making since

\footnotetext{
${ }^{38}$ Shengda He, Xuehong Wang, and Zhankui Gong, eds., Zhongguo-Dongmeng Ziyou Maoyiqu Jianshe Yu Yunnan Mianxiang Dongnanya Kaifang [The Construction of the ASEAN-China Free Trade Area and Yunnan's Opening to Southeast Asia] (Kunming: Yunnan People's Press, 2003). Juntao Ren, "Guangxi's Investment and Financing Measures in 'Two Corridors and One Circle' Cooperation," Around Southeast Asia, no. 5 (2006). Benzhi Shi and Jie Dai, eds., Lancang Jiang- Meigong He Ci Quyu Hezuo Yu Zhongguo-Dongmeng Ziyou Maoyi Qu Jianshe [Lancang-Mekong River Subregional Cooperation and the Construction of China-ASEAN Free Trade Area] (Beijing: China Commerce and Trade Press, 2005).
} 
the mid 1990s. This section will summarize the important ideas of Chinese policy elites related to regionalism and the CAFTA, as they inform why China forged an FTA with ASEAN, and why the CAFTA has taken certain forms.

\subsection{China's diplomatic style}

After the Tian'anmen Square incident in 1989, Deng Xiaoping declared the central principle for China's diplomacy should be 'tao guang yang hui' [hide the sharpness and accumulate strength]. That means China should not be proactive or assertive in international arenas, but focus on domestic development. Accordingly, a Chinese economist holds that "we have to realize that the economic status of Japan in Asia cannot be replaced by China in a short term, at least in 20 years...We should be realistic, flexible and practical, 'hide the sharpness and accumulate strength' and strengthen our power soon." ${ }^{39}$ Therefore China had since been cautious about initiating regional cooperation for fear of being regarded aggressive or ambitious to become a hegemon. China had also avoided institutionalized or binding economic cooperation as much as it could because that would require China to surrender part of economic sovereignty, which involved risks to national strategic and economic security. Indeed this lowprofile, flexible diplomatic style helped China regain international opportunities lost in 1989 for economic growth and to some extent reduced the worries of its neighbouring countries.

However, after a decade's reform and opening, China has not only increased its economic power but also the knowledge of the outside world, therefore changes have happened in the diplomatic thinking which now advocates that China should play a more confident and active role in global and regional free trade. ${ }^{40}$ Moreover, the lack of a clear stance in international arenas was impeding the third-generation Chinese leadership's effort to build the image of China as a responsible great power in the region and in the world. Chinese policymakers realized that if China continued to languish outside institutional economic cooperation, China would be in a passive position in global competition. "China should participate in regional economic cooperation with purpose and emphasis." 41

\footnotetext{
${ }^{39} \mathrm{Xu}, \mathrm{Li}$, and Li, China Leading the Race, 148.

${ }^{40}$ Ibid., 153.

${ }^{41}$ Ibid., 155.
} 
In the discussions in China after the Asian financial crisis on how to utilize the political credit China earned in the region and how to build an East Asian Community, one agenda was certain, namely, China would increase its activism and weight in East Asian regional cooperation. According to officials at the Ministry of Foreign Affairs, the principle of tao guang yang hui has not been abandoned; rather, it has taken an updated form, whereby China tries to influence East Asian regional affairs through indirect channels such as forging economic cooperation and influencing ASEAN. That was because the foreign policymakers reached the conclusion in the late 1990s that it was 'also important' for China to 'yu shi ju jin' [move on with time]. "Don't forget," they claim, "Deng Xiaoping also told us to 'you suo zuo wei' [do and achieve]. ${ }^{, 42}$

\subsection{The relationship between multilateralism and regionalism}

From the mid 1980s to the mid 1990s, China made a lot of efforts in expanding global economic nexuses. Besides, China was a major advocate of the Non-Aligned Movement in the 1950s. In the late 1990s, however, the Chinese foreign economic policy shifted from only multilateralism to both multilateralism and regionalism as instruments of international economic cooperation. This section will briefly depict China's participation in multilateral economic cooperation, its increasing activism in regionalism and the perceptions of Chinese policymakers on the relationship between multilateralism and regionalism.

\section{Multilateralism}

China started international economic cooperation through a global approach at first. The decision to become part of global economic institutions was the result of ideological and practical debates in China, as well as active engagement of those institutions with China. Chinese leaders including Mao and Deng used to regard international organizations as mechanisms set up by Western countries to dominate and exploit the developing world. However, China's economic development demanded sources of capital and market outlets that no unilateral or regional effort alone could provide. Membership in the World Bank and IMF was sought following the suggestion by visionary Chinese economists. During the interaction

\footnotetext{
${ }^{42}$ Interview with MFA officials in Beijing on 10 April 11 May, 2006.
} 
between the Chinese government and the two organizations, China gradually realized that international organizations were not necessarily exploitative, but indispensable for China's economic development and international status. Confidence was built on both sides between China and the organizations about each other's sincerity and desire for cooperation. Mutual adjustments were also made to accommodate each other's conditions. ${ }^{43}$

After China went through the annual examination of its MFN status by the US Congress for many years, the Chinese leadership believed it was necessary to join the WTO, despite the anxiety of domestic sensitive sectors. China pursued for fifteen years a quest to resume its GATT/WTO membership in order to secure equal market status for its exports. The international negotiations and Chinese domestic politics on China's WTO accession were difficult, but for such a huge economy as China, no international organization is complete without its participation, and China cannot afford to be excluded from the organizations where major international economic rules are negotiated and established. Being more confident and pragmatic, China entered the WTO with a call for 'a fair and rational international economic order', and a triumphant spirit that it was time China played a leading role on the global stage. In the eyes of many Chinese, the WTO accession was a benchmark success of Chinese economic diplomacy, signifying China's commitment to global economic cooperation and the recognition of China's importance by the world community.

The WTO membership has not brought as many benefits as many Chinese had expected. First, China sought WTO membership in the hope of gaining free access to foreign markets, "but now it finds the system is not as 'liberal' as it had anticipated". ${ }^{44}$ That view is caused largely by the number of anti-dumping cases against China. China has not only faced a much higher number of anti-dumping complaints than any other WTO member from 1995 to 2007, but also more cases after the WTO accession than before. ${ }^{45}$ That may be partly because China's increased access to global markets caused other countries to be more sensitive to Chinese

\footnotetext{
${ }^{43}$ Harold K. Jacobson and Michel Oksenberg, China's Participation in the IMF, the World Bank, and GATT: Toward a Global Economic Order (Ann Arbor: The University of Michigan Press, 1990).

44 "Bo: China Deserves Market Economy Status," China Daily, June 25 2004, "China Deserves Market Economy Status," China Daily, May 172004.

${ }^{45}$ By 30 June 2007, China has been the target in 551 anti-dumping cases at the WTO, more than one sixth of the 3097 cases in total. See WTO statistics on anti-dumping initiations by exporting country available online at http://www.wto.org/english/tratop_e/adp_e/adp_e.htm, accessed on 21 Feb. 2008.
} 
exports, but China blames the situation on its 15 -year non-market economy status as stipulated in its WTO accession protocol. The non-market economy status is seen by China as "unfair" and “discriminatory", a "wild card used in some countries' hands to contain China’s exports and shield local industries". ${ }^{46}$ Second, opinions vary among Chinese domestic industries over whether trade liberalisation has been beneficial to them. Some sectors in heavy industry, such as automobiles, might be doing better than they had expected. Some other sectors, agriculture for instance, have intense debates over whether too much concession was made under WTO and whether further liberalisation would be destructive. They think it is unfair that some major countries still have high tariff or non-tariff protection of their agriculture. Reviews on China's implementation of commitments made upon WTO accession have come to mixed conclusions as well, acknowledging China's tariff reduction schemes but disappointed with the progress on trade-related issues such as intellectual property rights, investment policies and implementation at the local level. ${ }^{47}$ All those signs show that China is still 'feeling for the stones to cross the river $^{48}$ of economic liberalization, especially cautious about the participation in multilateral economic organizations. It is evident that China still has difficulty and hesitation about swift, comprehensive liberalization.

\section{Regionalism}

Since the late 1990s, a notable feature of China's economic diplomacy has been its increasing activism in regional economic cooperation, the momentum of which seems to even have surpassed that of China in global economic cooperation.

According to Chinese policymakers and scholars, this policy shift came against the background of several international developments: FTAs proliferated in the world; China gained political credit in the region during the Asian financial crisis and started thinking how to spend

\footnotetext{
46 "China's EU Policy Paper (2003/10/13)," ed. China's Permanent Mission to the UN Office at Geneva and Other International Organizations in Switzerland (available online at http://www.chinaun.ch/eng/xwdt/t88637.htm, 2003). Yongtu Long, Statement by Mr. Long Yongtu, Assistant Minister of Foreign Trade and Economic Cooperation, People's Republic of China at the Ministerial Conference of WTO in Singapore (http://www.wto.org/english/thewto_e/minist_e/min96_e/st117.htm) (September 1996 [cited 29 August 2006]).

${ }^{47}$ Terence P. Stewart, "China's Compliance with World Trade Organization Obligations: A Review of China's 1st Two Years of Membership," U.S.-China Security and Economic Review Commission, 2004 Margaret M. Pearson, "China's WTO Implementation in Comparative Perspective: Lessons from the Literatures in Trade Policy and Regulation," The Review of International Affairs 3, no. 4 (Summer 2004).

${ }^{48}$ Deng Xiaoping's famous phrase for China's approach to economic reform and opening up.
} 
it; China finished negotiations on the WTO accession with major countries; the Chinese embassy bombing in Yugoslavia in March 1999 led to a deterioration in Sino-US relations; and Japan became more proactive in promoting East Asian economic cooperation. Chinese policymakers view the proliferation of regional economic integration since the 1990s as a historical trend and the result of world economic development. China should 'advance with the trend of the era', and participate actively in global and regional economic integration, otherwise China would lose its market share and other international opportunities. ${ }^{49}$ When China completed the WTO negotiations with major countries, in particular the US in 1999, the Chinese trade policymakers regarded the WTO membership as a channel for China's long-term trade expansion, as the WTO negotiations make slow progress. Moreover, after the WTO accession, the rate of increase of China's exports was not as fast as they expected, partly because of nontariff barriers and trade disputes. Therefore, Chinese policymakers believed China needed to look for short-term and alternative strategies to accelerate market access, now that the WTO membership would not be jeopardized and China's trade policymaking institutions had more bureaucratic capacity to spare with. ${ }^{50}$ As stated in the government's $11^{\text {th }}$ Five-Year Plan, regional economic cooperation has become a national strategy.

However, China has not abandoned multilateralism. On the potential adverse effects of regionalism for multilateralism (for instance, trade diversion and the 'spaghetti bowl' effect on international trade), ${ }^{51}$ Chinese policymakers argue that FTAs and the WTO are not contradictory but supplementary to each other. Chinese trade policymakers are aware that "FTAs are exceptions to the Most-Favoured-Nation (MFN) treatment of the WTO",52 but they argue FTAs

\footnotetext{
${ }^{49} \mathrm{Xu}, \mathrm{Li}$, and Li, China Leading the Race, 30. Zhang and Zhou, eds., East Asian Cooperation, 103-05.

${ }^{50}$ Interview with a trade official in Beijing on 14 April 2006.

${ }^{51}$ Trade diversion refers to the situation when trade is diverted from a more efficient exporter towards a less efficient one because the latter joins an FTA, while trade creation refers to the increase of trade between members of FTAs. See Jacob Viner, The Customs Union Issue (New York,: Carnegie Endowment for International Peace, 1950). 'Spaghetti bowl' is an analogy used first by Jagdish Bhagwati to refer to the effet of trade segmentation caused by complex Rules of Origin in FTAs. See Jagdish N. Bhagwati, Pravin Krishna, and Arvind Panagariya, Trading Blocs: Alternative Approaches to Analyzing Preferential Trade Agreements (Cambridge, Mass.: MIT Press, 1999). For the debate on the relationship between regionalism and multilateralism - whether FTAs are stepping stones or stumbling blocks for global trade liberalization, also see Jo-Ann Crawford and Sam Laird, "Regional Trade Agreements and the WTO," North American Journal of Economics and Finance 12, no. 2 (July 2001). Nicholas Lockhart and Andrew D. Mitchell, "Regional Trade Agreements under GATT 1994: An Exception and Its Limits," in Challenges and Prospects for the WTO, ed. Andrew D. Mitchell (London: Cameron May, 2005).

${ }^{52}$ MOFCOM, "Director of the International Economic and Trade Relations Department Yu Jianhua talks
} 
are legal under the WTO and have become a common practice by other countries. Many Chinese policymakers state that the WTO explicitly acknowledges the legality of FTAs. When Beijing was considering Hong Kong's proposal of an FTA with the mainland, Chinese Vice Minister of MOFTEC Long Yongtu commented that the establishment of such an area was totally in line with the WTO regulations, and this view was supported by Mike Moore, then Director General of the WTO, who cited the examples of the EU and NAFTA ${ }^{53}$ Chinese trade policymakers hold that the multilateral trade regime cannot completely replace regional economic organizations in promoting the economic development and trade between regional members. For one, they argue, trade liberalization is easier to negotiate in a small group of countries. Second, regionalism enhances the ability of members to adapt to multilateral liberalization.

In fact, multilateralism and regionalism play different roles in China's foreign economic policy.

Internationally, multilateralism is used for China's global economic interests, to gain access to global markets on an MFN basis, to participate in international rules making, and to build China's international image of a responsible great power. Regionalism is used to pursue objectives beyond the areas that the WTO covers, such as to gain resources and energy, to ensure economic and geopolitical security, to strengthen Beijing's relations with and influence on (potential) strategic partners, to obtain more access to targeted markets beyond the level granted by the WTO, to make the rules of the region, and to raise China's voice in global arenas through the group. Chinese policymakers claim that the mindset of spheres of influence is out of date. Rather, "if the most important thing of China's entry into the WTO is to obey the rules of the game, the negotiations of the CAFTA will be the start of China in making the rules of the game." ${ }^{, 54}$

Domestically, multilateralism is in a sense used by the Chinese leadership to impose reforms on difficult domestic sectors and to lock in reform in the future. Regionalism, in

about Free Trade Areas and Regional Economic Cooperation," 2006, http://www.mofcom.gov.cn/fangtan/061229.shtml (29 Dec. 2006).

53 "China considering to set up special trade area: Long Yongtu", People's Daily (English), 29 Nov. 2001.

${ }^{54} \mathrm{Xu}, \mathrm{Li}$, and Li, China Leading the Race, 163. A similar view can be found in Zhang and Zhou, eds., East Asian Cooperation, 129-31. Zhang and Zhao, eds., Asia Pacific Cooperation, 14. 
contrast, is pursued to 'lock in' the international economic opportunities for Chinese domestic actors under China's given economic conditions. Although domestic reforms were costly, the WTO accession was imperative to the Chinese leadership because it was linked with China's national pride as a great power that deserved equal trading rights as most other countries, the international recognition of China's reform efforts to build a market economy, and the government's (including leaders like Jiang Zemin and Zhu Rongji) competency in international negotiations. Such an imperative is lacking in China's FTA endeavours; nor are FTAs closely associated with national pride or do they receive much media coverage until they are signed. Therefore if an FTA would require costly domestic adjustments, it is questionable whether the Chinese policymakers would propel its formation with the same extent of commitment. Since so little about FTAs has been discussed in public in China during their negotiations, the leadership's competency would not be in public doubt even if it could not deliver a promise to the partner country - for the insiders at government agencies, it only meant that the leadership chooses not to exert more pressure.

\subsection{Models of Asian Integration and China's identity in the region}

During the Asian financial crisis, China was one of the East Asian countries that realized the necessity of regional economic cooperation. Chinese policymakers and scholars started to think seriously about how to realize it. As part of a wider discussion in the region, Chinese scholars envisaged several theoretical models of East Asian integration and debated about their viability. They included merging three ASEAN +1 mechanisms, Southeast Asia and Northeast Asia (ASEAN+3), or directly East Asia together. ${ }^{55}$ As the following discussions show, not all models were supported or considered feasible by Chinese officials, not least because of the deep political distrust for Japan.

\section{East Asia}

Chinese scholars were enthusiastic about East Asia integration and believed China would play a central role in it. They hold that only when Japan and Korea are included can there be a

\footnotetext{
${ }^{55}$ Zhang and Zhou, eds., East Asian Cooperation, 8-12. Xin Sun and Changwen Xu, Zhong Ri Han Jingji Hezuo Cujin Dongya Fanrong [China-Japan-Korea Economic Cooperation for East Asian Prosperity] (Beijing: China Customs Press, 2005)
} 
tri-polar global economic structure. East Asian regionalism can be a geographical buttress for China to participate in economic globalization, to propel multi-polarity in the world, to curb the hegemonic intention of the US in Asia, as well as a platform for China to play the role of a great power. ${ }^{56}$

Countering the view that China's export growth has placed severe competition pressure on neighbouring countries, especially on the latter's labour-intensive industries, they argue that through processing trade with China, these countries actually obtained access to the cheap labour of China, reduced production costs and expanded markets. China has become an important export market for other East Asian countries as its trade surplus increased the income of Chinese consumers. Chinese economists claim that China's role in increasing the market size of East Asia was an important factor in the 'East Asian Miracle'. ${ }^{57}$ Moreover, China has provided opportunities for its investor countries to transfer industries in order to create domestic space for developing new industries. Given China's multi-level economic structure across industries and provinces, China can complement countries of different levels of economic development. ${ }^{58}$

In a bold attempt of East Asian countries, the East Asian Vision Group was established to design the architecture of East Asian integration as a whole, at the suggestion of the South Korean Prime Minister Kim Dae-jung at the 1998 ASEAN+3 Summit. The East Asian Study Group's report proposed an East Asian Community as the policy objective of regional cooperation to the political leaders at the 2001 ASEAN+3 Summit. At the Summit, Kim Daejung also raised the idea of establishing an East Asian FTA. According to a Chinese think tank, "The leaders of ASEAN countries were not as enthusiastic to this idea as to the CAFTA, and shelved it to the next Summit." ${ }^{59}$ Many Chinese scholars and foreign economic policymakers admit that the main problem with East Asian integration has been the lack of trust between China and Japan, especially among their foreign policy policymakers.

\footnotetext{
${ }^{56} \mathrm{Xu}, \mathrm{Li}$, and Li, China Leading the Race, 147.

57 Ibid., 44.

58 Ibid., 46.

${ }^{59}$ Ibid., 147.
} 


\section{ASEAN+3}

Other models suggested more gradual and realistic approaches to East Asian integration. For the benefit of regional political security, China paid much attention to both ASEAN +1 and ASEAN +3 cooperation mechanisms. Jiang Zemin, Zhu Rongji and Hu Jintao participated in both Summits. Moreover, ASEAN +3 has delivered results in financial cooperation, starting from the Chiang Mai Initiative in 2000. Major decisions on East Asian financial cooperation have since been held at ASEAN+3 Finance Ministers' Meetings. The government has decided the principle of China's participation in various regional cooperation mechanisms: "participate actively, expand shared understandings, increase mutual trust, and strengthen cooperation." ${ }^{60}$

Chinese scholars were divided into two groups on China's first choice of partnership within East Asia. One is the ASEAN+3 model, that is, to pursue China-Korea-Japan cooperation first, as the Northeast Asian half of East Asian integration, before bridging with the Southeast Asian half. In the view of economists at IFTEC and those at CASS, China's economic cooperation with Japan and South Korea made more sense than that with ASEAN because China's economic structure and development level were much more 'complementary' with the former two countries. It would not be so meaningful for China to forge economic cooperation with a small economy like ASEAN with similar product structures to China ${ }^{61}$ In November 2002, China stated that the three Northeast Asian countries would start discussions about establishing an FTA. Informal discussions went under way between the three countries about the possibility of trade liberalization among them, only to discover immense difficulty in overcoming domestic protectionism particularly in Japan and Korea on the one hand, and deep political distrust between China and Japan on the other. ${ }^{62}$ Although the ASEAN +3 mechanism achieved the Chiang Mai Initiative for financial cooperation, Chinese scholars judged that ASEAN +3 would remain a regional economic forum for a long time before it became a real regional organization. ${ }^{63}$

\footnotetext{
${ }^{60}$ Ibid., 32.

${ }^{61}$ Interviews with scholars in Beijing on 1, 8, 9 March 2006.

${ }^{62}$ Zhang and Zhou, eds., East Asian Cooperation, 138-62. Zhang and Zhao, eds., Asia Pacific Cooperation, 130-31.

${ }^{63} \mathrm{Xu}, \mathrm{Li}$, and Li, China Leading the Race, 103.
} 


\section{$\operatorname{ASEAN}+1$}

The other group of Chinese scholars, including those more concerned with politics, prioritized China's partnership with ASEAN, as one of the three hub-and-spoke ASEAN+1 mechanisms, among the models of East Asian integration. In their opinion, because ASEAN countries were weaker economies than Japan and Korea, they posed lower economic risk to China in its first trial of formal regional cooperation. ${ }^{64}$ They believed that cooperation with ASEAN would also be easier to realize because ASEAN was politically closer to China than Japan was. For Chinese policymakers, China had to be confident in the negotiations, and had to make China's first attempt at formal regional economic cooperation come to fruition. ${ }^{65}$ In other words, China's economic security and face are equally important. Therefore, as the most plausible and necessary step of China's participation in East Asian regionalism, the cooperation with ASEAN became prioritized by policymakers.

It is worth noting that China did have a 'big country' mentality in the formation of the CAFTA, which implies China would give concessions to its beneficiaries. "The proposal of ASEAN and the preferential trade arrangements for the three least developed countries (Laos, Myanmar and Cambodia) are proof that China is genuinely propelling East Asian cooperation and that China would not avoid its dominant role as a great power. ${ }^{, 66}$ Chinese policymakers deny that China had the aim of resuming the ancient 'tributary system' with ASEAN. They reason that in ancient tributary system, China guaranteed other countries' peace in exchange of (symbolic) goods (i.e., tributes). Now it is the opposite - China is seeking peaceful and close relations through economic exchange and (inter-)dependence. ${ }^{67}$ This is quite contrary to a general pattern observed by Freund that large countries (like the US and the EU) extract greater trade concessions from small countries in free trade agreements. ${ }^{68}$

\footnotetext{
${ }^{64}$ Interviews with scholars in Beijing on 1,8 March 2006.

${ }^{65}$ Interview with a trade official in Beijing on 23 March 2006.

${ }^{66} \mathrm{Xu}, \mathrm{Li}$, and Li, China Leading the Race, 163.

${ }^{67}$ Interview.with MOFCOM officials, Beijing, March 2006 and April 2007. Zhang and Zhou, eds., East Asian Cooperation, 221-22.

${ }^{68}$ John Ravenhill and Yang Jiang, "China's Move to Preferential Trading: A New Direction in China's Diplomacy," Journal of Contemporary China 18, no. 58 (2009). Caroline Freund, "Reciprocity in Free Trade Agreements," World Bank Working Paper, no. 3061 (2003). Also see Ann Capling, All the Way with the USA: Australia, the US and Free Trade (Sydney: University of New South Wales Press, 2005). Robert Zoellick, "Unleashing the Trade Winds," The Economist, 7 December 2002. Jeffrey J. Schott, "Assessing US FTA Policy," in Free Trade Agreements: US Strategies and Priorities, ed. Jeffrey J. Schott
} 
A sentence from an IFTEC publication is accurate in its summary of the Chinese view on the models of East Asian regionalism and regional China's identity: "The CAFTA lays a foundation for a new East Asian politico-economic order, and increases China's momentum to become an economic superpower as well as the regional leader." ${ }^{29}$

\subsection{The relationship between East Asian regionalism and APEC}

Discussions on regional economic cooperation gained momentum in China as part of the wider academic discussion of regional cooperation in East Asia and Asia Pacific, when the developments of the EU and NAFTA became more substantial in the mid 1990s. In academic discussions within China, the realization of Asia Pacific economic integration, and China's participation in it, was placed in tandem with the narrower East Asian cooperation, and at times seemed more lively and plausible than the East Asian one, given the American presence in the region. At least, East Asian cooperation was regarded as a step towards Asia Pacific regional economic integration. ${ }^{70}$ The experts at the Asia Pacific Institute of CASS were attentive participants to regional track-two dialogues and advocates of this endeavour in China.

For the modus operandi of APEC, China has emphasized 'open' regionalism - inclusive, non-discriminatory - voluntary and unilateral liberalization, and economic and technological cooperation rather than a compulsory institution. When the US proposed the ambitious Early Voluntary Sectoral Liberalization (EVSL) program, the developing countries were alerted to the intention of the developed countries in APEC to use it as a vehicle for negotiated trade liberalization to their advantage.

The Asian financial crisis propelled China's first decisive move in 'narrower' regionalism in two ways. First, as mentioned previously, the crisis provided a platform for China to showcase its generosity and credibility to its East Asian neighbours. By not devaluing the Chinese currency and lending some money to the worst-hit countries in the crisis, China overshadowed Japan and the US and gained credit almost as a saviour of the region. The Chinese policymakers considered that as an opportunity for China to increase and embed its

(Washington D.C.: Peterson Institute, 2004).

${ }^{69} \mathrm{Xu}, \mathrm{Li}$, and Li, China Leading the Race, 194.

${ }^{70}$ Interview with scholars on 1, 8 March 2006. 
influence in East Asia. ${ }^{71}$ Second, the crisis changed the policy focus in both the regional and domestic discursive environments of China from an emphasis on Asia Pacific to East Asia. During the crisis, APEC did not provide effective measures to protect its members from financial malaise, which directly led to its falling from the leading position of regional economic cooperation mechanism for Asian countries. The enthusiasm of Chinese scholars for Asia Pacific cooperation dimmed as East Asian countries became more sceptical about the US and increased their enthusiasm for an East Asian Community.

A Chinese scholar argued that "APEC cannot represent the interests of Asia because it is dominated by developed countries (led by the US) which seek to open the markets of developing countries." ${ }^{, 2}$ According to a former Chinese diplomat, as long as the US is involved, China cannot entrust APEC with parts of its political or economic autonomy or let the mechanism become institutionalized. ${ }^{73}$ His attitude is reflected in Chinese officials' continued insistence that APEC remain a mechanism focused on promoting technological cooperation between developed and developing countries. A related example is China's attitude towards the East Asia Summit. China opposed the attendance of countries from outside East Asia before the first Summit was held. When the attendees eventually expanded to include Australia, New Zealand and India, the Chinese government decided not to substantiate or promote the Summit any more as a mechanism for regional cooperation, although China appears to be supportive for subsequent summits in order to remain an important party to this mechanism. Moreover, Chinese trade officials do not think trade liberalisation is possible in APEC, because the potential problems have already been exposed in the WTO negotiations. Besides, there are subgroups in APEC, such as NAFTA and Australia-New Zealand Closer Economic Relations (CER), but Asian countries lack a collective voice, since ASEAN was weakened by the Asian financial crisis. Most Chinese policymakers and scholars, including those in the APEC Study Centres, point out that the loose structure of APEC cannot force members to cooperate. ${ }^{74}$

\footnotetext{
${ }^{71}$ Interview with trade officials on 23 March, 10 April, and a scholar at CASS on 8 March 2006 in Beijing.

${ }^{72} \mathrm{Xu}, \mathrm{Li}$, and Li, China Leading the Race, 135.

${ }^{73}$ Interview in Beijing on 11 May 2006.

${ }^{74}$ Zhang and Zhao, eds., Asia Pacific Cooperation, 25.
} 
In general, APEC has receded from among the major models of Asian economic cooperation in the view of Chinese policymakers. Still, the earlier participation in APEC has increased China's confidence in its skills in regional economic cooperation, consolidated the crucial role China plays among major countries in the region and convinced regional members of the deep impacts of China's rise on regional dynamics. On the other hand, some policymakers think the experience and lessons gained from the CAFTA and East Asian cooperation will be beneficial for China if wider cooperation in Asia Pacific becomes imperative in the longer term. ${ }^{75}$

\subsection{The choice between conflicting interests}

The ideas on the relationship between national strategic and economic interests, and between international and domestic economic interests are crucial for the foreign economic policy choices.

The preceding analysis shows that China's foreign economic policies serve both strategic and national economic interests. Strategic objectives are particularly important in China's regional economic cooperation. What does the Chinese state choose then between strategic interest and economic interest when the two are in conflict? The rhetoric of the Chinese officials and scholars does not give a direct answer, but it is ostensible that state security is given top priority, for it concerns the survival of the regime. However, if the strategic importance does not rise to the level of state security, the choice depends on the preference of the leadership, the relationship or power distribution between government foreign policy and foreign economic policy institutions, and among all the domestic actors who participate in the policy making, as will be discussed in detail in the next chapter.

As much as the Chinese FTA negotiators try to avoid it, if China's international economic interests in an FTA (access to overseas markets, attracting investments) require liberalizing and reforming domestic economic sectors at certain costs, would China sacrifice domestic interests for gains from the partner countries, or protect the domestic economic sectors instead? Although Deng Xiaoping and Zhu Rongji were prominent political leaders who believed liberalization

\footnotetext{
${ }^{75} \mathrm{Xu}, \mathrm{Li}$, and Li, China Leading the Race, 136. Zhang and Zhao, eds., Asia Pacific Cooperation, 120-28.
} 
was beneficial for the growth and development of the national economy, domestic welfare has become increasingly important for the legitimacy of their successors as the overemphasis on growth over development has started to threaten social stability. Some Chinese foreign economic policy elites believe that China will have to pay costs of deepening economic adjustments during regional economic cooperation; however, from a long-term view, memberships at the WTO and regional economic cooperation will ameliorate the international environment of industrial development and enhance the structure and quality of industrial products. Moreover, they predict that benefits will outweigh costs for China under the new regional order. ${ }^{76}$ Again, specific policy choices depend on the preference of the policymakers, as influenced by various international and domestic forces.

In summary, various interests and ideas at both national and domestic levels were involved in China's policymaking on the CAFTA. The state had more strategic and political motivation than economic motivation in forging the FTA with ASEAN, but the trade policymakers still hoped economic potentials would be explored to benefit China in the long term. Some domestic sectors would be adversely affected by the CAFTA, mostly agriculture, as would the agricultural provinces bordering ASEAN countries. As it turned out, China did open agriculture to ASEAN first, which imposed costs for those provinces. Some manufacturing sectors would gain from the CAFTA but because some were excluded from tariff reduction, they lost market opportunities (although these were not large in relation to China's global sales). Did the agriculture sector try to influence the government to protect them? Did the manufacturing sectors try to push the government to open the ASEAN market? What factors were decisive in the government's final decisions to make those sacrifices and concessions? As will be discussed in the next chapter, China's policymaking process of the CAFTA was not a simple story of an authoritarian state. In fact, increasing dynamics have taken place during the policymaking process between central foreign economic policymakers and domestic industries, between the central and local governments, and between the state and private sectors.

${ }^{76} \mathrm{Xu} 2003,194$. 


\section{Chapter 4 China's Policymaking Process for the China-ASEAN Free Trade Agreement}

As analyzed in the previous chapter, some domestic economic interests in China have been sacrificed by the Chinese government in the China-ASEAN Free Trade Agreement (CAFTA) - for instance, to reduce tariffs in agriculture, and let ASEAN countries keep protection over some manufacturing products. Was it the case that the Chinese central policymakers were so preoccupied with China's strategic interests that they did not mind economic interests at all when they made the policies with ASEAN? Or as some ASEAN countries suspect, was China aiming at long-term benefits by giving short-term concessions in order to get ASEAN onboard the FTA? Why could the Chinese central policymakers exempt some sectors and not others from reduced tariffs on imports from ASEAN? Considering agriculture is traditionally difficult for trade liberalization in other countries as well as in China's WTO negotiations, how has China managed the fast growing agricultural imports from ASEAN, particularly in the most severely affected provinces? Is the conventional wisdom correct that the Chinese state was so authoritarian that domestic interests simply remained silent about the potential costs they would incur during the formation of the policies and the implementation period? Have they simply succumbed to the state authority?

This chapter answers those questions by looking into the formation of China's policies towards the CAFTA in a chronological order. To be sure, the stages here are rough divisions of the policymaking process for the purpose of description and analysis. Some developments in the dynamics of the policymaking were in fact gradual and constant. The focus is on how the interests and ideas in China, as introduced in the previous chapter, interacted with each other under certain institutional settings during each major step of the policymaking process of the CAFTA so that some prevailed over others and produced particular policy outcomes. I will suggest that although the initiation and early developments of the CAFTA was directed largely by Beijing's strategic motivations through the domination of the leadership and the Ministry of Foreign Affairs in policymaking, later developments during formal FTA negotiations have been increasingly constrained by the economic interests of domestic local and industrial actors because the lead agency - MOFCOM — was more concerned with national economic interests 
and less insulated from domestic interests than MFA was, and industrial ministries or local governments became more vocal as they learned more about their stakes in the FTA. Ideas held by Chinese scholars about regionalism played an important role in terms of providing the leadership with a cognitive source for the policy initiative as well as expert support for arguing the feasibility of the CAFTA. However, their involvement was largely invited by the government and learning by policymakers themselves about regionalism has been crucial in their design of strategies of economic diplomacy as well as institutions for domestic policymaking.

\section{Initiation}

As introduced previously, the central motivation of the Chinese leadership to initiate an FTA with ASEAN was political and strategic, primarily to address ASEAN's worries about China's economic and political rise. In particular, when it became a member of the WTO, China had the potential to pose a severe competitive threat to ASEAN's domestic industries in domestic and export markets, and to draw away foreign direct investments. At the same time, ASEAN still felt threatened by China's military power in the Taiwan Strait and the South China Sea. At the 2000 ASEAN-China Summit in Singapore, ASEAN leaders raised their concerns to then Chinese Premier Zhu Rongji and asked China to pay special attention to their economic interests. Zhu responded that China and ASEAN could explore the possibility of a free trade relationship.

Among Chinese bureaucrats and academics, there are two versions of the story how Zhu Rongji had the idea of a free trade area as the specific form of cooperation with ASEAN. In one version, according to some Chinese scholars, it was suggested by Chinese members of the delegation accompanying Zhu to Singapore. At the Summit, while expressing their worries, ASEAN requested China to develop economic cooperation (implying preferential treatments) with them. In response, Zhu Rongji promised to have "a long-term arrangement" with ASEAN. ${ }^{1}$ Since China had already gained experience in international economic cooperation through WTO

\footnotetext{
${ }^{1}$ According to Carlyle Thayer, Zhu said "In the long term, China and the ASEAN countries can also further explore the establishment of a free trade relationship." Quoted in Lijun Sheng, "China-ASEAN Free Trade Area: Origins, Developments and Strategic Motivations," ISEAS Working Paper: International Politics and Security Issues Series, no. 1 (2003): 88
} 
negotiations, the remaining important issue was to 'locate' (meaning operationalize, materialize, or decide the form of) the arrangement well so that it could effectively allay ASEAN's worries and strengthen bilateral ties. At the end of the first day of meetings, the Chinese delegation contemplated the issue and came up with the suggestion of a free trade area. The next day, Zhu tabled the proposal to ASEAN, which was welcomed by most ASEAN countries.

According to the other, more popular, version, the idea originated completely from Zhu himself. ${ }^{2} \mathrm{He}$ improvised it as a response to ASEAN leaders at the Summit. That is understandable because Zhu had a bold and decisive style in policymaking and was knowledgeable in economics. In the government of Jiang and Zhu, the power of determining economic policies was virtually all designated to Zhu, while Jiang watches overall political and strategic policies. Zhu's proposal surprised his accompanying delegation to Singapore-Chinese officials of the Ministry of Foreign Affairs (MFA) and MOFTEC (or MOFCOM from 10 March 2003). The surprise was embarrassing for the Chinese delegation because usually the leadership's speeches or the standpoint of the delegation would have been prepared or coordinated in advance.

Although the Chinese government ministries were not certain of the economic implications, they took immediate actions to follow Zhu's proposal and organized experts to study how to realize the FTA. The Chinese bureaucrats fully understood that once the leadership had made an international promise in public, their imperative was to implement the commitment. In the view of some Chinese scholars, Chinese bureaucrats make and implement policies by 'responding', 'following', 'managing' or 'sufficing', implying that they do not have an active policy strategy or clear agenda. After Zhu proposed the CAFTA to ASEAN, the MFA, MOFCOM and other ministries followed up closely in their respective areas of responsibility.

Whether or not the idea of negotiating free trade areas came from scholars, it is certain that they influenced the leadership's ideas on regionalism towards a more active, committed direction. It also became certain after the 2000 ASEAN-China Summit that Chinese policymakers would ensure the realization of the CAFTA. They were uncertain, however, about

\footnotetext{
${ }^{2}$ Interviews with trade officials and academics, Beijing, March to May 2006. Also see Gregory Chin and Richard Stubbs, "The Political Economy of the ASEAN-China Free Trade Agreement and East Asian Regionalism", paper presented at the International Studies Association Convention 2008, San Francisco.
} 
what form it would take or what domestic adjustments China would have to make. Therefore, a feasibility study and discussions on the framework of the CAFTA ensued.

As the initiation of China's first FTA - the CAFTA - shows, China's foray into FTAs was largely driven by strategic considerations of the state, in particular to strengthen the strategic relationship with ASEAN in order to secure its immediate strategic environment. State strategic interests were incorporated through the direct involvement of the political leadership in proposing the FTA, and through a top-down fashion of implementation by government agencies, as will be discussed in more detail in this chapter. The CAFTA is representative of many of China's FTAs, in particular with developing countries, in terms of the importance of strategic motivation and the domination of the state vis-à-vis domestic societal actors in policymaking. As the following sections suggest, those two features are also reflected in the processes of the feasibility study and negotiations of the CAFTA, although China has put more emphasis on economic gains than MFA did since MOFCOM became the lead agency after the signing of the Framework Agreement, and the state's autonomy has become more constrained by domestic interests expressed through industrial ministries or local governments.

\section{The Feasibility Study}

The two versions of the initiation story come together that an ASEAN-China Expert Group was established after the Summit as Premier Zhu suggested. The main policymaking activity of China between Zhu's proposal in 2000 and the formal decision of leaders to negotiate an FTA at the 2001 ASEAN-China Summit was a feasibility study by the ASEAN-China Expert Group, made of five Chinese experts and one or two experts from each ASEAN country. ${ }^{3}$ The study was led by the Chinese experts. The task of the Expert Group was to study two topics: first, what impact China's WTO accession would have on ASEAN; second, how China and ASEAN could cooperate for mutual benefits. During the bilateral discussions in the Expert Group in 2001, the enthusiasm and focus shifted from ASEAN's worries on China's WTO accession to the opportunities of bilateral cooperation. ${ }^{4}$

\footnotetext{
${ }^{3}$ The five Chinese experts were: Zhang Yunling, Zhou Xiaobing, Xu Changwen, Li Wei and Zeng Zhihai. Their views will be mentioned later in this chapter.

${ }^{4}$ Interview with a member in the Expert Group, Beijing, March 2006.
} 
In China, the Asia Department of the MFA organised the study and domestic consultation on the feasibility of the CAFTA. That showed the importance of strategic and political considerations in the negotiation of the CAFTA, as part of China's 'harmonious and friendly neighbourhood' [mu lin you hao] diplomacy.

The policymakers explained that only academics were invited into the domestic consultation process because they were not biased by the narrow interests of domestic industries or provinces, and that their views were theoretically-informed. But it is noticeable that this group of five consisted of Chinese experts from the Institute of Asia Pacific Studies of CASS, the Institute of Foreign Trade and Economic Cooperation (IFTEC) under MOFTEC, all of whom had close contacts with and were chosen by the central government. No ASEAN experts from local academic institutes in Fujian, Guangdong, Guangxi or Yunnan were involved although some are prominent scholars on ASEAN politics and economies. Scholars in those provinces have participated indirectly in the policymaking by assisting local governments assess the implications of the FTA for local economies, although how much influence local governments have on central decision varies (for instance the provinces have had a greater influence in the case of Australia-China FTA than in CAFTA). As will be discussed later, in the case of the CAFTA, local governments did not have much say in policy formulation but in implementation and feedbacks.

The experts from the CASS had been proponents of Asian regionalism, as well as active participants in track-two dialogues on regional integration. They were keen on East Asia Integration or Asia Pacific cooperation as a whole. The IFTEC was affiliated with MOFTEC, specializing in the research of China's trade performances. They had been exploring the possibility of Northeast Asian cooperation as a step towards East Asian integration. To both groups of experts, the CAFTA was not the most rational agreement for China to pursue in economic terms, but they hoped the CAFTA could serve as a first step in regional integration in East Asia. Moreover, as one of the five economists believed, the objective of the CAFTA was to form triangular trade relations among China, ASEAN and developed countries (Japan, the US and $\mathrm{EU}$ ) and to 'make the cake bigger' - to enlarge the market and scale of economy - in order 
to attract foreign investments. ${ }^{5}$ Because of the small trade volume between China and ASEAN, those Chinese experts believed that the agreement was motivated more by political objectives than economic ones. But in rhetoric, while acknowledging briefly there would be challenges, the report of the feasibility study titled Forging Closer ASEAN-China Economic Relations in the $21^{\text {st }}$ Century ${ }^{6}$ emphasizes potential mutual economic benefits, and stresses in particular that China and ASEAN were complementary rather than competitive in economic endowments. Most Chinese experts and trade policymakers thought improved access to ASEAN's raw materials (such as forest and mineral resources) was the most tangible benefit that China would gain from the CAFTA. .

Before the formal report of the feasibility study was submitted to the 2001 ASEAN-China Summit, internal studies in China were also commissioned at the IFTEC and the Institute of International Economic Research of the State Planning Commission, institutes that had their own statistics and economic models. Although China was different from democratic countries, where interest groups lobby and pressure the government openly, the Chinese government tried to listen to opinions from various sources through internal channels. Chinese policymakers had by then realized that foreign economic policymaking should be sophisticated and somewhat scientific - that they should know about the potential costs and benefits of a policy for the domestic economy - although domestic interests would have to give way, if necessary, when they conflicted with the national interest. The internal report submitted by IFTEC to MOFTEC expressed worries about China's potential economic costs, particularly in agriculture and some services. But the report was revised before it became part of the final version of the Feasibility Study to show more benefits rather than challenges for China. ${ }^{7}$ As will be discussed in the next Chapter, this revision was in contrast with MOFCOM's opinion on the draft Feasibility Study of the Australia-China FTA - the MOFCOM insisted that the study underestimated the potential costs to the Chinese economy.

\footnotetext{
${ }^{5}$ Interview with a member in the Expert Group, Beijing, March 2006. Also see Chalongphob Sussangkarn, "Thailand and the China-ASEAN FTA," Thailand Development Research Institute Quarterly Review (March 2003). Suthiphand Chirathivat, "ASEAN-China Free Trade Area: Background, Implications and Future Development," Journal of Asian Economics 13, 5 (2002): 671-86.

${ }^{6} \mathrm{http}: / /$ www.aseansec.org/asean_chi.pdf

${ }^{7}$ Interview with a researcher at IFTEC, Beijing, April 2004.
} 
The NDRC, although a legacy of the command economy, did not raise serious concerns about the proposed agreement. That was partly because the State Planning Commission was new to the research area of regional economic cooperation, and partly because other departments of the Commission whose focus was on domestic industries did not join the study. Moreover, compared with the former State Planning Commission, the influence of the NDRC on foreign economic policy apparently had been weakened in the institutional reforms in 1988, 1993 and 1998. Led by then Premier Zhu Rongji, not only were parts of the State Planning Commission's institutions being abolished in 2003 to reduce the planning element of the state's role in the economy in preparation for the WTO accession, but also the newly-formed NDRC had become largely an agency for research and advice to the central government, rather than for direction and administration of domestic industries and provinces. ${ }^{8}$ As will be discussed in the next chapter, however, the NDRC has been reinvigorated since 2004 by obtaining the power of approving investment projects when the government tried to exert more control over the national economy.

When the Chinese government announced that it would negotiate an FTA with ASEAN, not many Chinese sectors were worried except agriculture. The Ministry of Agriculture (MOA) organised its own study on the potential impact of the CAFTA on China's agriculture in view of the likely adverse repercussions of the agreement. The report was not optimistic for agricultural producers of tropical produce or raw materials in South China. On the issue of risk for Chinese agriculture, MOFTEC believed that ASEAN's tropical fruits would not have much impact on Chinese producers because tropical produce needed good storage and transportation conditions, and therefore the amount of imports would be limited and the price would be high. On the contrary, they argued, Chinese temperate fruits and vegetables were easier to preserve and much cheaper than ASEAN ones. ${ }^{9}$ The MOA thought in fact MOFTEC cared more for the potential benefits in manufacturing industries than for the costs in agriculture because it believed that big manufacturing enterprises were more powerful in China's politics and the performance of

\footnotetext{
${ }^{8}$ See the Explanations of the institutional reforms of the State Council, by Wang Zhongyu, Secretary General of the State Council, at the First Session of the Tenth National People's Congress on 6 March 2003. Online at http://www.china.org.cn/chinese/zhuanti/288054.htm, accessed on 15 January 2007. Wei Wang, "Diyi da' bu Fagaiwei hechu qu: hongguan tiaokong renzhong daoyuan [The Top Ministry NDRC Where to Go: Important Role of Macro-Economic Control]", Xinmin Weekly, 3 April 2008.

${ }^{9}$ Interview with a MOFCOM official, Beijing, March 2006.
} 
MOFTEC hinged on export expansion, which was realised mostly in manufacturing. ${ }^{10}$ To people who conducted the research for the MOA, it remained a question whether the Minister of Agriculture had circulated its report to MFA or MOFTEC; their guess was negative though, because it seemed too sensitive and confrontational to the ideas of the political leadership. ${ }^{11}$ According to a Chinese scholar, then Premier Zhu Rongji told China's trade policymakers that "we should calculate the political balance sheet". ${ }^{12}$ Anyway, the study of the MOA remained internal and other researchers swiftly reached agreement on the potential benefits of the CAFTA for China.

The Joint Feasibility Study on the CAFTA led by Chinese experts was accomplished within one year. The report Forging Closer ASEAN-China Economic Relations in the $21^{\text {st }}$ Century was submitted to the leaders at the 2001 ASEAN-China Summit in Brunei, including the suggestion to establish an FTA between China and ASEAN. The leaders of China and ASEAN endorsed the report immediately. According to MOFTEC officials, when Chinese Premiere Zhu proposed the CAFTA formally to ASEAN leaders, the latter accepted it immediately, which showed that ASEAN countries all wanted access to the economic opportunities provided by China. ${ }^{13}$

As the above process showed, like the initiation of the CAFTA, the Feasibility Study in China was led by the leadership and the MFA, and their political motivation overrode domestic concerns for agriculture. The study was conducted in a secretive manner by scholars invited by the government from quasi-governmental research institutes to ensure that the result would support the political motivation of the government. Despite the importance of feasibility studies for predicting potential impact of FTAs on the domestic economy, the government did not collect opinion or information from domestic industries at this stage. In a sense, the policymaking power was delegated by the central policymakers (the political leadership and the MFA) to experts, whose control of knowledge and information in turn insulated the central policymakers from domestic interests. As a result, the report of the study was largely optimistic,

\footnotetext{
${ }^{10}$ Interview with a MOA official, Beijing, May 2006.

${ }^{11}$ Interview with experts at the MOA and the China University of Agriculture, Beijing, March and April 2006.

${ }^{12}$ Interview with an expert on ASEAN at CASS, Beijing, March 2006.

${ }^{13}$ Interview with a MOFCOM official, March 2006.
} 
emphasizing potential aggregate gains in trade and GDP growth for both parties, without drawing attention to potential costs for some domestic sectors, which was to become a problem at a later stage.

\section{The Framework Agreement}

After the Chinese and ASEAN leaders decided to launch FTA negotiations at the ASEAN-China Summit in November 2001, Chinese embassies communicated with the trade ministries in Southeast Asia on the framework of the FTA. The MOFTEC sent a delegation in 2002 to some ASEAN countries and the Secretariat as well. It was decided by ASEAN that they would negotiate as one party with China, led by Thailand. ${ }^{14}$ In May 2002, the Third ChinaASEAN Economic Senior Officials Meeting and the first Negotiation Committee Meeting were held in Beijing, which started official discussions of the FTA. The monthly meeting decided on the principle, model, contents and framework of the FTA, which comprised the Framework Agreement. This section will discuss the preferences of Chinese policymakers for the FTA, which were generally shared by their ASEAN counterparts and reflected in the Framework Agreement.

\subsection{Symbolic or substantial}

Because the FTA was a new policy area to China and ASEAN, China's trade bureaucracies were still struggling with WTO accession in 2001, and the MFA had led the policymaking so far, observers and some Chinese elites predicted that the CAFTA would be predominantly political and symbolic,, rather than a conventional FTA in strict economic terms - one that entails wide tariff reduction between the parties. Besides, because the levels of economic development were very different among China and ASEAN countries, observers predicted that there would be a long phase of domestic and international preparation, learning, coordination, and decision making. ${ }^{15}$

Faster than the observers had expected, the CAFTA started to bear fruit through an 'early harvest' scheme. Because some ASEAN countries doubted the CAFTA would bring real

\footnotetext{
${ }^{14}$ Sompong Sucharitkul, "Report on the Second China-ASEAN Expo" Chinese Journal of International Law 5, no. 2 (2006): 397-421.

${ }^{15}$ Interview with Chinese scholars at CASS and IFTEC, Beijing, 2004.
} 
benefits to them as China claimed, China proposed an 'Early Harvest Program' for fast-track tariff reduction, as will be discussed in more detail in the next section. China also granted MFN status and preferential tariff treatments to the three non-WTO members of ASEAN (Vietnam, Laos and Cambodia) in the Framework Agreement signed in November 2002. This preferential treatment is considered by Chinese elites as an embodiment of China's 'big-country virtues and sincerity to cooperate with ASEAN' ${ }^{16}$ Besides, proposals from other countries to either China or ASEAN pushed them to substantiate the CAFTA in advance of others so that both would have the first access into the other's market.

As will be discussed later, the MOFCOM took over the leading position in the Chinese policymaking team after the Framework Agreement was signed. It ensured the accomplishment of the Agreement on Trade in Goods because the MOFCOM was more concerned than the MFA was with actual economic benefits from the FTA for China. After the WTO accession negotiations were completed, the MOFCOM not only had more bureaucratic capacity for regional affairs, but also gained confidence and experience in trade negotiations. When China met with more difficulties than it had expected in accessing markets in the US and Europe because of non-tariff trade barriers and anti-dumping lawsuits, it became more 'pragmatic' and aggressive in its search for multiple international markets. Not only developed countries were targeted but also developing countries such as Africa, South Asia, and Latin America. China's FTAs became substantial rather than symbolic.

\subsection{The AFTA model}

The model used to draft the Framework Agreement is very different from China's Closer Economic Partnership Agreement with Hong Kong or Macau. It 'borrowed' largely from the ASEAN Free Trade Area (AFTA). China's FTA with Hong Kong and Macau was aimed at complete economic integration so that political integration would be secured. Besides, Hong Kong and Macau were seen by the mainland as major sources of investment. In contrast, in the case of the CAFTA, China had no experience in forging FTAs with another country, which involved risks of losing economic sovereignty, jeopardizing security and subjecting domestic

\footnotetext{
${ }^{16}$ Changwen Xu, Guanghui Li, and Wei Li, Zhongguo Lingpao Dongya Jingii Hezuo [China Leading the Race of East Asian Economic Cooperation] (Beijing: China Customs Press, 2003), 88.
} 
industries to competition. ${ }^{17}$ In order to show China's respect for ASEAN's interests and experiences in regional economic integration, some Chinese policymakers described the CAFTA as the joining of China into the AFTA, as Premiere Zhu Rongji suggested at the 2001 Summit. Adopting the AFTA model was also a way for the MFA to emphasize ASEAN's importance in East Asian regional integration, and that ASEAN would not be marginalized by the bigger Northeast Asian economies. ${ }^{18}$

\subsection{Selective, gradual and flexible}

The Framework Agreement indicated that the CAFTA would infuse many features of Asian diplomacy into the FTA: selective instead of comprehensive tariff reduction, gradual instead of immediate implementation, and a flexible instead of a legalist approach to dispute settlement. ${ }^{19}$ According to a Chinese trade official, although China tried to liberalise trade as much as possible to sustain its big country image at the WTO, the CAFTA quoted the Enabling Clause of the GATT instead of Article XXIV because ASEAN felt the latter was too stringent, requiring parties to FTAs to attend meetings of FTA review at the WTO and to answer inquiries on the spot (the Enabling Clause only requires developing countries to submit written documents) ${ }^{20}$ Chinese officials also claimed that it was to attend to the concerns of ASEAN countries that the CAFTA included a sensitive list of products (rubber products, plastic products, porcelain products, some textiles and garments, some home electronic appliances, steel, automobiles and motorcycles) to be exempted or delayed for tariff reduction, as well as a special track of 15 years for the less developed ASEAN countries and 10 years for the other countries, provisions borrowed from the AFTA model. In the Agreement on Trade in Goods, ASEAN listed as sensitive products.

The selective and gradual approach suited not only ASEAN countries, but also China. China also excluded some sensitive products from the Agreement on Trade in Goods, including rice, natural rubber, palm oil, some petrochemical products, paper and wood products, automobiles and parts, and digital televisions. The ten-year interim phase was helpful for China

\footnotetext{
${ }^{17}$ Xu et al. 2003, 159.

${ }^{18}$ Interview with Chinese trade officials and scholars, Beijing, March to May 2006.

${ }^{19}$ Also see Wei Zhong, "Dongya hezuo zou ziji de lu [East Asian Cooperation Walks Our Own Way]," Huanqiu shibao [Global Times], 13 May 2002.

${ }^{20}$ Interview with a MOFCOM official, Beijing, April 2007.
} 
to make adjustments and policy remedies if negative impacts occurred. To address some concerns of domestic industries, Chinese policymakers assured them that the formation of the FTA would be a gradual, not an immediate, opening of all industries, therefore the possible negative impacts on domestic economy and industries could be reduced to a bearable level. ${ }^{21}$

The Framework Agreement of Comprehensive Economic Cooperation between China and ASEAN was signed between China and ASEAN at the Sixth ASEAN-China Summit on 4 November 2002 in Phnom Penh, Cambodia. Although it was only a tentative framework plan, the political promise enhanced the confidence of China and ASEAN in bilateral economic cooperation. It encompassed more fields than tariff reduction (five other areas of cooperation including agriculture, information and communications technology, human resources development, investment, and Mekong River basin development), but the FTA was intended to cover only traditional areas of trade liberalization - tariff reduction of trade in goods and services. Standards harmonization and trade-related issues were not included as part of the FTA but as areas for cooperation and facilitation.

It is worth noting that China did not demand that ASEAN recognize China as a market economy then, unlike its subsequent policy of making this a precondition for starting negotiations. In fact, China did not realize there was such an issue in FTAs until it started discussions about FTAs with Australia and New Zealand. One reason was that the domestic law on anti-dumping measures, which was needed to make the MES applicable, was not in force in China until the end of 2002. More importantly, China did not think that ASEAN would use antidumping against China because ASEAN countries were small; according to a MOFCOM official, ASEAN countries must know that anti-dumping against China could harm bilateral trade relations as well as their own economies because China takes revenge against those who target China.

The MOFTEC acknowledged that there might be adverse impacts in three aspects of the Chinese economy but it held a liberal view towards them. First, the FTA might increase China's

\footnotetext{
${ }^{21}$ Interview with trade officials in Beijing, March and May 2006. Also see Xu, Li, and Li, China Leading the Race, 185.
} 
trade deficit. However, MOFTEC suggested that many of China's imports had not been restricted by tariffs because of the government's special tariff-reduction/exemption policies such as for resources. Besides, the increase of imports had been caused by the rising domestic demand, but in recent years the domestic market had become a buyers' market and demands had already become limited. The domestic technological level of machinery and electronic products had risen significantly; so had their competitiveness in price and quality; therefore they would not be severely flooded by imported products again as they were in the 1980 s. Furthermore, the increase of imports from ASEAN had mainly been inputs for exporting industries, which was beneficial for China's economic development and export expansion.

Second, some industries might be impacted. Because of protection under the planned economy for a long time, industries would be impacted to different degrees when the market was opened. Some people might lose their job if their companies lost in the competition. MOFTEC argued that the incoming investments brought by CAFTA would bring new job opportunities and restructure the job markets. For MOFTEC, the policy of infant industry protection was questionable; it had not enhanced the competitiveness of developing countries but only enlarged the gap between developing and developed countries. For example, the automobile industry in China had been protected for over 40 years and was still an infant industry in the late 1990s. On the contrary, many Chinese companies, for instance Hisense and Haier electronics, had increased their competitiveness during the process of competing with foreign companies.

Third, by joining the FTA, China would lose some autonomy in policymaking. However, MOFTEC argued that China had to abide by rules of other international economic institutions and to reduce tariffs and non-tariff barriers to trade (NTB) under the WTO anyway. The CAFTA would just make this process faster for China's relations with ASEAN than with other countries, and would show the effects of such liberalization on a small scale and give the government and enterprises some time to adapt. ${ }^{22}$

The Framework Agreement embodied the preferences of the Chinese government for economic diplomacy when it first started negotiating FTAs: more emphasis on symbolic values

\footnotetext{
${ }^{22}$ Interviews with trade officials, Beijing, March 2006 and May 2007. Also see Ibid., 184-86.
} 
than on substantial content, the utility of the FTA to convey Beijing's political goodwill, and a selective, gradual and flexible approach to trade liberalisation. That was determined by the central role of the leadership and the MFA in the policymaking as was also the case in the stages of policy initiation and feasibility study. As a result, some of those preferences would be carried forth in China's policy towards other FTAs, while some would be changed when the leading agency changed to MOFCOM, the pressure from some domestic interests increased, and the priorities of the leadership shifted (in the case of Australia-China FTA as will be discussed in the next chapter). Before discussing some of those changes in this case, one policy in the Framework Agreement is worth highlighting - the Early Harvest Program, because it epitomised China's eagerness to win friendship from ASEAN, and a similar program was also included in China's FTA with Pakistan.

\section{The Early Harvest Program}

After Chinese Premier Zhu Rongji proposed the FTA in 2000, some ASEAN countries were not confident of the benefits of the FTA for them. At an Economic Ministers' Meeting in Myanmar in 2002, ASEAN countries expressed their lack of confidence to Zhang Shaogang, Deputy Director of the International Department of MOFTEC, and asked China to demonstrate some concrete benefits they might expect to realize. Therefore the MFA and MOTEC innovated an 'Early Harvest Program' in order to let ASEAN "pick the peaches first" and "taste the sweetness first". ${ }^{23}$ China also regarded the EHP as a 'fast track' to accelerate the implementation of the Framework Agreement, and an 'experiment field' for both sides to learn and make necessary adjustments. ${ }^{24}$

After that, Chinese policymakers decided the Program would be mainly on agriculture because agriculture had a major role in most ASEAN economies; giving concessions in agriculture would benefit ASEAN countries immensely, especially the less developed ASEAN countries like Myanmar, Laos, Cambodia, Vietnam, as well as Thailand. Besides, it would be

\footnotetext{
${ }^{23}$ Interview with trade officials and scholars.

${ }^{24}$ Guoji Shang, China-ASEAN FTA's Experiment Field: The Early Harvest Program (2005 [cited 12 Jan. 2007); available from gjs.mofcom.gov.cn/accessory/200509/1127371793253.doc.
} 
easy for officials who were involved in FTAs for the first time to tell the places of origin of unprocessed agricultural products without dealing with complicated rules of origin. ${ }^{25}$

As a result, the Early Harvest Program for trade in goods was written into Article 6 of the Framework Agreement. All products at 8/9 digit level in HS Chapters 1-8 (live animals, meat and edible meat offal, fish, dairy produce, other animal products, live trees, edible vegetables and edible fruits and nuts) were covered, and tariff concessions were multilateralized to all parties (ASEAN members and China). ASEAN countries each had an Exclusion List except Brunei and Singapore, which did not have a significant agricultural industry. During the negotiations on the EHP, some ASEAN countries wanted China to accelerate tariff reduction in other sectors too because they did not have significant trade or had trade deficit with China in goods in HS Chapters 1-8. Therefore "to balance the concession", apart from the Exclusion List, ASEAN members were allowed to submit a Request List to China on products beyond HS Chapter 8 to be included for tariff reduction. As a result, ASEAN countries except Brunei and Singapore added many products of significant export potential to China, including raw materials, electrical parts, motor vehicle parts, and microelectronics. ${ }^{26}$ Most Chinese trade policymakers and scholars regarded the EHP as a one-sided concession made by China.

As a fast track of the EHP, a Free Trade Agreement between China and Thailand on vegetables and fruits was signed on 18 June and implemented on 1 October 2003, as agreed between Chinese Premier Wen Jiabao and Thai Prime Minister Thaksin Sinawatra in April. The aim was to accelerate the liberalization of trade by both countries and show other countries the benefits of the FTA, because Thailand, especially the Thaksin government, had traditionally been a close friend to China among ASEAN countries. It backfired, however, when Chinese temperate produce (such as garlic, onion, potatoes and apples) caused a problem for farmers in northern Thailand, which was Thaksin's political base. Because temperate products are easier to preserve than tropical products, Chinese products can travel far southward to major markets of

\footnotetext{
${ }^{25}$ Interview with a trade official, Beijing, March 2006.

${ }^{26}$ Indonesia's request list already agreed with China included coffee, palm oil, coconut oil, vegetable oil and fats, cocoa powder, soap, vulcanized rubber, glass for cathode-ray tubes and furniture wood. Thailand's list included fruits and vegetables agreed, anthracite and coke of coal. The Philippines's list included microelectronics and motor vehicle parts, which are its main exports to China and on the whole generate a trade surplus despite deficit in agricultural trade. It was also one of China's biggest suppliers of tropical fruits like banana, coconut oil. It also hoped to get more market access in China for its semiconductors, copper cathodes, and other electrical parts.
} 
Thailand. Thai scholars and NGOs have complained about the adverse effects of the CAFTA on small farmers in Thailand and the less developed ASEAN countries, and cast doubt on China's claimed intention of benefiting its partners. Chinese MOFCOM officials insisted that cheaper goods were to the benefit of Thai consumers, as Thai tropical fruits for Chinese consumers, and some Chinese exports (such as garlic) had not reached the quota yet. ${ }^{27}$ Under domestic pressure, the Thai Agricultural Minister went to Beijing in June 2003 to discuss how to make policy adjustments on both sides to reap the benefits and reduce the costs. Measures agreed by the two countries include agricultural cooperation programs and mechanisms to facilitate Thai exports to China.

The EHP had negative impacts not only on ASEAN producers, but also on Chinese domestic producers. As discussed in Chapter 3, Chinese policymakers realized that Chinese land-intensive and tropical products could not compete with ASEAN ones, but they thought the impact would not be much more than that caused by the WTO. In fact, the increase of imported tropical agricultural products from ASEAN because of the EHP has caused significant adverse impacts on some Chinese agricultural producers. Because of limited storage and transportation conditions, most of ASEAN's tropical products cannot travel far to North China. The city of Wuhan in Central China had been the farthest major city they could be transported to by land in the first two years of implementation since 1 January 2004. The sudden increase of tropical products in the markets of provinces bordering ASEAN caused their local prices to drop significantly. Moreover, Chinese domestic producers cannot sell them at high seasonal prices anymore because ASEAN countries produce those products all year long.

Concerned Chinese government agencies, including the Ministry of Agriculture and the local government of Guangxi Province, submitted internal reports to MOFCOM regarding the negative effects. ${ }^{28}$ The MOFCOM responded that they should look at the big picture and consider national interests. In the view of trade policymakers, first, China should 'calculate the total balance sheet' of trade instead of focusing on the costs in only agriculture because the FTA would eliminate tariffs across all sectors; MOFCOM was confident that China would gain

\footnotetext{
${ }^{27}$ Interview with a trade official, Beijing, March 2006.

${ }^{28}$ Interviews with officials at the MOA and the Bureau of Commerce of Guangxi, May 2006.
} 
overall, particularly from manufactured exports. The export of temperate produce might also surpass the import of ASEAN's tropical produce. Second, ASEAN products would not have much impact on the Chinese economy because China had a huge domestic market and ASEAN collectively was a small economy with limited production capabilities. ${ }^{29}$

Some Chinese farmers had to bear the costs of the FTA. They had to stop growing some tropical products at a substantial cost and either switch to other products or go to cities as migrant workers for their livelihood. The reform-minded leadership, Zhu Rongji in particular, believed China's economic development was not sustainable if it kept 70 percent of the Chinese population in agriculture. Therefore, a large portion of that population had to move to "the third industries' - services. That may be directed by government-sponsored programs but most dislocated farmers have become 'illegal' migrant workers in cities, who do not have a legitimate identity card to live or work in the cities under the Chinese residential management system. The government closed one eye to these illegal migrant workers because this migration was believed to be necessary for China's industrialization, as well as to avoid a huge burden of administrative costs. ${ }^{30}$ Such unmanaged dislocation of farmers has caused many social problems in both urban and rural areas in China, which is one reason that the Hu-Wen leadership is more cautious with agricultural liberalisation, as will be discussed in the case of Australia-China FTA.

Farmers do not have an independent collective political voice in China. As Chinese policymakers and academics observed, strong lobbying power in China was in the hands of big state-owned enterprises (SOEs), mostly in heavy industries, resources and key services sectors, whose bosses were also members of the Central Commissions of the Party. In contrast, farmers are scattered geographically and economically. Agricultural production has been organised largely on a family basis instead of on a corporate scale. An independent farmers' union or labour union is not allowed by the Communist Party. There is no national business association for tropical fruits and vegetables. Other business associations in agriculture work mainly with companies - food processors and trade companies, providing information, helping with international lawsuits and facilitating government-business connections. Sub-national business

\footnotetext{
${ }^{29}$ Interview with trade and agricultural officials, 2006 and 2007.

${ }^{30}$ Interview with scholars in Canberra and Beijing, November 2006 and April 2007.
} 
associations do not have much influence on government policymaking, but only provide information to companies to facilitate business. The trade policymakers believed that Chinese farmers had lived on self-sufficiency for so long that they had become resilient to changes in the policy and economic environment; that they usually would not protest, unless they lost the means of livelihood. ${ }^{31}$

Some Chinese scholars comment that the Ministry of Agriculture does not represent the interests of farmers because the promotion of officials depends on their superiors - the Organization Department of the Party, the recommendation of their bosses, and in the case of the Agricultural Minister, by the Prime Minister. The officials at MOA want the agricultural sector to make profits so that they gain credits of work performance, as well as more rents to utilize. They may criticize the policies of equal-level government institutions such as MOFCOM, but if the debate reaches the State Council, they will follow the decision of the State Council without dissent. ${ }^{32}$ That is similar with provincial officials. Moreover, the initial stage of policymaking of the CAFTA before the Framework Agreement was led by the Ministry of Foreign Affairs, which was in a sense in a stronger position to coordinate policy than the MOFTEC vis-à-vis MOA because the MFA represented the strategic preference of the leadership. In the case of the CAFTA, the leadership's determination was clear enough to the MOA officials and local governments that they would not make themselves a hurdle in the policymaking process.

Moreover, Chinese trade policymakers insisted that liberalizing the agricultural industry would be beneficial for improving its productivity and competitiveness. The WTO negotiations were cited as a precedent. When the WTO accession was under negotiation, the agricultural sector expressed severe concern over possible impacts. In response, the Chinese government said that it could only protect the agricultural sector as much as possible, but would firmly proceed with the WTO accession. The trade policymakers held that during the process of entering the WTO, Chinese agriculture developed in the level of technology and

\footnotetext{
${ }^{31}$ Interview with trade officials, March and May 2007. As will be discussed later, the increasing amount of rural unrest in the past several years has alerted the Chinese government to pay more attention to the 'san nong' [three agricultural] issues - farmers, rural areas, and agriculture. It was one of the major focuses of the government's $11^{\text {th }}$ Five-Year Plan of National Economic and Social Development set in 2006.

${ }^{32}$ Interview with scholars working on Chinese agriculture, Beijing, March and April 2006.
} 
industrialization under government guidance and market competition. As will be discussed in the case of Australia-China FTA, this view has changed and led to a different position in the FTA negotiations with Australia.

Manufactured goods, in which China had an advantage, were not included in the Early Harvest Program. Did those sectors in China object to such exclusion? Because FTAs were new to China and their traditional markets had been the US, Japan and Europe, most Chinese manufacturers were not sure of the potential benefits of or particularly enthusiastic about the CAFTA. In fact, most of them were not even aware of the negotiation process or the Agreement at all. A survey conducted by the China-ASEAN Business Association in 2003 showed that 97 percent of Chinese companies did not know of the existence of the CAFTA, or the meaning of FTAs. ${ }^{33}$ As a result, Chinese manufactures did not push the government to open ASEAN markets. They held a 'wait-and-see' attitude.

As some trade officials and academics proudly comment, the Early Harvest Program was an 'innovation', 'a whole new preferential trade arrangement' by China. ${ }^{34}$ By 'keeping politics at the centre' and 'calculating the total balance sheet' of China's interests, the Chinese central policymakers achieved their aim of increasing ASEAN's confidence in the benefits and plausibility of the CAFTA, showed China's generosity and sincerity to ASEAN, and championed China's strategic friends, though at the cost of some Chinese domestic groups.

\section{Wider domestic consultations and the Agreement on Goods}

The realization of the FTA continued to be strongly supported by China's fourthgeneration leadership of Hu and Wen, who came into office in November 2002. Apart from the strategic and political considerations mentioned previously, Chinese scholars believe that the fourth-generation leadership was committed to the realization of the CAFTA to establish their own diplomatic landmark - Deng Xiaoping normalized Sino-US relations and Jiang Zemin improved Sino-Russia relations. The friendship between ASEAN and China was one initiative of Hu Jintao when he was Vice President of the State, before Zhu proposed the FTA to ASEAN.

\footnotetext{
${ }^{33}$ Interview with trade officials and the Director of the China-ASEAN Business Association, March and April 2006.

${ }^{34}$ Shang, Early Harvest Program.
} 
Therefore China propelled the realization of the CAFTA, changing it from a largely political and symbolic partnership to a substantial free trade agreement.

MOFTEC only played a supportive role to MFA before the Framework Agreement was signed. After that, the policymaking power was designated to MOFTEC (MOFCOM from March 2003), the Department of International Cooperation to be specific, to 'carry out' the agreement, as the trade officials referred to it, which actually meant formal negotiations of the terms of the agreement. ${ }^{35}$ In China's later FTA policies, Chinese officials do not see negotiations as 'carrying out' the agreement any more because they learned the more important part was deciding the content of the FTAs.

Led by the MOFCOM, the Chinese negotiators showed more interest in obtaining market access to ASEAN than had been displayed at the previous stage when negotiations had been led by MFA. During the negotiations of the CAFTA, MOFCOM sought opinions from various domestic actors through working meetings, internal reports and phone calls, and organized working meetings of selected participants as it judged 'necessary'. The invitation was not through open channels such as the media or the internet. The Chinese media have only given sporadic reports on what has been achieved between the Chinese and ASEAN governments. According to trade officials, the participants included representatives of major industrial sectors related to the CAFTA - ministries or national business associations - and functional government institutions.

The Ministry of Agriculture - the Department of International Cooperation to be specific - was invited to participate in policymaking in October $2003 .{ }^{36}$ According to the Ministry of Agriculture, farmers at rubber plantations in Hainan province suffered from the import of good-quality and cheap Southeast Asian rubber. However, MOFCOM believed because of the current and potential vast demand of the automobile industry in China, demand for rubber exceeded supply. As to the increase of palm oil imports, because Chinese do not have the habit of using palm oil for cooking, it was mainly imported as an industrial input or for food processing. The cheap price therefore was good for Chinese companies to reduce their

\footnotetext{
${ }^{35}$ Interviews with trade officials in Beijing, 2004 and 2006.

${ }^{36}$ Interviews with a MOA official, Beijing, May 2006.
} 
production costs. However, because the Ministry of Agriculture was involved in negotiations, and the MOFCOM was more concerned with economic interests than the MFA, China did not voluntarily open agricultural sectors to ASEAN for foreign policy objectives, but adopted a more protective stance. As a result, China listed sugar, palm oils, rice, and rubber and some other agricultural products as sensitive products for slower tariff reduction in the Agreement on Trade in Goods. ${ }^{37}$

Local governments were not involved in making policies on the CAFTA, "because that was state policymaking' according to MOFCOM ${ }^{38}$ Local governments were supposed to implement policies set by the central government, or to revise local regulations if inconsistent with the central policies. They could report problems or seek the support of industrial ministries if problems occurred, but they were not invited to the policymaking working meetings organized by the MOFCOM.

At the working meetings organized by MOFCOM, the opinions from industrial representatives were sometimes quite frank. ${ }^{39}$ However, they would usually avoid open policy debate at the meetings, particularly when more than one sector was present. The MOFCOM would listen to them, and take their opinions into consideration when they made policies after the meetings. It does not necessarily mean the opinions of the industries would be reflected in the policy decisions; nor does it mean the policymaking process was systematic. Because China was in a period of economic transition and learning about regional economic cooperation, when conflicts of policy preferences among domestic actors occurred, the decision was quickly left to the State Council or the leadership. It was obvious in the case of the CAFTA that the leadership was eager to realize the FTA with ASEAN. Domestic dissent was therefore kept internal and solved quickly. In public, various domestic sectors followed the lead of the MFA and MOFCOM in carrying out the CAFTA in a cooperative manner.

However, when Chinese domestic producers became more aware of their stakes in the CAFTA, they became more assertive of their interests to MOFCOM. As a MOFCOM official

\footnotetext{
${ }^{37}$ A complete list of China's sensitive list is available on MOFCOM's website at: http://gjs.mofcom.gov.cn/aarticle/af/ah/200804/20080405471634.html.

${ }^{38}$ Interview with a MOFCOM official, Beijing, March 2006.

${ }^{39}$ Interviews in 2004 and 2006.
} 
acknowledged, there were sometimes coordination problems when conflicts of interest appeared. For instance, the raw materials for textile production may be the final products of petroleum. Textile producers would welcome cheaper raw materials but petroleum producers would oppose reducing tariffs on those raw materials. In such situations, the leading negotiators would come up with a solution of both benefits and costs for each sector and ask if the relevant sectors would accept it as the bottom line for negotiation. That is because in one industry, there were usually both sectors that would benefit and sectors that would lose from the FTA. The concession on some sectors would be a condition for the industry to get advantageous conditions in other profitable sectors. Often the negotiators would try to attend more to the interests of raw material producers who would be losers than to the interests of users of raw materials, because they thought the negative effects would have a more severe impact and be more significant than the reduction of potential profits to downstream users. ${ }^{40}$ Moreover, some producers of raw materials are big state-owned enterprises, which are said to be the most influential companies on the central government in China.

If neither domestic sector would concede, the decision would have to be left to higher levels of the policymaking structure such as the MOFCOM Minister or the State Council. Because the leadership was committed to the CAFTA, the coordination process was relatively smooth. Two principles stood overarching: first, sectoral interests could be sacrificed if they were in conflict with the national interest; second, the sectors should try to enhance their competitiveness if they were affected.

As a result of the wider domestic consultation conducted by MOFCOM and its better trade negotiation skills, the Agreement on Trade in Goods signed on 29 November 2004 in Vientiane, Laos, reflected much more the economic interests of China than did the Early Harvest Program. Not only were some sensitive agricultural goods exempted from tariff reduction, but also ASEAN's markets were opened to many manufactured goods from China. To be sure, a number of manufactured products were exempted from tariff reduction by ASEAN countries, because the most important motivation of Beijing behind the CAFTA was still to gain political friendship from ASEAN, and the two parties were sympathetic to each other's status as

\footnotetext{
${ }^{40}$ Interview with a trade official, March 2006.
} 
developing countries (except Singapore). But as will be discussed in the next section, China's export of manufactured goods to ASEAN has increased significantly since the implementation of the CAFTA, a problem that China was forced to address.

Although the recognition of China as a full market economy was not a precondition for China to start formal negotiations with ASEAN for reasons mentioned earlier, China had discovered this 'utility' of FTAs from its engagement with New Zealand and Australia by early 2004. In the FTA on Trade in Goods, ASEAN countries recognized China as a market economy, and gave up the right to apply Sections 15 and 16 of the Protocol of China's accession into the WTO. These provisions stipulate price comparability in determining subsidies and dumping, and provide for a Transitional Product-Specific Safeguard Mechanism, and were regarded by Beijing as one of the major sources of disadvantage for export expansion of China as an economy in transition at the WTO for 15 years. ASEAN members also gave up the right to apply those rights with respect to textiles and clothing. Meanwhile, ASEAN countries retain the rights of anti-dumping, safeguards and countervailing measures at the WTO. They can choose whether to solve trade disputes at the regional or global forum, but as mentioned before, Chinese policymakers expected them to do so through the regional channel. An agreement providing for dispute settlement mechanisms was also signed in November 2004 after bilateral negotiations. Reflecting 'Asian values', coordination and mediation are compulsory before any party decides to go to arbitration. Moreover, the dispute settlement mechanism does not have a permanent body for arbitration; an ad hoc panel of three judges would be formed when necessary, two of whom will be chosen by the complaining and defendant countries respectively. In short, compared with the processes of initiation, feasibility study and the negotiation on the Framework Agreement (including the Early harvest Program), China's policymaking on the CAFTA during the negotiation on trade in goods became more responsive to domestic economic interests. A major reason is the change in the leading agency from MFA to MOFCOM, the latter being more concerned with economic benefits for China and less insulated from domestic interests. One way of involving domestic interests was to invite them to ad hoc working meetings organised by MOFCOM for domestic coordination, which was to become a regular policymaking mechanism in China's future FTAs. The political leadership still played a 
decisive role in facilitating domestic coordination and propelling international negotiations - it was a major reason for the swift process of the CAFTA negotiations.

\section{Dealing with unsatisfactory results}

Since the Early Harvest Program and the Agreement on Trade in Goods came into force in January 2004 and July 2005 respectively, some domestic interests in both China (notably Chinese agriculture and southern provinces) and ASEAN countries have been adversely affected. As a response to the costs, Chinese central policymakers -- in particular the MOFCOM-- have come up with various compensations and solutions outside the FTA to assuage domestic actors on the one hand, and to appease ASEAN on the other.

\subsection{Agriculture}

In 2005, the Agricultural Ministry showed fact sheets to MOFCOM indicating that the prices of tropical fruits such as lychees, longans and bananas plummeted and caused problems for Chinese producers in the southern provinces including Guangxi, Yunnan and Hainan.

MOFCOM sent a mission to those places for market research, and upon its return, argued that ASEAN was only partially responsible for the reduction in the price of longans because it had only $1 / 3$ of the market. The market shares of ASEAN's other products in China were quite small. The price of imported longans, such as those from Thailand, was actually three to four times that of the domestic ones. The price reduction in 2005 was mainly because of change in supply and demand. The longan is a plant of high harvest one year and low the next year, and 2005 was high. Besides, because the domestic fruit market had been over-supplied with other produce like apples and pears, the provincial government of Guangxi encouraged the production of longans in the 1990 s, most of which came into fruition in 2005. Longans piled up in a few markets also because its production in China was scattered in small orchards where transportation conditions or the harvesting techniques were not advanced. As a result, they could not sell far to inland China in large quantities. The MOFCOM held that there was not much an FTA or trade protection could do. 
MOFCOM pointed out that a good effect of those increased imports was that local agricultural sectors started to promote scaled or corporate production to enhance their competitiveness. Some agricultural companies invested in the neighbouring countries for seeds and better natural environments. Some companies imported ASEAN species to grow in China. MOFCOM also argued that more supply and cheaper prices of tropical fruits in northern cities were beneficial to customers.

The increase of scale in fruit plantation was difficult for small farmers, however, because the larger the scale, the more costs in labour, fertilizer, and management etc. ${ }^{41}$ In view of their difficulties, local governments now encourage farmers to change products to the ones they have comparative advantage in, such as oranges, grapefruit, mushrooms, and garlic. However, government subsidy for this adjustment has been little, only in the form of technological support if any.

Some ASEAN countries have complained that the slow procedures at the Chinese customs caused their produce to degrade while waiting to enter the border. Therefore, some ASEAN countries have approached the municipal government of Wuhan in Hubei province in Central China, to discuss the possibility of establishing a direct customs point there so that the products can enter directly into Central China, and be packed there for further sells to Northern China. It would certainly be a boost to Wuhan's economy, and therefore the local government was very enthusiastic about this proposal. However, this proposal has not been approved by the central government. ASEAN countries have also complained about the impact of increased Chinese temperate agricultural produce on local producers. ${ }^{42}$ However, China has not taken any measure to curb their export because they benefit Chinese farmers. Therefore tension remains between the intention of the MFA and the leadership to win ASEAN's political support and the desire of MOFCOM to boost trade.

\footnotetext{
${ }^{41}$ Interview with a Chinese agricultural economist, Beijing, March 2006.

${ }^{42}$ Natividad Y. Bernardino, "The ASEAN-China Free Trade Area: Issues and Prospects," Asia Pacific Network on Food Sovereignty Regional Workshop Papers (6-9 November 2004). Thitapha Wattanapruttipaisan, "ASEAN-China Free Trade Area: Advantages, Challenges, and Implications for the Newer ASEAN Member Countries," ASEAN Economic Bulletin 20, no. 1 (April 2003). Kingkorn Narintarakul, "Thai-China Free Trade Agreement for Whose Benefit?" Asia Pacific Network on Food Sovereignty Regional Workshop Papers (6-9 November 2004). Oxfam, "South-South Tensions: The Case of the ASEAN-China Free Trade Area" (paper presented at the Grantmakers Without Borders Conference, Miami, October 2004).
} 


\subsection{Manufacturing}

A prominent problem after the Agreement on Trade in Goods came into effect was that most Chinese companies did not know how to utilize preferential tariff treatments under the FTA, which reduced the benefits that the tariff reductions should have brought to China.

Because of the effort of MOFCOM, local governments and business associations, Chinese companies have slowly started to discover the market opportunities and preferential tariff rates brought by the FTA. The China-ASEAN Business Association in China has become very active in providing information and facilitating business between Chinese and ASEAN companies. It is a major societal proponent in China for the CAFTA as well as a liaison between the government and businesses. Other business associations, such as the Business Association of Agricultural Machinery and the Business Association of Iron and Steel, have also become active in facilitating exports to ASEAN.

The China-ASEAN Business Association and economists have noted that intra-industry trade has increased significantly between China and ASEAN since the enforcement of the CAFTA, changing the economic structure of the region. China and ASEAN had largely been competitors in third country markets, but with the enforcement of the CAFTA, ASEAN countries have increasingly exported raw materials, manufactured parts and industrial inputs to China, where they are processed and assembled before being exported to third countries (mainly the US and the Europe). The Director of the China-ASEAN Business Association was worried that there was a risk to both ASEAN and China that the products were too concentrated in electronics, and the market was over-dependent on the US. ${ }^{43}$ However, MOFCOM was glad to see that ASEAN's economic dependence on the US, Europe and Japan was gradually being shifted to China so that they were 'bound' with China. ${ }^{44}$ Besides, the business with ASEAN has

\footnotetext{
${ }^{43}$ Interview with the Director of the China-ASEAN Business Association, Beijing, 2006. Also see John Ravenhill, "Is China an Economic Threat to Southeast Asia?" Asian Survey 46, no. 5 (Sep./Oct. 2006). Shaun Breslin, "Power and Production: Rethinking China's Global Economic Role," Review of International Studies 31 (2005), Dieter Ernst, "Global Production Networks in East Asia's Electronics Industry and Upgrading: Perspectives in Malaysia," East-West Center (Honolulu) Working Papers, Economics Series 44 (May 2002). Guillaume Gaulier, Francoise Lemoine, and Deniz Unal-Kesenci, "China's Integration in Asian Production Networks and Its Implications" (paper presented at the Conference on Resolving New Global and Regional Imbalances in an Era of Asian Integration, Tokyo: Research Institute of Economy, Trade, and Industry [RIETI], 2004). Premachandra Athukorala, "Product Fragmentation and Trade Patterns in East Asia," Asian Economic Papers 4, no. 3 (October 2005).

${ }^{44}$ Interview with a trade official, Beijing, March 2006.
} 
been regarded beneficial for promoting export of small and medium-sized Chinese domestic companies, which was less competitive in the domestic market compared to state monopolies and foreign invested companies.

China meant to help the least developed countries (Cambodia, Myanmar, Laos and Vietnam) in ASEAN through increasing imports from them under the FTA, but the trade deficits of those countries have increased because of the increase in China's manufactured exports after the implementation of the treaty. To show Beijing's concern for those least developed countries, China unilaterally reduced more tariffs for those countries. The Chinese government has also come up with policies to encourage Chinese companies to invest in ASEAN, such as providing favourable conditions for loans. Although still limited, some Chinese companies have started investing in ASEAN for their cheap labour, resources or access to other markets, instead of only infrastructure construction in the past. For instance, Cambodia has become a popular destination for Chinese investment because as an LDC, Cambodia enjoys special tariff treatments from developed countries that China does not enjoy, and they can escape the trade restrictions some countries applied to China. The behaviour of Chinese companies in ASEAN countries have sometimes caused locals to be concerned about forgery and bribery, but MOFCOM officials admitted that it was very difficult for them to control the behaviour of overseas companies unless they violated Chinese domestic law.

\subsection{Provinces}

The CAFTA has mostly affected the economy of provinces like Yunnan and Guangxi which produce tropical agricultural products. The provinces therefore decided to 'encourage' (expand and strengthen) the industries with comparative advantage (such as temperate produce and manufacturing), and to 'discourage' (reduce or shrink) those with comparative disadvantage with ASEAN, including tropical plants, fruits, rubber, sugar, synthetic fibres and fertilizers. ${ }^{45}$

The CAFTA has also provided the local governments with opportunities to engage in activities alongside the FTA beyond what they used to be able to do. Because Yunnan and Guangxi were 'sacrificed' in the Early Harvest Program, the central government compensated

\footnotetext{
${ }^{45}$ Shilu Wang, ed., 2005-2006 Dongnan Ya Baogao [Southeast Asia Report 2005-2006], Yunnan Blue Books (Kunming: Yunnan University Press, 2006).
} 
Yunnan with a Kunming-Myanmar road and hydropower stations, and Guangxi with the ChinaASEAN Trade Expo. The background to these two policies was that the central government has been stating that the CAFTA would bring economic opportunities to enliven the economy of West China. Local Chinese officials understood that such opportunities would usually include the support of the central government for their economic development with special policies. In fact, Yunnan and Guangxi have competed to request the central government to champion them in expanding economic relations with ASEAN under the CAFTA. Both provinces are trying to propagate itself as the best location for doing businesses between China and ASEAN. Guangxi aimed to be the axis of "one axis, two wings" (referring to the Pan-Beibu Gulf and Great Mekong Sub-region as two plates and Nanning-Singapore economic corridor as an axis, which forms the shape of the letter $\mathrm{M}$ ) and requested the central government to make it the experimental area of the CAFTA. ${ }^{46}$ At the same time, Yunnan hoped to be the 'dragon's head' of the Great Mekong Sub-region and the centre of a Great M transportation network between China and ASEAN. ${ }^{47}$

The idea of holding the China-ASEAN Expo in China was actually proposed by Yunnan to the central government. Accepting it as a good idea, the central government decided to give the opportunity to Guangxi instead. It was believed in the two provinces that Guangxi was more successful than Yunnan in 'persuading' the central government that it was a better location - it not only has a land border with ASEAN, but also sea ports. ${ }^{48}$ Others believe that the centre also considered that Guangxi used to be a base for the Communist revolution before 1949, but the economy lagged far behind Guangdong because of the government's preferential policies given to the latter, although the two have similar geographical conditions. Besides, Yunnan had already become the major participant in the Great Mekong Sub-regional development project, supported by the Asian Development Bank and the Chinese government, and it hosted a

\footnotetext{
${ }^{46}$ Xu 2003, p. 218.

${ }^{47}$ Shengda He, Xuehong Wang, and Zhankui Gong, eds., Zhongguo-Dongmeng Ziyou Maoyiqu Jianshe yu Yunnan Mianxiang Dongnanya Kaifang [The Construction of the ASEAN-China Free Trade Area and Yunnan's Opening to Southeast Asia] (Kunming: Yunnan People's Press, 2003). Juntao Ren, "Guangxi's Investment and Financing Measures in 'Two Corridors and One Circle' Cooperation," Around Southeast Asia, no. 5 (2006).

${ }^{48}$ Interviews with former and current trade officials as well as scholars in Yunnan and Guangxi, June 2006.
} 
Kunming Trade Fair every year. ${ }^{49}$ As a result, the China-ASEAN Expo was permanently located in Nanning, the capital city of Guangxi Province. Since the first Expo in October 2005, a 'conference economy' has boomed in Nanning, including the construction of hotels, roads and conference sites and other services. As the Guangxi government hoped, the Expo has brought numerous investments and business contracts from Southeast Asia.

Overall, the discourse and attention in China's southern provinces have been turned to the benefits and opportunities brought about by the CAFTA, mostly for the local governments and companies. Costs and challenges have been underplayed and shouldered by farmers. The competition between Yunnan and Guangxi provinces for preferential policies, or the exemplary locality to promote China-ASEAN economic cooperation, has made it even harder for local governments to complain about costs.

As the above section shows, although the Chinese leadership hoped to strengthen the political relationship with ASEAN by granting the latter preferential tariffs, the effect has been mixed: on the one hand, China's imports of ASEAN tropical produce and industrial inputs have increased; on the other hand, the impact of Chinese exports on ASEAN temperate farmers and manufacturers has cast doubt on China's goodwill. This was partly caused by the tension between the pure pursuit of political objectives of the MFA and a more pragmatic stance of MOFCOM, which attends more to domestic economic interests. It also reflected a lack of experience both in China and ASEAN with FTAs when they embarked on this originally symbolic journey. At the same time, some Chinese tropical farmers have suffered from the increased imports from ASEAN but have received little compensation. The ignorance of their costs was caused by a combination of reasons: the strong political commitment of the leadership and MFA, and hence the reservation of MOA and local governments to express dissent; the lack of a farmers' union; the liberal economic view of MOFCOM; and the competition among local governments for special policies from Beijing to boost their economic development in the pretext of strengthening Sino-ASEAN economic relations.

\footnotetext{
${ }^{49}$ Interview with a trade official, April 2007, a scholar at CASS, Beijing, March 2006 and scholars in Kunming in June 2006.
} 


\section{Negotiations on services and investment}

By mutual agreement, China and ASEAN did not conduct negotiations on services and investment before the accomplishment of the Agreement on Goods because they were too sensitive and complicated for both parties then. At the same time, because ASEAN was the most important target of China's regional economic diplomacy, Chinese policymakers were determined to make ASEAN its first partner in an FTA in services and investment as well. ${ }^{50}$ Despite the strong political will, the negotiation process has been slower than that on trade in goods, because both sides were constrained by their levels of economic development. China had opened the service sector to Hong Kong and Macau, but they were part of the plan to integrate the economies with the mainland in order to ensure political integration. Although China has been opening the service sectors, in particular as required by the WTO, banking, transportation and telecommunication are still under tight state control or administrative monopoly, and ministries in charge of these sectors were powerful actors in the central government. Most ASEAN countries are developing countries and are cautious in liberalizing their services sector as well. Because of political pressure on the trade negotiators to achieve something in this sector, ${ }^{51}$ two years after the Agreement on Trade in Goods, China and ASEAN signed the Agreement on Trade in Services on 14 January 2007 following the $10^{\text {th }}$ ASEAN-China Summit, which entered into force in July 2007. According to the plan of China and ASEAN, it was only the first of the three rounds of services agreements which was to be completed by 2010 , the deadline for China and more developed ASEAN countries to establish a free trade area. As the first FTA in services for both China and ASEAN, the content of the agreement is rather limited —including only computer, real estate, environment, some business services and limited transport services. Notably absent from coverage are financial and telecommunication services. ${ }^{52}$ Because China's offers were part of its package for the new round of WTO negotiations, ASEAN thought it should take the opportunity provided by the FTA for earlier

\footnotetext{
${ }^{50}$ Interviews with MOFCOM officials, 2006 and 2007.

${ }^{51}$ Interview with a MOFCOM official, Beijing, April 2007.

${ }^{52}$ China signed FTA in services with Chile on 13 April 2008, also covering limited areas for liberalisation including computer, management consulting, mineral exploration, environment, sporting and air transport services. China's commitments in the FTA with New Zealand signed on 7 April 2008 cover similar services sectors with additional commitments in education.
} 
market access. Chinese trade officials held that this selective, gradual approach accommodated the different development levels of the countries.

As a country with most of its comparative advantage in services and a higher level of development than other ASEAN countries, Singapore proposed a bilateral agreement with China because it desired the preferential treatment on services enjoyed by Hong Kong and Macau. In February 2004, a senior MOFCOM official reportedly acknowledged the possibility of setting up an FTA with a single ASEAN member when negotiations for the CAFTA in goods were concluded. ${ }^{53}$ In October 2004, Singapore's Minister for Trade and Industry Lim Hng Kiang expressed hope that talks on an FTA between China and Singapore should start as soon as possible ${ }^{54}$ However, no progress occurred because of political tensions arising from Singaporean Prime Minister Lee Sien Loong's visit to Taiwan in December 2004 until bilateral political relations gradually thawed. In August 2006, the two countries agreed to launch negotiations in October 2006, after the third meeting of the Joint Council for Bilateral Cooperation (JCBC) in Beijing co-chaired by Singapore Deputy Prime Minister Wong Kan Seng and Chinese Vice Premier Wu Yi, who used to be Minister of MOFTEC. Upon her visit to Singapore in July 2007, Wu Yi urged Singaporean businesses to seize opportunities in China, including in the services, energy conservation and environmental protection sectors. ${ }^{55}$ Although Singapore has been advocating that more advanced countries in ASEAN should go ahead with bilateral FTAs with other countries and hopes the FTA would be achieved by 2008, China's principle remained unchanged that no bilateral agreement on services with Singapore should be reached before the accomplishment of a collective one with ASEAN. There was also concern that Singapore is already a free port like Hong Kong and Macau but without the political status of these other territories of being part of China.

It has been difficult to reach consensus in the negotiations on the investment agreement because, according to the Secretary-General of ASEAN Ong Keng Yong, both China and

\footnotetext{
${ }^{53}$ Qide Chen, "China, Singapore Working on Free Trade Deal," China Daily, 1 March 2004.

54 “Interview: China-ASEAN FTA to Help Bring about Asia's Economic Integration", People's Daily Online, 31 Oct. 2004.

55 “Singapore Sees China FTA by Next Year", China Daily, 12 July 2007.
} 
ASEAN were "swimming at the deep end of the pool, helping each other" ${ }^{56}$ Chinese central and local governments in general try to attract foreign capital and technology because foreign direct investment (FDI) has been an important engine of economic growth in the past two decades. Chinese policymakers predicted on the one hand that the investment from ASEAN would not increase significantly because the scale of ASEAN economies was small, they depended heavily on FDI from developed countries, and they were still recovering from the Asian Financial Crisis. On the other hand, because of the geographical and cultural proximities, ASEAN would be the prior market of China's future investments. ${ }^{57}$ Although investing in ASEAN was believed to be helpful for the Chinese enterprises to gain experience in investing overseas, or 'going out', many difficulties still existed. ${ }^{58}$ Companies investing in ASEAN have had problems such as insecure social and political environments, corruption, and lack of transparency in local policies. There has also been malicious competition among Chinese enterprises in ASEAN — such as price wars and poor quality — which has affected the credit of Chinese products. Therefore, at the initial stage of the negotiations on investment, the Chinese government was not as eager as ASEAN countries in pushing forward the Agreement on Investment. However, when foreign capital did not seem to be in shortage anymore compared with advanced technology, domestic market potential and resources, encouraging companies to 'go out' has become an important strategy of the Chinese government. In October 2007, Chinese Vice Premier Zeng Peiyan urged CAFTA negotiators to reach an agreement on investment, saying that ASEAN countries were the major target areas for Chinese enterprises to conduct overseas operations. Apart from natural resources, cheap labour and access to other markets as mentioned earlier, ASEAN countries could also provide space for Chinese companies in 'sunset' industries, so that domestic space could be created for sectors with higher technology. According to Zeng, "China and ASEAN could be strategically important partners as they are culturally similar and economically complementary."

\footnotetext{
${ }^{56}$ Qingfen Ding, "China, ASEAN on Crucial Stage in FTA Talks", China Daily, 1 Nov. 2007.

${ }^{57} \mathrm{Xu} 2003$, p. 84.

${ }^{58}$ Interview with trade officials and scholars, 2006 and 2007.

${ }^{59}$ Qingfen Ding, “Investment Pact Urged with Bloc,” China Daily, 29 Oct. 2007.
} 
The slow negotiations on the CAFTA in services and investment despite strong political commitments from both China and ASEAN demonstrate the constraints of domestic economic conditions on economic diplomacy. In particular, China has become more cautious in giving concessions to ASEAN than it was in commodities because of concerns of economic security and the protectionist stance of some services sectors. The two sides were able to reach a firstphase agreement in services because they both preferred a selective, gradual approach to trade liberalisation. The change in China's attitude towards an investment agreement reflects a shift in development strategy - from dependence on inward FDI and export towards a more balanced strategy that encourages outward investment and industrial upgrading. One thing remains unchanged - the necessity of their being a good political relationship between Beijing and the partner governments for achieving progress in FTA negotiations.

\section{Conclusion: The role of institutions and institutional change in China's CAFTA policymaking}

The theoretical framework in Chapter Two suggested three aspects of institutions may be decisive for policy outcomes: the degree of insulation of the central decision makers from domestic interest groups, the degree of fragmentation of state power, and the degree of collective action of domestic interest groups. Besides these factors, institutional change is also crucial given the 'path dependence' of institutions and its implications for policies. This section will first analyze those three aspects of China's policymaking institutions on the CAFTA and how they have affected decision making. It will be followed by a discussion of the forms and causes of institutional change during China's CAFTA policymaking.

\subsection{Insulation}

The degree of insulation of Chinese central decision makers from domestic interest groups was high initially but decreased during the process of the CAFTA policymaking. At the stage of initiation, the Premier proposed the FTA to ASEAN, without informing the relevant ministries in advance. Then work was quickly organized in a closed circle to follow the leadership's initiative. The MFA was delegated the power to lead the domestic policymaking for the Feasibility Study and negotiations on the Framework Agreement. The Feasibility Study was 
further delegated by the government to a small group of Chinese scholars, who were appointed by and had close relations with the central government. During the Feasibility Study, information and discussion were limited to a few actors - mostly the experts in the group, the MFA and the MOFTEC. There were internal studies at the National Development and Reforms Commission and the Ministry of Agriculture, but they hardly expressed any dissent, either because FTAs were new to them or they understood the strong desire of the leadership to see an agreement successfully concluded.

The leading position of the MFA in the policymaking in China till the Framework Agreement indicated that political considerations carried much weight in China's CAFTA policy - to ease ASEAN's concern of the 'China threat' and to ensure a safe immediate strategic environment for China. It also limited the access of industries or local governments to policymaking because they did not have direct or official channels to gather information from or express concerns to the MFA. The MFA did not seek opinions from domestic industries, local governments or local academics, either through internal or public channels. Because of limited information and channel for 'lobbying', domestic societal actors had little influence on the central government's decisions with regards to the Framework Agreement, including an Early Harvest Program which entailed largely one-sided concessions made by China.

However, the central policymakers were not completely insulated. The leadership was informed by earlier ideas from academics about regionalism. More importantly, the degree of insulation from domestic interests decreased during the policymaking process, when MOFCOM became the lead agency and when more domestic actors became aware of the CAFTA policy and its potential impact on their interests. The China-ASEAN Business Association and local governments helped inform domestic companies of the CAFTA and the related business opportunities. Still, private or societal actors did not have a direct influence on the central policymakers. They had to do so through ministries or local governments. The Ministry of Agriculture has become more vocal in support of their interests, in particular after the Early Harvest Program caused adverse effects on farmers of tropical produce. So, too, were the provincial governments of Yunnan and Guangxi. Moreover, negotiations were led by MOFCOM, which, compared with the MFA, was more concerned with economic benefits for 
China and more accessible by domestic interest groups represented by industrial ministries. Therefore, MOFCOM organized ad hoc working meetings to discuss China's position in the negotiations. These meetings were behind closed doors but more actors were invited to give their opinions, and the meetings have become an important venue for domestic coordination on FTA policies. Although the progress of the negotiations was not made public in the media or available to domestic industries, the MOFCOM had to respond to domestic interests if the latter complained that their interests were or would be compromised, by investigating the claims and/or adjusting their position in negotiations. For instance, it excluded several agricultural products from tariff reduction in the Agreement on Trade in Goods, adopted a cautious approach to negotiations on services and investment, and compensated Yunnan and Guangxi provinces with 'extra-FTA' policies for their losses in agriculture.

\subsection{Fragmentation}

The fragmentation of state power in the CAFTA policymaking was low. FTAs in China do not need the ratification of the legislature - the National People's Congress - to take force. Horizontally, the policymaking responsibility was distributed only between the MFA and MOFTEC/MOFCOM, but with one of the two being in a leading position at each stage. In contrast with the policymaking on the Australia-China FTA (AUCFTA) as will be discussed in the next Chapter, the CAFTA did not need the co-signature [ hui qian] of other state ministries in charge of domestic industries. Vertically, it did not need the support of provincial governments before the Agreement was decided. Therefore, policy coordination within the government was much easier and consensus was reached much faster than during the negotiations for the AUCFTA.

However, the MOFCOM understood that many parts of the Agreement - central government policies in general - needed the cooperation of relevant industries and provinces to be fully implemented, for instance on matters of non-tariff barriers of trade and investment licenses. Because it cared about the real economic effects of the CAFTA, the MOFCOM sought opinions from various actors at later stages of the negotiations, in order to formulate pragmatic positions in the negotiations and to create a positive domestic discourse. As FTAs become more 
and more important in China's foreign economic policy, the central government might intentionally distribute the power more widely so that the decision making is more 'scientific', although it may increase the difficulty of coordination among ministerial interests.

\subsection{Collective action}

Chinese domestic industries had to influence trade policymaking indirectly through the ministries in charge. Farmers and workers did not have an independent collective voice because no such union was allowed in China, production was scattered and they had little information about the policy. As a result, farmers were the biggest losers in the CAFTA.

In one industry, agriculture being the typical example, usually both benefits and costs were expected from the CAFTA, but the officials in charge of the industry were uncertain of the balance sheet, because they often lacked information and research capacity. Besides, officials had career goals, which were determined largely by their superiors; therefore they did not completely represent the interests of their administered sector or region. Local governments could not act collectively to influence the materialization of the FTA either -- even if they shared interests, they competed with each other for the preferential policies from the centre, which have been a prominent feature in China's economic liberalisation. In fact, by championing regions or companies in the process - either by giving financial or policy support, or by citing the successful ones as examples - the government successfully avoided collective objection or ignorance of the policy.

It seemed true that losers (agriculture in this case) had more reaction than winners (manufacturers) to the prospect of the proposed FTA compromising their interests, because loss was certain but manufacturers did not know what benefits or 'opportunity cost' they would have, since they had traditional markets elsewhere. The trade negotiators were also inclined to attend to the interests of up-stream raw material producers than down-stream manufacturers because they thought cost would be more sensitive. This may be proof of the adage that the government often picks losers than winners, because the former has a higher capacity for collective action. 


\subsection{Institutional change in China's FTA policymaking:}

During the policymaking process of the CAFTA, the policymaking institutions developed and changed because the FTA was a new policy area for China, it needed international coordination and learning, and the leading agencies in the policymaking institutions changed.

Because the CAFTA was the first FTA of China, Chinese foreign policy and foreign trade policymakers could arrange special institutions for the policymaking, avoiding traditional problematic or inefficient institutions. The Feasibility Study Group was one such creation to insulate information, limit influence of other actors, direct discourse, and give legitimacy to the policy. Originally the study was only part of a joint China-ASEAN report on bilateral economic relations, but Chinese policymakers have increasingly relied on the results to persuade domestic and international actors of the salience of the FTA policy. The Feasibility Study has also become a common practice before China's FTA negotiations, copying practice in other parts of the world.

Institutional learning played a part in China's policymaking on the CAFTA not only in the usage of the Feasibility Study. As the first of China's FTAs, the CAFTA has borrowed the forms of other FTAs, notably the ASEAN FTA. It was intended as a means to show Beijing's respect for ASEAN's experience in economic integration and its role in the region. During the process of negotiations, Chinese trade policymakers gained knowledge about FTAs and experience in trade negotiation. To coordinate specific policies like customs procedures, quarantine and industrial standards, the two sides have tried to streamline some of their domestic institutions in order to facilitate economic exchange under the FTA.

The working meeting organized by MOFCOM to consult with domestic industries was another mechanism specially developed for the CAFTA, because it was a new policy area that demanded coordination of policies and resources. It gradually become a standardized institution for domestic coordination during China's FTA negotiations. It is similar to the Central Leading Groups organized by the State Council to deal with urgent or crucial matters such as the SARS, the WTO accession, and financial reforms. They gathered opinions and resources while keeping domestic dissent internal among a selected group of participants. However, the central leading groups usually have the participation of a vice Prime Minister or Prime Minister so that 
decisions were quickly made and authoritative. By organizing the working meetings, the MOFCOM used the power that the leadership delegated to it to make the FTA policies and therefore they had a leading position in the coordination mechanism. It was an efficient way of communication among interested domestic actors. The working meetings for CAFTA policymaking have played an effective role in coordinating domestic and national interests as well as conflicts among domestic groups, partly because MOFCOM did not need the consensus of other actors to make decisions on the CAFTA, and partly because domestic actors were clear of the leadership's compelling interest in realising the agreement. However, if the ratification or implementation needs the cooperation of other actors, the MOFCOM would still be only an organizer or coordinator instead of a decision maker. Tough obstacles still need the intervention of a higher level leadership to overcome. Moreover, it is questionable whether such a closed mechanism could provide enough information to the trade negotiators about China's interests in an FTA to make sound judgments.

The change of the leading agency caused obvious institutional change and in turn policy change in China's CAFTA policymaking process. The transition of main responsibility from the MFA to MOFCOM caused the degree of insulation of the central policymakers from domestic groups to decrease, China's emphasis on political interests to be more balanced with economic interests, and the CAFTA to develop from a rather symbolic partnership to a substantial FTA.

It is worth noting that from the CAFTA, Beijing learned that FTAs could be a useful economic instrument to bind countries together politically, in particular if a degree of dependence on the Chinese economy was cultivated in the partner countries. The Chinese policymakers also learned how to use the 'championship strategy' to realize its FTA policieschampion certain sectors as the Early Harvest Program did so that the FTA partner would be willing to negotiate in wider sectors; champion domestic regions such as Guangxi so that other provinces would be more willing to accept economic costs in order to gain equal treatment; and champion certain countries such as Thailand among ASEAN, and ASEAN among all other countries, so that other countries would compete to seek China's FTA partnership. 
In contrast to the China-ASEAN FTA, the progress of negotiations between China and Australia on an FTA has been extremely slow, characterised in particular by China's reluctance to accommodate Australia's requests. Given Beijing's ostensible interests such as acquiring Australian energy and resources, why has China been more protectionist in the FTA negotiations with Australia than with ASEAN, especially on agricultural trade? Is it simply because an agreement with Australia has more potential to cause damage to domestic interests in China? Or is it simply because Beijing did not attach as much strategic importance to Australia as to ASEAN?

Based on the author's interviews with government, private and academic institutions in Beijing (from February to June 2006, and from April to May 2007) and on relevant documents, this chapter provides an explanation by looking into the policymaking process in China. It first provides a brief background of the Australia-China FTA (hereafter, AUCFTA) talks, and then depicts the policymaking process at three stages, namely, the initiation, the Feasibility Study and the formal negotiations. The first stage included the central government's assessment of its national political and economic interests in this FTA. The second stage, the Feasibility Study, was an initial exposition of the differences between the two countries over issues like agriculture and China's Market Economy Status. The formal negotiation process, especially China's stance in it so far, is a clear demonstration of how China's protectionist domestic interests (in particular agriculture and services) and the different approaches between the two countries to FTA negotiation have halted the progress. It highlights the weakness of the Chinese trade policymakers under the current institutional settings in overcoming protectionist domestic forces even though they hope to liberalize trade. This chapter concludes by analyzing China's policymaking on the Australia-China FTA, particularly how institutions have structured the interactions among different policy preferences (including interests and ideas) held by domestic actors, and led some preferences to prevail over others. Following the discussion in Chapter Two, it focuses on three features of institutions - insulation, collective action and fragmentation - to see how they help to explain China's policies on this FTA. Finally, this 
chapter discusses whether institutions indeed resist change, as historical institutionalism argues, and the conditions under which institutions are likely to change and develop.

\section{Background}

Since China and Australia established diplomatic relations in December 1972, bilateral relations have been on friendly terms, and bilateral trade has increased significantly, especially since China's entry into the WTO. During the decade leading up to 2003, China moved from being the tenth to the third largest merchandise export market of Australia, and Australia remained within the top ten of China's trade partners. 'They are both members of APEC and the East Asia Summit (the ASEAN Plus Six Forum); under the last Labour Government, Australia was an early and strong supporter of China's accession to the WTO.

When China started to embark on free trade agreements (FTAs) in international economic cooperation, the first being ASEAN in November 2001, Australia became worried that they would lose the Chinese market to China's FTA partners. The Australian Trade Minister Mark Vaile said that "it is vital that we grasp this opportunity to stay ahead of the pack." ${ }^{2}$ At the same time, Australia was negotiating an FTA with the US, which might produce discrimination against Chinese products and investment in Australia.

After a series of high-level diplomatic visits, upon Chinese President Hu Jintao's visit to Australia in October 2003, China accepted Australia's proposal and the two governments signed the Australia-China Trade and Economic Framework (the Framework Agreement), in which they agreed to look into the feasibility of a bilateral free trade agreement. The Joint Feasibility Study was finished in March 2005, and formal negotiations commenced in April. Although the Feasibility Study was accomplished earlier than the October target, the progress of SinoAustralian free trade talks has been far slower than that between China and other partnersASEAN, Pakistan or Chile - not least because of Australia's insistence on a much more comprehensive agreement than China has negotiated in the past.

\footnotetext{
${ }^{1}$ Australia Bureau of Statistics, Year Book Australia 2003, International Relations: Australia's Bilateral Relations, p. 6. China has become the second largest market after Japan for Australia in 2007.

2 "Australian Firms Raise Concerns over FTA with China," Asia Pulse, 18 August 2005.
} 


\section{Initiation and National Interests}

From the information I gathered from interviews in Beijing, the Australia-China FTA was proposed by the Australian Deputy Secretary of the Australian Department of Foreign Affairs and Trade (DFAT), Geoff Raby, to China during his visit to Beijing in July 2003. Political analyses were first conducted as a preliminary assessment in China by the Ministry of Foreign Affairs (MFA) and the China Institute of Contemporary International Relations (CICIR), a quasi-governmental think tank mainly concerned with state security issues. Based on the following preliminary judgment by the two institutions on China's national political and economic interests in the prospective FTA, China gave Australia a positive response. ${ }^{3}$

\subsection{National Political Interests}

Ministry of Commerce (MOFCOM) officials believe because FTAs are all rooted in political relationships and always have implications for both the diplomatic relationship between the countries and for domestic politics, all FTA negotiations need the commitment of the leadership to be successful. That commitment is generally perceived to originate from foreign policy objectives. After Australia proposed the FTA to China, as usual with every country proposing FTAs, China first conducted a 'political assessment' of bilateral relations.

First, China judged that the political conditions were 'mature' enough. In other words, there was enough political trust between Beijing and Canberra, and they did not have "fundamental differences". Australia was one of the first countries to establish diplomatic relations shortly after Sino-US détente in 1972. It removed its diplomatic office from Taiwan immediately and has always respected the mainland's One China policy. Bilateral relations had since been marked by frequent two-way visits. ${ }^{4}$ Canberra had been trying to develop friendly political relations with Beijing instead of allowing Washington's concerns to dominate its relations with

\footnotetext{
${ }^{3}$ Interview with a researcher at the Department of Policy Research of MFA and a researcher at CICIR, Beijing, April 2006. Also see Jiechi Yang, "Deepen All-Round Cooperation and Promote Common Prosperity, Speech by Vice Minister Yang Jiechi of the Ministry of Foreign Affairs of the People's Republic of China at the Asia Society of Australasia Center in Melbourne " 13 December 2005. ${ }^{4}$ Australian Prime Minister John Howard's meeting with Dalai Lama in June 2007 triggered protest from the Chinese Ministry of Foreign Affairs. It might have affected the negotiation process, which has been stagnant since then. The new Prime Minister Kevin Rudd visited Beijing in April 2008 to rekindle the free trade negotiations amongst other objectives, but again his criticism on the recent situation in Tibet might hinder that objective. One may recall that China postponed the FTA negotiation with Singapore after Lee Hsien Loong visited Taiwan in 2004; the two countries resumed FTA talks in 2006.
} 
Beijing. Beijing appreciated Australia as offering First World goods and services without "the political baggage that comes with the Americans and the Europeans." ${ }^{5}$ Moreover, Beijing was comfortable to be the recipient of Australia's request for an FTA, as it has been in most of China's FTA talks. Since Canberra sought closer relations with China because it was afraid of being disadvantaged by China's other FTA partners in the Chinese market and marginalized from regional affairs of Asia, Beijing believed itself to be in a good position to negotiate favourable terms.

Second, China has tried to expand FTA relations with countries in every continent in order to have strategic friends all over the world, apart from its expansion of markets. China views Australia as an important country in the South Pacific as well as the Southern hemisphere. Because of Australia's leading role in South Pacific affairs, according to the MFA, China has traditionally respected Australia's opinion when it conducts diplomacy there, such as in dealing with the violent incident against ethnic Chinese in the Solomon Islands. ${ }^{6}$ In Beijing's strategic map, Australia belongs to the 'big neighbourhood' and so the 'friendly neighbourhood' policy should apply.

Finally, Beijing regretted that the Sino-Australian bilateral relations were not close enough, which may reflect its concern with Australia's strategic alliance with the US and Japan. At the government level, apart from cultural exchanges, bilateral political and economic cooperation had not been substantial. Although China tried to have 'strategic partnerships' with every major regional power in the world, the Sino-Australia relationship was still one of 'friendly cooperation', which is a label Beijing applies to a more distant relationship. Since economic diplomacy had become a primary national strategy, Beijing learned that FTAs could promote political trust, like the China-ASEAN FTA had done. Zhang Lijun, former director of the Department of North American and Oceania at the Ministry of Foreign Affairs, also believed that the potential FTA would make Sino-Australian ties "more concrete and diversified", signalling a "new phase" in bilateral relations and paving the way to a better

\footnotetext{
${ }^{5}$ Interview with a researcher at CICIR, who participated in the preliminary evaluation, 18 April 2006 , Beijing. Also see Rowan Callick, "A Mutual Attraction," Australian Financial Review 23 August (2004) ${ }^{6}$ Interview with an official at the Chinese Embassy in Australia, Canberra, December 2006.

${ }^{7}$ The small neighbourhood refers to countries adjacent to China, including Southeast and Northeast Asia and other countries bordering China. Interview with CICIR, Beijing, April 2006.
} 
international trading status for China. ${ }^{8}$ In a word, Australia was judged to be 'politically qualified' to become China's FTA partner.

The Australian leadership also gave a lot of political support to the initiative, reiterating the benefits and importance of the prospective FTA to domestic audiences and its Chinese counterpart. Because of the political commitment of the leadership of both countries, trade negotiators were under great pressure to deliver an agreement. According to Chinese negotiators from MOFCOM, they had felt even more pressure from the Chinese leadership than in the case with ASEAN, mostly because of warm political relations represented by frequent bilateral visits. ${ }^{9}$ Premier Wen Jiabao said upon his visit to Australia in April 2006 that he hoped the negotiations could achieve an important breakthrough in the next one or two years. If the Chinese central policymakers have as much autonomy as the conventional wisdom tells, they should have little problem in deciding on the agreement, or imposing concessions on some domestic sectors if necessary. However, as will be discussed later, the weak position of Chinese trade policymakers in coordinating domestic interests, and the different approaches of the two countries to negotiation have significantly impeded the progress. Unless the political leaderships intervene in a significant way in the negotiations (Australian Prime Minister Kevin Rudd's visit to Beijing in April 2008 seemed to provide such an opportunity but the effect remains to be seen as will be discussed later) or the Chinese trade negotiators from MOFCOM are empowered visà-vis other agencies through some institutional change, the progress would continue to be difficult if both countries insist on their initial agenda for negotiation.

\subsection{National Economic Interests}

There were two major economic motivations for China to form an FTA with Australia. The first motivation was that Australia had energy resources and raw materials that China needed for domestic economic development. ${ }^{10}$ Securing a stable supply of resources had

\footnotetext{
8 "Howard likely to grant MES to China", China Daily (North America ed.), 18 Apr. 2005. A researcher at the Institute of Foreign Trade and Economic Cooperation (IFTEC) made a similar comment; see "Talks to Focus on Free Trade Agreement”, China Daily (North America ed.), 23 Feb. 2004.

${ }^{9}$ Interview with a MOFCOM official, Beijing, April 2006.

${ }^{10}$ Uranium is not included in the FTA negotiation agenda. The two countries signed the Australia-China Nuclear Material Transfer Agreement and Nuclear Cooperation Agreement in April 2006 to open Australian uranium sales to China, which was ratified in January 2007.
} 
become a priority in China's foreign economic policy objectives, as well as a crucial part of national security - 'energy security', when the international competition for resources had become an issue of national security for big consumer countries, as well as for the resource-rich supplier countries. Australia had been one of the major suppliers for China's need of minerals like iron ore, nickel and copper, and had abundant natural gas reserves. ${ }^{11}$ A MOFCOM official said that Australia was becoming an increasingly important provider now that Asia alone could not meet China's needs; for instance, Indonesia was turning into an importing country for petroleum.

At the same time, the price hikes of mineral resources by Australian companies since 2003 had caused unease in China about Australian intentions. The Australian government explained that the resources trade was a matter of private company decisions, and not controlled by the state because Australia was a market economy. Chinese officials, however, believed that the Australian government should still have been able to restrain such company behaviours and that the FTA was a way to propel a more stable price mechanism. ${ }^{12}$

Besides, Chinese investments in Australia did not receive the same treatment as American investments because the latter enjoy preferential treatments under the US-Australia FTA. China has signalled that it might try to follow the lead of the US which won major concessions under the Australian Foreign Investment Review Board (FIRB) in its FTA with Australia. ${ }^{13}$ In talks with Chinese leaders in April 2005, the Australian Prime Minister John Howard said that Australia would consider changes to foreign investment guidelines to give China preferential treatment in buying into Australian resource projects under the FTA and that Australia was "highly desirous" of greater Chinese investment in Australian resources. ${ }^{14}$ China's biggest minerals trading company, the state-owned Minmetals (Wu Kuang) Corporation regards Australia as a "trusted, long-term, First World trading partner", targeting resources like

\footnotetext{
${ }^{11} 40 \%$ of China's total import is iron ore, and $20 \%$ of China's imported iron ore comes from Australia.

12 Interviews with MOFCOM officials, Beijing, April 2006.

${ }^{13}$ Under the Australia-US FTA, American investments in Australia are reviewed by the FIRB only if they are above AUD $\$ 800$ million, instead of $\$ 50$ million for those from all other countries.

${ }^{14}$ Catherine Armitage, "Changes Likely to Laws for Investors," The Australian, 20 April 2005.
} 
iron ore, copper, bauxite, nickel, lead and zinc, but it also hopes some restrictions to China's investment in Australia and the tariff on mineral products can be removed through the FTA. ${ }^{15}$

The linkage that Beijing has attached between energy supply and the FTA has been quite ostensible. During Hu's visit in October 2003, on the sideline of the Framework agreement, the two countries signed a US $\$ 30$ billion deal to supply 3.3 million tonnes of Australian liquefied natural gas (LNG) over 25 years. In July 2006 the Australian Prime Minister John Howard and Chinese Premier Wen Jiabao met in Shenzhen to inaugurate a gas terminal where Australian LNG worth AUD \$25 million would be processed. It is said that China was choosing between Indonesia and Australia for the supplier of this project, and John Howard reportedly lobbied hard for the agreement. ${ }^{16}$ In his speech at the ceremony, Wen expected the two countries to make active efforts to push forward the FTA negotiations, and to strive to reach a high quality agreement beneficial to both sides as soon as possible. ${ }^{17}$

The second motivation of Beijing to enter into FTA negotiations with Canberra was to ask for market economy status from Australia and subsequently use this to request the EU and the US to follow suit, which would ease the disadvantaged position of China as an economy in transition for 15 years in anti-dumping cases under the WTO. ${ }^{18}$ Since China's entry into the WTO, it has faced numerous anti-dumping measures and investigations, and feels greatly disadvantaged because of its status as an economy in transition. China hopes to redress this problem by seeking market economy status from individual countries. ${ }^{19}$ By April 2008 China had obtained it from 77 countries, including its current or potential FTA partners like ASEAN, South Korea, New Zealand, Australia, Iceland, Pakistan, and South Africa. Recognition of China as a market economy has become a non-negotiable precondition of China to start formal

\footnotetext{
${ }^{15}$ Yufang Song, "Speech at the Australia-China Free Trade Conference" (Shenzhen, 28-29 June 2006).

${ }^{16}$ Interview with a MOFCOM official, Beijing April 2006. Reuters, "Howard Trade Trip Signals Closer Ties," The Standard, 27 June 2006.

${ }^{17}$ China MFA, "Premier Wen Jiabao Holds Talks with Australian Prime Minister John Howard," 28 June 2006 http://www.fmprc.gov.cn/eng/zxxx/t260999.htm.

${ }^{18}$ A total of 57 countries have accepted China's status as a market economy since New Zealand stood out as the first acceptor in April 2004, including Australia, Brazil, South Africa and Russia.

${ }^{19}$ For discussions in China on this issue, see Shichun Wang and Ye Quanliang, "Non-Market Economy Status: Anti-Dumping and Countermeasures," Finance and Trade Economics, no. 5 (2005); Rui Zhang, "Anti-Dumping: Developing Countries 'Targeting' China," High-Tech (October 2005). Hong Song, "NonMarket Economy Status and the Development of China's Foreign Trade," World Economy and Politics, no. 10 2004). Also see Owen Brown, "Long March for Australia, China FTA," Down Jones Newswires, 20 April 2005.
} 
FTA negotiations. When explaining China's agreement to New Zealand's and Iceland's proposals for FTAs with China, Beijing stressed that they were the first country and the first in Europe respectively to acknowledge China as a market economy. ${ }^{20}$ As will be discussed later, China did not agree to start FTA negotiations with Australia until the latter granted China Market Economy Status in April 2005. China also hopes the recognition by some developed countries of China as a market economy would set a precedent and propel other major WTO members like the US and EU to follow suit (because they would then be in a weaker position to oppose the other market economies' assessment that China is a market economy). A former leader of Australia's Liberal Party, John Hewson, said that obtaining the market economy status was so primary in China's motivation to negotiate the FTA with Australia that after obtaining the market economy status, the Chinese might "back off" from negotiations and "it'll look like they have used us to get market economy recognition". ${ }^{21}$

Apart from the reasons of energy supply and the market economy status, the CICIR prioritised the FTA negotiation with Australia over that with New Zealand, although the latter had first proposed an agreement, because it thought that China and Australia had a much bigger volume of trade and "highly complementary" economic structures and therefore would bring greater economic benefits to China, especially for Chinese manufactured exports and resources imports. ${ }^{22}$ However, China achieved the FTA with New Zealand first, because the latter has a smaller economy than Australia and did not insist on a comprehensive deal as Australia does, as will be discussed in detail later. ${ }^{23}$

During Chinese President Hu Jintao's visit to Australia in October 2003, the trade ministers representing two governments signed the Framework Agreement as a foundation for closer bilateral economic and trade relations. They agreed to conduct a joint study into the "feasibility and benefits" of an Australia-China FTA within two years. However, no time frame

\footnotetext{
${ }^{20}$ MOFCOM, "Yu Jianhua talks." Jize Qin, "New Zealand Set to Hit Another 1st with China," China Daily (North American ed.), 11 June 2005.

${ }^{21}$ Questions Raised over Benefit to Australia of Trade Deal with China (ABC Radio Australia, 29 April 2005).

${ }^{22}$ Interview with a CICIR researcher, April 2006, Beijing.

${ }^{23}$ The NZ-China FTA signed on 7 April 2008 provides a limited tariff quota for New Zealand wool $(25,000$ tonnes in 2009) and opens only a few Chinese services industries to New Zealand, with the notable exclusion of financial and telecommunication services.
} 
was set for the realization of the FTA, unlike former Premier Zhu Rongii's proposal of ten years to realize an FTA with ASEAN when he formally proposed the FTA. ${ }^{24}$

\section{Feasibility study}

The responsibility to organize economic study and negotiation of the FTA on the Chinese side then fell on MOFCOM, as China does now with all its FTAs, instead of starting from MFA in the case with ASEAN. The Department of International Cooperation organized the feasibility study because the FTAs were its portfolio. Because of its limited capacity, the Department outsourced the study to the APEC Centre of Nankai University in Tianjin, where there were experts on regional economic cooperation. It had helped the government conduct similar studies before, and so the researchers there were considered knowledgeable of the Chinese economy, and they thought that they only needed to work on the potential partner's economy each time. ${ }^{25}$ The previous Feasibility Studies had not been difficult for them because it was common practice to report that there would be both challenges and opportunities but the latter would weigh more, without detailed sector-by-sector evaluation. However, the Ministry of Finance (MOF), where the Office of Customs Tariff Commission of the State Council resided, was instinctively worried with the potential economic implications of the China-Australia FTA for China, and requested a more accurate and precise study than the ones China had done before to avoid a study that overestimated the net gains to the Chinese economy. As the Australian negotiators have noticed, the Commission plays an important role in setting tariff levels in China. Therefore the MOF requested a researcher from the Quantitative Economics Institute of CASS to join the Chinese research team. ${ }^{26}$

\subsection{Economic Modelling}

The Chinese study group on the FTA was then invited to Australia to learn an economic model - the Monash Multi-Country Model - developed by Monash University in Australia, which was commissioned by the Australian DFAT to conduct the study. According to a Chinese

\footnotetext{
${ }^{24}$ According to a senior researcher at Nankai APEC Centre, Australia wanted to realize the AUCFTA in seven years, while China preferred ten years.

${ }^{25}$ Interview with scholars at the APEC Centre of Nankai University, April 2006.

${ }^{26}$ Interview with a scholar who was commissioned by MOF to participate in the study, Beijing, March 2006.
} 
researcher, the Chinese team were not all serious with studying the model from the beginning. Only when the two governments became concerned with the slow progress of the Feasibility Study did they become fully involved and as a result followed the Australian model without much critique or revision. ${ }^{27}$ A MOFCOM official believed that Australian researchers dominated the process of the Feasibility Study - they not only designed the model but also played a major role in its setting of parameters and assumptions as well as computing, partly because of the limited research capacity in statistics and quantitative study in China. ${ }^{28}$

The modelling study predicted real GDP growth of US\$18 billion for Australia and US\$64 billion for China between 2006 and 2015 because of the liberalization of merchandise and services trade and investment flows between the two countries. It also predicted that employment in the Australian apparel industry would fall by 2015 to about 12 percent below its baseline level (the business-as-usual scenario), while "small" employment declines would occur in the Chinese agricultural and mining sectors. ${ }^{29}$

A confidential study in China by a scholar at the CASS, outsourced by the MOFCOM, on the impact of a possible FTA on Chinese economy found more negative results. It was submitted to the Minister of MOFCOM but not further to the Premier, since President Hu Jintao had given a positive response to Australia's proposal of an AUCFTA. ${ }^{30}$

MOFCOM was not happy with the report of the joint economic modelling as a draft Feasibility Study. In particular, it believed the draft underestimated the potential cost of the AUCFTA to Chinese agriculture and overestimated Australian costs in textiles. MOFCOM listed two reasons for such belief. First, the agricultural tariffs were assumed in the modelling to be reduced from one to three percent to zero, while 70 to 80 percent of reduction was non-tariff barriers but were not counted. Second, China's tariffs of many products should have been calculated as if they would be reduced to zero but the modelling did not. ${ }^{31}$ Eventually the results

\footnotetext{
27 Ibid.

${ }^{28}$ Interview with a MOFCOM official, April 2006, Beijing.

${ }^{29}$ Yinhua Mai et al., "Modelling the Potential Benefits of an Australia-China Free Trade Agreement (an Independent Report Prepared for the Australia-China FTA Feasibility Study)," 2 March 2005.

${ }^{30}$ Interview with the author of the study, March 2006, Beijing.

${ }^{31}$ Interview with a Chinese negotiator at MOFCOM, April 2006.
} 
of the economic modelling did not directly become part of the Feasibility Study as originally planned, but were published by the Australian DFAT as an 'independent report'. ${ }^{32}$

In March 2005, a symposium between government officials and representatives of various industries from both countries was held in Beijing to discuss the possible FTA. Geoff Raby from the Australian DFAT told the Chinese audience that it should have little to fear because Australia's total production is only a small faction of China's own production and consumption. However, the Chinese Ministry of Agriculture expressed concerns about the potential effect of the FTA on grain producers in China. It pointed out that Australian wheat and barley had a large share of the Chinese market, while there was little Chinese corn or rice in Australia. ${ }^{33}$ The Chinese Vice Minister of Commerce, Ms Ma Xiuhong, flagged that any negotiations over agriculture would be tough because if the government did not handle the issue of 740 million peasants properly, "it might cause trouble or social unrest". ${ }^{34}$

Because the political leaders of both countries had given approval of the agenda to conduct the joint feasibility study, MOFCOM could not completely reject the modelling exercise; so it demanded the draft be revised.$^{35}$ As a result, the feasibility study was released on 19 April 2005 "only after painstaking negotiations about wording and presentation". It says that a possible trade deal "could also take into account the impact of further liberalisation on the development of China's dairy production and farmers' incomes", and such a sentence is reproduced seven times in the contexts of cotton, dairy, poultry, wool, wheat, sugar and canola. ${ }^{36}$

\subsection{Market Economy Status}

As mentioned above, a major objective of Beijing to gain from the AUFTA was to obtain Australia's recognition of China's full Market Economy Status (MES), the first of such efforts of Beijing. It is said that Beijing was tipped on the issue in 2002 by an Australian consultant

\footnotetext{
32 "Modelling the Potential Benefits of an Australia-China Free Trade Agreement", available on the DFAT website http://www.dfat.gov.au/geo/china/fta/modelling benefits.pdf.

33 "China fears FTA's impact on farming", ABC Australia, 22 March 2005.

${ }^{34}$ Ibid.

${ }^{35}$ Interviews with Chinese researchers involved in the study, March 2006, Beijing.

${ }^{36}$ John Garnaut, "Give and Take as China Inches Towards Trade Talks," Sydney Morning Herald, 20 April 2005. Australian DFAT and Chinese MOFCOM, "Australia-China Free Trade Agreement Joint Feasibility Study”, http://www.dfat.gov.au/geo/china/fta/feasibility_full.pdf.
} 
because Australia was going to adopt the US-model anti-dumping law soon (which would allow Australian customs authorities to act as sole investigator into anti-dumping cases) and he thought it would be fair for China to request MES from the FTA negotiations so as to reduce the disadvantaged position as an economy in transition. ${ }^{37}$ The Framework agreement with Australia stipulated that formal talks would begin only after China had achieved MES. In April 2004, after Australian Trade Minister Mark Vaile met with top-ranking Chinese ministers in Beijing, Australia agreed to speed up its consideration of China's claim of full Market Economy Status - a position already taken by New Zealand - so as to accelerate the Joint Feasibility Study. Australian commentators observed that it was because the coalition government of Prime Minister John Howard faced an election that year and therefore was keen to make important inroads into Asia to counter claims that it had relegated the region behind its security and economic relations with the US. ${ }^{38}$ At the APEC Trade Ministers Meeting in Chile in June 2004, Chinese Minister of Commerce Bo Xilai reiterated to Mark Vaile that Australia's full recognition to China's Market Economy Status was a necessary condition to start formal bilateral FTA talks.

There were debates in Australia on whether to grant MES to China. Opponents asserted that there were still a lot of remnants of the planned economy in China. However, domestic export-oriented industries argued that granting China MES would not actually put Australia in a passive position in future trade disputes, and more importantly Australia would lose the Chinese market to other countries like ASEAN and New Zealand if it did not facilitate the bilateral FTA negotiations. ${ }^{39}$ New Zealand granted MES to China in March 2004 and the two countries started FTA talks in December. Chinese Vice-Premier Wu Yi even said that she hoped New Zealand

\footnotetext{
${ }^{37}$ Interview with this Australian consultant, Canberra, November 2006.

${ }^{38}$ See "China-Australia: Free trade foreplay to speed up", New Zealand Herald, 29 April 2004. Andrew L. Stoler, "Market Economy Status for China: Implications for Antidumping Protection in Australia" (the Australia-China Free Trade Agreement Conference, Sydney, 13 August 2004).

${ }^{39}$ See "Riding the Chinese Dragon: Opportunities and Challenges for Australia and the World," (Australian Chamber of Commerce and Industry, online at http://www.acci.asn.au/IssuesPapersMain.htm., August 2005. Stoler, "Market Economy Status for China: Implications for Antidumping Protection in Australia". Graeme Thomson, "Trade Policy Issues" (the Australia-China Free Trade Agreement Conference, Sydney, 12-13 August 2004).
} 
would become the first developed country to establish an FTA with China,${ }^{40}$ which sent a clear signal to and added pressure on Canberra to follow suit.

Having taken a more positive attitude on this issue, the Australian DFAT explained to domestic industries that granting MES to China did not mean Australia would lose the right to launch anti-dumping law suits against China at the WTO. ${ }^{41}$ Chinese MOFCOM officials were said to be surprised to hear that. Only after further inquiries on this issue with Australia did MOFCOM get a better understanding, although it still emphasized the importance of bilateral consultation before any legal procedure was taken. ${ }^{42}$ It has since became accepted to Chinese trade officials that its FTA partners retained the rights of anti-dumping, safeguard and countervailing measures at the WTO even if they granted China Market Economy Status and the FTA stipulated a regional alternative, but the agreements always emphasize the importance of consultation for dispute settlement.

In March 2005, the two governments finished the Joint Feasibility Study. On 18 April, John Howard visited Chinese Premier Wen Jiabao and declared Australia's recognition of Market Economy Status for China. That was followed immediately by a 'statement of intent', signed by Australian Ambassador Alan Thomas and Chinese Commerce Minister Bo Xilai, to commence the FTA negotiations. As discussed below, domestic resistance, not least in China, and different approaches between Beijing and Canberra to FTA negotiations have been major obstacles to the negotiation progress.

\section{Negotiations}

After the Feasibility Study was accomplished, the responsibility of negotiations on behalf of China in the AUCFTA was transferred from the International Department to the WTO Department of MOFCOM. That was because MOFCOM judged the FTA negotiation with a developed country would be tough and require high negotiating skills, which the latter was

\footnotetext{
${ }^{40}$ Jize Qin, "New Zealand Set to Hit Another 1st with China," China Daily (North American ed.), 11 June 2005.

${ }^{41}$ Riding the Chinese Dragon: Opportunities and Challenges for Australia and the World, (Australian Chamber of Commerce and Industry, 2005); Andrew L. Stoler, "Market Economy Status for China: Implications for Antidumping Protection in Australia" (the Australia-China Free Trade Agreement Conference, Sydney, 13 August 2004).

${ }^{42}$ Interview with a researcher involved in the Feasibility Study, March 2006.
} 
probably better equipped with after the WTO accession experiences. ${ }^{43}$ Indeed the AUCFTA has been the most difficult among all the FTA initiatives that China has negotiated, in particular because the policymaking institutions have made domestic resistance constraining for trade negotiators, despite the latter's feeling of pressure to realise the FTA according to the schedule set by the leadership. The difficulty also came from different approaches between China and Australia to FTA negotiations.

The bureaucratic capacity of Chinese government agencies for FTA negotiations was another limitation. MOFCOM negotiators lamented that domestic industrial sectors could not provide accurate or even consistent information on which position the MOFCOM could take at the negotiation table. ${ }^{44}$ That caused disappointment among their Australian counterparts that China was not prepared enough for the two sides to proceed with substantial negotiations. According to an Australian observation, China has experienced severe infrastructure difficulties in bureaucratic coordination - "the necessary consultative inter-Ministry processes simply don't always exist. Cross-Ministry dialogue in China is still relatively constrained and policy making still tends to take place in independent silos.... The appointment of the Lead negotiator took place only after the first official 'round' of negotiations, and the negotiation team is stretched. There is a separate negotiator for China's FTA with New Zealand, but much of the rest of the team is the same and some problems have arisen from engaging in both negotiations more or less simultaneously." 45

\subsection{Domestic Interests}

This section demonstrates that Chinese central trade policymakers do not enjoy so much autonomy as in the negotiations on WTO accession or on the China-ASEAN FTA in conducting economic diplomacy. Instead, various domestic sectors try to express their interests and they can be quite stubborn. In this case, domestic resistance in China to further liberalizing trade and investment to Australia beyond the level of WTO commitments has come mostly from agricultural and services sectors. Because of institutional settings, the trade negotiators from

\footnotetext{
${ }^{43}$ Interview with MOFCOM officials, April and May 2006, Beijing.

${ }^{44}$ Interview with a MOFCOM official, April 2006, Beijing.

45 Jane Drake-Brockman, "Chinese Approaches to Negotiation: Implications of Contemporary Practices for the Future" (the China's Future Diplomacy Research and Public Symposium, Canberra, 3-4 July 2006).
} 
MOFCOM are seen by industries as only representatives of domestic interests at the negotiation table, without the authority to decide which sectors to be compromised and which not.

MOFCOM lacks the power of effective inter-ministry coordination.

The participation of industries into the policymaking for this FTA is still largely limited to the channel of state ministries and national commissions, although some big state-owned enterprises seem to have an increasing role. Australian industrial sectors observed that China might be neglecting to put in an equivalent effort into consultation and advocacy with nongovernmental stakeholders for its FTA negotiations as it had done for the WTO. ${ }^{46}$ MOFCOM did send out an online survey to Chinese companies on their opinions on the proposed ChinaAustralia FTA in November 2006. ${ }^{47}$ It received very few email or telephone answers to the online survey. MOFCOM officials think the reason is that Chinese companies usually focus on tax and industrial policies, not on FTAs, and they do not seek to obtain accurate knowledge of FTAs or the overseas investment environment. MOFCOM also conducted surveys through ministries and local governments because "China is too big to gather opinions directly" unlike Australia, where business associations can do a lot of work in this aspect. ${ }^{48}$

However, as the Australian media correctly observed, although the democratic process was not there in China to ensure the participation of local constituencies, especially farmers, in the decision making, there were still pressures from constituencies- particularly the rural sector. $^{49}$

\subsubsection{Agriculture}

Agriculture has been the most difficult sector in the FTA negotiation on goods. From the first round of negotiations, "the Chinese were at pains to say that they were on the defensive on agriculture and would resist liberalization there". ${ }^{50}$ An Agriculture Working Group was specially organized between the two countries at the second round of negotiations to deal with

\footnotetext{
${ }^{46}$ Ibid.

${ }^{47}$ The text of the survey is available on the website of MOFCOM: http://www.mofcom.gov.cn/aarticle/h/redht/200308/20030800117248.html, accessed 14 Aug. 2007.

${ }^{48}$ Interviews with MOFCOM officials, April to May 2007.

${ }^{49}$ Michelle Grattan, "China Free Trade: Icing on the Cake or Sugar Coating?" The Age, 20 April 2005.

${ }^{50}$ Alan Kohler, "FTAs Protectionism in Disguise: Garnaut," Inside Business, ABC Australia, 24 April 2005 .
} 
agricultural and quarantine issues. An Australian newspaper reported that "conflicting objectives are pursued by the Departments of Agriculture and Commerce and the National Development Reform Commission" in the Chinese farm policy environment. ${ }^{51} \mathrm{I}$ will argue that the negotiators from MOFCOM have been sensitive to the protectionist voices of the agricultural sector, which have been very assertive of their vulnerability and, as will be discussed later, the policymaking institution does not confer MOFCOM with the power of 'persuasion'.

\section{Ministry of Agriculture}

The Ministry of Agriculture (MOA) has been the most stubborn opponent to the prospective opening of Chinese agriculture to Australia. ${ }^{52}$ Wool has been a central point of contention. First, MOA asserted that Chinese trade negotiators had already made too many concessions under the WTO. One official claimed that 'we almost lost everything in wool production' after the WTO accession. They pointed out that China's average tariff of agriculture was already low after harsh reductions under the WTO (to around 13\%), while other countries maintained high level of tariffs, non-tariff barriers or subsidies because agriculture was universally a sensitive issue. They argued that although the figures after China's accession into WTO had not shown obvious impacts on agriculture, four years was not long enough to see the real impacts because agriculture has long production cycles. Moreover, in contrast to what they were told to believe during the MOFTEC's pursuit of WTO membership for China, MOA held that the competitiveness of Chinese agriculture had not increased significantly because of liberalization; it was still not as competitive as the US, EU, Australia or New Zealand. In general, MOA doubted the theory that liberalization would help increase productivity and competitiveness, in particular for China's agriculture.

Second, MOA believed that dairy and cattle farmers in China would suffer severely if China was to open the domestic agricultural market to Australia. Even though the range of tariff reduction was not big, it would cause a lot of differences on a huge number of Chinese farmers

\footnotetext{
${ }^{51}$ Garnaut, "Give and Take as China Inches Towards Trade Talks."

52 The information on MOA's views is based on the interviews with MOA officials, May 2006, Beijing.
} 
because they had only minimum means of livelihood. Australia argued that China and Australia produced different kinds of wool and therefore they were not directly competing, and Chinese textile and apparel producers would benefit from cheaper raw materials. Around 50 percent of Australia's wool was exported to China, and the Australian Wool Innovation's report in October 2005 estimated that the proposed FTA would benefit Australian wool growers from an end to the tariff rate quota system on greasy and lightly processed wool enforced by China, and Chinese producers of textiles would benefit from export growth. ${ }^{53}$ The MOA, however, noted that intra-industry trade was already happening between China and Australia and profiting the processing industries in China, while further tariff reduction would damage raw material producers in China.

As for meat, a researcher at the Chinese Academy of Agricultural Science argued that Australia was far more competitive than China in this sector, while at the same time the restructuring policy of the Chinese government was to strengthen the production of pasturebased livestock, which has become a major way to increase employment and income in the countryside for some regions; therefore, protection would be needed. ${ }^{54}$

Some Chinese academics believed, however, that the tariff rates were in fact much lower than the taxes that the government imposed on the farmers. Alleviating taxation was needed much more than tariff protection. Their resistance to tariff reduction was simply a tactic of MOA to divert public attention from taxation to tariff, in order to show that they were acting on behalf of farmers' interests. Keeping the tariffs was in fact mostly to the benefit of domestic dairy processors, which might be paying rents to the government officials but would probably close down because of the competition of Australian imports. The agricultural business associations acted for the interests of companies as well because they had companies as members rather than farmers.

Large staples

Australia also had an advantage over China in large-acre produce, such as wheat, barley, cotton, rice and sugar, in both quality and price. In China, the NDRC monitors the trade of those

\footnotetext{
53 "China FTA to Boost Wool Sales: Report," The Age, 10 October 2005.

${ }^{54}$ Cungen Zhang, "Speech at the Australia-China FTA Agricultural Conference" (Xi'an, 27 September 2006).
} 
'large staples', and state companies maintain monopoly over their trade; in this way, the state maintains tight control over the trade of such goods. Although the import of grains would help China ease the pressure of declining domestic supply, the government policy still remains that China should ensure 95 percent of grains is self-sufficient, in order to guarantee China's food security. ${ }^{55}$ In recent years the supply of domestic wheat has not been able to meet the demand, and Australia has become the second largest import source following Canada, showing strong competitiveness. Besides, China is the world's biggest beer producer, but has long relied on imported barley for the raw material, which was seen as a risk to the 'beer industry's raw materials safety.' China argues that the FTA might result in further decline of wheat and barley production in China, which would result in more unemployment of unskilled farmers, on top of the current 100 million surplus labourers, and inevitably a destabilizing factor of the society. ${ }^{56}$ Australian Trade Minister Simon Crean acknowledges China's concerns for its subsistence farmers, but argues that Australia could help China meet the challenge of food security. ${ }^{57}$ It remains to be seen when the Chinese government would accept that national food security cannot be provided by domestic production alone and whether Australia would be regarded as a reliable provider for China.

As for other large staple products, a researcher at the Research Centre for Rural Economy of MOA, noted that 30 million farmers and 150 million rural population in China relied on cotton production for a living, most of whom had a low income and were vulnerable to market risks including competition from imports, and therefore the state should strengthen macro control over cotton production and protect weak groups. ${ }^{58} \mathrm{~A}$ scholar from Fujian Province held that its sugar production lagged far behind Australia in terms of government 'green box' support, natural conditions, development level and international competitiveness; if China rushed into an FTA with Australia, 40 percent of the domestic sugar market would be lost,

\footnotetext{
${ }^{55}$ See the government white paper Zhongguo de liangshi wenti [China's Food Problem], October 1996, available online at http://www.china.com.cn/ch-book/liangshi/iliangshi.htm.

${ }^{56}$ Baoxiang Qu, "The Changes in Production and Consumption of Wheat and Barley in China and the Development of the Trade between China and Australia" (the Australia-China FTA Agricultural Conference, Xi'an, 27 September 2006).

${ }^{57}$ Simon Crean, "India and China: Australian Engagement at Multiple Levels", Speech to the Melbourne Business School Critical Issues Conference 2008, available online at DFAT website: http://www.trademinister.gov.au/speeches/2008/080410_china-india.html.

${ }^{58}$ Min Du, "Analysis and Prospects of China's Cotton Market after the Entry to WTO" (the AustraliaChina FTA Agricultural Conference, Xi'an, 27 September 2006).
} 
4 million tons of sugar production would be reduced, 1.5 million jobs would be lost; the sugar farmers would lose sugar production-generated revenue of 10 billion yuan and the government would lose tax of 2 billion yuan. Therefore he suggested that the conditions for sugar free trade between China and Australia was immature, and it should be excluded from the negotiations. ${ }^{59}$

\section{Wide areas}

Compared with China's FTA with ASEAN, the potential agricultural trade volume between China and Australia was much bigger, ${ }^{60}$ and the area to be affected by the potential FTA was much wider-Heilongjiang, Liaoning, Shandong, Hebei, Shaanxi, Gansu, Ningxia, Xinjiang and Inner Mongolia in the North and Guangxi and Fujian in the South, instead of only Guangxi, Yunnan and Hainandao in the South in the ASEAN case. According to MOFCOM officials, the representatives at the National People's Congress (NPC), traditionally a venue to discuss domestic issues and merely a 'rubber stamp', have now become more concerned with the impacts of foreign economic policy, including FTAs, on local economies. And the NPC has gained power in China's policymaking as a legislative body vis-à-vis the government. They have submitted formal bills to investigate the problems within a sector caused by certain foreign economic policies, and MOFCOM had to respond and explain such issues to the NPC at special hearings. ${ }^{61}$ The first round of negotiations of the AUCFTA in Australia coincided with the visit of the Chairman of the Standing Committee of the NPC, Wu Bangguo. The People's Daily published a front-page article to report Wu's speech at the Sino-Australian Economic-Trade Cooperation Forum on 23 May, and interpreted that both sides should "have their eyes on the future" and that "China can learn from Australian's experiences in keeping the harmonious economic and social development". ${ }^{62}$

\footnotetext{
${ }^{59}$ Rukai Chen, "The Study of Free Trade between China and Australia on Sugar" (the Australia-China FTA Agricultural Conference, Xi'an, 27 September 2006). Sugar is excluded from tariff reduction by China in the FTA with ASEAN.

${ }^{60}$ Australia was China's fourth largest supplier of cotton, third largest supplier of dairy products and wheat, the largest of supplier of barley and wool from 2001-2003. Australian DFAT and Chinese MOFCOM, “Australia-China Free Trade Agreement Joint Feasibility Study”, March 2005.

${ }^{61}$ Interview with a MOFCOM official, Beijing, May 2007.

62 "Time and Space Outlook on Sino-Australian Cooperation," People's Daily (Overseas Edition), 26 May 2005 http://english.peopledaily.com.cn/200505/26/eng20050526_186934.html.
} 
The 'three agricultural problems'

Whether or not the reduction of tariffs would make a real difference to the life of farmers, agricultural issues were indeed very sensitive in China. "Constructing a harmonious society" is the overarching social and political objective of the Hu-Wen government. An official of MOFCOM commented that it was remarkable that the leadership publicly acknowledged that social problems were pressing in China, and that it showed how important these issues were to the leadership. The incidence of peasant protests have been on the rise in recent years and therefore the government put solving 'three agricultural' problems - peasant, rural area, and agricultural production - on the top of the government policies at the $16^{\text {th }}$ National People's Congress; the three agricultural problems have remained on the No.1 Central Documents, which carry state policies of the highest priority. ${ }^{63}$

\section{Ethnic issues}

Moreover, the provinces in North China that may be affected by the FTA are also areas where many ethnic minorities reside (Xinjiang, Gansu, Ningxia, and Inner Mongolia), including Muslims and Mongolians, most of whom rely on cattle farming for a living. Ethnic issues have become more sensitive in recent years in China's domestic politics, with increasing incidence of violent conflicts between the Han majority and Muslims. ${ }^{64}$ At a bilateral conference on FTA agriculture issues in Xi'an in September 2006, a researcher from the Xinjiang Uygur Autonomous region advised the Chinese government to open wool trade gradually so as to avoid adverse impacts on Chinese fine wool growers, which is essential to "protect the ethnic minorities' economy and maintain the border stability". ${ }^{65}$

\footnotetext{
${ }^{63}$ Interviews with officials and scholars, Beijing, 2006 and 2007. See "Zhongyang guanyu zengjia nongmin shouru ruogan zhengce de yijian" [The Central Government's View on Policies to Increase Peasants' Income", People's Daily, 9 February 2004.

${ }^{64}$ Interviews with MOFCOM officials, Beijing April 2006. Also see for example "Ethnic Conflict Catches China Off Guard", Asian Economic News, 8 Nov. 2004, available online at http://findarticles.com/p/articles/mi_m0WDP/is_2004_Nov_8/ai_n6343590. Mathew D. Moneyhon, 2004, “Taming China's "Wild West": Ethnic Conflict in Xinjiang', Peace, Conflict, and Development: An Interdisciplinary Journal 5, 5: 2-23. Jessica Koch, 2006, "Economic Development and Ethnic Separatism in Western China: A New Model of Peripheral Nationalism”, Murdoch University Asia Research Centre Working Paper No. 134 (Aug. 2006), available online at http://wwwarc.murdoch.edu.au/wp/WP134.pdf. ${ }^{65}$ Kechuan Tian, "Fine Wool Industry in China and the Free Trade between China and Australia" (the Australia-China FTA Agricultural Conference, Xi'an, 27 September 2006).
} 


\section{MOFCOM's position on agriculture}

MOFCOM officials are in general proponents of reform and liberalization, believing competition enhances productivity and free trade benefits consumers. However, they have taken a conservative position on agricultural trade in the FTA negotiations with Australia because protectionist voices from the agricultural sector are strong. Chinese negotiators told their Australian counterparts that although tariff reduction would not cause much difference to Australia, domestic coordination in China was extremely difficult. MOFCOM officials said that the agricultural sector (referring to the Ministry of Agriculture) and business associations - for example, the Chinese Sugar Industry Association and the China Animal Agriculture Association - were all very concerned with the possible impacts of the prospective FTA. These national business associations are non-governmental but are usually funded by the government and affiliated with a state ministry or commission; therefore they are generally supportive of government policies, especially the policies of the government institution they are affiliated with. ${ }^{66}$ They usually provide information and legal services to member producers, and some have become influential among corporate members because they helped Chinese companies win international trade disputes or expand international businesses. Therefore, MOFCOM needs to listen to the opinion of some business associations as well. MOFCOM received a lot of pressure from other government agencies (including MOA and NDRC) to resist further opening of agriculture. As a result, Chinese negotiators told their Australian counterparts that the volume of agricultural trade with Australia was already big, and the prices had been accepted by the companies of both countries; therefore there should have been little demand from the market for the FTA to cover this area.

At the same time, MOFCOM seems to have more sympathy for the agricultural sector than it did during the WTO negotiations. Now it thinks that agriculture is a special and sensitive sector for every country because of political reasons, as has been well demonstrated at the WTO negotiations, and that therefore it is natural that countries would not compromise their domestic

\footnotetext{
${ }^{66}$ For the studies on business associations in China, see Bruce J. Dickson, Red Capitalists in China: The Party, Private Entrepreneurs, and Prospects for Political Change, Cambridge Modern China Series (New York: Cambridge University Press, 2003), 69-85. Scott Kennedy, The Business of Lobbying in China (Cambridge, Mass.: Harvard University Press, 2005). Christopher E. Nevitt, "Private Business Associations in China: Evidence of Civil Society or Local State Power," China Journal 36 (July 1996).
} 
interests in an FTA. It notes that agriculture is widely protected by developed countries because of historical experiences. It is a question, it thinks, for China to consider whether it should follow the path of developed countries - to significantly shrink the agricultural sector and protect what remains with tariffs, quotas and subsidies. ${ }^{67}$ This shows a nuanced development in Chinese policymakers' view towards the agricultural sector, from one that was determined to reduce agricultural population even at the expense of domestic interests, as mentioned in the previous chapter, to a more reflective and cautious attitude towards the policy objective and the ways to achieve that.

\subsubsection{Services and Investment}

Services trade and market access for foreign investment are closely related, and have been another most contentious area in the FTA negotiations between China and Australia. More time was given to the Chinese to prepare the start of negotiations on services and investment than goods, which reflected, as the Australian DFAT said, the fact that services and investment issues were particularly sensitive from China's perspective ${ }^{68}$ Although Australian services industries have been keen to enter the Chinese market, Chinese domestic service providers and relevant government institutions have been clearly resistant to significant liberalization beyond the WTO commitments. That reflects China's conservative position towards domestic reform under an FTA for consideration of economic security, as well as profits generated from monopoly.

\section{Conservative towards reform}

In recent years China has paid more attention to developing the services sector rather than focusing only on manufacturing for industrialization. It also noticed that services trade has become an important part of the multilateral and regional trade talks. ${ }^{69}$ The government wanted to use the WTO to push forward domestic reforms because it was already very difficult for the

\footnotetext{
${ }^{67}$ Interviews with Chinese negotiators from MOFCOM, Beijing, April 2006 and May 2007.

${ }^{68}$ Australian DFAT, “Update: Fifth Round of Negotiations” May 2006, http://www.dfat.gov.au/geo/china/fta/index.html.

${ }^{69}$ MOFCOM, "Director of the Services Trade Department Hu Jingyan talks about China's Services Trade," 2007, http://video.mofcom.gov.cn/video.asp?id=1853.
} 
government alone to carry out further reform. ${ }^{70}$ The WTO was a 'basic national strategy' at that time. However, Beijing is now taking a more conservative approach to reform in this area because economic security and stability have become the priority in China's current reform and opening strategy. When Australian negotiators try to 'educate' the Chinese about the benefits of liberalization, Chinese policymakers say that they are familiar with liberal economic ideas and theories, but they use them only as a reference because they have to consider the situation of the country. Before the ministries or commissions draft a new policy, they always review the policies and experiences in other countries and they have to quote them to persuade the leadership that the proposed policy is plausible. The decision is based on whether it can be implemented. In general, China thinks how much an industry can liberalize depends on its degree of maturity. ${ }^{71}$

Australian negotiators have also tried to persuade China that medium-sized Australian companies can enhance the competitiveness of Chinese companies without their facing the destructive force of big European and American companies, which is consistent with the rhetoric of some Chinese trade officials about the role of FTAs. However, China has been very cautious in such experiments. China has only negotiated FTAs on Trade in Services with Hong Kong, ASEAN, Chile and New Zealand. The one with Hong Kong is special because it is part of China, and China has been careful in defining which counts as a Hong Kong company in order to avoid foreign companies enter China easily through Hong Kong. ASEAN countries have similar levels of development to China, and their requests are regarded as "practical"; the services FTA with ASEAN has actually excluded many sectors that Singapore has advantage in. As mentioned in the previous chapter, China's FTAs with Chile and New Zealand cover similar range of services sectors as the one with ASEAN, and they are all regarded as small economies which would not threaten China's economic security. The EU has tried to obtain preferential treatment from China in services and investment but did not succeed. ${ }^{72}$ The FTAs may in fact improve the competitiveness of Chinese industries and streamlining government regulations with market economy or international standards, but, according to MOFCOM officials,

\footnotetext{
${ }^{70}$ Interviews with MOFCOM officials and Chinese scholars, May 2006 and April 2007.

${ }^{71}$ Interviews, Beijing, 2006 and 2007.

${ }^{72}$ Interview with an official at the China Banking Regulation Commission, Beijing, May 2006.
} 
imposing domestic reforms is not the starting point or motivation of the Chinese government in its pursuit of FTAs.

China prefers a positive-list approach while Australia prefers a negative list approach to services trade liberalisation under the AUCFTA. The Chinese negotiators argue that Australia's negative-list approach is not practical to China because China has yet to know how the sectors will develop in the future; many services that Australia provides have not come into being in China. Therefore Beijing does not know the extent to which China can promise to liberalize those sectors, or give concessions on unknown matters based on the other Party's request. For instance, the Chinese Ministry of Communications responded to Australian's concerns on transport and logistics with the reason that they were in the process of drafting regulations, indicating it was a problem for domestic regulation and laws to solve, not for the FTA. ${ }^{73}$

China is also reluctant to open services trade under the FTA significantly beyond WTO commitments. The government thinks it made substantial concessions under the WTO and carried them out faithfully. In the negotiations before the end of 2006, services regulators, such as the Ministry of Information Industry, the Banking, Insurance, and Securities Regulation Commissions and the Ministry of Information Industry, held that China would honour WTO commitments first, which meant no special treatments would be granted to specific countries before December 2006. After December 2006, Chinese services regulators hold that the impacts on domestic industries still remains to be assessed, before any further liberalization can be experimented or committed. ${ }^{74}$

The banking sector is the most sensitive one for China. The government had realized the necessity of banking reforms, but prefers to do it gradually under domestic control. Although the banking reforms have separated four major commercial banks from the central bank, the commercial banks did not have much independent decision power yet. The central government (the State Council) is still in control, and its policy preference is to ensure safety because it believes that domestic banks are still vulnerable to foreign competition. The Vice President of Bank of China insisted that, compared with banks of developed countries, the situation of

\footnotetext{
${ }^{73}$ DFAT, "Update: Ninth Round of Negotiations", 29 June 2007.

${ }^{74}$ Australia DFAT, "Updates on Progress in the Negotiations", 2007, http://www.dfat.gov.au/geo/china/fta/; see in particular the $8^{\text {th }}$ and $9^{\text {th }}$ rounds of negotiations.
} 
Chinese banks were still not optimistic in efficiency, risk prevention or competitiveness. ${ }^{75}$ The Deputy Director of the Research Bureau of China's central bank said that China had always followed the principle of 'gradual progress' for the liberalization of the banking sector. For foreign investment in Chinese banks, the Chinese regulatory authority, the China Banking Regulatory Commission (CBRC), has set the principle of 'long-term shareholding, corporate structure optimization, business cooperation and competition avoidance'. ${ }^{76}$ China also dismissed Australian banks' complaint that Australian investment banks and fund managers are prejudiced by overly burdensome capitalization and threshold requirements vis-à-vis large American and European institutions. ${ }^{77}$ The CBRC argues that the requirements were decided under the WTO framework for both domestic and foreign banks, not discriminative against Australia.

MOFCOM also argues that the reason most Australian banks cannot compete with European or American banks in China is their size and competitiveness, not China's policy. It suggests that whether or not to loosen the requirement depends on a collective decision in China based on the prospective impacts on politics, foreign banks and domestic banks. MOFCOM will carry out such studies; so do other related ministries, or the leadership appoints one research institute for the task. On important issues, the leadership will make the decision based on opinions from various channels. $^{78}$

The CBRC was also worried that if China gave preferential treatment to Australia, other countries like the US or the EU would demand the same treatment on the basis of WTO principles. MOFCOM, on the other hand, was not worried about this point. It believed that EU and the US would never negotiate an FTA with China because their laws prohibited trade agreements with non-democratic countries. "If the US and the EU complain about China giving

\footnotetext{
${ }^{75}$ Yanling Zhang, "Bring Bank of China's Strengths into Play and Provide Diversified Services to Promote Sino-Australia Trade" (the Australia-China FTA Services Conference, Beijing, 24 April 2006). ${ }^{76}$ Jinpu Jiao, "The Opening up of China's Finance Industry: Ongoing Process and Current Status" (the Australia-China FTA Services Conference, Beijing, 24 April 2006).

${ }^{77}$ Under China's Qualified Foreign Institutional Investor (QFII) scheme, fund managers must have a minimum of US\$10 billion in securities assets under management and must have a minimum 30-year business history, in order to qualify to engage in A share trading. Warwick Smith, "Speech at the Australia-China Fta Services Conference" (Beijing, 24 April 2006).

${ }^{78}$ Interviews with CBRC and MOFCOM officials, Beijing, May 2006 and April 2007.
} 
preferential treatment to other countries," a MOFCOM official said, "we would say they could get it through negotiating an FTA with China."

Before the sixth round of negotiations in September 2006, the Australian Services Roundtable threatened to back out from the negotiation process, and advised the government to freeze the goods negotiations until China significantly improved its offer in services. They argued that neither services issues nor WTO-plus issues such as investment or competition policy could realistically be avoided in any FTA negotiation with a developed economy; and that in Australia's case, it was the services sector where nearly all the gains from an FTA with China were likely to accrue. ${ }^{80}$

\section{Monopoly profits}

As for telecommunication and cultural industries, China has sought protection on the ground of national security. The Ministry of Information Industry (MII) claims that China is worried about information security if foreign companies tap into the intelligence system, but Australia argues that foreign companies like SingTel have been operating in Australia with no worries. A more important reason the MOFCOM has difficulty to facilitate concessions of several services sectors under the FTA, such as telecommunication, transportation and mining, is that a huge amount of profits is generated from monopoly in those sectors, usually by stateowned companies that have become increasingly independent and powerful.

Because of reform, state-owned companies have gained economic benefits from reduced social burdens and autonomy to make market-based business decisions. Meanwhile, because the reform is only partial, they continued to earn rents in the monopolised system, and have become even more powerful in politics because the government relies heavily on them for revenue and employment. The presidents of major state-owned enterprises are often members of important political bodies of the state. Therefore the sectors that benefited from reform have become a significant source of resistance to further reform because their profits and rents under the current system are likely to be lost under external competition. Major state-owned telecom companies

\footnotetext{
${ }^{79}$ Interviews with CBRC and MOFCOM officials, Beijing, May 2006 and May 2007.

${ }^{80}$ Drake-Brockman, "Chinese Approaches to Negotiation".
} 
have pressured the MII not to rush to open markets to foreign competition. ${ }^{81} \mathrm{MOFCOM}$ officials think that monopoly profits and vicious competition between service providers in the telecommunication sector reflect that the state regulation lags behind the development of the sector and therefore needs to be updated. However, it is very difficult for MII to push reform forward. Although the companies are supposed to follow the regulations of the MII, they sometimes resist implementing national policy. When they conduct monopoly activities in the market, the companies reason that they are owned by the state; when they defy government policies, they say that China is now a market economy. ${ }^{82}$

China is also reluctant to open its mining sector to Australia. According to the Minerals Council of Australia, there are all sorts of restrictions in terms of ownership, access to geological data, the distinction between the right to explore and the right to mine, and dispute resolution, as well as lack of transparency of regulations and legal processes ${ }^{83}$ Mining is not listed as a sector for which China has liberalized investment; foreign companies only have the right to explore resources in China but not claim or own them because they are regarded by the Chinese government as 'national assets' and managed by the Ministry of Land and Resources. Although Australian miners hope to get projects off the ground in China, the profits in the mining industry in China is too lucrative for the Chinese to subject it to foreign competition.

Some critics call mining in China a 'grey area conspired by power and capital'. Various reports have also exposed the safety and corruption problems in mining in China; despite the central government's measures to curb them, they are still quite serious. ${ }^{84}$

\section{$\underline{4.1 .3 \mathrm{Weak} \text { offensive interests }}$}

Apart from the market economy status and energy resources as mentioned before, China does not have many strong offensive interests in the FTA with Australia. For Chinese manufacturers, Australia was not an important market because the population is small and tariffs in most sectors were already low; besides, they were not confident that the FTA would reduce

\footnotetext{
${ }^{81}$ Interview with a MII official, May 2007.

${ }^{82}$ Interview with a MOFCOM official, April 2007.

${ }^{83}$ James Attwood, "Australian Miners Place Big Hopes on China FTA," Dow Jones Newswires, 19 April 2005.

${ }^{84}$ Jianjun Tu, "Safety Challenges in China's Coal Mining Industry," China Brief 7, no. 1 (10 January 2007).
} 
many non-tariff barriers for Chinese exports because Australia is well known for its insistence on strict sanitary and phytosanitary (SPS) and technical barriers to trade (TBT) measures.

Chinese officials did indicate that they wanted Chinese manufacturers to make gains in the Australian clothing market through the FTA. However, the Australian Council of Textile and Fashion Industries was assured by senior Australian trade negotiators that China would not get special access to Australia's textile market. ${ }^{85}$ On the other hand, Australian automotive and textiles, clothing and footwear sectors, which are still protected by over $5 \%$ tariff, are strongly opposed to the FTA. The Australian Senate Standing Committee on Foreign Affairs, Defence and Trade was aware that, however, these sectors hire 120,000 Australians, which made DFAT reiterate that they did not have any intention of changing the current industry plans for those sectors under the FTA. ${ }^{86}$ The Australia Manufacturing Workers Union (AMWU) has been adamant in objecting to the FTA. It estimated that the FTA, together with existing competition from China, would cause a loss of 170,000 jobs in manufacturing, only partly offset by limited new employment creation in mining and agriculture, and entire sectors including auto component, textiles and apparel would be wiped out. ${ }^{87}$

China also has advantages in horticulture. The Australian horticulture sector has pressured Canberra to carve out this sector from the FTA. AUSVEG, an association that represents Australia's vegetable growers, said that at least 900 growers would be forced out of the industry if the FTA went ahead, because of China's direct assistance to and looser SPS restrictions on Chinese vegetables, and tough restriction on Australian growers. ${ }^{88}$ However, the Chinese agricultural sector did not have a strong interest in obtaining tariff reduction on these goods through the FTA. It was concerned that even if Australia eliminated agricultural tariffs, Chinese horticultural products would still face very stringent SPS examination. Moreover, a Chinese horticulture expert pointed out that Australia was not among the ten biggest export

\footnotetext{
${ }^{85}$ Katharine Murphy, "FTA with China Won't Cut into Clothes Market," The Australian, 25 May 2005. ${ }^{86}$ Australian Senate Standing Committee on Foreign Affairs, Defence and Trade Estimates, 29 May 2007. ${ }^{87} \mathrm{Jim}$ Stanford and Pat Conroy, The Potential Employment Impacts of an Australia-China Free Trade Agreement (the Australian Manufacturing Workers Union, 2007), 4. Also see Alexandra Smith, "Free Trade Agreement Jeopardizes Local Workers," Sydney Morning Herald, 3 May 2005.

88 "Vegie Growers Face \$500m a Year FTA Loss," The Age, 22 April 2005.
} 
destinations for Chinese fruits and nuts; that China might have a small surplus in horticulture trade but China absolutely had deficit in other large-staple agricultural products. ${ }^{89}$

Based on submissions by ministries or local governments to MOFCOM, the main concern of Chinese companies in doing business with Australia was the difficulty of the movement of natural persons, which inhibit a lot of business activities, especially services. ${ }^{90}$ China was in general interested in better access to the Australian labour market in both skilled and unskilled categories (nurses, construction workers, seasonal agricultural labourers), in part because of rising pressure of domestic unemployment. China thought that given the aging Australian population, Australia should have welcomed Chinese to make up for the labour shortage. Chinese companies also would like to use Chinese managers and workers and to pay them Chinese levels of wage for mining and contracted construction projects in Australia because they insisted that it was difficult to find local workers unless they were to pay double or triple salaries. Besides, the Chinese companies felt it would be easier to manage Chinese workers, and lacked confidence in dealing with Australian labour unions if any dispute arose with Australian workers. ${ }^{91}$ However, Australian negotiators insisted that no FTA could result in free movement of labour as recognized in all trade agreements, including in the WTO, because that is a fundamental aspect of sovereignty. ${ }^{92}$ Also, Australia maintained the position, like other OECD countries, that people movement in the WTO was never intended to cover unskilled workers. The Australian government predicted that visa entry for semi-skilled workers would be highly sensitive in domestic politics. China was also concerned about the requirements for visas and the professional standards, but the Australian government held that they did not have the role in making such decisions; it was the authority of professional bodies.

\footnotetext{
${ }^{89}$ The biggest markets are the US, Japan, Russia, Hong Kong, Indonesia, Malaysia, Germany, the Netherlands and Thailand. Xiuxin Deng, "China's Fruit Production and Bilateral Fruit Trade between China and Australia" (the Australia-China FTA Agricultural Conference, Xi'an, 27 September 2006); Stanford and Conroy, The Potential Employment Impacts of an Australia-China Free Trade Agreement. ${ }^{90}$ Interviews with MOFCOM officials, April and May 2007. Also see Updates on the Australia-China FTA negotiations on the Australian DFAT website: http:/www.dfat.gov.au/geo/china/fta/index.html.

${ }^{91}$ Interviews with MOFCOM officials, May 2007. Also see the speech by the Vice President of China International Contractors Association, Chunhe Diao, "Strengthening Australia-China Cooperation in Engineering \& Contracting and Promote the Common Development of Services Trade" (the AustraliaChina FTA Services Conference, Beijing, 24 April 2006).

${ }^{92}$ Senate Estimates, 116.
} 
Perhaps because of the overwhelming domestic concerns in services, China seems not very interested in gaining access to the Australian services market. Despite signalling that China has identified a few offensive services interests of its own, China has not yet demonstrated any readiness to actually engage. ${ }^{93}$

\subsubsection{The NDRC}

Domestic resistance to the FTA has also come from the National Development and Reforms Commission (NDRC), a powerful institution with oversight of China's industry policies. It seemed to not only have inherited a conservative position on reforms and opening from its former body, the State Planning Agency, but also enjoyed increased power because part of the State Economic and Trade Commission was merged into the Agency to form NDRC, and it has acquired much authority in approving investment licenses since 2004. Other government agencies called the NDRC a 'small state council', because it had departments matching every sector of the economy, and held a higher political position than the ministries. With regards to the AUCFTA, NDRC was concerned about the overall impact on the domestic economic environment because it participated in making economic and investment policies. For instance, it was in charge of major agricultural products (wool, oil, sugar, cotton, rice, wheat) and worked to ensure food security and self-sufficiency. The Australian DFAT was aware of the importance of NDRC in China's policymaking but was concerned that the latter had not been fully involved in the negotiations and therefore MOFCOM could not move beyond traditional agendas and ideas.

MOFCOM thought that it was problematic that the NDRC sent only its Economic and Trade Department to negotiations, which had a similar position in NDRC to that of MOFCOM among the Ministries because this Department communicated with other industrial departments but could not decide on industrial policies. As MOFCOM lamented, it was a common problem with the participation of industrial ministries in the FTA negotiations - they only sent to the negotiations an 'international department', which did not have substantial decision power-and the industrial ministries were often so preoccupied with domestic issues that they paid little

${ }^{93}$ Drake-Brockman, "Chinese Approaches to Negotiation". 
attention to FTAs. Neither did MOFCOM expect them to think of the agenda for negotiation as industries of other countries usually did. Only when necessary, MOFCOM would ask the Ministries to choose from several alternatives for negotiation.

\subsection{Different Approaches}

Apart from the domestic resistance in China (certainly in Australia as well), the different approaches to FTA negotiation and policy formulation between China and Australia have also caused the negotiation process to be slow and difficult. Because of very different economic and regulatory structures between the two countries, they spent a long time to get to know each other's systems and drafting the architecture of the agreement in the first five rounds of negotiations. Even after that, the negotiation process has been 'glacial' because of their contention over the breadth of the FTA's coverage, how much flexibility it should allow, whether it should include WTO-plus issues, and the understanding of the role of state and market in trade policymaking. While a 'commercially meaningful' comprehensive agreement has been the key aim for Australian negotiators, China's most important criteria for FTAs is that they are 'mutually beneficial', which means they bring profits to both Parties. Both Chinese Preside Hu Jintao and Premier Wen Jiabao expressed hopes that both sides could pursue the FTA under the guidelines of "mutual sympathy, mutual understanding, flexibility, pragmatism, and mutual benefit." ${ }^{94}$

\subsubsection{Selective vs. Comprehensive}

China prefers a selective, gradual approach to trade liberalization under the FTA rather than a comprehensive 'single undertaking' as preferred by Australia. ${ }^{95}$ Although the 'complementarity' between the economies of China and Australia has been emphasized by the Chinese and Australian governments, it has not automatically led to a smooth process of FTA

\footnotetext{
${ }^{94}$ Xiao Hu, "Agreements Pave Way for Chinese-Australian FTA," China Daily (North American ed.), 19 April 2005.

${ }^{95}$ An exception may be found in the CEPA with Hong Kong. The MOFCOM admitted that the negotiations were not easy because it had to cover wide areas according to the WTO requirement while taking into account the possible impacts on mainland industries. However, China does not regard CEPA as a real FTA because Hong Kong is part of China, which was why the name was changed from the original plan as FTA to CEPA. Still the CEPA is a 'living' agreement, to which new contents are gradually added.
} 
negotiation. The different levels of development and industrial structures have so far seemed to be an obstacle to both sides' willingness to accommodate the other's interests because of sensitive domestic sectors. That is in contrast to China's FTAs with other developing countries under which they 'understand' each other's difficulties in undertaking liberalization and have allowed each other to carve out sensitive sectors from the FTAs. And unlike what the US achieved through its FTAs with developing countries, Australia does not have enough bargaining power to impose on China a 'commercially meaningful' outcome as understood by Canberra because of its interests in the huge Chinese market. Chinese Vice Minister of Commerce, Liao Xiaoqi, said that "both sides need to consider the practical circumstances where the issues are tackled and ... fully acknowledge the economic development level and special characteristics of their respective economies and carefully consider and accommodate difficulties of each other." 96

China is not willing to open some sectors to Australian competitors, and Beijing thinks Canberra should also adopt a gradual approach to suit itself, without paying much attention to the Australian belief in free trade or to the lobbying power of Australian export-oriented industries. That is probably why in the FTA negotiation with Australia, Chinese negotiators have been confounded by Australia's 'high demand' that China give concessions on all sectors in one agreement, especially agriculture and some services sectors that China regards as fundamental to national economic security. A MOFCOM negotiator said that Australia's requests were too high for China's realities: many of these demands required China to change laws or regulations; and "as the Chinese saying goes, one cannot arrive if too hasty." 97

In its approach to the negotiations, Australia tends to put forward a comprehensive plan and then work on parts while China prefers to talk sector by sector, with relatively easy ones first. ${ }^{98}$ China has preferred to negotiate trade in goods first and trade in services and investment later. The Early Harvest Programs with ASEAN and with Pakistan only included a narrow range

\footnotetext{
${ }^{96}$ Xiaoqi Liao, "Speech at the Australia-China Free Trade Conference" (Shenzhen, 28-29 June 2006). ${ }^{97}$ Interviews with MOFCOM officials, Beijing, April 2007.

${ }^{98}$ Australian DFAT, "Subscriber Update on the Sixth Round of Negotiations of Services and Investment" 13 September 2006. Australia's stance is because domestic interest groups, such as the Australian Services Roundtable, demand a 'single undertaking' so as to maximise their leverage. It is also because some policymakers believe that FTAs should strictly follow the WTO requirement that FTAs should cover 'substantially all trade'.
} 
of goods, and Chinese policymakers proudly call the Early Harvest Programs an excellent 'innovation' of China to give confidence to the partner in the benefits of the prospective FTAs. Even for the final agreement on trade in goods, China prefers to exclude a wide range of sensitive products, and seems very understanding if the partner would like to do so as well. As a result, ASEAN, Pakistan, and Chile all excluded a long list of products from their agreement with China. For the FTA with Australia, the Chinese have reservations about the need for separate chapters on education, telecommunications, financial services, competition policy, electronic commerce and government procurement, and the sort of chapter that Australia wants on investment. ${ }^{99}$

The understanding of the two countries is different on complying with the requirement of GATT Article XXIV that FTAs cover "substantially all trade". China understands it as liberalization as much as the countries can bear, and as long as FTAs promote bilateral trade and investment, then Beijing believes it complies with the WTO. To China, Australia seems 'purist', in stipulating a high percentage $(95-98 \%)$ of trade as meeting the "substantial" coverage requirement.

As a result, the two sides cannot agree to the structure of an offer and have only exchanged some requests instead of the 'usual' means of exchanging offers.

\subsubsection{Border vs. Behind-the-Border}

A scholar at the China Academic of Social Sciences believes that China can learn from Australia in regards to the political system, the legal system and other areas, which will help China's economic reform. ${ }^{100}$ However, reports from the negotiations suggest that China is "badly under-prepared in these areas - or at least wishes to appear so." ${ }^{\text {101 }}$ Chinese regulators hold that many behind-the-border, or WTO-plus issues, such as intellectual property rights (IPR), transparency, technical barriers to trade (TBT) and sanitary and phytosanitary (SPS) measures, cannot be changed overnight. China has been surprised by Australia's draft chapters

\footnotetext{
${ }^{99}$ Budget Estimates, Australian Senate Standing Committee on Foreign Affairs, Defence and Trade, 29 May 2007, online at http://www.aph.gov.au/hansard/senate/commttee/S10267.pdf.

100 John Taylor, "China Fears FTA's Impact on Farming," ABC Australia, 22 March 2005.

${ }^{101}$ Drake-Brockman, "Chinese Approaches to Negotiation".
} 
on behind-the-border issues because it feels that Australia is attempting to alter the Chinese domestic regulation system, and China thinks this wholesale restructuring is not the task of an FTA, which is only supposed to give preferential treatment to the foreign partner under an existing domestic regime. Australian industries, in contrast, believed progress on these issues to be crucial for their business with China. There is a sense in Australia that China has learned the WTO model over the ten year accession process and that China is now a bit stuck on that model which is seen as 'safe'. ${ }^{102}$ The lead negotiator of Australia, Rick Wells, said that the regulatory and behind-the-border issues in many sectors in China - such as a developing legal system, lack of capacity, unpredictable policy changes, the relationship between central and provincial governments and in particular enforcement of intellectual property rights - had become even more opaque and complex since China joined the WTO, and act as road blocks to doing business in China. Therefore, he said, Australia would need to be "extremely vigilant" in enforcing a deal. ${ }^{103}$

The IPR issue has especially been a point of contention. China prefers the IP chapter to be minimalist and non-binding, focused on general principles, cooperation and information exchange, and strongly resists going beyond existing international commitments. ${ }^{104}$ Australian negotiators argue that its manufacturers cannot benefit from the Chinese market because of inadequate IPR protection in China. The Australian Director General of IP Australia, quoting a survey by the Australia Industry Group, identified IPR in China as the most significant nontariff barrier to trade between China and Australia. ${ }^{105}$ The Federation of Automotive Products Manufacturers pointed out that the issue was not tariffs but the lack of protection of intellectual property and non-tariff barriers; they also suspected that the Chinese central and provincial governments extended assistance to illegal activities of Chinese manufacturers. ${ }^{106}$ Beijing has rejected this accusation, reasoning that IPR breaches happen in China despite the central government's best efforts, because of problems in local implementation. The Secretary General

\footnotetext{
102 Ibid.

${ }^{103}$ Catherine Armitage, "Expert Dampens China FTA Hopes," The Australian, 22 June 2005.

${ }^{104}$ Australian DFAT, "Subscriber Update on the Sixth Round of Negotiations of Services and Investment".

${ }^{105}$ Ian Heath, "Intellectual Property and the Free Trade Agreement Process" (the Australia-China Free Trade Conference, Shenzhen, 28-29 June 2006).

106 "Real Deal Is in the Fine Print," The Age, 19 October 2005
} 
of the State Intellectual Property Office of China held that China had already developed a sound IPR legal framework, IPR protection and enforcement, and therefore foreign companies should be able to find solutions through China's legal procedures if they encountered IPR problems. ${ }^{107}$ In the $9^{\text {th }}$ round of negotiations in June 2007, China reiterated its strong concerns regarding the scope and content of Australia's draft IP chapter, and the negotiations remained characterised by two strongly divergent visions for the IP chapter. ${ }^{108}$

China's preference for the chapter on investment is to focus on investment promotion and protection, while Australia prefers liberalization. Because Australia's regulatory arrangements are more open and more developed than those in China, the requests Australia tabled were more extensive than those China tabled with Australia. When Australia requested the removal of a number of barriers affecting investment (predominantly in the mining sector) at the March 2007 round of negotiations, China was surprised that they went to the heart of domestic regulation that underpinned market access. ${ }^{109}$ A Chinese scholar at CASS argues that FTAs are a means through which developed countries pursue their Singapore Agenda (named after the 1996 Singapore ministerial meeting of the WTO--basically about investment, competition policy, and government procurement) lost at the WTO, which will hurt the autonomy of developing countries. ${ }^{110}$ Therefore, although theoretically FTAs could help countries streamline their governance to the standards of market economies by including behind-the-border issues, it actually depends on the preferences of individual countries and the relative power between the negotiating Parties.

\subsubsection{Flexible vs. Rigid}

Another difference lies in the Chinese flexible approach and Australian rigid approach. When Chinese State Councillor Hua Jianmin met with Mark Vaile in January 2006, he said that he hoped "both sides could act in a flexible and pragmatic spirit to advance the negotiations in a

\footnotetext{
${ }^{107}$ Zhonghua Chen, "Speech at the Australia-China Free Trade Conference" (Shenzhen, 28-29 June 2006).

${ }^{108}$ Australian DFAT, “Update: Ninth Round of Negotiations", 29 June 2007. http://www.dfat.gov.au/geo/china/fta/

${ }^{109}$ Australian DFAT, "Update: Eighth Round of Negotiations", http://www.dfat.gov.au/geo/china/fta/.

${ }^{110}$ Fan He, "Bing Bu Ziyou De Ziyou Xieding [Ftas Not Free]," The Economic Observer, 18 December 2005 http://finance.sina.com.cn/j/20051218/18092207715.shtml.
} 
positive and steady manner". ${ }^{111}$ As mentioned before, this difference was already exemplified during the Feasibility Study. When China agrees to a proposal of an FTA, it usually says the FTA will bring both opportunities and challenges but on the whole it will be beneficial, without specific assessments. In this way, the central decision makers try to dismiss potential costs on both sides. China thinks Australia's market is already very open (average tariff is below 10\%), and so China's prospective benefits from the FTA will not be as much as Australia claims. It is probably part of the Chinese diplomatic culture that they give an in-principle approval if there is no crucial problem. Implementation of the in-principle agreement usually means selecting benefits while avoiding costs to the domestic economy. In other words, promoting export and avoid import competition, which is apparently not desirable for the FTA partner.

China's attempt to hide challenges does not always succeed. On the one hand, when Australia presented quantitative results of their potential loss, China was doubtful but it could not provide an alternative calculation. As mentioned before, the Australian manufacturing sector has been strongly opposed to the FTA on the grounds of prospective loss of 170,000 jobs, while China tried to say that Australia did not have advantage in manufacturing anyway. On the other hand, Chinese negotiators are often in an embarrassing situation at the negotiating table whereby Chinese domestic industrial sectors provide inaccurate or inconsistent statistics and offers.

The differences between Chinese flexible and Australian rigid approaches also reflect in the following issues:

Rules of Origin: China prefers a regional value added approach, ${ }^{112}$ which allows China to have a different set of Rules of Origin for each of its FTAs, while Australia prefers the change of classification approach which applies the same rules for all its FTAs and requires less administrative workload.

Dispute Settlement Mechanism: China acknowledges the importance of stipulating a dispute settlement mechanism in the FTA, according to a MOFCOM negotiator, but China

\footnotetext{
111 "Bilateral Relations", China MFA website at http://www.fmprc.gov.cn/eng/wjb/zzjg/bmdyzs/gjlb/3377/default.htm

112 The requirement under an FTA that a certain percentage of the value of the final product should be added in the region if that product is to be recognized as made in this region.
} 
prefers bilateral negotiation and friendly consultation, with third-party adjudication as the last resort. A Chinese negotiator pointed out that NAFTA members have only used that mechanism only once but resorted most of the time to the WTO. China also prefers a simple and practical procedure for dispute settlement to the complicated procedure under the WTO. ${ }^{113}$

Negotiation Scheduling: Australia has very specific plans for the FTA negotiation but China cannot decide on many details including the schedule of negotiations because the government has to deal with many domestic issues and the negotiation team is overstretched. That is seen by Australia as a sign of lack of sincerity. Moreover, China seems to have difficulty committing quickly to written text. Draft text on about three quarters of the proposed structure tabled at the negotiating round in May 2006 was drafted by Australia. ${ }^{114}$ In the round in May 2006, Australia complained that China failed to meet the promise to give a new improved offer on tariff reduction but Chinese negotiators said that they could not have made such a promise given the difficult situation marked by domestic resistance and limited bureaucratic capacity. China's failure to table a specific offer on tariff reductions in September 2006 made Australian negotiators frustrated, who then put their offer on hold. After the seventh round of talks in December 2006, Australia refused to continue talks on tariffs unless the Chinese submitted a substantially better offer. Chinese officials have since repeated that they were preparing to submit a better offer, but the timing remained vague. ${ }^{115}$

\subsubsection{State vs. Market}

Many of the above differences, in particular those on the behind-the-border issues, are a reflection of the systemic differences between China as an economy in transition and Australia as a market economy. Or, more state versus more market for the formulation and implementation of foreign economic policy, although FTA negotiations are between the governments. For instance, as mentioned previously, China requested Australia to include a clause on the stable supply of resources into the FTA. He Yafei, Director of North America and

${ }^{113}$ Australian DFAT, "Update on the Negotiations", 11 Nov. 2005, http://www.dfat.gov.au/geo/china/fta/index.html. Min Rong, "Speech at the Australia-China Free Trade Conference" (Shenzhen, 28-29 June 2006), 144-45.

${ }^{114}$ Drake-Brockman, "Chinese Approaches to Negotiation".

${ }^{115}$ Mary-Anne Toy, "China Free Trade Talks Drag on, and on, and On," Sydney Morning Herald, 23 June 2007. 
Oceania Department of MFA, told Australian media before Howard's visit in April 2005 that while the increase of iron ore prices was a commercial matter, Canberra "can certainly encourage companies to take a long-term point of view in setting prices... don't just look at the benefits under their noses." ${ }^{\prime 16}$ Whereas the Australian government insists that prices are purely business decisions by private companies, some of which are multinational corporations; the government should not and cannot intervene because Australia is a market economy.

China believes the Australian government has the decision power over the FTA, and that the only difference compared with China is that the Australian government gathers more information from and communicates more with industries. ${ }^{117}$ This is perhaps a reasonable assumption considering the Australian government's decisive role in forming an FTA with the US despite domestic societal opposition. ${ }^{118}$ It is why China does not have as wide or deep consultations with domestic private sectors as Australia does; nor does it run a substantial advocacy program in Australia. Australia runs an extensive program of advocacy on the China FTA, in an attempt to change domestic opinion within China, which takes the form of visits to Australia by journalists who, on their return to China, have written articles in favour of the FTA in various areas of interest to Australia, including agriculture and services. They have also invited influential Chinese in government and academia in the hope that they could "build a more receptive mood in China for the FTA". However, for China's offensive interests, China does not have a similar program of advocacy in Australia. ${ }^{119}$ Australian industries felt that "China seemed to have got away with largely leaving advocacy in Australia of the Australia/China FTA to the Australian Government to handle." They pointed out that "Chinese Embassy public commentary focused more on delivering a message regarding China's

\footnotetext{
${ }^{116} \mathrm{Hu}$, "Agreements Pave Way for Chinese-Australian FTA."

${ }^{117}$ Interview with a MOFCOM official, Beijing, April 2007.

${ }^{118}$ On the Australia-US FTA, see Ann Capling, All the Way with the USA: Australia, the U.S., and Free Trade (Sydney: University of New South Wales Press, 2005). Tor Krever, "The US-Australia Free Trade Agreement: The Interface between Partisan Politics and National Objectives," Australian Journal of Political Science 41, no. 1 (March 2006). Linda Weiss, Elizabeth Thurbon, and John A. Mathews, How to Kill a Country: Australia's Devastating Trade Deal with the United States (Crows Nest, N.S.W.: Allen \& Unwin, 2004). Ross Gittins, "FTA: Bad Politics Drives out Good Economics," Sydney Morning Herald, 9 August 2004. On Australia's trade politics, see Ann Capling, Australia and the Global Trade System: From Havana to Seattle (Cambridge; New York: Cambridge University Press, 2001). Stuart Harris, "The Merger of the Foreign Affairs and Trade Departments Revisited," Australian Journal of International Affairs 56, no. 2 (2002). John Kunkel, "Australian Trade Policy in an Age of Globalization," Australian Journal of International Affairs 56, no. 2 (2002).

${ }^{119}$ Senate Estimates, 114.
} 
sensitivities in for example agriculture, than on any advantage of an FTA for the Australian industry audience."120

Because of the above mentioned differences between China and Australia, the FTA negotiations have remained, as the Australian Trade Minister Warren Truss described, "tortuous". ${ }^{121}$ Upon the launch of the negotiations, the Australian Prime Minister John Howard declined to put a deadline on when the FTA was aimed to be achieved, saying that "we should not underestimate the complexity of the negotiating process", suggesting it would just be "icing on an already rich cake." ${ }^{122}$ He also conceded that "there is a lot of goodwill around, but not that good". ${ }^{123}$ China's continued reluctance to give preferential treatment to Australian services and investment beyond its commitments under the GATS and lack of advocacy in Australia triggered the chief Australian negotiator, Ric Wells, to make the extraordinary comment at an Australian Parliamentary Committee hearing that "the Chinese government doesn't want an FTA." 124 The Chinese negotiators indicated to their Australian counterparts that they would like to use high-level visits to achieve some breakthroughs. But, from the Australian point of view, it was very "incumbent" on the Chinese to move on some important areas. ${ }^{125}$ Although Chinese negotiators are under pressure to realize the target set by Chinese Premier Wen Jiabao in April 2006 that a major breakthrough in China-Australia FTA negotiation should be made in the next one or two years, they feel that such a development is unlikely unless the leadership intervenes in the negotiation process and imposes a settlement on domestic industries. ${ }^{126}$ Indeed, Hu Jintao did not bring a gift — renewed promises for the FTA — to his Australian counterpart during the 2007 APEC Summit in Sydney, because Beijing was watching the upcoming election in Australia. ${ }^{127}$ China succeeded though, in signing energy contracts with Australian companies on

\footnotetext{
${ }^{120}$ Drake-Brockman, "Chinese Approaches to Negotiation".

${ }^{121}$ Graeme Dobell, "China Trade Negotiations 'Tortuous' Says Truss," ABC News, 16 June 2007 http://www.abc.net.au/news/stories/2007/06/16/1953209.htm.

${ }^{122}$ Grattan, "China Free Trade."

${ }^{123}$ Brown, "Long March for Australia, China FTA."

${ }^{124}$ Budget Estimates, Australian Senate Standing Committee on Foreign Affairs, Defence and Trade, 29 May 2007, online at http://www.aph.gov.au/hansard/senate/commttee/S10267.pdf, page 114.

${ }^{125}$ Australian Senate Standing Committee on Foreign Affairs, Defence and Trade, Proof Committee Hansard Estimates, 29 May 2007, 103.

${ }^{126}$ Interviews with MOFCOM officials, Beijing, April 2007.

${ }^{127}$ Interviews with MOFCOM officials, Beijing, April 2007.
} 
the sidelines of the APEC summit, arguably even more reducing the utility of the FTA for China in securing energy supply. During the 10th Round of Negotiations in late 2007, a Chinese negotiator asked his counterparts: "Why do we need the FTA, since bilateral trade is already developing well?" 128 The new Prime Minister Kevin Rudd's first visit to Beijing in April 2008 was mainly aimed at rekindling the FTA negotiation; although the Chinese Premier agreed to restart FTA negotiations, he gave few promises despite Beijing's appreciation of Rudd's ability to speak mandarin and his emphasis on cooperation with China and with Asia more broadly. One reason for that could be Rudd's criticism of human rights in Tibet during his China visit in April 2008, which caused a strong negative reaction by Chinese officials. ${ }^{129}$

\section{Conclusion}

As discussed in Chapter 2, this study is interested in the role of institutions in policymaking, especially how they structures the interactions among preferences, and the development of institutions. I have suggested that three features of institutions might be important when analyzing their role in policymaking: the degree of insulation of the central policymaker from domestic interests, the degree of collective action of domestic interests, and the degree of fragmentation of the policymaking power. As will be discussed in this section, the case of China's policymaking towards the FTA with Australia demonstrates that these three features of institutions are key factors to explain China's policies. As to the development of institutions, this case supports the idea that ad-hoc institutional arrangements created to deal with new policy issues may evolve through time to become more stable institutions, and that 'institutional learning' through external interactions as well as the change in the chief agency can be sources of institutional change.

\subsection{Insulation}

China's policymaking process of the AUCFTA shows that the state does not have as much autonomy in conducting economic diplomacy as during the WTO accession negotiations or the China-ASEAN FTA negotiations, or as conventional wisdom suggests; rather, it has to

\footnotetext{
${ }^{128}$ Interview with a MOFCOM official, Canberra, October 2007.

${ }^{129}$ Stephen McDonell, "China Sprays Rudd over Tibet Human Rights Claims”, ABC News, 9 April 2008.
} 
accommodate domestic interests, especially when the central policymaker is not well insulated from domestic pressures.

The Chinese leadership and the State Council still have a lot of autonomy in China's foreign economic policymaking. They command absolute authority over ministries and domestic industrial sectors. All Chinese government agencies think that the FTA with Australia is going to be realized because both $\mathrm{Hu}$ and Wen have given support to it. Both Chinese and Australian negotiators acknowledged the impetus given to the negotiations by the visit to Australia of Premier Wen Jiabao in April 2006 and his proposal that both sides aim to achieve breakthroughs in the next one or two years. ${ }^{130}$ Wen was accompanied by the Minister of Commerce and the Chairman of NDRC, showing much attention the Chinese leadership paid to the FTA. In the negotiation round a month later, China seemed to become more flexible on some issues that had been highly sensitive. For instance, China accepted the single undertaking approach, agreed to include provisions on investment and government procurement in the FTA, and agreed to Australia's proposal that they table text on investment at the next meeting in September.

However, because of increasingly serious social problems in China, the leadership has raised 'building a harmonious society' as the highest policy objective. It has to consider possible social impacts of foreign economic policies, especially those associated with farmers and ethnic minorities. MOFCOM officials all think that Wen Jiabao is more cautious than Zhu Rongji on reform; for instance, the priority of the central government policy is on agriculture and therefore would not ask much concession from the Ministry of Agriculture. At his meeting with the Australian Prime Minister John Howard in Shenzhen in September 2006, Wen reiterated that China had good faith in negotiating the FTA with Australia, and that both sides should demonstrate 'mutual understanding and accommodation'. The Vice Minister of Commerce, Liao Xiaoqi, quoted Wen's words at a subsequent FTA conference between China and Australia and said that MOFCOM would follow those guiding principles. ${ }^{131}$

\footnotetext{
${ }^{130}$ Australian DFAT, “Update: Fifth Round of Negotiations” May 2006 http://www.dfat.gov.au/geo/china/fta/index.html.

${ }^{131}$ Liao, "Speech at the Australia-China Free Trade Conference".
} 
More importantly in this case, as Australian DFAT said, Premier Wen's expressed desire to move forward with the negotiations did not by itself signal any diminution of concern on China's part over what it considered its sensitive sectors. ${ }^{132}$ Because MOFCOM is designated with the power to negotiate the FTA, the centre of policymaking power is with MOFCOM but MOFCOM does not have the formal authority to settle conflicting interests. According to MOFCOM officials, the WTO accession could be negotiated more easily because MOFTEC was delegated with a lot of power then by the leadership, which was strongly committed to a positive outcome. As mentioned previously, the WTO membership was linked to national pride in the domestic discourse; that is because to Chinese, the WTO accession was a symbol of the international recognition of China's past efforts in market reform, and a ticket to equal trading rights that China deserved; the competence of the leadership was at stake because it had publicly pursued the membership for many years; besides, the government needed the external pressure from the WTO to push forward domestic reforms that it deemed necessary. If domestic coordination on the negotiation agenda became difficult, MOFTEC could report directly to President Jiang Zemin's office and get the paramount authorization to put pressure on industrial ministries. The WTO Working Group was made up of the Ministers and a Vice Premier. Any problem within one industry would not be so big with the Ministers if they were called into meeting by a Premier. However, an imperative tantamount to that for the WTO accession is lacking for the achievement of the AUCFTA - China is the demandeur in the negotiations, and the Chinese government does not regard FTAs as a proper mechanism for propelling domestic reform.

Moreover, MOFCOM is weaker than MOFTEC. The State Council expects MOFCOM to coordinate among the industries and not to push the work of coordination to the State Council. MOFCOM claims that industrial ministries accept MOFCOM's role of coordination because it is neutral - without preference for any particular sectors. However, industrial ministries generally believe that MOFCOM holds a liberal point of view because it regards trade

${ }^{132}$ Australia DFAT, "Update: Visit of Chinese Premier", April 2006, http://www.dfat.gov.au/geo/china/fta/index.html. 
promotion as their work achievement. ${ }^{133}$ Because MOFCOM has the same political rank as other industrial ministries and even lower than some national commissions like the NDRC, it is easily subject to pressure from other ministries and commissions to accommodate their interests. Even though MOFCOM is in general supportive of reform and economic liberalization, it has a lot of difficulty in persuading domestic sectors to subscribe to this belief and to agree to open under the FTA. On the contrary, domestic sectors, such as agriculture and telecommunication, have become more assertive of their interests than they were during the WTO accession. The increased assertion of domestic interests comes from experience or resentment from the WTO accession for some sectors, and from partial reform that produced monopoly profits for other sectors. They have forced or persuaded MOFCOM to take a conservative position at the FTA negotiations.

\subsection{Collective action}

The adage seems supported by the lobbying activities on the central policymakers regarding China's policy on the AUCFTA - winners do not engage in as effective collection action as losers do. Potential winners - export-oriented industries such as manufacturing and energy and resources companies - have not pushed hard for the progress of the FTA negotiation. Apart from the reason that manufacturers do not view Australia as one of the most important markets, as mentioned before, even though some are very interested in the Australian market, they do not have the institution to organize collective action. After the government reform in 2003, the management of manufacturing in China has been largely marketized and decentralized. A number of national industrial associations were formed from former ministries but their function has reduced largely from regulation to information supply, and their power in national politics has been greatly reduced. Business activities of manufacturing have been dominated by major state-owned enterprises, foreign invested corporations and other private firms. Key sectors are the textile and automobile, which have only business associations but no ministries at the national level. Therefore their degree of collective action is constrained by the loose institutional structure of the regulation system and the limited power of business associations.

${ }^{133}$ Interviews, Beijing, 2006 and 2007. 
As for energy and resource companies, they have expressed hope for the FTA to help them gain more access to Australian resources, but because that is in accordance with the state's motivation behind this FTA, they have trusted that the government would try to achieve this objective anyway and therefore has not been mobilized to add pressure on negotiators. Moreover, the government has achieved a few energy cooperation agreements outside the FTA framework. As a result, the potential winners from the FTA have not pressured Chinese negotiators to accelerate the negotiation.

In contrary, the potential losers from the FTA - agricultural and services sectors - have strongly resisted the FTA through their respective ministries - although not the FTA as a whole since the leadership supports it, they resist significant liberalization in their sectors under the FTA. Although horticulture would gain from the FTA, the representation of the agricultural sector at the negotiation is by the Ministry of Agriculture, which is focused on the greater losses for other farmers. There is no labour union among the farmers in China, but the agricultural problem has become so prominent that the Ministry gained power in Chinese policymaking through assuming the role of the representative of farmers. The role of MOA was so important that it was invited by the State Council to participate directly in the negotiations; hence a unified protectionist voice of Chinese agriculture without the danger of being jeopardised by MOFCOM.

The ministries and commissions in charge of services sectors participated in the negotiations as well. Because many Chinese services sectors central to Australia's interest are still at a preliminary stage of liberalization, the state still has a dominant role in them. These sectors, including banking, telecommunication, transportation, and education, are each managed by a ministry or ministerial-level national commission, and these agencies naturally have more power and a higher degree of organization than quasi-governmental or private business associations. The agency overlooking investment policies is the NDRC, a powerful agency that has a higher rank than MOFCOM and has a generally conservative attitude towards liberalization as inherited from the State Planning Committee. 


\subsection{Fragmentation}

Whereas in the case of the China-ASEAN FTA, MFA played a leading role at the beginning and MOFCOM later took over the political and economic authority over policymaking and largely followed the same direction towards cooperation, in the case of the AUCFTA, the power of policymaking is more fragmented. Because of less involvement of MFA and the leadership, the policymaking of the AUCFTA has been less driven by political motivations and the conflicting domestic economic interests have become more prominent.

Because the power of trade, investment and industrial policymaking is fragmented among MOFCOM, the NDRC, and other ministerial-level government agencies, MOFCOM cannot propel trade liberalization without the consent of others. For instance, MOFCOM has to get the co-signature [hui qian] of MOA and NRDC on an negotiation agenda of agriculture before it can submit to the State Council to seek authorization. That is very difficult for MOFCOM to achieve. MOFCOM has the authority to organize inter-ministerial meetings but does not have the power to negotiate a concession with them; instead, because the domestic industries have a direct role in FTA negotiations (agriculture, banking, telecommunication, etc.), the power is in effect distributed to various industrial ministries and central commissions. Moreover, because the power of industrial policymaking is fragmented among industrial ministries, the NDRC and some other regulatory commissions, and Chinese ministries often lack communication as Australian negotiators observed, the ministries were sometimes surprised with Australia's list of barriers to trade in China that was caused by the regulation of other ministries or commissions, and different agencies may come up with different statistics.

\subsection{Institutional change}

Apart from the decisive role of institutions in structuring the interactions between preferences in policymaking, this case study of China's policymaking on the AUCFTA also supports another proposal by historical institutionalism that institutions resist change, although changes do happen under certain circumstances.

Although institutions of the planned economy have been reformed by Zhu Rongii, their successors have still inherited much of their perceptions and approaches towards economic 
management. The NDRC and the Ministry of Land and Resources both hold a conservative attitude towards liberalization, and emphasize state control on the grounds of national security, be it food, financial or energy security. They would only give in to a national policy of higher strategic value, such as the WTO membership, but not FTAs which serve more instrumental purposes for the state.

Partial reform has caused initial beneficiaries to resist further liberalization because of existing rents and uncertain outcomes for them. Currently in China, rents and monopoly profits widely exist in sectors like telecommunication, transportation and investment regimes. They are strongly opposed to opening their sectors to Australian competition, on the grounds of national economic security, information security or the need to protect infant industries. At the same time, export-oriented sectors like textile and other manufacturing sectors have lost a lot of political clout in central policymaking because reform there was more thorough. As a result, they cannot become a strong lobbying power for the realization of the FTA.

However, institutions do develop or change when ad-hoc arrangements created upon the challenge of a new issue area stabilise, when institutions learn from external sources, or when the chief agency changes. Since China's first FTA with ASEAN, China has negotiated FTAs with over twenty countries or regional groups, and the ad-hoc arrangement for the ChinaASEAN FTA has gradually become the current 'working mechanism of FTA decision making, ${ }^{134}$ It starts with the political evaluation of the partner country, since most of China's FTAs have been proposed by other countries. If the partner is 'politically qualified', MOFCOM will lead the feasibility study and the negotiations. Once the feasibility study starts, the FTA is bound to be realized at some stage and the result of the study is usually positive on the wholeif the two parties are not both eager to form the FTA, the stage of the feasibility study could be prolonged. MOFCOM then organizes domestic sectors to set the agenda for negotiation, through communications with ministries and national commissions. The MOFCOM tries to solve conflicting interests and problems at a working level in the form of joint 'working meetings' or circulating documents; if it cannot, it seeks the last resort - asking the State Council to intervene.

${ }^{134}$ Interviews with MOFCOM officials, May 2007. 
The last resort - the intervention of the State Council in FTA negotiations - has not been easily available in recent years because of rising domestic problems and the relative ease of FTA negotiations with developing countries. The nature of Australia as the first major developed country that China has negotiated an FTA with has posed new challenges for China's working mechanism of FTA policymaking. Despite the reallocation of responsibility from the International Department to the WTO Department equipped with highly developed international trade negotiation skills, the lack of authority of MOFCOM as the lead agency to coordinate domestic interests has hindered China's ability to 'give' to the FTA partner and therefore in turn the ability to 'take'.

Institutional learning could have happened if China aims to streamline the cooperation between the two countries. The feasibility study, as in all other countries, has become an inherent part of the FTA policymaking process because China needs to participate in the joint study program as other countries do. MOFCOM also agreed to participate in a 12 months' programme of learning negotiating skills from Australia at the first round of negotiations. That has been criticized as if Australia attempts to teach China on the negotiating front. ${ }^{135}$ Chinese officials have also dismissed Australia's education of Western liberal economic ideals as unpractical to realities in China. However, as revealed in the negotiation process with Australia, many Chinese sectors resist deep cooperation - on behind-the-border issues - and therefore they are not willing to follow the model of Australian regulation to adjust their systems even though Australia claims to have one of the best regulatory systems in the world. That has become one of the obstacles of bilateral cooperation. Still, China has recently set up a National Business Association of Services, which can be a counterpart organization to the Australian Services Roundtable and improve communication between private sectors between the two countries.

In response to the problem of the lack of an overarching agency in FTA policymaking and because of the rising importance of FTAs as an instrument of China's economic diplomacy, China was said in early 2007 to be considering changing the WTO Work Leading Group of the State Council into the WTO-FTA Work Leading Group, or extending the WTO Work Leading

${ }^{135}$ Drake-Brockman, "Chinese Approaches to Negotiation". 
Group's portfolio to cover FTAs. ${ }^{136}$ This Leading Group played an important role in China's WTO accession and Vice Premier Wu Yi leads the group. This change of the leading agency will probably strengthen coordination of domestic interests but it remains to be seen if the dilemma MOFCOM now faces will be solved, because as one MOFCOM official said, China is changing rapidly, not only the economic development but also the political picture.

${ }^{136}$ Interview with a MOFCOM official, Beijing, April 2007. 


\section{Introduction}

Although it may not attract as much limelight as street protests against free trade agreements, international financial cooperation directly concerns national financial security and involves intense behind-the-scene negotiations between national governments, usually surrounding the distribution of voting power among members and the degree of compromise of national sovereignty.

During the Asian financial crisis in 1997, East Asian countries started to consider ways of regional financial cooperation to prevent future crises. With few exceptions, economists believe that trade integration is a foundation of financial integration. In other words, financial integration represents a higher level of economic integration than free trade, and requires a sufficient level of intra-regional trade to have previously been realized. ${ }^{1}$ The best example is the European Union (EU), where the free flow of trade preceded the free flow of capital and the creation of the Euro as the single regional currency. East Asia, ${ }^{2}$ upon its agreement on the Chiang Mai Initiative in 2000, had celebrated its exception to that rule; it seemed that the first achievement in regional economic integration was in the area of finance instead of trade, regardless of the fact that bilateral swap arrangements are only a shallow form of financial cooperation that has existed among industrialised countries for a long time. However, although some progress has been made during the ten years since the Asian financial crisis, East Asian financial cooperation has yet to achieve several key milestones in a meaningful regional financial cooperation, even though intra-regional trade and sub-regional free trade agreements have developed significantly. ${ }^{3}$

\footnotetext{
${ }^{1}$ Robert Mundell, "A Theory of Optimum Currency Areas," The American Economic Review 51 (1961). Barry Eichengreen, "Real and Pseudo Preconditions for an Asian Monetary Union" (paper presented at the paper presented at the Asian Development Bank High-Level Conference on Asia's Economic Cooperation and Integration, Manila, July 2004). Barry Eichengreen, "International Monetary Arrangements: Is There a Monetary Union in Asia's Future?" Brookings Review 15 (Spring 1997). Some challenge this view, see Heribert Dieter and Richard Higgot, "Exploring Alternative Theories of Economic Regionalism: From Trade to Finance in Asian Co-operation?" Review of International Political Economy 10, no. 3 (August 2003).

${ }^{2}$ East Asia refers to Northeast Asia and Southeast Asia, or ten ASEAN countries plus China, Korea, Japan.

3 See for example, John Ravenhill, "A Three Bloc World? The New East Asian Regionalism," International Relations of the Asia-Pacific 2 (2002).
} 
China has taken quite opposite positions towards initiatives on East Asian financial cooperation. For instance, it did not support the proposed Asian Monetary Fund in 1997 or the proposed Asian Currency Unit, but showed enthusiastic support for the Chiang Mai Initiative and milder support for later plans for upgrading the CMI. What political and economic considerations have led to China's changing policies on regional financial cooperation? And, why have those considerations prevailed in China's policymaking over other possible considerations? By analyzing China's policymaking on regional financial cooperation, I argue that lack of political trust towards other countries and the limited level of domestic economic development are major obstacles to China's commitment to deep financial cooperation because they hinder a country's willingness to give up part of its sovereignty, which is essential to deep regional cooperation. Domestic policymaking institutions play an important role in granting much weight to the opinion of the foreign policy apparatus and in concentrating power in a few central agencies (in particular the central bank) that prioritise national economic security over international cooperation. The combination of those factors has led to China's highly strategic decisions and a generally more conservative position on regional financial cooperation than the scholars or some government agencies like the Ministry of Finance or Commerce would arguably prefer.

In this chapter, I will first discuss the impacts of the Asian financial crisis on China, not only economic and political impacts, but importantly ideational impacts - or what lessons Chinese policymakers and scholars learned from the crisis. Secondly, I will analyze China's policymaking on Japan's proposal of an Asian Monetary Fund in 1997, and on the Chiang Mai Initiative since 2000. I will address an important question: why did China not support the AMF but subsequently did support the CMI? Then I will look at China's conservative stance on upgrading CMI, as well as on regional exchange rate coordination. ${ }^{4}$ I will conclude by highlighting the institutional features of China's policymaking on regional financial cooperation, in comparison with trade policymaking, as an explanation for China's different attitudes in these areas.

\footnotetext{
${ }^{4}$ Although $\mathrm{ABM}$ and $\mathrm{ABF}$ are also important projects, they were set up mainly for the participation of private sectors. Foreign aid is not included in this study either, because it is often a unilateral decision, although it is also considered part of economic diplomacy by the Chinese government.
} 
Although the Asian financial crisis did not engulf China, it had economic and political impacts on China, and most importantly Chinese policymakers learned several lessons from the crisis, which continue to inform its policies towards domestic reform and international financial integration today.

\subsection{Economic costs}

China did not experience a financial or economic crisis when the Asian financial crisis from 1997 to 1998 hit most countries in the region, characterised by massive outflow of international short-term capitals, sharp devaluation of the national currencies and difficulty in balance of payments. However, the crisis did have adverse impacts on the Chinese economy, as detailed by a Chinese economist at the Central Party School. ${ }^{5}$ First, because of the devaluation of regional currencies and hence the reduced purchasing power of consumers in the neighbouring countries, China's growth rate of exports to East Asia declined significantly. Since August 1997, China's volume of contracted exports to East Asia started to decline. In the first quarter of 1998, China's exports to Japan declined by $2.5 \%$ compared with the same period in 1997, to South Korea declined by $24.5 \%$ and to ASEAN by $7.8 \%{ }^{6}$ Trade in services, such as tourism, declined as well. So too did the wages of Chinese workers in contracted projects in East Asia.

Second, because of reduced prices of exports of East Asian countries, the competitiveness of Chinese exports vis-à-vis exports from other parts of East Asia decreased in the third country markets. The structure of Chinese and other East Asian exports are similar, especially in commodities and some labour intensive products.

Third, China's inward FDI slowed significantly, FDI from East Asian countries having been a major source. In 1997, 70\% of China's total inward FDI was from East Asia. In 1997, China approved a total of 21,028 foreign-invested companies, a drop of $14.3 \%$ from 1996, with

\footnotetext{
${ }^{5}$ Xin Cao, "Yazhou Jinrong Weiji dui Zhongguo Jingji de Yingxiang jiqi Duice [Impacts of the Asian Financial Crisis on China's Economy and Its Countermeasures]," Lilun Shiye [Theoretical Horizon], no. 5 (1998). Also see Shaun Breslin, "The Politics of Chinese Trade and the Asian Financial Crises: Questioning the Wisdom of Export-led Growth," Third World Quarterly 20, no. 6 (1999).

${ }^{6} \mathrm{Cao}$, "Impacts on China's Economy and Its Countermeasures."
} 
the total amount of investment at US $\$ 51.76$ billion, a drop of $29.36 \%$ from $1996 .^{7}$ The production of some invested projects slowed down or was suspended.

Fourth, plans of overseas listing of Chinese SOEs were adversely affected by the more severe competition from regional governments in attracting foreign investments.

Hong Kong was heavily affected by the crisis. That was the background to Beijing's decision to establish the Closer Economic Partnership Arrangement (CEPA) with Hong Kong; in part this was to reduce the impact of depression, and also ensured political integration between Hong Kong and the mainland.

In response to the domestic criticism of the perceived irrationality of China's decision to maintain the value of the yuan at the current exchange rate, Wang Mengkui, Director of the Development Studies Centre of the State Council said that China kept the value of the yuan during the crisis not only for political objectives, but also because of five economic reasons. First, he argued, China's foreign reserve supply far exceeded the demand; moreover China ran substantial trade surpluses and still attracted much foreign investment. Second, long- and medium- term loans constituted the majority of China's foreign debts, and infrastructure projects constituted the majority of investment projects, so capital could not flee easily. Third, the yuan was not under pressure to be devalued because it was actually undervalued. Fourth, the devaluation of some Asian countries did significantly affect China's exports but devaluation of the yuan could not increase them by much. A devaluation would instead cause a new wave of regional currencies devaluation and economic fluctuation. Finally, keeping the yuan stable helped the stability of Hong Kong. ${ }^{8}$

\subsection{Political gains}

China gained a lot of political capital by keeping the value of the yuan stable during the crisis, although it was not the biggest donor of financial aid to crisis-hit countries. China stressed that had it devalued the yuan, international speculators would have attacked the foreign exchange and stock markets of other East Asian countries again. Chinese leaders, on various occasions, underlined China's friendship to its neighbours and sense of responsibility to the

\footnotetext{
${ }^{7}$ Ibid.

${ }^{8}$ Mengkui Wang, "Yazhou Jinrong Weiji yu Zhongguo [Asian Financial Crisis and China]," Qiushi [Seeking Truth] 1998.
} 
region, while indicating that some other countries were not 'real friends'. Chinese scholars think that although China was affected by the crisis, it dealt with it properly and resisted various pressures caused by the crisis, and became the bedrock for stabilising Asia Pacific economic development. They perceived that China's influence in the region and in the world was gradually rising as a highly responsible great power, and raised its status in a multi-polarising world. ${ }^{9}$ China argues that its contribution during the crisis showed that China was becoming a great global economic power, but it was under-represented at international financial institutions such as the World Bank, International Monetary Fund (IMF) and the Asian Development Bank (ADB). Former Ambassador Zhang Yijun at the Centre for International Affairs of the State Council said that some members of the American Congress started to think that China was a responsible state, though in fact China's position on Asia's stability had never changed. ${ }^{10}$ Beijing started to highlight its 'great power morality', which was to 'give more and take less' and shoulder collective responsibilities, similar to a benevolent hegemon in Western literature, and was in contrast to other great powers which had exploited the power imbalance for selfinterested purposes.

To signify their special political friendship and the importance that they attached to each other's peace and development, on 16 December 1997, China and ASEAN established the Partnership of Good Neighbourliness and Mutual Trust Oriented towards the 21st Century, the second highest level of diplomatic relationship of China's - only lower than a 'strategic partnership', which they announced in October 2003.

China did not miss the opportunity that the crisis provided to build up its political capital in the region at the expense of Japan and of the US. ${ }^{11}$ An old Chinese saying that the Chinese leaders often quoted when they talked about China's contribution to the region during the crisis was that "one knows the power of a horse when the way gets far; one knows the hearts of people when the time gets long," which implied that the sincerity of some countries failed the test of time while China passed the test. A Chinese scholar at the Central Party School judged

\footnotetext{
${ }^{9}$ Ibid.

${ }^{10}$ Yong Wang, "Causes, Impacts of the Asian Financial Crisis and China's Measures: A Summary of the Symposium "Asian Financial Crisis: Views from China and the US" Conference," Meiguo Yanjiu [American Studies], no. 3 (1998).

${ }^{11}$ Fengjun Chen, "Jinrong Weiji hou Yatai Geju de Bianhua [Changes in the Asia Pacific Structure after the Financial Crisis]," Guoji Zhengzhi Yanjiu [International Politics Studies], no. 2 (1999).
} 
that Japan's influence in the world and in the region significantly declined and that in the next several years, its second place in economic power in Asia Pacific would be challenged by new rising economic powers such as China. Other Chinese scholars judged that Japan could not be the leading 'goose' for East Asia anymore, and that ASEAN's reliance on Japan would certainly retreat because trust among Asia Pacific countries on Japan's ability to stabilize Asian economy had fallen. Some argued that Japan's subordination to the US fundamentally constrained its capacity to speak for or take care of the interests of Asia. ${ }^{12}$

Although some scholars thought that the US 'blunted' the aggressiveness of East Asian countries such as Japan and consolidated its leadership in Asia Pacific and world economy from the crisis, most scholars judged that the credibility of the US and of the US-led global financial institutions was doubted by Southeast Asian countries. ${ }^{13}$ In particular, they realized that the conditionalities of the IMF loans was criticized by ASEAN members not only because assessing whether the countries satisfied the conditionalities delayed the arrival of loans and the conditions compromised their sovereignty, but also because the spirit behind it - the Washington Consensus - was judged counter-productive to solving the problems peculiar to East Asia. ${ }^{14}$

\subsection{What lessons did China learn from the crisis?}

Perhaps the most important impact the Asian financial crisis had on China was ideational: by analyzing the causes of the crisis in other East Asian countries, China learned several lessons on domestic reform and international financial integration, which still direct its domestic and foreign policies today. ${ }^{15}$ Chinese scholars and government officials have written widely and largely have reached consensus on this, which can be summarized in the following four points. ${ }^{16}$

\footnotetext{
12 Ibid.

${ }^{13}$ For the former argument, see Ibid. Jian Tao and Fengying Chen, "Dongya Jinrong Weiji Baolu de Xin Wenti he Yinqi de Xin Bianhua [New Problems and Changes from East Asian Financial Crisis]," Shijie Jingji yu Zhengzhi [World Economy and Politics], no. 7 (1998). For the latter argument, see Xuebin Zhang, "Lun Zhong Mei Liangguo zai Yazhou Jinrong Weiji zhong de Biaoxian [The Performances of China and the US in the Asian Financial Crisis]," Guoji Zhengzhi Yanjiu [International Politics Studies], no. 2 (1999). Fan He, "Weiji zhihou de Yazou Huobi Hezuo [Asian Monetary Cooperation after Crisis]," Guoji Jingji Pinglun [International Economic Review], no. 1-2 (2001). Bin Zhang, "Yazhou Huobi Jijin de Fuhuo [The Revival of Asian Monetary Fund]," Dangdai Yatai [Contemporary Asia-Pacific Studies], no. 1 (2001).

${ }^{14}$ Tao and Chen, "New Problems and Changes." Zhang, "The Performances of China and the US."

${ }^{15}$ Breslin, "The Politics of Chinese Trade and the Asian Financial Crises."

${ }^{16}$ Bingmeng He, Rongcang Liu, and Shucheng Liu, Asian Financial Crisis: Latest Analysis and Measures
} 


\section{Sense of crisis}

First, a sense of crisis became deeply rooted among Chinese policymakers and scholars. The status of economic security, in particular financial security, has risen in the state's overall national security strategy. ${ }^{17}$ Although China, like other East Asian countries, has built up huge foreign reserves after the crisis in part as a safety valve against balance of payment problems, and Chinese policymakers and scholars feel that it is unlikely for a 1997-type crisis to recur to China, they are still wary of the problems inherent to China's economic system and the possibility of other types of crises happening to China. The Vice Secretary General of the Monetary Policy Committee of the People's Bank, Yi Gang, said that "the biggest influence of the crisis on China is that China realized a high possibility of itself having a financial crisis, and learned many lessons from ASEAN countries."

Chinese scholars shared a sense of crisis over the Chinese economy for several reasons:

First, China was entering a period of increasing domestic and international financial risk. It was becoming more difficult for China to attract foreign investments because of the uncertain domestic economic environment and the sudden decline of investments from overseas Chinese. Institutional reform was under pressure to match the speed and extent of marketization of other East Asian and Eastern European economies. ${ }^{19}$ Second, China's economic development model had been similar to that of other East Asian countries. China's economic structural adjustment was slow, exacerbated by redundant investment projects and over-supply of many goods. ${ }^{20}$ Third, the government's intervention in the market caused distortion in resource allocation, which had the potential to cause inflation and a bubble economy. Fourth, the citizens' savings and foreign capital were concentrated in banks, and then invested by the banks in industries that the government supports despite their high risk and high losses, which caused high debt rate of the enterprises and bad loans for the banks. And finally, China's financial institutions, the stock market and non-banking institutions were underdeveloped and had many problems. ${ }^{21}$

[Yazhou Jinrong Weiji: Zuixin Fenxi yu Duice] (Beijing: Social Sciences Literature Press, 1998).

${ }^{17}$ Tao and Chen, "New Problems and Changes."

${ }^{18}$ Chen, "Changes in the Asia Pacific Structure."

${ }^{19}$ Tao and Chen, "New Problems and Changes."

${ }^{20}$ Wang, "Asian Financial Crisis and China." Breslin, "The Politics of Chinese Trade and the Asian Financial Crises."

${ }^{21}$ Cao, "Impacts on China's Economy and Its Countermeasures." 


\section{Caution with liberalization}

Second, Chinese policymakers and scholars learned from the crisis that China should be cautious with financial liberalization. Chinese scholars point out that the fundamental reason for the crisis was the inconsistency between domestic reforms and the premature liberalization of the financial market. Therefore, it is widely held that developing countries should balance reform and liberalization, and that trade integration has more benefits for developing countries than financial integration. In particular, the liberalization of the financial sector should be coherent with the country's economic development and supervisory ability; it should be even more cautious in opening the capital market. ${ }^{22}$ They believe that China should conduct financial reform in a stable and active manner, and form a financial surveillance system. Moreover, they hold that the crisis did not happen to China despite problems with Chinese banks because China had capital controls, and that giving up capital controls should therefore be the last step of all marketization reforms, after domestic financial institutions have become strong enough to handle international risks and China has established the mechanism to monitor international capital flows, in particular the short-term ones, and it should be done only after floating the currency. ${ }^{23}$ The consensus in China has been that it should only gradually float the yuan because it is believed that the overall health of the national economy is heavily dependent on trade and domestic savings. In particular, Chinese scholars suggest that China should not allow international free capital - or 'hot money' - to enter or leave China freely, for instance by having restrictions on foreign loans of domestic companies and local governments, and that Chinese banks should not allow loans that are not certain to be returned in the future. ${ }^{24}$

\footnotetext{
${ }^{22}$ Wang, "Asian Financial Crisis and China." Qi Xiao, "Ziben Xiangmu Kaifang yu Jinrong Anquan [Capital Account Liberalization and Financial Security]," Jinrong Jiaoxue yu Yanjiu [Finance Education and Studies], no. 3 (2006). Shaun Breslin, "Paradigm Shifts and Time-lags? The Politics of Financial Reform in the People's Republic of China," Asian Business \& Management 2 (2003).

${ }^{23}$ Yongding Yu, "Yazhou Jinrong Weiji 10 Zhounian he Zhongguo Jingii [10th Anniversary of Asian Financial Crisis and Chinese Economy]," Guoji Jinrong Yanjiu [International Financial Studies], no. 8 (2007).

${ }^{24}$ Gang Fan, "Quanqiuhua zhong de Bupingdeng Wenti: Yazhou Jinrong Weiji de Jiaoxun ji Zhengce Hanyi [Inequality in Globalization: Lessons from Asian Financial Crisis and Policy Implications]," Guoji Jingji Pinglun [International Economic Review], no. 3 (1999). Another famous Chinese economist, Wei Zhong, cautions that the amount of hot money in China has surpassed that in East Asia before the Asian financial crisis, while the GDP of China is only one quarter of the total GDP of pre-crisis ASEAN, Japan and South Korea. Wei Zhong, "1 3 niannei, Naxie Yinsu Keneng Yingxiang Woguo Jinrong Wending [Within 1-3 Years, Which Factors May Affect China's Financial Stability]," Diyi Caijing Ribao [First Finance Daily], 5 May 2008.
} 
Importantly, Chinese scholars criticize the Washington Consensus - with liberal economics at the centre - regarding economic reform and liberalization as being not necessarily safe or helpful to East Asian economies, and they hold that China should use discretion when it listens to the advice of the IMF. The reason, they argue, is that privatisation and liberalization cannot prevent financial crises but may aggravate or even cause them if not companied by comprehensive regulation and supervision. Ding Ningning at the Development Studies Centre of the State Council points out that financial internationalization and electronification have not increased the transparency of the international market but have exacerbated its instability. ${ }^{25}$ Scholars from the CASS also argue that the outward orientation is not a prescription for all problems of economic growth and development because over-reliance on export and foreign investment may render the country vulnerable to external risks and to foreign speculation or control. They hold that a country should instead stimulate domestic demand, enhance industrial competitiveness by investing in technology, and construct a sound regulation system.

\section{Necessity of domestic reform}

Third, Chinese scholars conclude from the crisis that developing countries should accelerate domestic institutional reform because it is necessary for them not to be marginalized in the power-politics world during the inevitable trend of globalization. ${ }^{26}$ They point out that bubbles are easily formed in the existing domestic system, especially in the financial and real estate markets, and China's existing financial institutions are not strong enough to deal with risks in China's gradual integration into the world economy. Therefore, they believe that bank reforms and other institutional reforms need to be continued so that China will be able to prevent economic overheating and to strengthen supervision over international capital flows. In Steinfeld's view, the Asian financial crisis helped the formation of an ideational environment in China that enabled members of the Chinese policy elite like Premier Zhu Rongji to push forward more radical and fundamental market reforms. As a result, China's agenda of 'reform as the salvation of socialism' became replaced by 'markets as the salvation of growth and

\footnotetext{
${ }^{25}$ Wang, "Views from China and the US."

${ }^{26}$ Fan, "Lessons and Policy Implications."
} 
legitimacy'. ${ }^{27}$ At the same time, as discussed above, Chinese policymakers and scholars became more vigilant of the pitfalls in economic liberalization. They hold mixed views on the relationship between China's domestic reform and international liberalization; as Steinfeld agrees, many increasingly prioritize domestic development over opening. ${ }^{28}$

\section{Necessity of regional cooperation}

Finally, like those in other East Asian countries, Chinese policymakers and scholars became convinced that regional cooperation was needed to prevent crises from happening again in East Asia, and to increase the region's voice in international financial arenas. ${ }^{29}$ Chinese scholars argue that because the prevention and rescue of financial crises are a regional public good although with global aspects, regional members may act in a more responsive and responsible way than countries from outside the region; therefore, regional institutions and mechanisms may be more effective than global institutions in preventing crises. In October 1998, at the Annual Meeting of the World Bank and IMF, Governor of China's central bank, Dai Xianglong, said that "the main cause of the crisis [was] that international cooperation and the evolution of the international financial system lag[ged] far behind economic globalization and the financial integration process. ${ }^{30}$

Existing regional organizations such as ASEAN and APEC did not stop the Asian financial crisis effectively because of the lack of mechanisms for strategic economic cooperation and of strong leadership in those organizations. ${ }^{31}$ Some think that the 'Asian Values' that stress informality and consensus are not suitable for regional monetary cooperation, which requires countries to surrender part of state sovereignty in monetary policy and in some domestic economic policies. ${ }^{32}$ The Chinese president Jiang Zemin said at the $5^{\text {th }}$ APEC Forum on 27 November 1997 that "[w]e hold a positive attitude towards strengthening Asian financial cooperation, and are willing to participate in the discussion on mechanisms for such

\footnotetext{
${ }^{27}$ Edward Steinfeld, "Embrace of Capitalism: China Ten Years after the Asian Financial Crisis," in Crisis as Catalyst: Asia's Dynamic Political Economy, ed. Andrew Macintyre, T.J. Pempel, and John Ravenhill (Ithaca: Cornell University Press, 2008).

${ }^{28} \mathrm{He}$, "Asian Monetary Cooperation after Crisis."

${ }^{29}$ Xiao, "Capital Account Liberalization."

30 "Statement by Dai Xianglong," 6-8 Oct. 1998.

${ }^{31}$ Tao and Chen, "New Problems and Changes."

${ }^{32} \mathrm{He}$, "Asian Monetary Cooperation after Crisis."
} 
cooperation," and again at the East Asian Leaders' Informal Meeting on 15 December that "currently it is necessary to further strengthen East Asian financial cooperation."

\section{Asian Monetary Fund}

At the annual meetings of the World Bank and IMF in September 1997, the Japanese Vice Minister of Finance Eisuke Sakakibara tabled the idea of an Asian Monetary Fund (AMF) to help crisis-hit countries. The AMF was envisioned as a USD100 billion fund composed of ten members China, Hong Kong, Japan, South Korea, Australia, Indonesia, Malaysia, Singapore, Thailand and the Philippines, with the notable exclusion of the US. The original memo suggested that the AMF would not necessarily act in unison with the IMF ${ }^{33}$ Proposed major donors would be Japan for $\$ 50$ billion and other countries for the other $\$ 50$ billion. Although "[the AMF] received a warm reception in virtually every Southeast Asian capital" and South Korea were favourably disposed, support began fading immediately as the US and IMF expressed opposition. ${ }^{34}$

Some studies hold that Japan's proposal was a deliberate move by the state, although they differ as to whether Japan was trying to defend the Japan-led Asian model of economic development against the US-led neoliberal economic model, or simply to assume East Asian regional leadership by seizing the opportunity to exclude the US. ${ }^{35}$ Others point out that it was more from idiosyncratic personalities, in this case, Sakakibara, and the proposal could not represent the opinions of other actors in Japan such as the Bank of Japan or the Financial Supervisory Agency, or even the important department of the Ministry of Finance. ${ }^{36}$ In China, there was little public or academic discussion on the AMF immediately after it was proposed. Existing literature shows that later analyses by Chinese scholars all regarded the AMF proposal as a state behaviour by Japan, born from deliberate considerations. There were two views

\footnotetext{
${ }^{33}$ Eisuke Sakakibara, Nihon to Sekai ga Furueta Hi [The Day that Rocked Japan and the World] (Tokyo: Chuo Koron Shinsha, 2000), 183-4, quoted in Phillip Y. Lipscy, "Japan's Asian Monetary Fund Proposal," Stanford Journal of East Asian Affairs 3, no. 1 (Spring 2003).

${ }^{34}$ Eric Altbach, "The Asian Monetary Fund Proposal: A Case Study of Japanese Regional Leadership," Japan Economic Institute Report No. 47a (19 December 1997).

${ }^{35}$ Yong Wook Lee, "Japan and the Asian Monetary Fund: An Identity-Intention Approach," International Studies Quarterly 50 (2006). Lipscy, "Japan's Asian Monetary Fund Proposal."

${ }^{36}$ Werner Pascha, "The Role of Regional Financial Arrangements and Monetary Integration in East Asia and Europe in Relations with the United States," The Pacific Review 20, no. 3 (September 2007).
} 
among Chinese academics. The first view was that Japan's initiative to set up an AMF was to strengthen its economic power, to internationalize the yen and to consolidate economic leadership in Asia; therefore China should be cautious. ${ }^{37}$ The second view was that AMF would be an important venue for China to have more influence in international economic and financial institutions and to promote world multi-polarization; therefore China should participate actively. ${ }^{38}$ As will be discussed later, at the time of the proposal of the AMF, the first view prevailed in the policymaking circle mainly because the Ministry of Foreign Affairs, which did not have political trust for Japan, played a crucial role in China's policymaking on financial regionalism.

When Japan formally proposed the AMF at the Regional Finance Ministers' Meeting in Hong Kong on 21 November 1997, which the US and IMF attended as observers, ASEAN countries and South Korea expressed support for the AMF proposal, Hong Kong and Australia remained neutral, and China voiced no opinion. ${ }^{39}$

Some suspect that the silence of China on this issue was caused by the lack of capacity of Chinese representatives to respond quickly to emergent issues, which reflected the limited autonomy of Chinese representatives as well as the slow decision of the Chinese bureaucracy, in particular to respond to a new idea that suddenly emerged in its international economic relations. ${ }^{40}$ That is partly true - when the AMF idea was informally floated before the Hong Kong Meeting, ${ }^{41}$ according to an interviewee at the Ministry of Finance (MOF), the Chinese government held a 'wait-and-see' attitude because on the one hand, the government thought that the Chinese economy would not be hit by crisis or threatened with such a danger, and on the

\footnotetext{
${ }^{37}$ Le Lin and Zheng Gong, "Guanyu Yazhou Huobi Jijin Youxiaoxing de Fenxi [An Analysis of the Effectiveness of the AMF]," Guoji Jinrong Yanjiu [International Financial Studies], no. 8 (2001).

${ }^{38}$ Zixian Wang, "Ouyuan yu Dongya Jinrong Hezuo [Euro and East Asian Financial Cooperation]," Shijie Jingji [World Economy], no. 3 2000). Weijun Wang, "Yazhou Huobi Jijin de Youlai ji Qianzhan [The Background and Prospects of the Asian Monetary Fund]," Xin Jinrong [New Finance], no. 9 (2001). Pinghai Li, "Yazhou Quyu Jinrong Hezuo zhong de Riben yu Zhongguo [Japan and China in Asian Regional Financial Cooperation]," Riben Xuekan [The Japan Journal], no. 2 (2006).

${ }^{39}$ See for example Jennifer Amyx, "Moving Beyond Bilateralism? Japan and the Asian Monetary Fund," Pacific Economic Paper, Australia-Japan Research Centre, Australian National University, no. 331 (2002). Lipscy, "Japan's Asian Monetary Fund Proposal."

${ }^{40}$ The lack of autonomy of Chinese representatives at international financial organizations has been documented by Ann E. Kent, Beyond Compliance: China, International organizations, and Global Security, Studies in Asian security (Stanford, Calif.: Stanford University Press, 2007), 132-33.

${ }^{41}$ Lee, "Japan and AMF."
} 
other hand, China was watching the response of the US. ${ }^{42}$ At that time, China viewed Sino-US relationship important for its stable external environment for domestic economic development, and the US was the most important negotiating party in China's WTO accession. During the worst time of the crisis, two talks between Jiang Zemin and Bill Clinton improved Sino-US relations to their best in the post- 1945 period, and the two countries vowed to establish a 'constructive strategic partnership' ${ }^{43}$ Therefore Beijing tried to predict Washington's attitude and believed that the US had much influence on the region especially on Japan and doubted if it would support the AMF proposal. ${ }^{44}$ The opposition of the IMF made China more doubtful of the proposal, because Chinese policymakers thought that the IMF was dominated by and represented the opinion of the US. In fact, the US lobbied China to oppose the plan by emphasizing the threat of 'Japanese hegemony'. ${ }^{45}$ Therefore, when the US and IMF expressed objections against the AMF proposal, China kept silent.

At the same time, sources confirm that when Japan informally flagged the AMF idea, China did have some 'contention' over this idea. ${ }^{46}$ It is said that at the Pacific Economic Cooperation Council (PECC) Congressional Meeting in Seattle in 1997, the national committees of Japan, the Philippines and Taiwan together raised the idea of an AMF. The Chief and Vice Representatives of the Chinese Committee, Guo Jiading and Yang Chengxu, invited a Chinese economist, Huang Weiping, from the financial discussion group to the congress to give his opinion. Huang thought that the AMF idea was not meaningful or mature enough to be discussed. He questioned what principles [of conditionality] the proposed AMF would have: IMF plus (stricter than IMF conditionality), IMF minus or IMF based [equal]? He contended that if it would be IMF plus, the Asian countries would not be able to receive loans because they could not get them from the IMF anyway; if it would be IMF minus, the conditionality might be too loose and create moral hazard problems; if it would equal IMF conditionality, it was not

\footnotetext{
${ }^{42}$ Interview with an MOF official, Beijing, March 2006.

${ }^{43}$ Chen, "Changes in the Asia Pacific Structure."

${ }^{44}$ Interviews with an MOF official, and with a scholar at CASS, March 2006, Beijing.

${ }^{45}$ Lipscy, "Japan's Asian Monetary Fund Proposal."

${ }^{46}$ Yunling Zhang and Bin Zhang, "Dongya Jinrong Hezuo de Jinzhan yu Weilai de Xuanze [Progress in Asian Financial Cooperation and Future Choices]," Dangdai Yatai [Contemporary Asia Pacific], no. 8 (2002).
} 
necessary to have another institution just on a smaller scale. According to Huang, the three proposing parties could not answer his questions. ${ }^{47}$

More importantly, however, as some scholars observed: "although the debate over the AMF seemingly revolves around questions of economic efficiency, motivations and outcomes are largely driven by political concerns. ${ }^{, 48}$ In Beijing, the government invited some Chinese scholars to a meeting to discuss how to respond to Japan's AMF proposal. At the meeting, a scholar suggested that China should support the establishment of an AMF and should participate actively in it so that China could enjoy many benefits as a founding member. In response, an MFA official voiced his objection immediately: "First, we should oppose Japan's lead [that is, any initiative of Japan's]; second, we should prevent Taiwan from expanding international space through this opportunity." ${ }^{49}$ His words expressed two of the major objectives of China's regional strategic objectives at that time - to reduce Japan's influence and to marginalize Taiwan. In particular, opposition to any of Japan's initiatives embodied a deeply-rooted mistrust of the Chinese foreign policy apparatus for Japan's political intentions. Besides, the Chinese government did not want Japan to make an early move in regional cooperation and institutionalize its power when Japan's economic power was stronger than China's. As will be discussed later, China's political mistrust for Japan still echoes strongly in China's current foreign economic policy. An important reason for this is that the Ministry of Foreign Affairs played a leading role in initiating or endorsing policy proposals, especially in China's early years of international economic cooperation, which was regarded as part of economic diplomacy, although this role of 'assessing political qualification' may be less significant vis-àvis ministries of economic affairs in cases where economic expertise is most needed, for instance, in deciding the specific forms of FTAs and financial arrangements.

Because the above political and strategic thinking held by the Ministry of Foreign Affairs dominated the policymaking, the Chinese State Council did not approve the AMF proposal, ${ }^{50}$

\footnotetext{
${ }^{47}$ Interview with Huang Weiping, Beijing, February 2006.

${ }^{48}$ Lipscy, "Japan's Asian Monetary Fund Proposal."

${ }^{49}$ Interview with the above-mentioned scholar, Beijing, April 2007.

${ }^{50}$ Interview with an official at the People's Bank, Beijing, March 2006.
} 
and China did not support the AMF proposal at the international arena when it was formally put forward.

As a result, the AMF proposal was effectively 'dead' in the face of grave US opposition and without China's support. In its place came the 'Manila Framework', which has no institutional component or the regional orientation of the $\mathrm{AMF}$ and is designed rather to enhance the role of the IMF in Asia. ${ }^{51}$ Although unsuccessful, the AMF proposal was widely seen as an important precursor of East Asian financial cooperation both among East Asian countries and among Chinese academics. Some observers even call the Chiang Mai Initiative in 2000 and its later developments a 'revival' of the $\mathrm{AMF}^{52}$

\section{The Chiang Mai Initiative}

The Chiang Mai Initiative (CMI) is an important step in East Asian financial cooperation because it is widely regarded as the first concrete arrangement of economic cooperation among ASEAN Plus Three countries (ASEAN, China, Japan, South Korea), and it might serve as a foundation for full-fledged regional financial cooperation. ${ }^{53}$ At the sideline of the annual meeting of the board of governors of the ADB, the ASEAN +3 finance ministers announced their plan to cooperate in four areas: monitoring capital flows, regional surveillance, swap arrangements, and personnel training. Among them, the 'Chiang Mai Initiative' usually refers to the agreement to establish a network of bilateral swap arrangements (BSA) among the 13

\footnotetext{
${ }^{51}$ In preparation for APEC Summit meeting, senior finance officials of APEC met in Manila on November 18-19 and developed a framework for dealing with financial crises in the region. This Manila Framework was endorsed by the eighteen leaders of the economies of APEC at the forum's annual summit in Vancouver, BC, on November 25, 1997. The Manila Framework recognized that the role of the IMF would remain central and included enhanced regional surveillance, intensified economic and technical cooperation to improve domestic financial systems regulatory capacities, adoption of new IMF mechanisms on appropriate terms in support of strong adjustment programs, and a cooperative financing arrangement to supplement, when necessary IMF resources. APEC 1997 Leaders Declaration, November $25,1997$.

${ }^{52}$ Zhang, "The Revival of AMF." Yung Chul Park and Yunjong Wang, "The Chiang Mai Initiative and Beyond," The World Economy 28, no. 1 (January 2005).

${ }^{53}$ Douglas Weber, "Two Funerals and a Wedding? The Ups and Downs of Regionalism in East Asia and Asia-Pacific after the Asian Crisis," The Pacific Review 14, no. 3 (2001). Sanae Suzuki, "Chairmanship in ASEAN+3: A Shared Rule of Behavior," Japan Institute of Developing Economies Discussion Paper, no. 9 (October 2004).
} 
countries to provide short-term liquidity assistance in the form of swaps of US dollars with the domestic currencies of participating countries. ${ }^{54}$

In order to strengthen our self-help and support mechanisms in East Asia through the ASEAN + 3 framework, we recognized a need to establish a regional financing arrangement to supplement the existing international facilities. As a start, we agreed to strengthen the existing cooperative frameworks among our monetary authorities through the "Chiang Mai Initiative". The Initiative involves an expanded ASEAN Swap Arrangement that would include all ASEAN countries, and a network of bilateral swap and repurchase agreement facilities among ASEAN countries, China, Japan and the Republic of Korea. ${ }^{55}$

After the meeting in Chiang Mai, the deputies and working-level officials from the central banks and finance ministries met on numerous occasions to discuss specific measures of expanding the ASEAN Swap Arrangement and introducing a set of BSAs. In addition, officials added a set of repurchase arrangements to the CMI. Since then, the CMI has not only expanded in the volume of funding but also strengthened mechanisms for surveillance and for activation, as will be discussed in the next section.

Although China did not support the AMF proposal, China's stance on regional financial cooperation shifted around 1999 to become an active supporter of regional financial cooperation. ${ }^{56}$ The Chinese Finance Minister, Xiang Huaicheng, announced the Chinese government's support for the CMI in January $2001 .{ }^{57}$ Why did China not support the AMF proposal but supported the CMI? I will provide answers from the following six aspects: the ownership of the initiative; the more accommodating attitude of the US and the IMF; the shift in China's diplomatic strategy; the increased regional pressure on China; China's enhanced awareness of financial security; and, the symbolic and flexible nature of the CMI arrangements.

\footnotetext{
54 The one exception was the Japan-China BSA, which would swap yen for yuan, although more arrangements were made later in local currencies such as those between China and the Philippines, and China and Korea.

55 "The Joint Ministerial Statement of the ASEAN+3 Finance Ministers Meeting," 6 May 2000, Chiang Mai, Thailand, available online at http://www.aseansec.org/635.htm.

${ }^{56}$ Tadahiro Asami, "Chiang Mai Initiative as the Foundation of Financial Stability in East Asia", Institute for International Monetary Affairs, Japan, 1 March 2005, www.aseansec.org/17905.pdf.

57 "Speech on Regional Financial Cooperation by H.E. Xiang Huaicheng", Kobe, Japan, 14 January 2001, http://www.fmprc.gov.cn/eng/wjb/zzjg/gjs/gjzzyhy/2604/2606/t15282.htm.
} 
As will be discussed in more detail, although strategic considerations held by central

government ministries, in particular the MFA, were still crucial in China's attitude towards the CMI, international dialogue — both Track One discussions among governments and Track Two discussions among scholars - at the regional level created a congenial discursive environment that added pressure on China to cooperate. At the same time, economic considerations from MOF and the central bank became more prominent in deciding the 'depth' of China's cooperation because China must ensure that the domestic financial system would be able to cope with potential risks brought about by regional arrangements.

\subsection{The ownership of the initiative}

As discussed previously, China's preliminary assessment of a proposal for international cooperation is a political assessment of the potential partner country, conducted by the MFA. China opposed Japan's AMF proposal mainly because the MFA had suspicion of Japan's political intentions. On the strategic front, it seems that China was more willing to accommodate ASEAN's proposals and certainly would like its own initiatives to be realized and appreciated by other regional members, in particular by ASEAN.

According to a Chinese scholar, the CMI was proposed at the PECC Seattle Meeting in 1997. The Financial Discussion Group pondered on the idea of settling debts among Asian countries without converting to the US dollar, and the bilateral swap arrangement was the result of the discussion.

The dominant view, however, suggests that the origin of CMI dates back to the ASEAN Swap Arrangement, which was established among five ASEAN members (Indonesia, Malaysia, the Philippines, Singapore and Thailand) in 1977. Its purpose was to provide short-term, immediate swap facilities to any member facing a temporary liquidity shortage or balance of payment problem. $^{58}$

\footnotetext{
${ }^{58}$ Haihong Gao, "Cong Qingmai Changyi dao Yazhou Zhaiquan Jijin [From Chiang Mai Initiative to Asian Bond Fund]," Guoji Jingji Pinglun [International Economic Review], no. 3 (2004), C. Randall Henning, East Asian Financial Cooperation, Policy Analyses in International Economics (Washington DC: Institute for International Economics, 2002).
} 
Some Chinese scholars say that CMI was proposed by Japan. ${ }^{59}$ However, according to

Chinese policymakers and scholars who are closely involved in regional financial dialogues, the initial suggestion was from both Japan and Korea, but their proposed bilateral swap arrangement was only among Japan, Korea and China. It was under the advocacy of China that this swap network was expanded to include all ASEAN +3 countries. ${ }^{60}$

China's initiative to include ASEAN into the bilateral swap arrangement is understandable because ASEAN was the most important target of China's 'good neighbourly' diplomacy, and the diplomatic strategy designed by Chinese foreign policy makers was to exert its influence on regional matters from behind ASEAN so as not to appear threatening. Besides, when Japan proposed an ASEAN+Japan Framework of cooperation, the Malaysian Prime Minister Mahathir Mohamad proposed a counter-plan of ASEAN+3, and insisted that China should be involved. ${ }^{61}$ Moreover, the CMI was a result of the ASEAN+3 Finance Ministers Meetings, which developed on the basis of the ASEAN+3 Dialogue of Finance and Central Bank Deputies; and the latter was established under China's initiative in March 1998 and launched under the auspices of ASEAN.

It is worth mentioning China's view on Japan's New Miyazawa Initiative ${ }^{62}$ China pointed out that Japan's aggressiveness to use financial advantage to assume regional leadership was obvious and the Initiative was carried out with the support of the US and the IMF. At the same time, China realized that this Initiative was welcomed by Southeast Asian countries, and that Japan's influence in East Asia increased. ${ }^{63}$ That may have been an incentive for China to take a

\footnotetext{
${ }^{59}$ Wang, "Yazhou Huobi Jijin de Youlai ji Qianzhan [The Background and Prospects of the Asian Monetary Fund]."

${ }^{60} \mathrm{Gao}$, "From CMI to ABF."

${ }^{61}$ Kent, Beyond Compliance, Lee, "Japan and AMF.", David P. Rapkin, "The United States, Japan, and the Power to Block: The APEC and AMF Cases," The Pacific Review 14, no. 3 (2001), Suzuki, "Chairmanship in ASEAN+3.", Weber, "Two Funerals and a Wedding?.", Xiao, "Capital Account Liberalization.", Zhang and Zhang, "Dongya Jinrong Hezuo de Jinzhan yu Weilai de Xuanze [Progress in Asian Financial Cooperation and Future Choices]."

${ }^{62}$ In 1998 when the effects of the Asian Financial Crisis expanded to other parts in the world like Russia and Latin America as well as the US, and posed a threat to global financial stability, on 3 October 1998 Japan proposed the New Miyazawa Initiative to provide assistance to crisis-hit East Asian countries, namely South Korea, Indonesia, Malaysia, Thailand and the Philippines. Under this Initiative, Japan proposed to provide a package of support measures totalling US\$30 billion, of which US\$15 billion will be made available for the medium- to long-term financial needs for economic recovery in Asian countries, and another US\$15 billion will be set aside for their possible short-term capital needs during the process of implementing economic reform. The funding was mainly provided by IMF, ADB and the World Bank and was distributed by Japan to those countries.

${ }^{63}$ Jie Sun, "Shenhua Yazhou Jinrong Hezuo de Tujing: Riben de Zuoyong he Yingxiang [Ways to Deepen
} 
more proactive role in regional cooperation starting from 1999. In fact, as will be discussed later, China continues to be generally obstructive to Japanese proposals of regional economic cooperation, and has sought to take ownership of initiatives of regional economic cooperation that it deems plausible.

\subsection{Views of the US and the IMF}

One view suggests that China became more supportive of East Asian financial cooperation because China's objective to hedge against the US in the region had overtaken that to hedge against Japan. ${ }^{64}$ It may be true that hedging against both Japan and the US were important objectives of China's regional diplomacy, but in 1999, China was still in WTO accession negotiations with the US and therefore Beijing was trying hard to enhance its relations with Washington. In fact, during the negotiations over the basic modalities of the swap arrangements, China "stood firm in its insistence that the arrangements be closely linked to IMF programs and argued for 100 percent linkage. ${ }^{365}$ A close linkage with the IMF would not only minimise the risk for China as a potential donor, but also make the CMI less provocative to the US than the AMF was. Although some Chinese scholars argue that American opposition towards the economic and financial arrangements of other regions seems to have not worked, ${ }^{66}$ the views of the US and the IMF do seem to have remained important to East Asian countries. From its launch in 2000 , it was made clear that the CMI was intended to 'supplement the existing international facilities'. The status of 'supplementation' of the CMI to existing international financial arrangements has been reiterated at every ASEAN +3 Finance Ministers Meeting since 2005 .

The decreased sensitivity of the US and the IMF over East Asian financial cooperation opened a window for East Asian countries, including China, to be more articulate in their pursuit of financial regionalism. The US had reduced its sensitivity regarding Asian initiatives because of its involvement in other parts of the world. ${ }^{67}$ Whereas the US Department of

\footnotetext{
Asian Financial Cooperation: Japan's Role and Influence]," Shijie Jingji yu Zhengzhi [World Economy and Politics], no. 5 (2007).

${ }^{64}$ Rapkin, "The APEC and AMF Cases."

${ }^{65}$ Jennifer Amyx, "What Motivates Regional Financial Cooperation in East Asia Today?," Asia-Pacific Issues Paper, East-West Center, no. 76 (March 2005).

${ }^{66}$ Wang, "Euro and East Asian Financial Cooperation."

${ }^{67}$ Henning, however, points out that "notwithstanding statements of neutrality, many Western officials
} 
Treasury had been principally responsible for the rejection of the AMF proposal in 1997, it took a softer line in 2000.The Assistant Secretary for International Affairs, Edwin M. Truman, who represented Treasury at the $\mathrm{ADB}$ meeting when the $\mathrm{CMI}$ was proposed, said that regional initiatives such as these could well be constructive in principle and that greater cooperation among Asian countries was "perfectly appropriate." At the same time, Truman cautioned that "[t]he devil is in the details." Deputy Secretary of State of the US, Richard Armitage, said on 17 August 2001 that regional speculation about an eventual Asian Monetary Fund to confront economic crises like the 1997-98 meltdown "doesn't seem to me to be a bad idea". ${ }^{68}$

The IMF also lent its cautious support for the CMI, noting that Asians had stated their intention to work with the IMF, since the IMF did not have enough funds. ${ }^{69}$ On 1 June 2000, upon the first stop of his five-country visit to Asia, the IMF Managing Director Horst Kohler expressed his support for the Chiang Mai Initiative on the basis that it was complementary to the work of the IMF. On the same day, the First Deputy Managing Director of the IMF, Stanley Fischer, made a similar comment that the CMI could make useful contribution to the regional members' access to external sources of foreign reserves when they needed them to cover shortterm debt. ${ }^{70}$

\subsection{Shift in China's grand diplomatic strategy}

China's grand diplomatic strategy has important implications for policies on international economic cooperation because the latter is often referred to by the Chinese government as 'economic diplomacy'. ${ }^{71}$ As mentioned in Chapter Three, China's diplomatic strategy became

and academics harbour an abiding scepticism about financial arrangements in the region. Official support in the West for more robust regional arrangements cannot be taken for granted." Henning, East Asian Financial Cooperation, 3.

68"Asian Monetary Fund Not a Bad Idea Says US Official," Central Banking Publications, 22 Aug. 2001.

${ }^{69}$ Arran Scott and James T. Areddy, "US, IMF Cautiously Welcome Asia Currency Swap Plan," Dow Jones International News, 8 May 2000. C. Randall Henning, East Asian Financial Cooperation, vol. 68, Policy Analyses in International Economics (Washington D.C.: Institute for International Economics, 2002). Asami, "CMI as Foundation of Financial Stability." Stuart Harris, “Asian Multilateral Institutions and Their Response to the Asian Economic Crisis: The Regional and Global Implications," Pacific Review 13, 3 (2000): 495-516. Ross Garnaut and Dominic Wilson, "The East Asian Financial Crisis: Regional and Global Responses," in Private Capital Flows in the Age of Globalization edited by Uri Dadush, Dipak Dasgupta and Marc Uzan (Edward Elgar, 2000): 63-80.

70 "Asia and the IMF" Remarks by Stanley Fischer, First Deputy Managing Director of the International Monetary Fund at the Singapore Policy Institute, 1 June 2001,

http://www.imf.org/external/np/speeches/2001/060101.htm.

${ }^{71}$ At a press conference of the First Session of the 11 th National People's Congress in March 2008, the Chinese Foreign Minister Yang Jiechi explained the connotations of economic diplomacy: first, to deepen strategic and political mutual trust between China and other countries, and to create a good environment 
more proactive since 1999, particularly in East Asia. One incentive was to alleviate ASEAN's worry over China's economic threat upon its imminent entry into the WTO, and another was to compete with Japan's increased influence in East Asia because of the latter's New Miyazawa Initiative and other initiatives to form regional institutions. Despite Deng Xiaoping's guidance for Chinese diplomacy to 'tao guang yang hui' [hide the sharpness and accumulate strength], Chinese foreign policymakers judged that it was time for China to follow the trend of time and be more proactive. Moreover, the Chinese government would like to spend the political capital that it accumulated from the Asian financial crisis for political or economic returns. As for the imbalance of power between China and Japan, some Chinese scholars argued that China's overall economic and financial power would catch up with or exceed Japan's in the next 10 to 20 years, which needed to be matched with an enhanced role in regional affairs so as to protect China's national interest, and that China could utilize the conflicts between Japan and other East Asian countries and adopt a strategy of both fighting and cooperation. Besides, "We should support Asian financial cooperation because, apart from the above reasons, China can challenge the existing international financial institutions including the IMF, which is controlled by the US, and expand China's influence in international financial affairs."

Apart from its proposal of the China-ASEAN Free Trade Agreement in 1999, China became more active in taking the initiative in regional financial cooperation, which can be seen in the following cases:

At the second ASEAN+3 Summit in Hanoi, China proposed the ASEAN+3 Dialogue of Finance and Central Bank Deputies, which was launched under the auspices of ASEAN in March 1998. To deepen this dialogue mechanism, China suggested three further proposals: to institutionalize the Dialogue, and convene meetings of finance ministers and central bank governors; to share information and experience on financial reforms and set up an ad hoc committee for an in-depth study of the supervision and regulation of international capital flow

and atmosphere for international economic cooperation; second, to propel multilateral and bilateral free trade cooperation and resolve economic disputes through dialogue; and third, to support the realization of important cooperation projects and to protect legal rights of overseas Chinese citizens and companies.

"Yang Jiechi tan jingji waijiao he gongzhong waijiao [Yang Jiechi Talks about Economic Diplomacy and Public Diplomacy]", Xinhua Net News, 12 March 2008, available online at

http://news.xinhuanet.com/misc/2008-03/12/content 7772542.htm

${ }^{72}$ Wang, "Euro and East Asian Financial Cooperation." 
and the restructuring of the international financial system; and to coordinate the positions of East Asian countries on major international financial and economic issues through this mechanism "so that East Asia may do its part for the reform of the international financial system." ${ }^{73}$

Besides, China has taken the responsibility for providing training courses on Economic Reforms and Development and on the regional economic and financial cooperation for ASEAN +3 finance and central bank officials in Beijing since 2000. It shows that the Chinese government has realized the importance of gaining international influence through influencing the minds of future elites and building a wide personal network.

Moreover, when the ASEAN+3 Finance Ministers decided to undertake more studies on regional financial cooperation at their Meeting in 2004, China, as well as Japan, offered to provide financial assistance for those studies. ${ }^{74}$ As expert opinion has been an important input into regional policies on financial cooperation, and it used to be dominated by Japan, China wanted to play a more central role in second-track dialogues so as to indirectly influence firsttrack policy decision.

\subsection{Regional pressure}

The AMF idea was informally floated at the start of the crisis, and was formally proposed in the middle of the crisis; therefore many countries were still busy fighting the crisis and trying to acquire help from other countries or from the IMF through bilateral channels. By 1999, however, the dust of the crisis had more or less settled, resentment among East Asian countries against IMF conditionality had grown as they reflected upon the events of the previous years, Europe launched the Euro and North America furthered developed the NAFTA and even started to discuss its own dollar zone, discussions in East Asia on forming its own regionalism and on strengthening regional self-help to prevent and manage crises gained momentum. ${ }^{75}$ The annual ASEAN+3 Summit started in 1998, and at their second meeting in November 1999 in Manila,

\footnotetext{
73 "Chinese Premier Urges Greater Regional Cooperation at Recent ASEAN Summit," Xinhua News Agency, 28 Nov. 1999.

74 "The Joint Ministerial Statement of the ASEAN+3 Finance Ministers Meeting," 15 May 2004, Jeju, South Korea.

${ }^{75}$ Interviews. Also see Wang, "Euro and East Asian Financial Cooperation." Yongding Yu, Fan He, and Jing Li, "Yazhou Jinrong Hezuo: Beijing, Zuixin Jinzhan yu Fazhan Qianjing [Asian Financial Cooperation: Background, Progress and Prospects]," Guoji Jinrong Yanjiu [International Financial Studies], no. 2 (2002).
} 
leaders of member countries issued their first Joint Statement, calling to enhance self-help and support mechanisms through the ASEAN+3 Framework. ${ }^{76}$ They called upon the region's finance ministers to produce something tangible when they met the following year. ${ }^{77}$ Discussions on strengthening East Asian cooperation were also held at various regional forums like the Executives' Meeting of East Asia and Pacific Central Banks (EMEAP), forums organized by the ADB, the Asia-Europe Meeting (ASEM) and ASEAN. Track Two dialogues became an important channel for exchanging ideas and research findings among scholars. Despite some of these scholars' close association with the governments, they hoped for progress in regional financial cooperation and helped create a positive discursive environment, which arguably influenced the policies of national governments including that of China.

The pressure from East Asian countries, especially ASEAN, on China to take a more active role in regional financial cooperation also increased after the AMF proposal. According to a MOFTEC official, when Malaysian Prime Minister Mahathir visited China in August 1999, he said to Chinese leaders that he hoped China would support the establishment of an Asian Monetary Fund. Mahathir said that this would be helpful for regional financial security, and for an increased voice of Asia at global financial institutions. ${ }^{78}$ On 18 October 1999, Mahathir proposed an "East Asian Monetary Fund" at the East Asia Economic Summit, organized by the Geneva-based World Economic Forum, 'to empower the region to deal with economic and financial problems without outsiders' interference'. It was proposed to be 'deeply and constantly engaged in East Asian monetary cooperation and problems on a daily basis as opposed to a once-a-decade-when-crisis-strikes basis." 79 In November 1999, when Zhu Rongji visited Malaysia, he voiced his support for Mahathir's proposal of East Asian Monetary Fund and for the latter's call to reform the global financial system. ${ }^{80}$ This was followed by Chinese

\footnotetext{
76 "Joint Statement on East Asia Cooperation," ASEAN+3 Summit, Manila, the Philippines, 28 November 1999.

${ }^{77}$ Amyx, "Moving Beyond Bilateralism? Japan and the Asian Monetary Fund." Henning, East Asian Financial Cooperation.

${ }^{78}$ Wang, "Euro and East Asian Financial Cooperation."

79"Mahathir Proposes Creation of E. Asian Monetary Fund," Asian Economic News, 25 Oct. 1999.

80 “Zhu Rongji Gives Malaysia’s PM Support," VOA Report, 24 Nov. 1999. "China Supports Mahathir's Call to Reform Financial System," Bernama Daily Malaysian News, 24 Nov. 1999, Reuters China News, 24 Nov. 1999. Fan, "Lessons and Policy Implications."
} 
Foreign Ministry Spokesman Sun Yuxi's statement that China was willing to consider the proposal to establish an East Asia Monetary Fund. ${ }^{81}$

It can be said that the increased momentum to strengthen cooperation in East Asia added pressure on China to play a more supportive and active role. In the words of a Chinese member of PECC, "The impetus for regional economic cooperation was so strong that it became an inevitable trend for some mechanism to be established, even possibly without the participation of China; it became clear to Chinese policymakers that China must participate in the rules making of international institutions. ${ }^{, 82}$

\subsection{Financial security}

Apart from strategic calculations and the pressure from the regional discursive environment, was the idea of regional financial cooperation 'internalized' in China? As discussed previously, the Asian financial crisis heightened the Chinese government's awareness of national financial security and of the importance of regional cooperation for that purpose. There are two questions here. First, why did China become more active in regional financial cooperation only two years subsequent to the crisis? Second, did China think regional cooperation was helpful to its national financial security, in particular as it had accumulated a huge foreign reserve during the two years?

According to some Chinese scholars, the reasons why the Chinese government took two years to decide to take an active role in regional financial cooperation were the fragmented structure of China's policymaking system and the lack of transparency in the Chinese bureaucracy. On the one hand, the horizontal communication between state central agenciesthe central bank, the Ministry of Finance on international cooperation is not close or frequent because they are preoccupied by domestic issues. On the other hand, vertical communication is not smooth between junior and senior officials, and between researchers and policymakers. Wei Jianing from the Development Studies Centre of the State Council started advocating crisis

\footnotetext{
81 “'China 'Willing' to Consider East Asia Monetary Fund," Xinhua News Agency 25 Nov. 1999.

${ }^{82}$ Interview with a Chinese member of PECC, Beijing, April 2007.
} 
prevention since 1991 and thought that research on this issue had obtained attention from the leadership but the bureaucracy almost ignored his voice. ${ }^{83}$

As to the second question, as noted earlier, many Chinese scholars and policymakers think that China is unlikely to be hit by the kind of financial crisis that happened to East Asia in 1997. The Chinese government has gained confidence in its ability to avoid such a crisis because of its huge foreign reserves, increased drastically after the crisis, and the momentum of economic growth based mainly on exports and foreign direct investment instead of short-term capital. Neither do they expect bilateral swap arrangements like the CMI to be of particular use if China did have a crisis. Their reasons are, first, the amount of regional funding available for bailout is too little compared with the size of the Chinese economy - the rescue would be like a drop in a bucket, or in Chinese words 'a cup of water for a cart of wood on fire'. Second, as one of the leading economies in East Asia, if China fell into crisis, it would affect other regional economies as well, and therefore China would more likely be a donor rather than a recipient of financial aid in a regional financial crisis.

However, in their view, a swap arrangement is better than nothing for the region. As mentioned before, the Chinese economy would be affected if other countries in the region were hit by crisis because East Asia is an important destination of Chinese exports and source of investments into China. Moreover, the weakening of the regional economy as a whole is not conducive to China's global status because Beijing needs the region to raise its voice in the world.

Many Chinese scholars still argued for the necessity of strengthening financial cooperation because, first, domestic industrial and financial reforms in Asia, including in China, were still at an incipient stage, and the momentum for reform may be gradually lost when their economies recovered, although many factors that could lead to crises still existed. Chinese policymakers had realized the necessity of financial liberalization because the current financial system was hindering the development of China's financial market in particular and economic development in general. They were worried about the potential risks down the track of liberalization and hoped that regional financial cooperation would prevent crises through better

${ }^{83}$ Wang, "Views from China and the US." 
surveillance mechanisms. Second, there was increasing risk in the international financial market in the age of electronification and globalization, but a new international monetary system could not be established in the foreseeable future. China had learned, particularly from the WTO accession, that it needed to actively participate in international institution-building processes, in order to protect its national interests both at the regional level and the global level. ${ }^{84}$

In a word, China internalized the idea of regional financial cooperation, although through a long process, and such internalization still remained at a 'shallow' level because of its bureaucratic structure and the limitations with the domestic financial system.

\subsection{Symbolism \& Flexibility}

When the Chinese foreign policy apparatus granted political approval, the greatest constraint on China's depth of participation in regional financial cooperation was the level of China's financial development, in particular the level of development of the domestic financial institutions. Because of lack of confidence in the strength of domestic financial institutions, Chinese finance policymakers, in particular the central bank, were very cautious about any schemes of liberalization and avoided regional commitments that would compromise national financial sovereignty. Importantly, China supported the CMI because the bilateral swap arrangements were rather flexible and symbolic. As a form of financial cooperation, the CMI had a low starting point and a loose structure. The swap arrangements were to be negotiated bilaterally between regional governments; there was no plan of setting up a central decision mechanism or compulsory information sharing; countries had the choice to opt out of the arrangement when a crisis happened. Only 10 percent of the available drawing was not attached to IMF conditionalities (it increased to 20 percent after the Istanbul meeting in 2005); so whether to lend money to a country largely depends on whether that country was receiving IMF loans and the money at stake was not a big sum. For China in the early 2000s, maintaining sovereignty over economic matters enjoyed higher priority than international cooperation. This policy preference still remains a dominant principle in many aspects of Chinese foreign economic policy today, although China has become increasingly comfortable and confident to sign on to binding international commitments.

${ }^{84}$ Wang, "Euro and East Asian Financial Cooperation." 
In summary, guided by a more proactive diplomatic strategy and encouraged by a more congenial global environment for regional cooperation, Chinese policymakers modified the original CMI proposal to make it more useful for increasing China's political influence.

Regional dialogues among both government officials and scholars created an important external discursive environment that pressured China to seize the momentum of regional financial cooperation. The timing of the CMI proposal also came after China's two-year long process to internalize in domestic finance regulating institutions - the MOF and the central bank - the idea that regional financial cooperation was needed for national economic security. However, because the level of domestic financial development continues to constrain China's participation in regional financial cooperation, as Chinese finance policymakers are well aware, China could give full support for the launch of the CMI but it is a question of how much it can remain committed to deeper financial cooperation. As will be discussed in the next section, the flexible and symbolic nature of the $\mathrm{CMI}$ has been increasingly criticized by proponents of deep regional financial cooperation, and to what extent countries can accept programs of upgrading the CMI has become a test ground of their commitment to regional cooperation. The national performance in this test depends not only on the political views of the foreign policymakers, but increasingly on whether the economic policymakers think the domestic system is ready.

\section{$5 \quad$ Upgrade the CMI?}

After the initial welcome given to the CMI, observers of East Asian financial cooperation have frequently pointed out that the CMI was largely symbolic and that it would have very limited use in preventing or managing crises. One year after the launch of the CMI, at the 2001 ASEAN+3 Finance Ministers Meeting, East Asian countries decided to "review the current main principles of the bilateral swap agreement under the CMI in three years, taking into account of the actual operation of the BSA and other relevant factors". Between 2001 and 2004, although a number of bilateral swap arrangements were signed and the amount of funding was expanded under the CMI, it seemed that fundamental measures that could enhance the utility of the CMI were still underdeveloped, and that the CMI would die down if it was not pushed forward. 
East Asian governments and scholars conducted discussions and studies on the limitations of the current CMI and suggested several ways to upgrade it. In particular, the joint studies endorsed by regional summits promoted consensus among scholars from different countries, on matters such as the necessity of strengthening surveillance mechanisms and setting up regional resources for future crisis rescue. The 2003 ASEAN+3 Finance Ministers Meeting welcomed their Deputies' initiative in setting up a voluntary research group to explore ways to further strengthen financial cooperation and promote financial stability in the region, and Japan offered to make a significant financial contribution to this research. In 2004 the Japanese Institute of International Monetary Affairs came up with several suggestions on strengthening the ASEAN +3 mechanisms and upgrading the CMI, with multilateralization and institutionalization as the long-term objectives. ${ }^{85}$

As will be discussed in more detail below, China's responses to such proposals have been formed in a small policy circle - mostly among the MOF, the central bank and a few scholars that the two government agencies invited, as well as the MFA, whose political view determines the overall tone of China's degree of commitment. The limited number of participants is because policymaking on regional financial cooperation requires a high level of economic expertise and confidential information regarding the domestic economy, apart from politicostrategic considerations. Overall, China has actively participated in regional discussions on financial cooperation but has in general held a conservative attitude towards those suggestions, like some other East Asian countries. That is because upgrading the CMI essentially requires countries to surrender part of their economic sovereignty, which is considered risky by domestic financial regulators if domestic financial institutions are not developed to a certain level.

Therefore regional cooperation is unlikely if there is not enough political trust between regional members. However, China has started to be more proactive and supportive. On the one hand, Beijing has more financial resources to provide for international financial cooperation as China's economic power grows. On the other hand, the momentum towards upgrading the CMI 
at regional first- and second-track forums pushed the Chinese government to take a more cooperative stance.

\subsection{Multilateralization \& Independence}

One criticism of the bilateral swap arrangements under the CMI is that they had to be initiated one by one depending on the agreement of each donor country when a crisis happens, which would not rescue crisis-hit countries in a timely manner. Another is that the amount of funding immediately available was very limited - only 10 percent of the total swaps initially could be withdrawn without the IMF's agreement, which was increased to 20 percent in 2005 . By 2008, the bilateral swap arrangement network had been increased to USD 80 billion consisting of 16 BSAs among 8 countries (the proportion of the amount of contribution between the ASEAN and the Plus Three countries being 20:80), up from USD 17 billion of six BSAs among six countries in 2002. By the end of 2007, China has signed BSAs with Thailand (USD 2 billion), Malaysia ( $\$ 1.5$ bil), the Philippines ( $\$ 2$ bil in local currencies), Indonesia ( $\$ 4$ bil), Korea ( $\$ 8$ bil, two-way in local currencies) and Japan ( $\$ 6$ bil, two-way in local currencies). As China's economic power grows, it has more financial resources to spend to achieve its diplomatic objectives. By 2003, it had accumulated a foreign reserve of USD 403 billion, and 610 billion by 2004 . However, the premium sum of China's BSAs are said to be relatively high, and China preferred rigorous activation process - 100 percent linkage of the CMI funds to IMF conditionality. ${ }^{86}$ That reflects China's cautious attitude towards international financial commitments.

In order to increase the liquidity of and facilitate multilateralization of the CMI, the Japanese IIMA proposed to set up an 'earmarking arrangement' as a mid-term support mechanism for East Asian financial cooperation - short-term being the bilateral swap arrangements, and long-term being a single currency area. ${ }^{87}$ Under this arrangement, member countries must make a specific commitment that when a crisis happens, they provide a certain amount of liquidity out of their foreign reserves outside the existing CMI bilateral swap

\footnotetext{
${ }^{86}$ Jennifer Amyx, "Regional Financial Cooperation in East Asia since the Asian Financial Crisis," in Crisis as Catalyst: Asia's Dynamic Political Economy, ed. Andrew Macintyre, T.J. Pempel, and John Ravenhill (Ithaca: Cornell University Press, 2008).

${ }^{87}$ IIMA, "Report Summary of Studies on Toward a Regional Financial Architecture for East Asia", ASEAN $+3 \quad$ Finance $\quad$ Ministers Meeting, 29 March 2004, http://www.mof.go.jp/jouhou/kokkin/ASEAN+3research-1-1.pdf.
} 
arrangements. The Chinese CASS, on the other hand, suggested that such a mechanism for preventing and recovering from liquidity crises could not constitute a platform for high-level policy dialogue or further monetary cooperation. CASS put more emphasis on the institutionalization of the information exchange and policy dialogue, as well as the establishment of a coordination mechanism for efficient decision and supervision of loans. ${ }^{88}$

A remarkable development in the multilateralization of the CMI is that a reserve pooling ${ }^{89}$ has been set up from the swap arrangements, an achievement that Chinese policymakers take pride in. At the 2006 ASEAN+3 Finance Minister's Meeting in May 2006, the 13 countries adopted collective decision-making procedure for the swap activation, and in 2007, following the recommendation of the New Task Force for CMI Multilateralisation set up by the Deputies in the region at the 2006 ASEAN+3 Finance Ministers Meeting, they unanimously agreed in principle that a self-managed reserve pooling arrangement governed by a single contractual agreement is an appropriate form of multilateralization. ${ }^{90}$ It is the result of efforts of the "second phase' of the CMI review since the Istanbul meeting in 2005, and a further step towards the CMI multilateralization or Post-CMI. When strengthening the regional liquidity support network was initiated at the Jeju ASEAN+3 Finance Ministers' Meeting 2004, China applied to carry out the study on reserve pooling, which shows that China had learned that such studies would have a significant impact on regional collective policymaking. As a result, China and Thailand, as the chairmen of the 2007 ASEAN+3 Finance Ministers' Meeting, conducted the joint study of the reserve pooling proposal. In China, the MOF and the central bank carried out the study together, and invited scholars from CASS to participate. The result of the joint study supported the proposal of reserve pooling and became a foundation for the endorsement of such a policy by governments in the region.

Since reserve pooling is an important step towards realizing multilateral financial cooperation in a form that is very similar to the AMF proposal in 1997 (if its surveillance system and conditionality independent of the IMF are also established), China's support

\footnotetext{
${ }^{88}$ Ibid. Gao, "From CMI to ABF."

${ }^{89}$ Reserve pooling is a kind of international financial arrangement in which each member country put a certain amount of foreign reserve into a collective pool for future usage by members in crisis.

90 "The Joint Ministerial Statement of the $9^{\text {th }}$ ASEAN+3 Finance Minister's Meeting" and "The Joint Ministerial Statement of the $10^{\text {th }}$ ASEAN+3 Finance Minister's Meeting," available at http://www.aseansec.org/18390.htm and www.aseansec.org/18352.htm.
} 
signified a shift in this policy area. As mentioned before, although China did not support the AMF proposal because of political reasons and fear of being infected by the crisis, the Chinese government realized later that China could not improve regional relations or build the image of a responsible great power without actively supporting regional financial cooperation.

Importantly, Beijing wanted to play a key role in the policymaking on big regional decisions.

The Ministry of Finance, the leading government agency for China's regional financial cooperation, started to seriously consider deeper participation in regional financial cooperation in 2003 because the CMI was going to be reviewed in 2004 and might be abandoned if found not meaningful. In 2003 the MOF, the central bank and a few scholars carried out a domestic assessment on the consistency of regional financial cooperation with China's aims in domestic reforms. The report of the study is not published but according to one participating scholar, the conclusion was positive. Since then, China has taken a much more supportive and active role in regional financial cooperation. China is now only careful to avoid the title 'Asian Monetary Fund' being granted to regional financial cooperation because the term was proposed by Japan in $1997 .^{91}$

As to the high dependence on the IMF conditionality, as a result of the 2004 review, the Istanbul ASEAN+3 Finance Ministers Meeting 2005 decided to increase the size of the swaps that could be withdrawn without IMF-supported program from 10 percent to 20 percent 'in order to better cope with sudden market irregularities'. Chinese researchers at CASS think that the CMI should continue to gradually disconnect with the IMF conditionality if it is to be really useful. They argue that swap arrangements are a financial instrument chosen by lender countries with the awareness of taking certain credit risks, and therefore the lenders should have the right to negotiate for the conditionality. Contrary to the IMF's argument that a regional fund may cause moral hazard problems, CASS argues that disconnecting with the IMF conditionality helps avoid moral hazard because regional members, particularly lenders, take ownership of the programs. Moreover, the Chinese government is less concerned about US objections like that on the AMF proposal in 1997 because it thinks that the US understands that China would not give up its global role for its regional role, and Sino-American relationship is a major part of China's

${ }^{91}$ Interview with Gao Haihong, CASS, May 2007. 
global relations. However, because of the region's reliance on the IMF and World Bank for loans and aid, and its lesson from the failure of the AMF proposal, ASEAN+3 countries continue to express their determination that the CMI is intended to 'supplement' the existing international financial institutions, and that "the current framework to complement the international arrangements and other disciplined conditions would be firmly maintained." ${ }^{, 92}$ In 2008, the Finance Ministers reiterated that while keeping to timely disbursement, the CMI multilateralization would be underpinned by 'rigorous principles' to govern its key aspects. ${ }^{93}$

\subsection{Institutionalization}

There is a consensus among experts in the region that for the CMI to become a truly useful mechanism for dealing with short-term liquidity difficulties in the regional countries, and to develop into a regional financial institution in the long term, it needs to have independent surveillance and assessment mechanisms, as well as a central decision-making body, or a regional equivalent of the IMF which was envisaged for the AMF in 1997. There is a question, however, of how much of the experts' view is shared by the Chinese government.

\section{Surveillance}

The major surveillance mechanism under the CMI is the Economic Review and Policy Dialogue (ERPD) introduced in May 2000. Its focus is on monitoring regional capital flows and strengthening banking and financial mechanisms. It also supports reforms aimed at enhancing self-help and support mechanisms in East Asia and reforms related to the international financial architecture. The form of the EPRD is that each national committee presents a national report at ASEAN+3 Finance Ministers' Meetings, followed by questions and answers. There is no clear guideline for the internal surveillance in East Asia like that at the IMF, and the policy coverage is not clearly defined either. Countries are not required to immediately respond to all the questions posed by other members. This kind of mechanism cannot really put pressure on governments to introduce domestic reforms. Although the international image arguably affects states' behaviours, the non-interventionist Asian culture has remained an obstacle to the

92 "The Joint Ministerial Statement of the $8^{\text {th }}$ ASEAN+3 Finance Ministers' Meeting", Istanbul, Turkey 4 May 2005, available at http://www.aseansec.org/17448.htm.

93 "The Joint Ministerial Statement of the $11^{\text {th }}$ ASEAN+3 Finance Ministers' Meeting", 4 May 2008, available at http://www.aseansec.org/21502.htm. 
effectiveness of such forums. Besides, the current objective of ASEAN +3 surveillance is crisis prevention, which may be achieved through an informal process like the current EPRD, but it is far from being a proper surveillance mechanism in an institutionalized financial cooperation that East Asian countries allegedly aim to achieve. ${ }^{94}$

A report by the Japanese Daiwa Institute in July 2006 pointed out that mechanisms for assessing regional financial vulnerabilities were not yet as effective because (apart from the $\mathrm{ADB}$ provision of data on member countries) there has yet to be an independent, professional organization that prepares comprehensive analytical assessment papers to review and support the surveillance process. Following the suggestions by the Daiwa Institute, at the Hyderabad ASEAN +3 Finance Ministers' Meeting in 2006, the 13 countries decided to launch the Group of Experts (GOE) as an independent economic assessment vehicle, and the Technical Working Group on Economic and Financial Monitoring (ETWG) to develop the early warning system.

However, in 2007, East Asian finance ministers reaffirmed the central role of the ERPD as the key mechanism for ASEAN +3 surveillance, while allowing the possibility of incorporating the outcomes of the GOE and the ETWG. ${ }^{95}$ According to Chinese scholars, the Chinese government, represented by the MOF and the central bank, is still not comfortable with releasing detailed information of its domestic financial system unless being forced to. Political trust is certainly crucial in a country's willingness to give information important to national economic security to other countries to ensure that such information would not be exploited, and it is questionable whether such trust exists among key East Asian members. Besides, the Ministry of Finance and the central bank need to prepare data for submission to international financial institutions, from which China receives loans and aid, and Chinese officials think regional review would be an extra burden on their bureaucratic capacity. The resources allocated to studies on regional financial cooperation have been very limited compared with

\footnotetext{
${ }^{94}$ Yunjong Wang and Deok Ruong Yoon, Mechanisms of Regional Surveillance in East Asia and Its Prospects (2004 [cited 13 Nov 2007); available from http://www.mof.go.jp/jouhou/kokkin/tyousa/tyou04le.pdf.

95 “The Report of ASEAN+3 Finance Ministers' Meeting," Kyoto, Japan, 5 May 2007.
} 
those on global financial issues, not to mention the low status of the International Department within the Ministry of Finance because of the Ministry's preoccupation with domestic issues. ${ }^{96}$

Even at the IMF, the transparency of China has been in question. Some IMF personnel commented that China attempted to keep some information to itself. ${ }^{97}$ At the 1999 Annual meetings of the World Bank and IMF, Xiang Huaicheng insisted that "increasing transparency of all market participants will help efficiency and prevent crisis. But lack of transparency is not the main cause of the financial crisis. We are not in favor of mandatory enforcement in any form. ${ }^{" 98}$ China's sensitivity over the issue of information transparency is related to its level of economic development. Because the Chinese economy is in transition, many aspects of the domestic financial system cannot satisfy international standards. The government would like to keep control of the domestic financial system and of the pace of reform so as to maximise financial stability and security. Because financial cooperation involves much more commitment and is more intrusive than trade agreements, the Chinese government is afraid of losing control of the Chinese economy by releasing domestic financial information.

\section{Supranational body}

The issue of setting up an over-arching central decision body is even more sensitive to East Asian countries, including China. Many observers on East Asian financial cooperation have identified the lack of willingness of East Asian countries to give up sovereignty as the main obstacle to deepening cooperation. As some Chinese scholars believe, judging from East Asia's economic power and the recognition of the international society towards the AMF-type arrangement, substantial obstacles have been removed to developing the limited bilateral swap arrangements into a reliable regional fund; however, the willingness and sincerity of national governments to participate in deep East Asian financial cooperation needs testing. The scholars are worried that with the growth of Asian economies, the momentum for deepening regional financial cooperation might be lost. ${ }^{99}$ Many blame the problem on Asian culture, which

\footnotetext{
${ }^{96}$ Interview with an MOF official, Beijing, March 2006.

${ }^{97}$ Ann Kent, Beyond Compliance, p. 132.

98 "Statement by the Hon. Xiang Huaicheng, Governor of the Fund for the People's Republic of China at the Joint Annual Discussion," 28 September 1999, available on the IMF's website at http://www.imf.org/external/am/1999/speeches/pr15cne.pdf.

${ }^{99}$ Xuan Lv and Wei En, "Yazhou Huobi Jijin: Huigun he Zhanwang [Asian Monetary Fund: Retrospect and Prospect]," Zhongguo Waihui Guanli [China Foreign Exchange Management], no. 10 (2003). Fan He,
} 
emphasizes non-interference, non-contractual consensus building, which is largely true. Others think one factor was the lack of supra-national political institutions like the European Commission in East Asia. ${ }^{100}$ They have also pointed out a central problem - the lack of trust between key members, namely China and Japan.

Although Japan has been the most enthusiastic proponent of deepening financial cooperation in East Asia, for China, the time is still too early to realize such programs. One reason is the lack of confidence in the domestic financial system to handle the risks from surrendering national policy control to the region. Another reason is that because China's financial power is still not as strong as Japan's, Beijing thinks that any regional financial institution established now would institutionalize this power imbalance. That is not acceptable to Chinese foreign policymakers, nor do Chinese economic policymakers think that it would reflect the future power distribution between China and Japan. As a result, the voting power of China at a prospective central decision body for the CMI has been a contentious issue under negotiation. China prefers it to reflect the possible future distribution of financial power among regional members, while Japan prefers it to simply reflect the current distribution. ${ }^{101}$

\section{Exchange Rate Coordination}

While multilateralization and institutionalization of the CMI into a regional fund is viewed by scholars in the region as the mid-term objective of East Asian financial cooperation, exchange rate coordination, or monetary cooperation, is envisaged as the long-term objective. When East Asian countries were discussing regional financial cooperation, they witnessed the launch of the Euro by the European Union, and noticed that some American countries, such as Argentina, Salvatore and Mexico had been stimulated by Europe and advocated the dollarization - the replacement by the US dollar - of its own currency. Chinese scholars cautioned that the world might become two currency blocs dominated by the Euro and the US dollar respectively, and

Bin Zhang, and Ming Zhang, "After the CMI: The Future of Asian Monetary Cooperation and China's Role", China Academy of Social Sciences, 2005,

${ }^{100} \mathrm{He}$, "Asian Monetary Cooperation after Crisis."

${ }^{101}$ Interview with a scholar, CASS, May 2007. 
that Asia could either become subservient to them, or establish its own currency area. ${ }^{102}$ When the Asian financial crisis led to a collapse of the then prevailing de facto US dollar-pegged exchange rate regimes in East Asian economies, exchange rate coordination became a heatedlydebated topic in East Asia. Some argue that without exchange rate coordination, East Asia will be perennially vulnerable to crisis contagion because of the correlated nature of capital flows and structural shocks. Some East Asian countries moved to more flexible exchange rate regimes and started to consider coordinating their exchange rates in order to stabilize their currencies. For instance, ASEAN set up a Task Force on Currency and Exchange Rate Mechanism in March 2001 to examine the desirability and feasibility of regional exchange rate coordination, which conducted a study on forms of regional cooperation to promote currency stability but does not seem to have had much impact on policies so far. However, as will be discussed below, huge differences in economic development levels and remaining historical issues create various obstacles for reaching a broad consensus on cooperation in East Asia. ${ }^{103}$ As Gabriel Singson, Chairman of the JG Summit Capital Markets Corp of the Philippines, commented on the progress of East Asian monetary cooperation: "The best that can be achieved for the present is to ensure the consistency of macroeconomic fundamentals and sustain structural reforms. Dialogue, on the choice of exchange rate regimes and exchange rate policies, will help authorities understand better the exchange rate policy of each country in the region." 104

\subsection{An Optimum Currency Area?}

A heatedly-debated topic on East Asian monetary cooperation is whether East Asia satisfies the conditions of an 'optimum currency area' (OCA), a theory proposed by Robert Mundell in 1961 and refined by other economists. According to Mundell, the criteria for an OCA are the region's internal factor mobility and external factor immobility as well as the willingness of national governments to give up part of sovereignty to the region. ${ }^{105}$

\footnotetext{
102 Wang, "Euro and East Asian Financial Cooperation."

${ }^{103}$ Bin Zhang and Fan He, "Is Asian Currency Unit Attractive to East Asian Economies?," China and World Economy 15, no. 1 (Jan-Feb 2006).

104. Marie-Aimée Tourres, "Monetary and Financial Cooperation: Specific Proposals for East Asia," Report of the Second East Asia Congress held by the Malaysian Institute for Strategic and International Studies in May 2004, online at http://www.isis.org.my/files/eaec/3MonetaryFinancialCooperation.pdf. ${ }^{105}$ Robert Mundell, 'A Theory of Optimum Currency Areas', The American Economic Review, 51 (1961): 657-65,
} 
Applying it to Asia in 2003, Mundell commented that Asia could not have a single Asian currency in the near future because it would involve more political integration than was now possible between China and Japan. He noted that the institutional, economic and political groundwork had already been laid in Europe before it launched the Euro, while very little existed in Asia. ${ }^{106}$ Many studies have used this theory to assess the possibility of establishing a monetary union in East Asia, taking into consideration factors including: the degree of trade integration, labour and capital mobility, capital account liberalization, similarity in macroeconomic policy, diversification of economic structure and symmetry to external shocks. The results are mixed. ${ }^{107}$

Mundell's OCA theory has widely influenced Chinese scholars. Some famous scholars at CASS highlighted Mundell's prediction in 2000 that there would be three currency areas in the world in the next ten years - the Euro area, the US dollar area and the Asian currency area. ${ }^{108}$ Many studies in China have adopted the OCA theory to assess the possibility of adopting a common currency in East Asia and have reached mixed conclusions. Some believe that intraregional trade has developed substantially and the sub-regional free trade agreements in East Asia may gain momentum to provide a foundation for a common currency area, although domestic regulatory mechanisms are not developed enough to avoid financial risks without capital controls. ${ }^{109}$ Others think that intra-regional trade is still not developed enough to form a foundation for financial cooperation, and that currently East Asian trade still relies heavily on third-country markets. ${ }^{110}$ Some, including an official at MOFTEC, proposed to establish

\footnotetext{
${ }^{106}$ Robert Mundell, "Prospects for an Asian Currency Area," Journal of Asian Economies 14, no. 1 (February 2003), Mundell, "A Theory of Optimum Currency Areas."

${ }^{107}$ See for example, Mundell, "Prospects for an Asian Currency Area." Eichengreen, "International Monetary Arrangements: Is There a Monetary Union in Asia's Future?", Eichengreen, "Real and Pseudo Preconditions for an Asian Monetary Union". Sung Yeung Kwak, "An Optimum Currency Area in East Asia: Feasibility, Coordination, and Leadership Role " Journal of Asian Economics 15, no. 1 (February 2004). Dieter and Higgot, "Exploring Alternative Theories of Economic Regionalism: From Trade to Finance in Asian Co-operation?."

${ }^{108} \mathrm{Yu}, \mathrm{He}$, and Li, "Yazhou Jinrong Hezuo: Beijing, Zuixin Jinzhan yu Fazhan Qianjing [Asian Financial Cooperation: Background, Progress and Prospects]." Robert Mundell, "Currency Areas, Exchange Rate Systems and International Monetary Reform," Journal of Applied Economics 3 (November 2000).

109 "ASEAN+3 Study Group Report on Trade, Investment and Financial Integration in East Asia 20042005", ASEAN+3 Study Group, 2005, http://www.aseansec.org/17880.htm. Haihong Gao, "Monetary Cooperation in East Asia: How Far Can East Asian Countries Go?" (paper presented at the East Asian Monetary Cooperation and China's Perspective Conference, Beijing, 24 August 2007). Ruiping Jiang, "Dangqian Dongya Jinrong Hezuo Xingshi Pinggu ji Jianyi [A Review of and Suggestions for Current East Asian Financial Cooperation]," Waijiao Pinglun [Review of Diplomacy], no. 3 (2007).

${ }^{110}$ Zhang and He, "Is Asian Currency Unit Attractive to East Asian Economies?." Min Zhu, "Quanqiu
} 
Northeast Asian financial cooperation as the first step and then invite ASEAN countries to join, but realized that the problem with this plan was that South Korea and Japan could not liberalize trade between each other. ${ }^{111}$ Using the generalized purchasing power parity model, CASS finds that as far as the US is concerned, ASEAN +3 countries meet preconditions of a potential OCA because they have close links with the US in terms of trade and investment. If Japan is used as the base country, there also appears to be enough economic linkage among ASEAN+3 countries to establish a high-level monetary arrangement, which indicates that existing regional monetary arrangements lag far behind real economic linkage. ${ }^{112}$ The lack of institutional development, again, is not only caused by the different levels of economic development among East Asia countries, but also by lack of political trust between key members like China and Japan, as well as by the lack of confidence in domestic economic management if sovereignty is partially surrendered to a regional body.

\subsection{Japanese proposals}

Japan has been the most active proponent of East Asian monetary cooperation and has come up with several plans for exchange rate coordination. The IIMA of Japan proposed the Group-3 Basket in 1998, under which East Asian countries peg their currencies to a basket of the US dollar, the Euro and the Japanese yen. ${ }^{113}$ Chinese policymakers and scholars alike have criticized this plan heavily on the basis that it would not serve the original purpose of East Asian financial cooperation - to build an East Asian monetary regime that is independent of the US dollar - and that it would only help strengthen the role of the yen in the region and cater to Japanese national interests. A more radical suggestion from Japan is to use the Japanese yen as the single currency in East Asia, which undoubtedly received obstinate opposition from China. Although many of them are economists who hope for progress in regional financial cooperation, Chinese scholars hold that the ultimate motivation behind Japan's various proposals for regional monetary cooperation was to promote the internationalization of the yen in order to enjoy

Liudong Guosheng Beijing xia de Dongya Jinrong Hezuo [East Asian Financial Cooperation in Excess Global Liquidity]," Waijiao Pinglun [Review of Diplomacy], no. 3 (2007).

${ }^{111}$ Wang, "Euro and East Asian Financial Cooperation."

${ }^{112}$ Gao, "How Far Can East Asian Countries Go?"

113 Takatoshi Ito, Eiji Ogawa and Yuri Sasaki, "Establishment of the East Asian Fund," in Stabilisation of Currencies and Financial Systems in East Asia and International Financial Cooperation, edited by Institute for International Monetary Affairs (Tokyo: IIMA, 1999). 
several benefits as the seigniorage country — to hedge domestic traders and investors against exchange rate risk, to diversify portfolio risk and to enhance Japan's international political status. ${ }^{114}$ In their view, becoming the seigniorage country would help Japan to institutionalize its current financial predominance in the region even when its economy declines in the future. As a matter of fact, the Japanese government's enthusiasm for internationalization of the yen came only after the crisis when Japan's economic predominance in the region was waning.

The IIMA also proposed an Asian Monetary Unit (AMU), made up of all the 13 currencies in East Asia. Like the European Currency Unit under the European Monetary System from 1979 to 1998, the weight of each currency in the AMU would reflect the economic size and performance of each country, and the AMU would be used as a reference for East Asian countries to adjust their exchange rates based on how much the national exchange rate deviates from the average exchange rate of the region. The Asian Development Bank adopted the AMU plan and proposed the idea of an Asian Currency Unit (ACU) in 2005.

\subsection{The Asian Currency Unit}

According to the $\mathrm{ADB}$, the $\mathrm{ACU}$ may be used as an indicator to monitor how Asian currencies are moving collectively vis-à-vis key external currencies like the US dollar, the Euro and the British pound, and how each Asian currency is moving against such a regional benchmark in order to control excessive fluctuations. It is also proposed to be used as a denominator for bonds launched by the $\mathrm{ADB}$ or a currency unit at regional financial markets. Some Chinese scholars think that "the ACU is a constructive and flexible proposal": 115 If the ACU is well received by the relevant countries, it can play a great role in preventing competitive devaluation and regional exchange rate fluctuation; it will also contribute to facilitating regional exchange rate adjustment, reducing the dependency of East Asian economy on the US dollar, lessening the burden of maintaining large scale out-of-the-region foreign currency reserves, correcting the global imbalance and promoting the integration of East Asian economy.

114 Pascha, "Regional Financial Arrangements and Monetary Integration in East Asia and Europe."

${ }^{115}$ Zhang and He, "Is Asian Currency Unit Attractive to East Asian Economies?" 
However, exchange rate coordination as a form of deep financial cooperation requires countries to give up part of their economic sovereignty, for instance on exchange rates, and monetary and fiscal policies. For China, the ACU needed to be more attractive than the US dollar peg (and from 21 July 2005 the central bank incorporated a 'reference basket' of currencies of the "countries to which China has a prominent exposure in terms of foreign trade, external debt, and foreign direct investment' for its RMB target ${ }^{116}$ ) and strict capital controls. For East Asia, a region with diverse levels of economic development and financial systems, it is very difficult to achieve consensus on this proposal.

The launch of the ACU was delayed from March 2006 to June 2006 and then again because of different opinions among regional members. It is reported that one point of contention was the proposal to incorporate currencies of Taiwan, Hong Kong, Australia and New Zealand. ${ }^{117}$ It is likely that China would not like an inter-governmental regional cooperative arrangement to include Taiwan, but China has opposed the launch of the ACU as a formal currency for East Asia for other reasons as well.

One is that China's level of economic development poses a constraint to its participation in deep international financial or monetary cooperation. Regional financial integration involves allowing free flow of capital but China's capital account is not yet liberalized. Regional financial cooperation also requires the participation of banks but Chinese banks and the financial system in general are still very fragile. In particular, the Chinese financial system is in the process of implementing WTO commitments such as allowing foreign banks to set up branches in China and the impact is yet to be seen clearly. As argued by the ASEAN+3 Study Group in 2005, financial integration must be preceded by domestic financial sector reforms. A scholar at CASS points out that China's degree of capital liberalization is similar to that of developed countries in the late 1960s to 1970 s, but China is facing much higher risk in the international financial environment, and China does not have enough legal or technical means to

\footnotetext{
${ }^{116}$ People's Bank of China, "Public Announcement of the People's Bank of China on Reforming the RMB Exchange Rate Regime," 21 July 2005. People's Bank of China, "Speech of Governor Zhou Xiaochuan at the Inauguration Ceremony of the People's Bank of China Shanghai Head Office," 10 August 2005, http://www.pbc.gov.cn/english/detail.asp?col=6500\&id $=82$

${ }^{117}$ Victor Mallet, "Bickering Delays Asian Currency Launch," Financial Times, 26 March 2006.
} 
disperse risks. ${ }^{118}$ Therefore, capital controls are still necessary at the domestic level until domestic institutional reforms are in place. ${ }^{119}$

Importantly, Chinese scholars believe that for regional monetary cooperation to be realized, there has to be an anchoring economy like Germany for the Euro. It is too early for China with its immature financial system and not-fully convertible currency to accept the position as a lender of last resort. ${ }^{120}$ The yuan is pegged to a basket of currencies now, but is not yet convertible. The Chinese central bank, the People's Bank of China, announced that China would initiate exchange rate reform and would increase the flexibility of RMB/USD rate. At the same time, the Bank emphasized the significance of RMB/USD rate in the short term. Although the RMB has been increasingly used in regional businesses ${ }^{121}$ and the Chinese government has started studying the possibilities of internationalizing or regionalizing the RMB, as can be seen from the movement of the RMB exchange rate so far, the Chinese central bank is very prudential about floating the RMB. The Japanese yen is convertible and the yen has been the most widely-used regional currency in regional business transactions. If monetary cooperation is deepened, in the current circumstances Japan would most likely be the anchoring economy. That would not be seen as a good scenario for China.

A study by the CASS on the value of the ACU to China points out that the ACU cannot satisfy simultaneously three important objectives of China's current economic development: maintaining export competitiveness and stabilizing import cost, restoring external and internal balance, and reducing excessive exchange rate fluctuations. ${ }^{122}$ In particular, China can hardly formally accept a common basket peg scheme in the near future because it still seeks to keep a stable bilateral nominal exchange rate between the RMB and the US dollar, since most of China's foreign assets and trade are denominated by the US dollar and China's domestic financial market, especially the foreign exchange market, is too shallow to hedge exchange risks

\footnotetext{
${ }^{118}$ Hong Chen, "Peiyu Dongya Zhaiquan Shichang: Xianzhuang, Zhang'ai yu Qianjing [Developing East Asian Bond Market: Status, Obstacles and Prospects]," Shijie Jingii [World Economy], no. 2 (2007).

119 "ASEAN+3 Study Group Report",

${ }^{120}$ Institute of Finance and Banking, CASS, "Guoji Jinrong Shichang [The International Financial Market]", in Zhongguo Jinrong Fazhan Baogao [China's Financial Development Report], Blue Book of Finance Series (Beijing: Social Sciences Academic Press, 2005): 254.

${ }^{121}$ Mamoru Ishida, "Regional Role for China’s Yuan", The Japan Times, 11 April 2008.

122 Zhang and He, "Is Asian Currency Unit Attractive to East Asian Economies?."
} 
efficiently. ${ }^{123}$ Compared with pegging the RMB to another currency or a regional currency basket, the existing RMB exchange rate brings about fewer obligations and more room for China's monetary authority to manoeuvre, although it may delay China's fundamental financial reform.

Another important reason for China's opposition to the ACU was the weight of each national currency in the basket. China's weight was the biggest in the original ACU plan. However, in 2006, Masahiro Kawai, then Head of the Office of Regional Economic Integration and Advisor to the Governor of the ADB (Haruhiko Kuroda), led an ADB delegation to CASS. They proposed to change the original proposed weighting of each currency in the $\mathrm{ACU}$, in particular, by adding indexes of the openness of the financial market, the restrictions on foreign exchange and whether the capital account is liberalized. That would marginalise China and some other countries and China would score lower than several East Asian countries; therefore China disagreed with the plan, arguing that under this plan, the ACU would be difficult to quantify and not useful to stabilize exchange rates. It is said that South Korea and some ASEAN countries also disagreed with the plan for similar reasons. ${ }^{124}$

In view of the proposal by the $\mathrm{ADB}$ that the $\mathrm{ACU}$ might be used in regional financial markets, Chinese scholars contended that what needed to be done was to construct an Asian Bond Market (ABM) so as to promote the integration of Asian Financial market infrastructures and reduce the difficulty of countries participating in monetary cooperation, rather than the opposite - to establish the Asian Currency Unit so as to develop the ABM. ${ }^{125}$ China has given support to the development of the ABM, but because of the limited level of domestic financial market, China does not think that it has enough capacity yet to be deeply involved in the ABM. More specifically, China, like many other East Asian countries, restricts foreign investment in national bonds. In 2002 China launched the Qualified Foreign Institutional Investors (QFII) mechanism to allow foreign financial institutions to open special RMB accounts in China.

\footnotetext{
${ }^{123}$ He, Zhang, and Zhang, "After the CMI",

${ }^{124}$ Interview, CASS, May 2007. Also see "Toward Greater Regional Stability in the Asian Region: Exploring Steps to Create Regional Monetary Units (RMUs)", Institution for International Monetary Affairs, Japan, March 2007,

${ }^{125}$ Sun, "Japan's Role and Influence." The development of the ABM is beyond the scope of this thesis because it does not involve much policy coordination among national governments, which is the focus of this thesis.
} 
However, it is still difficult for them to use this mechanism to invest in bonds in China. Besides, China's export heavily relies on markets outside the region as the final destination, which limits the attractiveness of the regional bond market to Chinese investors.

The US and some other countries outside ASEAN+3 had reservations about the ACU proposal as well because they were being left out. ${ }^{126}$ For instance, Australia and New Zealand hoped to join but China wanted to limit substantial regional economic cooperation to ASEAN +3 , arguing that inviting those two countries would cause other countries like Russia and India to join as well, and thus make issues more complicated. ${ }^{127}$ Therefore, conditions were premature when in 2006 the ADB President Kuroda announced the introduction of the Asian Currency Unit. In what seems a face-saving move, the ASEAN+3 Finance Ministers' Meeting asked a Japanese research institute to explore steps to create regional monetary units further. ${ }^{128}$ No real progress has been made on creating an Asian Currency Unit since Kawai left the position at the ADB. It is said that even Japanese scholars are not anymore enthusiastic about radical procedures because they have realized the practical obstacles in the region. ${ }^{129}$ As a result of both internal and external differences, the proposed $\mathrm{ACU}$ was shelved, and now the ADB only talks about an 'Asian Currency Index'.

\section{Domestic Institutions and Centralized Policymaking}

In this section, I will focus on the institutional features of China's policymaking on financial cooperation in relation to the degree of insulation of central policymakers and the degree of fragmentation of the state power. I will also summarize the Chinese government's political and economic motivations for participating in regional economic cooperation, the important role of ideas in the policymaking process, and discuss the potential for policy change that exists in the potential for institutional change.

In comparison with trade policymaking as analyzed in previous chapters, China's policymaking on regional financial cooperation is highly centralized, including only a few

\footnotetext{
126 “Asian Currency Index Now," The Economic Times, 28 Nov. 2006, http://economictimes.indiatimes.com/articleshow/609950.cms.

${ }^{127}$ Interview with an MOF official, Beijing, April 2007.

${ }^{128}$ Pascha, "Regional Financial Arrangements and Monetary Integration in East Asia and Europe."

${ }^{129}$ Interview, CASS, May 2007.
} 
actors - the Ministry of Finance, the central bank, the Ministry of Foreign Affairs and a few invited scholars - and well-insulated from domestic interest groups. That may be true in other countries as well, because finance policymaking requires a high level of expertise as well as confidentiality as it is directly linked to national economic security, and therefore only a very limited number of actors can participate in policymaking. In other words, the power of financial policymaking in China is insulated from domestic opinions by limiting the distribution of information. The implications of financial cooperation on domestic sectors are far less obvious than free trade agreements. Although a scholar from CASS speculates that 'liberals', including export-oriented sectors, foreign companies and coastal areas, would be more supportive for Asian monetary cooperation than 'reformists', including import-competing sectors and inland areas would be, ${ }^{130}$ there is virtually no participation by industrial sectors or local governments in China's policymaking on regional financial cooperation. ${ }^{131}$ Therefore, there is no such question as which domestic interest group has more influence on central policymakers than others do because of their different degrees of collective action. The concentration of policymaking power means that there is far less political objection from domestic actors to state initiatives on financial cooperation than on trade cooperation, although it does not mean that there are no different opinions or nuanced attitudes within the policymaking circle.

In the case of China, the policymaking power on regional financial cooperation is shared between the Ministry of Finance and the central bank - the People's Bank of China. As the highest financial policy apparatus in China, they enjoy a lot of power and autonomy. Although financial regionalism and trade regionalism are closely related and possibly mutually enhancive, there seems to be little coordination between the two policymaking circles: China's major trade policymaker, the Ministry of Commerce, has little involvement in China's policymaking on regional financial cooperation, although some MOFCOM officials and researchers are proponents for regional financial cooperation. The fact that MOFCOM cannot push forward financial integration that facilitates trade but Chinese financial policymakers such as MOF, the central bank and the Banking Regulation Commission participate in the policymaking of free

\footnotetext{
${ }^{130} \mathrm{He}$, "Asian Monetary Cooperation after Crisis."

${ }^{131}$ Ibid.
} 
trade agreements may confirm the widely held view that MOFCOM does not have as much political power in the central government as many other ministries, in particular compared with the financial ministries. The MOF may be a little more enthusiastic about deepening regional financial cooperation than is the central bank because the former represents China at ASEAN +3 Finance Ministers Meetings, where most decisions on regional financial cooperation are made, while the central bank gives national financial security absolute priority and does not want MOF to intervene in exchange rate and foreign reserve policies. Overall, however, these two agencies have close communication over regional financial cooperation and the positions between them are basically the same. Amongst others, the responsibilities of MOF and the central bank are to ensure national financial security and to carry out financial reforms for China's economic development. Importantly, they both prioritise domestic economic stability over international cooperation, which is reflected in the limited resources and the low status of the international departments in both agencies. The MOF and the central bank are somewhat interested in regional financial cooperation because China's economic security during liberalization can be assisted by regional financial cooperation, for instance, by regional surveillance and early warning mechanisms, and access to regional funds.

Like regional trade cooperation, regional financial cooperation is part of China's economic diplomacy, and the foreign policy apparatus - the Ministry of Foreign Affairs - plays an important intervening role in both policy areas, namely, endorsing proposals of international cooperation with what it deems 'politically reliable' countries to be further explored by economic ministries and disapproving those with countries that MFA does not trust for political reasons. Because international financial cooperation is arguably more intrusive than trade to a country's sovereignty and more directly linked with national economic security, political will is particularly important if a country is to agree to give up partial sovereignty and participate in financial cooperation. On matters central to financial cooperation such as the membership and the distribution of voting power of cooperation, the political considerations represented by MFA largely decided China's positions. If the membership and voting power are agreed upon, economic ministries play a dominant role in policymaking, and their judgement on China's 
economic conditions is most important as to what extent China should surrender national sovereignty to regional cooperation.

In the political considerations of China's foreign policy makers, on the one hand, the objective is to enhance China's image in the region as a responsible great power. This can be seen from its not devaluing the RMB and providing financial aid to Southeast Asian countries during the Asian financial crisis, suggesting ASEAN+3 Finance and Central Bank Deputies Meetings, advocating the participation of ASEAN in the Chiang Mai Initiative, financing regional studies on financial cooperation, providing training to Southeast Asian financial personnel, and its supportive gestures in ASEAN+3 dialogues. China also became more active in regional financial cooperation when the momentum for financial cooperation in the region grew to the extent that it judged irretrievable, in particular when it received more pressure from ASEAN. On the other hand, because of deep political mistrust for Japan, China tries to hedge against Japanese influence in the region, and to prevent Japan from institutionalizing its greater financial power in the region. It did not extend support to Japan's proposal for the AMF, and vetoed Japan's later suggestions of exchange rate coordination and of independent surveillance mechanisms. Keeping Taiwan out of all the inter-governmental regional cooperation remains a non-negotiable condition of China. At the same time, China needs to balance its role in East Asia with its relationship with the US. An important reason it did not support the AMF proposal was objection to the proposal from the US and the IMF. With the US becoming more tolerant of East Asian cooperation, China has become more proactive in supporting cooperation under the ASEAN +3 framework. It has an increasing voice, together with other East Asian countries, in calling for an enhanced role of Asia at international financial institutions and for reforming the international economic order.

As for the economic considerations from China's foreign economic policy makers, China started to consider regional financial cooperation out of a heightened sense of crisis and realization of the contagious effects of regional financial crises, and some Chinese scholars thought that regional cooperation might help China if it got into crisis. However, as China's economic growth continued and foreign reserves increased, the Chinese monetary authorities felt less and less need to rely on regional mechanisms for China's financial security, especially 
now that China has obviously become a donor or lender in the region if crisis happens. At the same time, China's financial policymakers are aware that China's level of domestic financial development constrains its participation in deep regional financial and monetary cooperation that requires China to surrender part of national sovereignty. The need to control fluctuation of the RMB's exchange rate to the US dollar, the immature conditions for liberalizing the capital account and the unwillingness to release information on the problematic domestic financial system all prevent Chinese financial policymakers at the MOF and the central bank from committing to regional initiatives such as exchange rate coordination and compulsory surveillance. China has resisted any influence by the IMF on its own domestic reform process, and holds the view that the pace of economic liberalization should be consistent with the level of economic development; China also opposes including enforcing domestic reform into the function of regional financial cooperation. Besides, top officials of the MOF and the central bank are preoccupied with domestic problems and reforms. International departments in these agencies are only in a minor position and the resources for regional financial cooperation are quite limited. Often, international cooperation is too complex for higher officials to understand and reply in a short time. In the Chinese bureaucratic culture, when leaders do not know issues well, they tend to shelve the proposals, and do not make a decision until further incentive comes up. Moreover, as a potential lender, China has tried to minimise its risks in lending money, by requesting that a close linkage should be maintained between the regional swap arrangements and the IMF, and by negotiating high premiums in its bilateral swap arrangements.

Apart from state political and economic interests, ideas certainly played an important role in China's participation in regional financial cooperation. A good example is the increased caution by Chinese policymakers and scholars after the Asian financial crisis about liberal economic ideas, or the Washington Consensus advocated by the IMF, and the belief in capital control, stable exchange rates and a generally conservative approach to financial reform. Scholars also played an important role in instilling ideas of regional financial cooperation in policymakers at both domestic and regional levels. Thanks to Chinese economists, no other theory of financial integration is more widely used in China than Mundell's Optimum Currency Area. As a result some Chinese scholars try to propel East Asian financial cooperation forward, 
based on the high level of intra-regional economic interactions and call for reforms of financial institutions that have constrained the 'natural' process of regional financial integration.

Importantly, scholars at CASS were invited by the Chinese government to give policy advice on regional financial cooperation because of their expertise and to participate in secondtrack discussions. This advisory role has provided an important foundation for government decisions. Scholars from CASS carried out the evaluation of the CMI for the 2005 Istanbul ASEAN +3 Finance Ministers Meeting and are trying to make it more substantive and effective The conclusion of another study by them that regional reserve pooling was consistent with China's development level was crucial in the Chinese government's bold move to support multilateralization of the CMI in 2007. Overall, Chinese scholars support strengthening regional financial cooperation on the ground that financial cooperation is helpful to prevent crisis in the region and in China in an increasingly risky global economic environment. However, they hold different views as to the appropriate pace and depth of China's participation in regional financial cooperation because they cannot decide on how China's policies can strike a balance between domestic development and international liberalization. Like the MOF and the central bank, many scholars believe that the major problem for China lies in domestic development, such as unemployment, inequality and overheating.

At the regional level, second-track dialogues and studies have helped foster consensus among scholars and provided a major foundation of information for first-track policy dialogue. They also created a regional discursive environment in support of further regional financial cooperation, which added momentum to regional financial cooperation and pressure on national policymakers in the region to cooperate. ${ }^{132}$ CASS even called for the establishment of a regional investment bank, in parallel to the ADB (like IMF in parallel to the World Bank), to promote regional economic integration. However, the enthusiasm of scholars is not always shared by the Chinese government because of the above-mentioned political considerations of foreign policy makers and economic constraints perceived by financial policymakers. Rather, it seems that Chinese scholars have become more receptive to the government's concerns, as can be seen from their caution against Japan's initiatives and against radical economic proposals.

${ }^{132}$ He, Zhang, and Zhang, "After the CMI", 
The potential for change in China's position on regional financial cooperation not only lies in its growing GDP, but also in institutional change. With an expanding economy, huge foreign reserves and increasing intricacy between foreign economic relations and domestic economy, China has started to review its finance policymaking institutions. Some in China started to call for a more sophisticated foreign reserve and exchange rate decision making mechanism - not only by the central bank, but collectively with MOF and the State Council like other developed countries such as the US, Japan, Singapore, and Germany. Reflected in regional financial cooperation, the lack of authority of MOF on foreign reserve and exchange rate policy impedes its effective representation at regional dialogues on financial cooperation. In a word, the new policy challenges faced by China in international liberalization, including liberalization required by regional financial cooperation, have the potential to trigger institutional change, and the form of the new institutions may derive from institutions in other countries. As Steinfeld noted, new-generation Chinese reformist policymakers tend to borrow Western institutions directly into China. ${ }^{133}$ The resultant change of the composition of major agents in the policymaking institution, if they materialize, would have a significant impact on China's policies, possibly towards deeper participation in regional financial cooperation.

Finally, it is worth noting that China seems to be more comfortable with multilateral cooperation rather than merely relying on bilateral means as it has in the past. That can be attributed to the process of first- and second-track regional dialogues, the awareness of the importance of participating in international institution building, and a more proactive diplomatic style as China's power grows.

${ }^{133}$ Steinfeld, "Embrace of Capitalism". 


\section{in China's Policymaking on Regional Economic Cooperation}

This thesis has explored the question of what factors determine China's policies on regional economic cooperation; in particular, it has asked why some interests or ideas have prevailed in policymaking at the expense of others. In the three case studies, namely, the ChinaASEAN FTA (CAFTA), the Australia-China FTA (AUCFTA) and East Asian financial cooperation, the Chinese government has adopted varied stances towards similar issues. For example, the FTA agreements in goods and services with ASEAN have been reached quite smoothly, in which China has made a lot of concessions, while the one with Australia has been extremely difficult to achieve. In particular, China voluntarily reduced agricultural tariffs to ASEAN countries, but has been insistent on agricultural protection in the negotiations with Australia. Moreover, in both FTA negotiations with ASEAN and Australia, China has heeded the voice of major services sectors to resist liberalization beyond its WTO commitments, but has largely ignored the pressures from manufacturing sectors to open up the other party's market. At the same time, although China seems to have embraced legally-binding trade agreements, it is still uncomfortable with international financial arrangements that may compromise its financial sovereignty. China has also taken opposite positions towards proposals of financial cooperation such as the Asian Monetary Fund (AMF) and the Chiang Mai Initiative (CMI). By looking into China's domestic policymaking, this study provides some explanations for the various policies.

As is shown in the case studies, a wide range of interests and ideas have entered China's policymaking, all having the potential to be decisive on the policy outcome. However, as suggested in Chapter Two, which interests or ideas eventually prevail over others is determined by the policymaking institutions, because the latter channel the interactions among those policy preferences, and sometimes even help to shape policy preferences. As a conclusion to the thesis, this chapter will summarize the interests and ideas that have been important policy inputs to China's regional economic cooperation, and then highlight the role of institutions in structuring policymaking and producing policy outcomes. More specifically, it will integrate the analyses of 
individual case studies on how the various policy outcomes can be explained by the three features of institutions suggested in Chapter Two, namely, the degree of insulation of the central policymaker, the degree of collective action within each domestic interest group, and the degree of fragmentation of the central policymaking power. This will be followed by summarising the evidence of how institutions change, focusing on institutional learning, the emergence of a new policy area, and the change of the leading agency. Finally, the implications of the research findings for studies of China's political economy, regionalism and foreign economic policymaking will be briefly discussed.

\section{Interests}

There is a range of motivations for the Chinese state to embark on regional economic cooperation, including considerations of national political and economic interests. Political and strategic interests have featured prominently in the cases, sometimes overriding economic costs. At the same time, a strong state initiative does not guarantee achievement of international cooperation. On the one hand, domestic interests can pose a serious constraint on the autonomy of the state. Even though China is traditionally perceived as an authoritarian state, the cases have shown that domestic interests have been able to exert increasing pressure on the central policymakers, sometimes forcing Chinese officials or even the leadership to take a conservative position in international negotiations. On the other hand, as will be discussed later, national differences in culture, domestic economic and political systems, and some key perspectives can be significant obstacles to effective negotiation on international cooperation.

\subsection{National interests}

\section{Political interests}

Political and strategic considerations have been important motivations behind China's participation in regional economic cooperation. It is part of China's 'good neighbourly diplomacy', which aims to promote a safe strategic environment for China to concentrate on economic development. It is also part of China's 'economic diplomacy', which denotes foreign economic policies that serves diplomatic purposes. 
The proposal of an FTA to ASEAN in 1999 was mainly intended to allay the latter's worries about China becoming an economic and political threat to the region upon its accession to the WTO. The eagerness to gain ASEAN's trust can be seen from China's initiative of an Early Harvest Programme, under which China reduced agricultural tariffs of interest to ASEAN products. A similar Early Harvest Programme existed in China's FTA with Pakistan. The decision to accept Australia's proposal of an FTA was also based on the evaluation of the SinoAustralian political relationship - that no fundamental political differences existed but it needed to be strengthened. At the same stage, an important reason that Chinese trade negotiators have been less willing to make concessions to Australia than to ASEAN is that the level of political commitment by the Chinese leadership to the AUCFTA is not as strong as that to the CAFTA: ASEAN is at the core of China's good neighbourly foreign policy, while Australia is more at the periphery. In fact, a political evaluation precedes economic study of every FTA and financial cooperation proposal that China has received; a process which prioritises countries that the Chinese government has political trust in. China has also remained supportive and attentive to East Asian financial cooperation since 1999 for political and symbolic values, although most Chinese policymakers do not think it would have actual economic benefits. Even with political support from the foreign policymakers, as will be discussed later, China's domestic economic conditions have constrained how much compromise Chinese economic policymakers can make in regional economic cooperation. Political distrust, on the other hand, has caused China to dismiss every regional initiative of Japan's so far, including the AMF and an East Asian Free Trade Area, only to replace them with Chinese-led initiatives such as the ASEAN $+3 \mathrm{CMI}$ and a Northeast Asian FTA.

Although Chinese spokesmen deny China's ambition to be a regional hegemon, it is undoubtedly seeking regional leadership in East Asia, or in other words, to take 'the driver's seat'. This has been demonstrated, for example, by proposing an FTA to ASEAN ahead of others and seeking the highest voting power in regional financial cooperation. A key driving force in this pursuit is Beijing's realisation that playing an important role in regional and international institution building and collective policymaking is crucial to protecting China's national interests. Therefore, sometimes China can be seen to hedge against Japan or the US, 
such as the CAFTA and the AUCFTA, and other times China focuses on extending its "charm offensive ${ }^{11}$ to developing countries in Southeast Asia, Africa and Latin America with preferential trade and financial aid. China's behaviour in FTA negotiations contradicts a general pattern observed by Freund that large countries extract greater trade concessions from small countries in free trade agreements. ${ }^{2}$ One reason is China's 'great country mentality' of giving more and taking less, as will be discussed later, in order to win strategic and political allegiance from smaller countries. It is subject to interpretation as to whether that mentality is benevolent (willing to provide public goods) or malevolent (coaxing long-term benefits by making shortterm concessions); the two intentions may co-exist - reaping political benefits from the system by providing economic goods, or vice versa. It also remains to be seen whether China can keep giving more to and taking less from smaller countries after its ascendancy in the world economy. ${ }^{3}$ However, China's behaviour supports Pahre's argument that strategic competition has a positive impact on the tendency of hegemons to participate in international cooperation, and that hegemons may supply public goods only to (prospective) strategic allies, as the US did after World War II. ${ }^{4}$

Regional economic cooperation also helps China to speak as a representative for East Asia and for developing countries at global forums, where these groups call for a stronger voice and a new world political economic order. China appreciates ASEAN's support for its accession into the WTO, and since its accession it has called for developed countries to make more concessions at the WTO and to show more consideration for developing countries. At their annual finance ministers meetings, ASEAN +3 countries have repeatedly called for a quota

\footnotetext{
'Kurlantzick used the term 'charm offensive' to describe China's use of soft power. Joshua Kurlantzick, Charm Offensive: How China's Soft Power Is Transforming the World (New Haven: Yale University Press, 2007).

${ }^{2}$ Caroline Freund, "Reciprocity in Free Trade Agreements," World Bank Working Paper, no. 3061 (2003). The US has used FTAs to aggressively encourage prospective FTA partners to accelerate the pace of trade liberalization and domestic reforms. It is widely believed that reciprocity is a requirement for its trade agreements. See Ann Capling, All the Way with the USA: Australia, the US and Free Trade (Sydney: University of New South Wales Press, 2005). Robert Zoellick, "Unleashing the Trade Winds," The Economist, 7 December 2002. Jeffrey J. Schott, "Assessing US FTA Policy," in Free Trade Agreements: Us Strategies and Priorities, ed. Jeffrey J. Schott (Washington D.C.: Peterson Institute, 2004). I. M. Destler, American Trade Politics, 3rd ed. (Institute for International Economics, 1995).

${ }^{3}$ Krasner argues that openness in the world economy is most likely to occur during the ascendancy of a hegemonic state to utilize its economic advantages. Stephen Krasner, "State Power and the Structure of International Trade," World Politics 28, no. 3 (April 1976).

${ }^{4}$ Robert Pahre, Leading Questions: How Hegemony Affects the International Political Economy, Michigan Studies in International Political Economy (Ann Arbor: University of Michigan Press, 1999).
} 
increase in the IMF "in order to ensure the credibility and legitimacy of the Bretton Woods Institutions". 5

China has learned in the past decade, in particular from the FTA with ASEAN, that economic cooperation can help 'bind' countries together strategically, and therefore it has welcomed proposals of trade or financial arrangements from countries that China sees as strategic partners or those that China seeks to strengthen political relations with. China's FTA talks with Pakistan, Chile, South Africa, and Iceland may not make much economic sense because of the small size of their markets, but to these states, they at least represent the friendship or goodwill between two governments. Upon the foundation of 'bound relationships', the Chinese government feels more sure that certain benefits will be provided by the partner countries, either a peaceful neighbouring environment, the stable supply of raw materials or access to crucial marine routes.

When the political motivation is strong enough, it sometimes overrides economic costs. That happens when the leadership is strongly committed to the achievement of cooperation or when the domestic policymaking process is led by the Ministry of Foreign Affairs, as was the case during the initial stage of the CAFTA when China voluntarily opened up agriculture to ASEAN. However, the significance of political motivation behind China's foray into regional economic cooperation does not mean that China is not pragmatic in economic terms. There are evident national economic interests in most cases; and, as will be discussed later, the state's concern over domestic economic interests can largely constrain what it can offer to other countries.

\section{Economic interests}

China's attitude towards regional economic cooperation has often been instrumental. Chinese policymakers have not treated regional economic cooperation as opportunities for enforcing domestic reform or as a building bloc for global economic liberalization; nor have they aimed at deep economic or political integration among regional members as found in the

\footnotetext{
5 "The Joint Ministerial Statement of the $8^{\text {th }}$ ASEAN+3 Finance Ministers' Meeting", Istanbul, Turkey, 4 May 2005.
} 
EU. Rather, China has used regional economic cooperation to promote several national economic interests.

First, China seeks to expand trade through FTAs; especially for officials at MOFCOM, the increase of export volume has been regarded as an indicator of their work achievement. China tries to diversify and 'lock in' future export markets in view of setbacks it has met after the WTO accession in major markets in the US, Japan and EU, which have launched numerous trade disputes against China and urged China to appreciate the RMB. China seeks to establish FTAs with countries in every continent (for example, ASEAN, Australia, South African Customs Union, India, Iceland and Chile) in the hope that they would be an avenue for Chinese products to enter the markets there, if rules of origin are lenient enough, and that they would prompt non-partner countries to propose FTAs to China in order not to be marginalized from the Chinese market.

Second, because China feels disadvantaged by the status it had to accept as part of its accession negotiations for the WTO as an Economy in Transition for 15 years in anti-dumping cases, it asks for recognition of Market Economy Status from its FTA partners. This has usually been a precondition to starting formal negotiations, as was the case with Australia. China also hopes the recognition of some developed countries of its market economy status would propel other major WTO members like the US and EU to follow suit because they would then be in a weaker position to oppose the assessment of other market economies.

Third, China likes to conduct FTA talks with resource-rich countries (such as Australia, ASEAN, Chile, South Africa, and the Gulf Cooperation Council) in order to attempt to guarantee 'stable' - meaning long-term, stably-priced - supply of energy and resources from their governments, dismissing the question whether the partner country's government could direct the business activities of resources companies.

Fourth, China hopes to obtain information on international economic transactions through regional cooperation in particular in finance, ${ }^{6}$ although it is questionable whether China is ready to release its own information.

\footnotetext{
${ }^{6}$ The same motivation has been identified in China's participation in global economic institutions. See Harold K. Jacobson and Michel Oksenberg, China's Participation in the IMF, the World Bank, and GATT:
} 
Although Chinese policymakers claim that participating in regional trade and financial cooperation is an important channel to 'propel reform and development through opening', which helps China prepare for liberalization on a wider scale, using FTAs or regional financial cooperation to enforce domestic reform has not been a motivation of the government. Rather, China has been very conservative towards such 'experiments' and comfortable only with granting preferential treatment to regional partners under the existing domestic system. China is not willing to include significant chapters on behind-the-border issues (such as intellectual property rights, government procurement, SPS and TBT issues) in FTAs, or to subject the domestic financial system to regional scrutiny. The WTO membership was in a sense used by the Chinese leadership to impose reforms on difficult domestic sectors and to lock in reform in the future. ${ }^{7}$ Regionalism, in contrast, is pursued to 'lock in' the international economic opportunities for Chinese domestic actors under China's given economic conditions.

\subsection{Domestic interests}

Even though the Chinese state is widely believed to have much more autonomy than that found in many other countries, China should not be treated as a unitary actor in international political economy, even if economic diplomacy has been conducted in a secretive manner. The findings in this thesis support the observations made by Lampton that China's foreign policymaking has been in the process of 'corporate pluralization' and decentralization, particularly if the policy is associated with economic interests. ${ }^{8}$ Various domestic interests, to different degrees, have influenced the state's decision, sometimes significantly constraining the

Toward a Global Economic Order (Ann Arbor: The University of Michigan Press, 1990), 70. Margaret M. Pearson, "The Case of China's Accession to GATT/WTO," in The Making of Chinese Foreign and Security Policy in the Era of Reform, 1978-2000, ed. David M. Lampton (Stanford: Stanford University Press, 2001), 357.

${ }^{7}$ Shaun Breslin, "Reforming China's Embedded Socialist Compromise: China and the WTO," Global Change, Peace and Security 15, no. 3 (October 2003). Pearson, "The Case of China's Accession to GATT/WTO." Joseph Fewsmith, "China and the WTO: Politics Behind the Agreement," NBR Analysis 10, no. 5 (December 1999). Nicholas R. Lardy, Integrating China into the Global Economy (Washington, D.C.: Brookings Institution Press, 2002), 9-22.

${ }^{8}$ David M. Lampton, "China's Foreign and National Security Policy-Making Process: Is It Changing, and Does It Matter?," in The Making of Chinese Foreign and Security Policy in the Era of Reform, 1978-2000 ed. David M. Lampton (Stanford: Stanford University Press, 2001). Similar views are held by Pearson, "The Case of China's Accession to GATT/WTO." Harris, in Stuart Harris, "Globalisation and China's Diplomacy: Structure and Process," in Working Paper (Canberra: Department of International Relations, Research School of Pacific and Asian Studies, Australian National University, 2002). And by Shirk, in Susan L. Shirk, How China Opened Its Door: The Political Success of the PRC's Foreign Trade and Investment Reforms, Integrating National Economies (Washington, D.C.: Brookings Institution, 1994). David Zweig, Internationalizing China: Domestic Interests and Global Linkages, Cornel Studies in Political Economy (Ithaca: Cornell University Press, 2002). 
state's autonomy to pursue national interests. Although Chinese 'interest groups' do not take the same form as lobby groups or independent industrial associations in Western countries, industrial sectors are becoming increasingly vocal about their particular interests through industrial-line ministries or national commissions. Some industrial associations have started to show interest in FTAs, but they are not independent enough to have a strong voice in Chinese politics.

In the cases of trade policymaking, the interest groups have been organised mostly along the lines of industries as predicted by the Ricardo-Viner model, rather than classes (owners of capital and owners of labour) as predicted by the Heckscher-Ohlin model. Export-oriented industries are supportive of trade liberalization under FTAs, such as manufacturing in both cases of the CAFTA and the AUCFTA, while import-competing industries are against it, such as agriculture in those two cases, and services in the AUCFTA. The interests of farmers were represented by the Ministry of Agriculture because there is no farmers' union or organization in China, and the Ministry, like that in most other countries, is protectionist for its own reasons career prospects for officials and profits from existing rents for the bureaucracy. Nor is there an independent labour union or trade union to represent workers, whose interests can be expressed only through ministries, national commissions or the companies they work for. Whether the owners of capital in China welcome investment liberalization depends on the sector as well: the resources, telecommunication, banking and other services sectors are against liberalization for fear of competition and losing monopoly profits, while there is no concern expressed by manufacturing interests. On the contrary, the central and local governments in China have welcomed investments in manufacturing in the hope of obtaining capital, managerial experience and advanced technology. In this sense, the Ricardo-Viner model is more accurate than the Heckscher-Ohlin model in describing the trade policy coalitions in China-trade policy coalitions have been mostly formed along industrial lines rather than factor or class lines.

The case studies in this thesis support the adage that the government often picks prospective losers rather than winners. It seems that Chinese central policymakers think that imposing costs on domestic interests is politically more sensitive than the reduction of potential benefits. Moreover, sectors in China with defensive interests from the proposed FTAs are more 
vocal than those with offensive interests in expressing themselves: agriculture and services have a louder voice than manufacturing because they are clearly aware of the potential costs under the FTAs, while manufacturing sectors are not certain of future gains as they are not familiar with the potential new markets and the administrative cost to obtain certificates of rule of origin is often significant vis-à-vis the preferential tariff treatment, especially since the FTAs that China has negotiated to date are not with major trading partners. Besides, agriculture and services have not been liberalized to the same extent as manufacturing under the WTO commitments and during government restructuring in 1998 or 2003. More specifically, the agricultural and services regulators retained more power on industrial policy than their manufacturing counterparts; a number of industrial-line ministries have been downgraded to national business associations as well. As a result, at state-level meetings on FTAs where most policies on FTAs have been coordinated, agriculture and services sectors are each represented by an individual state-level ministry or commission, while the mostly decentralised and privatised manufacturing sectors are at best represented by MOFCOM and the State-Owned Assets Supervision and Administration Commission and the NDRC, the latter two being known for their conservative attitude towards liberalization. Partial reform in China has not only created rents for regulators of agriculture and services as Hellman argues, ${ }^{9}$ but also provided protectionists with reasons for opposing further liberalization, drawn from painful experiences without acknowledging possible benefits during past liberalization, as was the case for agriculture in both the CAFTA and the AUCFTA policymaking. In a political environment that increasingly stresses social welfare vis-à-vis purely economic growth, the Chinese state has to pay more attention to the losers, in particular if the issue is related to farmers and ethnic minorities. As will be discussed later, the different levels of collective action between these winners and losers also result from their different institutional structures.

\footnotetext{
9 Joel S. Hellman, "Winners Take All: The Politics of Partial Reform in Postcommunist Transitions," World Politics 50, no. 2 1998). For the analysis of partial reform in China, see Shaun Breslin, "Paradigm Shifts and Time-Lags? The Politics of Financial Reform in the People's Republic of China," Asian Business \& Management 2 (2003). Susan L. Shirk, The Political Logic of Economic Reform in China, California Series on Social Choice and Political Economy; 24 (Berkeley: University of California Press, 1993). Barry Naughton, "China's Transition in Economic Perspective," in The Paradox of China's PostMao Reforms, ed. Merle Goldman and Roderick MacFarquhar, Harvard Contemporary China Series; 12 (Cambridge, Mass.: Harvard University Press, 1999).
} 
Because the employment of ministerial and local officials in China is still largely decided at the central level, domestic industrial or local interests sometimes succumb to national interests, if there is direct pressure from the leadership or the State Council. The central government may 'buy off' local governments in the form of financial aid or the right to hold international trade fairs, in exchange for the latter's explicit support for central policies that may harm local constituencies, as was the case with farmers in Yunnan and Guangxi Provinces under the CAFTA. The Ministry of Agriculture, and Yunnan and Guangxi provincial governments did not oppose CAFTA openly because there was clear pressure from Premier Zhu Rongji on them to oblige, but when similar pressure is lacking in the case of the AUCFTA, the Ministry and provinces like Xinjiang and Inner Mongolia speak loudly against liberalization, forcing the trade negotiators to take a conservative stance.

\section{Ideas}

Various ideas have entered China's policymaking on regional economic cooperation and, through the policymaking institutions, influenced the stance China takes at international arenas. As will be discussed in more detail below, consensus on some issues has been formed among Chinese policymakers, directing their decisions towards regional economic cooperation in coherent ways, in particular in defining the national interest and the means to realise it, while different views exist on other issues and compete with each other for the strongest influence on policy.

The consensus among policymakers has had a significant impact on their decisions regarding some issues of national interest in regional economic cooperation, such as the momentum of regionalism, what China's national identity is, the proactive diplomatic approach, and the lessons from the WTO. It has sometimes been formulated from China's past experiences in international interactions, and sometimes facilitated by a strong discursive environment at domestic and international levels.

The realization that regionalism has become an inevitable trend in the world, and in East Asia in particular, prompted China to join the flow in order not to be excluded from a major means of international distribution of political economic interests, and in order to foster the image that it is a responsible player in the region. Like observers in other East Asian countries, 
Chinese policymakers and scholars understood the development of regionalism in Europe and North America as a sign that regionalism would expand in the world, and that East Asian countries would be disadvantaged vis-à-vis those countries in global political economy if they did not form a group of their own. The momentum of East Asian regionalism built up after the Asian financial crisis convinced Chinese policymakers that China should participate in this trend, or otherwise China would be outwitted by Japan and lose respect from ASEAN. Although tentative and symbolic at the beginning, the regional discursive environment for furthering East Asian trade and financial cooperation was so strong that China's participation has become more committed and substantial over time, as can be seen from its earlier preference for bilateral FTAs to later proposing a Northeast Asian FTA, as well as its increasing initiative for upgrading the CMI. Initially aimed at alleviating ASEAN's worry of the 'China threat', China's regional economic diplomacy is increasingly led by the aspiration for regional leadership and the desire to create the image that it is a responsible regional player, as part of its global pursuit of such an image. Moreover, the idea that economic cooperation could strengthen strategic relationships came from China's experience in its first FTA, the CAFTA, and from learning from the European story, and motivated China to pursue many other economic arrangements.

The understanding of China's national identity, or the one Beijing would like to promote, has significantly influenced China's position on regional economic cooperation. The transition in identity in the late 1990s from a victim that only seeks economic development to an international player that contributes to world order has propelled China to take a more proactive role in international institution building. The over-arching identity that China would like to construct is as a responsible great power, which in the regional context entails contributing to regional peace and development, participating in regional rule making and institution building, as well as giving more to and taking less from smaller countries. In particular, China endeavours to establish authority by setting moral paradigms and providing material benefits, which might differ from those of other great powers in history that have exploited the power imbalance for their own material gains. Chinese refers to this difference as one between 'wang dao' [the way of being a leader] and ' $b a$ dao' [the way of being a hegemon]. It may resemble China's Central Kingdom mentality in the Tang Dynasty, but it does not mean that the Chinese government now 
thinks a 'modern tributary system' is desirable or plausible. Such a strategy has been used mostly towards developing countries, because China portrays itself as a representative for developing countries and for East Asia at global arenas. Towards developed countries, however, China holds on firmly to its material interests and seeks the moral high ground if possible. It remains to be seen whether China can keep walking the road of wang dao rather than ba dao as it increasingly needs more markets for exports and more raw materials from developing countries.

Another important consensus in Chinese diplomacy that was formed at the beginning of China's foray into regionalism in the late 1990s and continues to impact on China's economic diplomacy is the adoption of a proactive diplomatic approach. In place of 'tao guang yang hui' [hide the sharpness while preserving strength], Chinese policymakers now emphasizes ' $y u$ shi ju jin' [advance with the trend of time] and seek to play an influential role in institution building both at the global and regional levels. This was based on more confidence in national power and in their diplomatic skill, as well as the lesson drawn from international organisations such as the WTO and IMF that taking part in international institution building is crucial to China's national interest. $^{10}$

Apart from the importance of participating in international institution building, membership in the WTO also helped Chinese policymakers and domestic interests to learn a few economic lessons. One is that China's status as an economy in transition puts China in a 'disadvantaged' position in anti-dumping trade disputes, and therefore China tries to address this problem by requesting the Market Economy Status from FTA partners, while presuming that FTA partnership would reduce the propensity of the partner country to raise trade disputes to the WTO. Another lesson is that opening the economy to competition does not necessarily enhance the productivity of agriculture. The domestic agricultural sector has come to this conclusion, and uses it as an excuse to avoid further liberalization under FTAs where possible. Chinese trade policymakers have increased sympathy for agriculture as well, as they have witnessed how other countries have vehemently protected agriculture at the WTO. Besides, the

\footnotetext{
${ }^{10}$ Jacobson and Oksenberg, China's Participation in the IMA, the World Bank, and GATT. Lardy, Integrating China into the Global Economy, 157. Ann Kent, Beyond Compliance: China, International Organizations and Global Security, Studies in Asian Security (Stanford: Stanford University Press, 2007).
} 
Chinese government has been pushing for a self-sufficiency policy that seeks to ensure 95 percent of the supply of grains is self-sufficient, in order to guarantee China's food security.

Chinese perspectives on some other issues are not so unanimous or straightforward, but carry contradictory or changing answers to certain questions, such as whether regionalism should contribute to globalization, how to balance between economic growth and development, between international interdependence and sovereignty, and between the state and the market approach in conducting economic diplomacy.

\subsection{Should regionalism contribute to globalization?}

Until the late 1990s, Chinese policymakers regarded regionalism as detrimental to multilateral global economic cooperation or globalization. However, the developments in China, in Asia and elsewhere in the world as mentioned above propelled China to embark actively on regionalism. The important question here is whether Chinese policymakers think that China should ensure that its participation in regionalism contributes to globalization.

In its rhetoric the Chinese government says regionalism and globalization, or multilateralism, are complementary to each other in China's economic diplomacy as well as in international trade liberalization. In economic diplomacy, China's activity in regionalism originated partly from the disappointment that the accession into the WTO has not brought as much trade expansion as China had expected because of numerous trade disputes against China. It seems that China has taken a rather 'defensive' position at the WTO towards further liberalization of the Chinese economy while calling for developed countries to make more concessions. In contrast, China seems quite 'offensive' in forging FTAs, although most of them have been proposed by the other party. Moreover, the capacity of the trade bureaucracy is overstretched; the MOFCOM officials in charge of WTO affairs were designated to negotiate the FTAs with Australia and New Zealand, ${ }^{11}$ and possibly other future 'complicated' FTAs with developed countries.

In international trade liberalization, China does not seek to make its FTAs comply strictly with WTO rules. Chinese policymakers believe that under the Enabling Clause of the WTO, China does not have to make sure its FTA with another developing country is a comprehensive

\footnotetext{
${ }^{11}$ The New Zealand-China FTA was signed on 7 April 2008.
} 
single undertaking. As to agreements that involve an industrialized economy like Australia, they believe China does not have to liberalize trade to the same extent as its partner country. They interpret GATT Article XXIV that FTAs should cover 'substantially all trade' as "FTAs should try to liberalize as much trade as possible", while pointing out that few FTAs in the world were really free. As mentioned above, the Chinese government does not seek to use regional agreements to impose domestic reforms, which are needed if China is to liberalize further under the WTO. Many of China's FTAs carve out significant sectors from tariff reduction for China and for its partner country, and have a long implementation period. They are exclusive and discriminatory in nature, have varied rules of origin, and therefore it is questionable that they would come together among themselves or with other FTAs into a multilateral free trade agreement.

As for finance, China seems to heed more the opinions of the IMF and World Bank on regional issues than it does the WTO, in part because of its need for the latter's financial assistance for domestic development. China's position on the relationship between regional and global financial cooperation exhibits some inconsistency. On the one hand, for the security of its own financial loans, China has preferred close linkage with IMF conditionality for the CMI swap arrangements. Although China opposes the imposition of conditionality of the IMF loans on developing countries for its insensitivity towards local development needs, close linkage of the CMI with the IMF means that the CMI has similar conditionality for regional loans. This makes China feel safe that its prospective loans under the CMI would not be exploited by regional members or generate moral hazard problems that the IMF also seeks to avoid. However, it was largely because of the strict conditionality of the IMF that regional members thought that the global financial institution was not a reliable source for swift support during financial crises, and they sought to have a regional source of rescue of their own without the types of constraint the IMF imposes. On the other hand, China enjoys being part of an East Asian group in calling for a change of voting power at international financial institutions. Undoubtedly China needs to resolve the inconsistency between these two positions if it wishes to play a bigger role either in the region or at the global stage. 


\subsection{Growth vs. Development}

The change from emphasis on economic growth by the second and third generations of the Chinese leadership to a concern with balanced and stable development by the fourth generation has had a significant impact on China's policies towards regional economic cooperation. Notably, Hu Jintao and Wen Jiabao are not as forceful as Zhu Rongji in promoting economic liberalization, but are more careful about potential domestic economic costs or risks, in particular those associated with social tensions such as unemployment, income inequality, and ethnic minorities' and farmers' welfare. Chinese policymakers have also started to reflect on the growth model of the Chinese economy in the past decade that relies heavily on exports and foreign investment, in particular when Chinese cheap manufactured goods are losing competitiveness in the global market and inefficient domestic production is a black hole for energy and resources. ${ }^{12}$ The rhetoric of the government has now turned to sustainable and balanced development, meaning a focus on addressing social welfare and regional disparity, preserving the environment and enhancing the competitiveness of domestic industries. China has been less willing in its recent regional negotiations, compared with the WTO accession or the CAFTA negotiation, to make concessions in agricultural trade, or to invite foreign competition in sectors that are considered the 'foundation' for the national economy, such as banking, telecommunication, transportation, energy and resources.

\subsection{Interdependence vs. Sovereignty}

China has accepted international interdependence since 1978, but to what extent and at what pace China should liberalize further remains a heated debate. This was increasingly so after the Asian financial crisis and the WTO accession, from which China witnessed or experienced the negative impacts of globalization on national economies. Some, represented by MOFCOM, advocate neoliberal economic ideas, believing competition promotes productivity, and that China is strong enough to be a party to legally-binding international agreements. Others, such as the central bank, the NDRC and most industrial ministries, criticise the neoliberal economic ideals of the Washington Consensus and emphasize economic sovereignty. They

\footnotetext{
${ }^{12}$ Shaun Breslin, "The Politics of Chinese Trade and the Asian Financial Crises: Questioning the Wisdom of Export-Led Growth," Third World Quarterly 20, no. 6 (1999).
} 
argue that ensuring economic security and cultivating national industries are the most important priorities for present-day China in a tumultuous international environment, and therefore China should avoid trade or financial arrangements that might threaten domestic infant industries or the state's control over key economic policies. As will be discussed later, which school has more influence over state policies depends heavily on the policymaking institutions. ${ }^{13}$

\subsection{State vs. Market}

Perhaps because FTAs and regional financial cooperation take the form of intergovernmental arrangements, and because of the legacy of the planned economy, Chinese policymakers stress the role of the state over the market in the policymaking on those issues. The government does not carry out substantial surveys to gather business opinions on potential FTAs, which has hindered its ability to obtain reliable information for effective decision making. This is because for several industries (manufacturing and many services sectors) there are no individual ministries directly in charge, and for other industries information provided by ministries is often quite problematic either for lack of bureaucratic capacity or for insufficient attention they pay to regional economic cooperation. As Chinese MOFCOM and Australian negotiators complained, information provided by the Chinese ministries was vague and sometimes contradictory in the AUCFTA negotiations. Nor does the Chinese government run pro-FTA advocacy programmes in China or in the partner country, which arguably might have created a more congenial environment for difficult negotiations. The Chinese government's perception that the state has the final say in economic decision making has also caused China to underestimate societal pressures on partner governments. It has also led it to make requests deemed impossible by a market-economy country, such as to include a clause on energy pricing and supply in the AUCFTA.

The emphasis on state over market in Chinese perspectives on regional economic cooperation does not mean that China has a simple highly-centralised policymaking institution. In fact, policymaking is fragmented at the state level; central policymakers have been subject to

\footnotetext{
${ }^{13}$ Similar argument is made by others with regards to China's policymaking on the WTO accession and the reform in the late 1990s, see Lardy, Integrating China into the Global Economy, 9-22. Pearson, "The Case of China's Accession to GATT/WTO." Hui Feng, The Politics of China's Accession to the World Trade Organisation: The Dragon Goes Global (London and New York: Routledge, 2006).
} 
domestic pressures to different degrees, depending on how well they are insulated and how much collective action there is within each domestic interest group. These institutional features of policymaking have largely determined which of the above-mentioned interests or ideas would be expressed in national policies.

\section{Institutions}

The theoretical framework of historical institutionalism has helped this study to achieve an understanding of China's policymaking on regional economic cooperation, by highlighting the role of institutions in shaping and structuring the interactions among policy preferences. In particular, this study's focus on three features of institutions - the degree of insulation of the central policymaker from domestic pressure, the degree of collective action within each domestic interest group, and the degree of fragmentation of state power-has helped explain China's different stances in three cases: the CAFTA, the AUCFTA and East Asian financial cooperation.

\subsection{Insulation}

This study supports the argument that the propensity of a country to engage in international cooperation or liberalization is not narrowly decided by the regime type - whether it is a democracy or an autocracy — or solely by the relationship between the executive and legislative branches. ${ }^{14}$ Rather, it is essentially determined by the degree of insulation of the central policymakers from domestic pressure more broadly. Therefore, it not only varies among democracies and among autocracies, but also varies in a country's policies at different times and on different issues. Certainly, the policy preferences of central policymakers and other domestic actors matter as well; however, central policymakers are more likely to define their policy preference based on their perception about what is good for the country than domestic sectoral and local actors, who are more inclined to pursue self-interest in material gains and career prospects. Therefore, the degree of insulation of the central policymakers is particularly

\footnotetext{
${ }^{14}$ Helen V. Milner, "The Political Economy of International Trade," Annual Review of Political Science 2 (1999). Hiscox, "The Domestic Sources of Foreign Economic Policies." Katzenstein, "International Relations and Domestic Structures." Edward D. Mansfield and Marc L. Busch, "The Political Economy of Nontariff Barriers: A Cross-National Analysis," International Organization 49, no. 4 (Autumn 1995).
} 
important in foreign economic policymaking. The insulation could be achieved not only in an autocratic regime, but also by the direct participation of the political leadership, by delegating decision making power to an agency, or by controlling information.

In the case of the CAFTA policymaking, the central policymakers were quite insulated. It was proposed by Premier Zhu Rongji with few domestic actors knowing in advance. Zhu's strong commitment continued to propel the policymaking process on the CAFTA during his tenure because few officials in China would dare to openly challenge the authority of the leadership. After initiation, the decision making power was allocated to the Ministry of Foreign Affairs, which was not in direct contact with domestic economic actors-including industries and local governments - and commanded high authority in China's diplomacy formulation. The Feasibility Study was conducted in a secretive manner; the government appointed only a few scholars from quasi-governmental academic institutions, and the draft report of the study had to go through government review before it was released to the public. After the Framework Agreement was signed, the decision power was allocated to MOFTEC (and later MOFCOM) to 'implement' that agreement, which actually meant formal FTA negotiations. At this stage, MOFTEC did not enjoy as much insulation as MFA had, because MOFTEC had equal status with other industrial ministries and with local governments and had working relationship with them on economic matters. As the lead agency and policy coordinator, MOFTEC convened working meetings with relevant ministries and provincial governments to hear their views. MOFTEC showed more concern for China's economic benefits than MFA had, seeking to open the partner countries' markets and to protect some sensitive sectors. Still, because the CAFTA was China's first FTA with another country, domestic industrial sectors and local provinces were not familiar with its implications. Even though some had concerns over the potential costs to agriculture, they were silenced forcefully by the Premier at secretly-held meetings, or kept quiet because they were aware of the strong political message behind it. Importantly, MOFTEC had the power to report directly to the State Council if there was any difficulty in coordinating domestic interests.

Compared with the CAFTA policymaking, the central policymakers in China's policymaking on the AUCFTA were much less insulated. There was political goodwill from the 
leadership, but its commitment is not as strong as it was for the CAFTA because of political strategic reasons, and the MFA does not directly participate in policymaking. Compared with the previous generation of leadership, the Hu-Wen leadership is under more domestic pressure to care for social welfare because social tensions have escalated and become more open, which cast doubt on the government's previous reform and liberalization programmes. The economic policies of the current central government are under more domestic scrutiny, by the National People's Congress and by 'new-lefties' in the Communist Party.

The Chinese government could not control the information regarding the Feasibility Study of the AUCFTA as it did in the case of the CAFTA. Chinese scholars were not able to dominate the joint feasibility study with Australia, and the Chinese government dismissed the draft report as overestimating benefits and underestimating costs for China, although it did not have the capacity to carry out a reliable study on its own.

Although MOFCOM was designated as the lead agency, it only had the authority of a negotiator on behalf of industries but not the authority of a coordinator. In other words, MOFCOM is expected to represent the interests of industries at international negotiations, and thus their proposals for the negotiation agenda need the endorsement of relevant industrial ministries or national commissions, which is often very difficult to achieve. Unlike the case of the CAFTA or the WTO accession, MOFCOM is not expected to rely on the State Council to solve problems in domestic coordination. As a result, domestic interest groups, represented by ministries and local governments, took the opportunity to speak openly against further liberalization beyond the WTO levels under the proposed FTA.

In a word, the central policymakers in China on the AUCFTA do not enjoy as much insulation as their predecessors did on the CAFTA, and it has contributed to China's much more conservative stance on the AUCFTA than that on the CAFTA.

China's finance policy makers are generally more insulated from domestic pressure than trade policy makers. Because finance requires a high level of expertise and it is immediately related to national economic security, policymaking is usually carried out with high confidentiality and caution, especially after the lesson of the Asian financial crisis. Insulation of central policymakers is easily achieved by controlling information. Policy discussions on 
regional financial cooperation have only been conducted among a small circle of actors: the central bank, the Ministry of Finance, the Ministry of Foreign Affairs, and a few invited scholars from the CASS. The direct involvement of the MFA, in particular in the primary stage of endorsing policy initiatives, dictates that China's policies towards East Asian financial cooperation have been heavily dominated by politico-strategic considerations. The priority that the central bank and the MOF place on domestic financial stability rather than international cooperation determined that China adopted a conservative position towards deep regional financial cooperation that would compromise China's monetary or financial sovereignty. Although trade and finance are closely related in regionalism, and some MOFCOM officials have expressed hope for further progress in East Asian financial cooperation, MOFCOM does not participate or have any power in China's policymaking on regional financial cooperation. Considering that the potential impact of financial cooperation is more on overall national economy rather than on specific domestic sectors, there has been no dissent from domestic industries or local governments. The Chinese scholars hold a more liberal view towards regional financial cooperation and integration than government officials do, but they seem to have been more influenced by the views of the government, than the government by scholars. The officials, whether they are foreign policy or economic policy institutions, seem to easily dismiss economic advice from scholars that is not coherent with strategic considerations or seems too radical for the domestic economy. Still, it is notable that because of the significant role of second-track dialogue and studies at the regional level in East Asian financial cooperation, the scholars in the region have played an indirect role in creating a regional discursive environment that promotes further steps towards regional institution building for financial cooperation, and to some extent that has propelled the Chinese government to follow the regional trend.

\subsection{Collective action}

How much pressure domestic interest groups exert on central policymakers is largely determined by the degree of collective action within each group, which heavily depends on the group's institutional structure. Since there is no domestic group involved in the finance policymaking, here I will focus on trade. 
Because there are few independent business associations in China, domestic interests need to be expressed through ministerial agencies or local governments. Agriculture and several other services industries, such as telecommunication, banking, transportation, legal services and construction, have their respective ministries or national commissions; foreign investment policies are in the charge of the NDRC. Reform has only been partial in these sectors and the government agencies in charge of these sectors have retained significant regulatory power; any further reform needs their consent. These agencies would like to retain their power over the national economy, and for some, to retain the rents for the bureaucracy generated from such power and the huge profits for the sector from administrative monopoly. Therefore these sectors have the institutional structure to amount a high degree of collective action when their existing interests are threatened by liberalization under FTAs.

Manufacturing, on the other hand, has been significantly decentralised or privatised because it has been the central target of market reforms in the past decade, in particular in the government restructuring in 1998 and 2003, when several industrial ministries, including light industries, coal, petrochemical and machinery, were downgraded to business associations. Indeed, Chinese manufacturers initially did not have much idea what benefits the CAFTA could bring to them, and the markets in most of China's FTA partner countries are relatively small. However, awareness about FTAs in manufacturers has increased, and for manufacturers of oversupplied products in the domestic market, the potential benefits from the prospective FTAs with ASEAN and Australia were still important. A significant obstacle for them to express their interests was that the state's regulatory power in these sectors was also greatly diminished, from management through ministries, to guidance through cross-industry national commissions, and naturally the industrial business associations do not enjoy as much clout in the central policymaking as the ministries did before. This is especially so in the policymaking on FTAs because much of the policy coordination has been done at working meetings or through correspondence with 'co-signatures' among ministerial government agencies. Indeed the awareness of manufacturing industries about the potential impacts or benefits of proposed FTAs was hindered by their unfamiliarity with FTAs at the early stage, but that unfamiliarity was the same for other sectors, and in fact, their awareness grew during the implementation of the 
CAFTA. Due to the decentralised institutional structure, however, manufacturing has yet to develop a collective opinion on the potential impacts or benefits of proposed FTAs. Even though some manufacturing sectors would benefit from proposed FTAs, they did not take collective action to pressure the central policymakers to achieve this goal. As a result, the negotiators from MOFCOM were under much more pressure from protection-seeking industries than from export-oriented industries.

The role of local governments is much less significant than ministerial agencies in China's policymaking on regional economic cooperation. Local bureaus of commerce need to report both to the local government and to MOFCOM, and they view their role mainly as one of implementation. There has been concern over agriculture expressed by provincial governments in both cases of the CAFTA and the AUCFTA. In the case of the CAFTA, the two major provinces affected by agricultural imports from ASEAN, namely Guangxi and Yunnan, initially reported the impacts to MOFCOM, and were certainly silenced by the liberal MOFCOM. More importantly, the central government decided to 'compensate' these two provinces with trade fairs or infrastructure programmes. Besides, because of geographical proximity to ASEAN, these provinces could benefit from exporting manufacturing products to ASEAN, and from utilizing cheap labour and the uncompetitive local markets in ASEAN if Chinese companies formed transnational production networks with ASEAN countries. The two local governments were then engaged in competing for those opportunities instead of complaining about central policies. In the case of the AUCFTA, the provinces to be affected are too numerous for the government to carry out such compensation programmes. And, because of the distance between China and Australia and associated costs, as well as the higher labour cost and competitive market in Australia, it is more difficult for these provinces to benefit from production networks. As a result, opposition from local provinces was much stronger against the AUCFTA than that against the CAFTA.

\subsection{Fragmentation}

The more fragmented policymaking power is at the state level, the more it is difficult for the government to set the agenda for international cooperation. This study supports other authors' observation that China's policymaking in the reform era is quite fragmented, and finds 
substantial evidence in support of the concept of 'fragmented authoritarianism' used by Lieberthal and Lampton. ${ }^{15}$ However, this study finds that the degrees of fragmentation and authoritarianism in China's policymaking vary across issue areas and across time, with the potential to lead to significant change in the policymaking structure. In particular, China's trade policymaking has become more fragmented at the state level since 2003. Although Zhu Rongii's institutional reform in 2003 to combine domestic and foreign trade agencies together was meant to strengthen the power of MOFCOM in promoting liberalization, there is consensus among Chinese officials and their foreign counterparts that MOFCOM's power declined from the level enjoyed by MOFTEC, which was already increasingly constrained by other ministries in negotiations for the WTO accession. ${ }^{16}$ What happened was the fragmentation of trade and industrial policymaking power among MOFCOM, the NDRC, and industrial ministries or commissions. The NDRC's former body, the State Planning Commission, was meant to be cut down in 2003 from a powerful apparatus of the planned economy to an advisory institution. However, under the Hu-Wen government, the NDRC is playing an increasingly significant role in making industrial policies, as well as foreign trade and investment policies. MOFTEC had sole authority over foreign economic policies, but MOFCOM needs to take care of the domestic market as well and therefore needs to take into consideration the opinions of NDRC and industrial ministries on economic policies. Because the NDRC has inherited a conservative view towards liberalization from its former body, the tension between MOFCOM and NDRC has made Chinese foreign economic policymaking become even more fragmented.

As reflected in the case studies, it was much easier for China to set the negotiation agenda for the CAFTA than it has been for the AUCFTA. In the case of the CAFTA, the policymaking was first led by MFA without being challenged by any other state agency because MFA has the sole authority over foreign policy making, and MOFTEC was clearly designated to assist. After November 2002 when MOFTEC took over the leading role, it still remained unchallenged because there was clear delineation between foreign and domestic economic policymaking

\footnotetext{
${ }^{15}$ Shirk, The Political Logic of Economic Reform in China. Margaret M. Pearson, "China's WTO Implementation in Comparative Perspective: Lessons from the Literatures in Trade Policy and Regulation," The Review of International Affairs 3, no. 4 Summer 2004). Kenneth Lieberthal and David M. Lampton, Bureaucracy, Politics, and Decision Making in Post-Mao China, Studies on China; 14 (Berkeley: University of California Press, 1992).

${ }^{16}$ Pearson, "The Case of China's Accession to GATT/WTO." Feng, The Dragon Goes Global.
} 
powers, with the former backed by the Premier. However, in the case of the AUCFTA, MOFCOM could not take independent action without the endorsement of the industrial ministries or the NDRC, which has remained quite detached from the negotiations. As the Australian negotiators complained, Chinese policymaking power is so fragmented and complicated that they sometimes found inconsistent agendas for trade negotiation and contradictory economic policies from different Chinese ministries.

While the CAFTA has mainly covered 'border issues' - tariffs and quotas - the AUCFTA negotiations also cover behind-the-border issues such as intellectual property rights, government procurement, transparency and national treatment for foreign investments. To realize an FTA that incorporates these issues would require the cooperation of government institutions and local governments to implement these policies. Therefore, Chinese negotiators from MOFCOM need to take into consideration their opinions, in particular how plausible it was that the policies would be faithfully implemented, because government regulators are not willing to change domestic regulations to meet the needs of FTAs. That also causes the policymaking arrangements for the AUCFTA to be more fragmented than those for the CAFTA which has focused only on border issues. It remains to be seen how difficult it is for China and ASEAN to reach agreement on investments, but according to MOFCOM officials it has been more challenging than the negotiation on trade in goods.

The policymaking on finance is not as fragmented as that on trade, and therefore it is generally easy for Chinese representatives to take a unified position at international negotiations. The power is shared between the Ministry of Finance and the central bank, the People's Bank of China, and they share the policy priority of maintaining national economic stability and security. Therefore, they have been cautious about liberalising measures in regional financial cooperation that might compromise China's economic sovereignty or create opportunities for international speculators. They both believe the pace of international integration should be slower than that of domestic reform, rather than the opposite. There is only a nuanced difference between the attitudes of the two agencies towards regional financial cooperation: the MOF represents China at regional arenas on financial cooperation and would like to see cooperation pushed forward, while the central bank's conservative position on monetary policies has determined that the 
Chinese MOF does not have as much autonomy as some of its regional counterparts to make international commitments.

In summary, the three features of institutions - the degree of insulation of the central policymaker from domestic pressure, the degree of collective action within each domestic interest group, and the degree of fragmentation of policymaking power at the state level - are decisive factors in China's policymaking on regional economic cooperation: policymaking institutions with variations in these three features have produced different types of policies. Some of the variations are across issue areas such as trade and finance, and some are across time such as changes with the policymaking institutions on FTAs.

\section{Institutional Change}

The pattern and sources of institutional change are another concern in this study, because they are a major topic for theories of policymaking, including historical institutionalism.

\subsection{Resistance to change}

The findings of this study support the argument within historical institutionalist approaches that institutions have the tendency to resist change. Although the Chinese government has embraced the ideal of market economy, the legacy of the planned economy has been lingering within Chinese policymaking institutions. The regulatory agencies (such as agriculture, banking, telecommunication, securities, and cultural industries) are not willing to give up more power over the market beyond the level required by the WTO commitments. The NDRC has inherited the ideals and styles of the State Planning Commission, although it underwent severe restructuring. China's policymaking on regional economic cooperation has also remained at the state level without much participation by private sectors because the government retains the state-dominated approach towards national economic management. Also, although the sole authority of the central bank on monetary policies has constrained China's participation in regional financial cooperation, and domestic observers may have called for a more sophisticated structure of foreign exchange policy making, the central bank is not willing to share this power with the Ministry of Finance. 
China's market reform and liberalization have so far been propelled by forceful political leadership as well as by the incentives from the initial benefits of marketization. It is now more difficult for the Chinese government to push forward further reforms because partial reform has made some sectors like agriculture resent liberalization, and has helped some others gain political influence. Moreover, some have enjoyed huge economic profits from administrative monopolies and from the rents generated from particularistic policy discretion. Because monopoly and rents would be lost from complete liberalization while benefits from further liberalization are uncertain, government and business actors with vested interests in the status of partial reform are against further reform, and the costs arising from past liberalization have helped them gain political influence to impede further reform.

Institutions do change under certain circumstances, however. Three sources of institutional change can be identified from the case studies: institutional learning, the emergence of a new policy area, and the change in the composition of key actors.

\subsection{Institutional learning}

China started pursuing FTAs partly out of competition with other initiatives in East Asia, such as the possibility of Japan's offering an FTA proposal to ASEAN and the launch of the Korea-Japan FTA study group, and partly out of emulation of the EU and NAFTA. The format of the CAFTA was borrowed from the ASEAN FTA, and the structure of domestic policymaking has to some extent been taken from other countries as well. For instance, as in many other countries, the appointment of an expert group to carry out a Feasibility Study before starting formal negotiations has become an established institution for China's FTA policymaking. The government has learned to control the process of an FTA negotiation by accelerating or prolonging the feasibility study, and sometimes even by controlling the results of the study.

Another example is that when China started the first FTA - the CAFTA - the MFA was the lead agency because it was regarded as part of China's good neighbourly diplomacy. However, as China's experiences with FTAs grow, although FTAs are still an important part of China's economic diplomacy, MOFCOM is by default the lead agency from the beginning of 
FTA talks because China needs to conduct commercially meaningful dialogues with their foreign counterparts, which are all foreign trade agencies.

If an FTA negotiation covers a wide area of trade and investment that requires deep cooperation between the two countries' domestic institutions, it can provide an incentive for the two countries to streamline their domestic procedures in order to reduce transaction costs and policy loopholes. The proposed AUCFTA had the potential to align China's policymaking institutions on behind-the-border issues with those of Australia, because Australia requested China to do so in order to guarantee the benefits of an FTA. Before the two countries exchanged substantial offers and requests, they had gone through a lengthy process of familiarization with each other's domestic systems. The Chinese government and businesses regard Australia as a developed country with advanced regulations for a market economy, and have expressed their willingness to learn from Australian practises if conditions allow. Although domestic regulators have so far resisted systematic change, they have gained a lot of knowledge on the operations of a market economy during the process of negotiation.

Similarly, because of the lack of authority of the Chinese Ministry of Finance over monetary policies, a structure uncommon in many other countries in the region, have constrained China's participation in regional financial cooperation, some scholars have started to call for institutional change. They argue for a more sophisticated policymaking institution and have recommended the government to learn from developed countries. The possibility for change certainly depends on the power relations between relevant government agencies as well as the force of the political leadership, but the institutions of other countries have become a potential source of learning.

China has recently started to review the structure of the state government, in particular the problems caused by fragmented regulation among ministries-lack of transparency, inconsistency of policies and the difficulty of policy coordination. The Chinese government is studying the government structures of developed countries and is experimenting with a 'big ministries system, ${ }^{17}$ Should some Chinese ministerial agencies be merged, for instance those in

${ }^{17}$ The $11^{\text {th }}$ National People's Congress in March 2008 endorsed the plan of structural reform of the Chinese government focusing on the formation of several 'big ministries' by merging several former 
charge of trade and industrial policies, some problems with coordination in the existing policymaking institution on regional economic cooperation would probably be solved.

\subsection{A new policy area}

The emergence of a new policy area provides policymakers with excuses to form or change institutions so that they can better obtain resources to deal with new challenges. FTAs as a new policy area to China in the past several years have facilitated the formation of a working mechanism for domestic policymaking. It takes the sequence of political endorsement of proposals, a feasibility study, joint working meetings organised by MOFCOM for coordination among relevant domestic actors, and the formation of a negotiation team. In particular, the joint working meetings have developed from an ad hoc arrangement voluntarily held by MOFTEC to gather information, to a necessary, regularised institution. At the joint working meetings, information is collected from multiple channels including ministries, business associations and scholars; human resources are drawn from various government agencies, some of whom participate directly in negotiations; and domestic opinions are exchanged, so that MOFCOM can have the legitimacy to represent domestic interests at FTA negotiations. In particular, because the AUCFTA is the first FTA China has negotiated with a major developed country, the Chinese government has invested unprecedented resources in policymaking - it designated the WTO Department of the MOFCOM as the lead agency because of its experience in international trade negotiations, and it gathered numerous government agencies to deal with problems in their fields. In a sense, a more democratised and informed policy making is being institutionalised by the joint working meetings mechanism.

Because of the important status of FTAs in current Chinese economic diplomacy, the Chinese government tries to make policymaking on FTAs more effective. In view of the difficulty of domestic coordination for the AUCFTA and the amount of work required by the number of FTAs China is engaged in, the government is considering establishing an 'FTA Leading Group' made of representatives of key government agencies which frequent the joint

ministerial agencies. The new ministries include the Ministries of Industry and Information Technology, Environment Protection, Human Resources and Social Security, Housing and Urban-Rural Construction, Transport and Transportation, as well as the National Energy Commission, which reflects the most pressing issues in China that demand more bureaucratic efficiency. 
working meetings, and a Premier-level leader to ease domestic tensions. Such an institution, if it is launched, like the Leading Group for WTO Affairs and other Leading Groups in the PRC's history to deal with important and pressing matters, would play a significant role in gathering resources and facilitate domestic coordination.

The emergence of a new policy area also provides opportunities for scholars to participate in policymaking because the government often lacks the capacity to conduct research on the implications of international cooperation on the domestic economy, either because the government's human resources are overstretched or because they lack expertise. Inviting scholars to conduct feasibility studies of FTAs or analysis on the suitability of regional financial cooperation proposals to China has become a common practise by parts of the Chinese government such as the Ministries of Commerce, Finance, and Agriculture. In some cases, the scholars borrow Western economic models, which make it possible for Western economic ideas to be institutionalised into Chinese policymaking.

\subsection{Change in the composition of key actors}

The change in the composition of key actors is another source of institutional change. As mentioned above, the policymaking institution led by MFA is more centralised than that led by MOFTEC/MOFCOM because of the political nature of MFA's portfolio and its high ranking among ministries. The policymaking institutions led by MOFCOM involve more actors and more complicated processes because it is concerned with practical economic gains, and its political status equals that of other industrial ministries and national economic commissions. Therefore, the change in the power of the foreign trade ministry vis-à-vis other government agencies is also an important factor in institutional change.

The change in leadership has a crucial impact on the policymaking institutions. Whereas institutions under Jiang-Zhu government were quite exclusive and operated in a top-down fashion to ensure swift, effective enforcement (such as that for the CAFTA on trade in goods, and the Leading Group on WTO Affairs), the institutions under the Hu-Wen government (such as those for the AUCFTA, and for the CAFTA on trade in services and investments) are more inclusive and emphasize consensus seeking to ensure that no radical policies are imposed on domestic sectors. 
In conclusion, this study has identified the sources of various policy preferences that the Chinese government has pursued in its regional economic cooperation. These originated from national and domestic interests as well as ideas held by policymakers. More importantly, it demonstrated that policymaking institutions have played a central role in deciding which of those policy preferences would be expressed by policy outcomes. In other words, preferences and institutions are both important, but institutions play the role of a filter. It calls for attention to three features of institutions - the degree of insulation of the central policymaker from domestic pressure, the degree of collective action within each domestic interest group, and the degree of fragmentation of policymaking power at the state level - to help understand foreign economic policymaking. It varies across issue areas and the trend is not linear, but with a decreasing degree of insulation, increasing degree of fragmentation and increasing degree of collective action within some domestic groups, China seems not so different from democratic countries in terms of the constraints that domestic politics can place on the state's autonomy in foreign economic policymaking. Moreover, it finds that although institutions do resist change, institutional development happens under institutional learning, the emergence of a new policy area or the change in the composition of key actors.

This study hopes to contribute to the studies of China's economic diplomacy, regionalism, and policymaking in general with the empirical data of three in-depth case studies on China's policymaking towards regional economic cooperation. It shows that an institutional analysis of policymaking holds potential for integrating material, ideational and relational factors in explaining foreign economic policy, and it underlines the importance of domestic factors for understanding a state's international behaviour. 


\section{Appendix: List of Affiliation of Interviewees and Number of Interviewees}

Affiliation

Number

Ministry of Commerce

Ministry of Foreign Affairs

Ministry of Finance

People's Bank of China

Ministry of Agriculture 3

Ministry of Information Industry 1

National Development and Reform Commission 4

China Banking Regulatory Commission 1

Chinese Embassy in Canberra 2

Australian Embassy in Beijing 1

China-ASEAN Business Council, Beijing 1

China Council for the Promotion of International Trade, Beijing 1

China Iron and Steel Association, Beijing 1

Chamber of Commerce of Import and Export of Food Stuffs, Native 1

Produce and Animal By-Products, Beijing

China-Australia Chamber of Commerce, Beijing 1

Beijing University 8

Nankai University, Tianjin 4

PECC, Beijing 1

Chinese Academy of Social Sciences 9

Chinese Academy of Sciences 1

China Institute of Contemporary International Relations, Beijing 4

Institute of Foreign Trade and Economic Cooperation, Beijing 2

China Agriculture University, Beijing 2

Renmin University, Beijing 2

University of Foreign Affairs, Beijing 1

Yunnan University, Kunming 1

Yunnan Provincial Bureau of Agriculture 1

Yunnan Provincial Bureau of Commerce 1

Yunnan Academy of Social Sciences 1

Guangxi Provincial Bureau of Commerce 1

Guangxi Academy of Social Sciences, Nanning 1

Institute of Southeast Asian Studies, Singapore 1

Australian Services Roundtable, Canberra 1

Australian Attorney-General's Department 1

Australian Department of Foreign Affairs and Trade 2 


\section{Bibliography}

Acemoglu, Daron and James Robinson. The Economic Origins of Dictatorship and Democracy: Economic and Political Origins. New York: Cambridge University Press, 2005.

Alt, James E., and Michael J. Gilligan Jeffry Frieden, Dani Rodrik, and Ronald Rogowski. "The Political Economy of International Trade: Enduring Puzzles and an Agenda for Inquiry." Comparative Political Studies 29, no. 6 (1996): 689-717.

Amyx, Jennifer. "Regional Financial Cooperation in East Asia since the Asian Financial Crisis." In Crisis as Catalyst: Asia's Dynamic Political Economy, edited by Andrew Macintyre, T.J. Pempel and John Ravenhill, 117-39. Ithaca: Cornell University Press, 2008. "What Motivates Regional Financial Cooperation in East Asia Today?" Asia-Pacific Issues Paper, East-West Center, no. 76 (March 2005).

. "Moving Beyond Bilateralism? Japan and the Asian Monetary Fund." Pacific Economic Paper, Australia-Japan Research Centre, Australian National University, no. 331 (2002).

Armitage, Catherine. "Expert Dampens China FT A Hopes." The Australian, 22 June 2005. "Changes Likely to Laws for Investors." The Australian, 20 April 2005

Asami, Tadahiro. Chiang Mai Initiative as the Foundation of Financial Stability in East Asia, ASEAN+3 Research Group Studies 2004-2005, 1 March 2005, http://www.aseansec.org/17905.pdf.

ASEAN+3 Study Group, Report on Trade, Investment and Financial Integration in East Asia 2004-2005, http://www.aseansec.org/17880.htm.

Aslund, Anders, Peter Boone and Simon Johnson. "How to Stabilize: Lessons from PostCommunist Countries." Brookings Papers on Economic Activity 1 (1996): 217-311.

Athukorala, Premachandra. "Product Fragmentation and Trade Patterns in East Asia." Asian Economic Papers 4, no. 3 (October 2005): 1-27.

Attwood, James. "Australian Miners Place Big Hopes on China FTA." Dow Jones Newswires, 19 April 2005

Australian Chamber of Commerce and Industry, "Riding the Chinese Dragon: Opportunities and Challenges for Australia and the World." online at http://www.acci.asn.au/IssuesPapersMain.htm., August 2005.

Australian Senate Standing Committee on Foreign Affairs, Defence and Trade. Proof Committee Hansard Estimates, 29 May 2007, http://www.aph.gov.au/hansard/senate/commttee/S10267.pdf.

Baldwin, David A. Economic Statecraft. Princeton, N.J.: Princeton University Press, 1985.

Baldwin, Richard E., and Frederic Robert-Nicoud. "Entry and Asymmetric Lobbying: Why Governments Pick Losers." National Bureau of Economic Research Working Paper, no. 8756 (2002).

Bao, Shuming, Shuanglin Lin, and Changwen Zhao, eds. The Chinese Economy after WTO Accession. Aldershot, Hants, England; Burlington, VT: Ashgate, 2006.

Barnett, A. Doak. Cadres, Bureaucracy, and Political Power in Communist China. New York: Columbia University Press, 1967.

Bernardino, Natividad Y. "The ASEAN-China Free Trade Area: Issues and Prospects." Asia Pacific Network on Food Sovereignty Regional Workshop Papers (6-9 November 2004).

Bhagwati, Jagdish N. "Regionalism and Multilateralism: An Overview." In New Dimensions in Regional Integration, edited by Jaime de Melo and Arvind Panagariya, 22-51. New York: Cambridge University Press, 1993.

Bhagwati, Jagdish N., and Anne O. Krueger. The Dangerous Drift to Preferential Trade Agreements, AEI Special Studies in Policy Reform. Washington, D.C.: AEI Press, 1995.

Bhagwati, Jagdish N., Pravin Krishna, and Arvind Panagariya. Trading Blocs: Alternative Approaches to Analyzing Preferential Trade Agreements. Cambridge, Mass.: MIT Press, 1999.

Blyth, Mark M. "Any More Bright Ideas? The Ideational Turn of Comparative Political Economy." Comparative Politics 29, no. 2 (January, 1997): 229-50.

Breslin, Shaun. China and the Global Political Economy. New York, N.Y.: Palgrave Macmillan, 2007. 
. "Power and Production: Rethinking China's Global Economic Role." Review of International Studies 31(2005): 735-53.

"Reforming China's Embedded Socialist Compromise: China and the WTO." Global Change, Peace and Security 15, no. 3 (October 2003): 213-29.

"Paradigm Shifts and Time-lags? The Politics of Financial Reform in the People's Republic of China." Asian Business \& Management 2 (2003): 143-66.

"The Politics of Chinese Trade and the Asian Financial Crises: Questioning the Wisdom of Export-led Growth." Third World Quarterly 20, no. 6 (1999): 1179-99.

Breslin, Shaun, and Richard Higgott. "Studying Regions: Learning from the Old, Constructing the New." New Political Economy 5, no. 3 (2000): 333-52.

Brødsgaard, Kjeld Erik and Zheng Yongnian eds. The Chinese Communist Party in Reform.

Hong Kong: Hong Kong Chinese University Press, 2007.

Brooker, Paul. Non-Democratic Regimes: Theory, Government and Politics. New York: Palgrave Macmillan, 2000.

Brown, Owen. "Long March for Australia, China FTA." Down Jones Newswires, 20 April 2005

Callick, Rowan. "A Mutual Attraction." Australian Financial Review (23 August 2004).

Cao, Xin. "Yazhou Jinrong Weiji dui Zhongguo Jingji de Yingxiang jiqi Duice [Impacts of the Asian Financial Crisis on China's Economy and Its Countermeasures]." Lilun Shiye [Theoretical Horizon], no. 51998).

Capie, David. "Rival Regions? East Asian Regionalism and Its Challenge to the Asia-Pacific." In The Asia-Pacific: A Region in Transition edited by Jim Rolfe, 149-65. Honolulu: Asia-Pacific Center for Security Studies, 2004.

Capling, Ann. All the Way with the USA: Australia, the United States and Free Trade. Sydney: University of New South Wales Press, 2005.

Australia and the Global Trade System: From Havana to Seattle. Cambridge; New York: Cambridge University Press, 2001.

CASS. "CEPA: Yuanqi, Yiyi Ji Yingxiang [CEPA: Origin, Nature and Implications]." The Pursuit of Economic Trends 48, no. 388 (8 July 2003).

Chan, Gerald. "China and the WTO: Theory and Practice of Compliance." International Relations of the Asia-Pacific 4 (2004): 47-72.

Chase, Kerry A. "Economic Interests and Regional Trading Arrangements: The Case of NAFTA." International Organization 57 (Winter 2003): 137-74.

Chen, Feng. "The Unfinished Battle in China: The Leftist Criticism of the Reform and the Third Thought Emancipation." The China Quarterly no. 158 (June 1999): 447-67.

Chen, Fengjun. "Jinrong Weiji hou Yatai Geju de Bianhua [Changes in the Asia Pacific Structure after the Financial Crisis]." Guoji Zhengzhi Yanjiu [International Politics Studies], no. 2 (1999): 24-32.

Chen, Hong. "Peiyu Dongya Zhaiquan Shichang: Xianzhuang, Zhang'ai yu Qianjing [Developing East Asian Bond Market: Status, Obstacles and Prospects]." Shijie Jingji [World Economy], no. 2 (2007): 74-80.

Chen, Qiaozhi, ed. Dongya Quyu Jingji Hezuo Yanjiu [Studies of East Asian Regional Economic Cooperation]. Beijing: China Social Sciences Press, 2002.

Chen, Rukai. "The Study of Free Trade between China and Australia on Sugar." The AustraliaChina FTA Agricultural Conference, Xi'an, 27 September 2006.

Chen, Xiangyang. Zhongguo Mu Lin Waijiao: Sixiang, Shijian, Qianzhan [China's GoodNeighbour Diplomacy: Thought, Practice and Prospect]. Beijing: Current Affairs Press, 2004.

Chen, Zhonghua. "Speech at the Australia-China Free Trade Conference." Shenzhen, 28-29 June 2006.

Cheung, Peter T.Y., Jae Ho Chung, and Zhimin Lin, eds. Provincial Strategies of Economic Reform in Post-Mao China. Armonk and London: M. E. Sharpe, 1998.

Cheung, Peter T.Y., and James T.H. Tang. "The External Relations of China's Provinces." In The Making of Chinese Foreign and Security Policy in the Era of Reform, 1978-2000, edited by David M. Lampton, 91-120. Stanford: Stanford University Press, 2001.

Chirathivat, Suthiphand. "ASEAN-China Free Trade Area: Background, Implications and Future Development." Journal of Asian Economics 132002): 671-86. 
Crawford, Jo-Ann, and Sam Laird. "Regional Trade Agreements and the WTO." North American Journal of Economics and Finance 12, no. 2 (July 2001): 193-211.

Deng, Xiuxin. "China's Fruit Production and Bilateral Fruit Trade between China and Australia." The Australia-China FTA Agricultural Conference, Xi'an, 27 September 2006.

Deng, Yong and Fei-Ling Wang, eds. China Rising: Power and Motivation in Chinese Foreign Policy. Lanham, MD.: Rowman \& Littlefield, 2005.

Destler, I. M. American Trade Politics. 3rd ed. Washington D.C.: Institute for International Economics, 1995.

Diao, Chunhe. "Strengthening Australia-China Cooperation in Engineering \& Contracting and Promote the Common Development of Services Trade." the Australia-China FTA Services Conference, Beijing, 24 April 2006.

Dickson, Bruce J. Red Capitalists in China: The Party, Private Entrepreneurs, and Prospects for Political Change, Cambridge Modern China Series. New York: Cambridge University Press, 2003.

Dieter, Heribert, and Richard Higgot. "Exploring Alternative Theories of Economic Regionalism: From Trade to Finance in Asian Co-operation?" Review of International Political Economy 10, no. 3 (August 2003): 430-54.

Dobell, Graeme. "China Trade Negotiations 'Tortuous' Says Truss." ABC News, 16 June 2007 http://www.abc.net.au/news/stories/2007/06/16/1953209.htm.

Dobson, Wendy. "Greater Integration in East Asia: Regional Institutions and the International Economic System." The World Economy 24, no. 8 (2002): 995-1018.

Doyle, Michael. "Liberalism and World Politics." American Political Science Review 80 (December 1986): 1151-69.

Drake-Brockman, Jane. "Chinese Approaches to Negotiation: Implications of Contemporary Practices for the Future." The China's Future Diplomacy Research and Public Symposium, Canberra, 3-4 July 2006.

Drezner, Daniel. "Ideas, Bureaucratic Politics, and the Crafting of Foreign Policy." American Journal of Political Science 44 (October 2000): 733-49.

Du, Min. "Analysis and Prospects of China's Cotton Market after the Entry to WTO." The Australia-China FTA Agricultural Conference, Xi'an, 27 September 2006.

Eichengreen, Barry. "Real and Pseudo Preconditions for an Asian Monetary Union." Paper presented at the paper presented at the Asian Development Bank High-Level Conference on Asia's Economic Cooperation and Integration, Manila, July 2004. .."International Monetary Arrangements: Is There a Monetary Union in Asia's Future?" Brookings Review 15 (Spring 1997).

Ernst, Dieter. "Global Production Networks in East Asia's Electronics Industry and Upgrading: Perspectives in Malaysia." East-West Center (Honolulu) Working Papers, Economics Series 44 (May 2002).

Fan, Gang. "Quanqiuhua zhong de Bupingdeng Wenti: Yazhou Jinrong Weiji de Jiaoxun ji Zhengce Hanyi [Inequality in Globalization: Lessons from Asian Financial Crisis and Policy Implications]." Guoji Jingji Pinglun [International Economic Review], no. 3 (1999): 41-44.

Fearon, James."Domestic Audiences and the Escalation of International Disputes." American Political Science Review 88, no. 3 (1994): 577-92.

Feng, Hui. The Politics of China's Accession to the World Trade Organisation: The Dragon Goes Global. London and New York: Routledge, 2006.

Fewsmith, Joseph. "China and the WTO: Politics Behind the Agreement." NBR Analysis 10, no. 5 (December 1999): 23-39.

Freund, Caroline. "Reciprocity in Free Trade Agreements." World Bank Working Paper, no. 3061 (2003).

Frieden, Jeffry. "Sectoral Conflict and U.S. Foreign Economic Policy, 1914-1940." International Organization 42 (Winter 1988): 59-90.

Frye, Timothy, and Edward D. Mansfield. "Fragmenting Protection: The Political Economy of Trade Policy in the Post-Communist World." British Journal of Political Science 33 (October 2003): 635-57. 
Fung, Hung-Gay, Changhong Pei, and Kevin H. Zhang., eds. China and the Challenge of Economic Globalization: The Impact of WTO Membership. Armonk, New York: M.E. Sharpe, 2006.

Gao, Haihong. "Monetary Cooperation in East Asia: How Far Can East Asian Countries Go?" Paper presented at the East Asian Monetary Cooperation and China's Perspective Conference, Beijing, 24 August 2007.

"Cong Qingmai Changyi dao Yazhou Zhaiquan Jijin [From Chiang Mai Initiative to Asian Bond Fund]." Guoji Jingji Pinglun [International Economic Review], no. 3 (2004).

Garnaut, John. "Give and Take as China Inches towards Trade Talks." Sydney Morning Herald, 20 April 2005

Garnaut, Ross and Dominic Wilson, "The East Asian Financial Crisis: Regional and Global Responses." In Private Capital Flows in the Age of Globalization edited by Uri Dadush, Dipak Dasgupta and Marc Uzan, 63-80. Edward Elgar, 2000.

Garrett, Geoffrey and Peter Lange. "Internationalization, Institutions, and Political Change.” In Internationalization and Domestic Politics, edited by Robert O. Keohane and Helen V. Milner. New York: Cambridge University Press, 1996.

Gaulier, Guillaume, Francoise Lemoine, and Deniz Unal-Kesenci. "China's Integration in Asian Production Networks and Its Implications." Paper presented at the Conference on Resolving New Global and Regional Imbalances in an Era of Asian Integration, Tokyo: Research Institute of Economy, Trade, and Industry [RIETI], 2004.

Gilligan, Michael J. Empowering Exporters: Reciprocity, Delegation, and Collective Action in American Trade Policy, Michigan Studies in International Political Economy. Ann Arbor: The University of Michigan Press, 1997.

Gittins, Ross. "FTA: Bad Politics Drives Out Good Economics." Sydney Morning Herald, 9 August 2004

Goldman, Merle. "The Emergence of Politically Independent Intellectuals." In The Paradox of China's Post-Mao Reforms edited by Merle Goldman and Roderick MacFarquhar, 283307. Cambridge, Mass.: Harvard University Press, 1999.

Goldstein, Judith. "The Impact of Ideas on Trade Policy: The Origins of U.S. Agricultural and Manufacturing Policies." International Organization 43, no. 1 (Winter 1989): 31-71.

Goldstein, Judith, Robert O. Keohane, and Social Science Research Council (U.S.). Committee on Foreign Policy Studies. Ideas and Foreign Policy: Beliefs, Institutions, and Political Change, Cornell Studies in Political Economy. Ithaca: Cornell University Press, 1993.

Goldstein, Judith, and Lisa L. Martin. "Legalization, Trade Liberalization, and Domestic Politics: A Cautionary Note." International Organization 54 (Summer 2000): 219-48.

Granovetter, Mark and Richard Swedberg, eds. The Sociology of Economic Life. Boulder: Westview Press, 1992.

Grattan, Michelle. "China Free Trade: Icing on the Cake or Sugar Coating?" The Age, 20 April 2005.

Haggard, Stephan. Pathways from the Periphery: The Politics of Growth in Newly Industrializing Countries. Ithaca, NY: Cornell University Press, 1990.

Haggard, Stephan and Steven B. Webb. "What Do We Know about the Political Economy of Economic Policy Reform?" World Bank Research Observer 8 (1993): 143-67.

Haggard, Stephan, Steven Benjamin Webb, and World Bank. Voting for Reform: Democracy, Political Liberalization, and Economic Adjustment. New York: Published for the World Bank, Oxford University Press, 1994.

Hall, Peter A. Governing the Economy: The Politics of State Intervention in Britain and France. New York: Oxford University Press, 1986.

"The Movement from Keynesianism to Monetarism: Institutional Analysis and British Economic Policy in the 1970s." In Structuring Politics: Historical Institutionalism in Comparative Analysis, edited by Sven Steinmo, Kathleen Ann Thelen and Frank Longstreth, 91-113. Cambridge [England]; New York: Cambridge University Press, 1992.

Hamrin, Carol Lee, and Suisheng Zhao, eds. Decision-Making in Deng's China: Perspectives from Insiders. Armonk; London: East Gate Book, 1995. 
Harding, Harry. China's Second Revolution: Reform after Mao. Washington D.C.: Brookings Institution, 1987.

Harris, Stuart. "The Merger of the Foreign Affairs and Trade Departments Revisited." Australian Journal of International Affairs 56, no. 2 (2002): 223-35.

"Globalisation and China's Diplomacy: Structure and Process." In Working Paper. Canberra: Department of International Relations, Research School of Pacific and Asian Studies, Australian National University, 2002.

"Asian Multilateral Institutions and Their Response to the Asian Economic Crisis: The Regional and Global Implications. " Pacific Review 13, 3 (2000): 495-516.

."China's Role in WTO and APEC." In China Rising: Nationalism and Interdependence, edited by David Goodman and Gerald Segal, 134-55. London: Routledge, 1997.

Hausken, Kjell, Thomas Plumper, and Gerald Schneider. "The Trilemma of the Protectionist Autocrat: An Assessment of the Political Determinants of Foreign Economic Liberalization." Stavanger, Norway: School of Economics, University of Stavanger, 2002.

He, Bingmeng, Rongcang Liu, and Shucheng Liu. Asian Financial Crisis: Latest Analysis and Measures [Yazhou Jinrong Weiji: Zuixin Fenxi yu Duice]. Beijing: Social Sciences Literature Press, 1998.

He, Fan. "Bing bu ziyou de ziyou xieding [FTAs Not Free]." The Economic Observer, 18 December 2005, http://finance.sina.com.cn/j/20051218/18092207715.shtml. "Weiji zhihou de Yazou Huobi Hezuo [Asian Monetary Cooperation after Crisis]." Guoji Jingii Pinglun [International Economic Review], no. 1-2 (2001): 23-26.

He, Fan, Bin Zhang, and Ming Zhang. After the CMI: The Future of Asian Monetary Cooperation and China's Role, ASEAN+3 Research Group Studies 2004-2005. Beijing: China Academy of Social Sciences, 2005.

He, Shengda, Xuehong Wang, and Zhankui Gong, eds. Zhongguo-Dongmeng Ziyou Maoyiqu Jianshe Yu Yunnan Mianxiang Dongnanya Kaifang [The Construction of the ASEANChina Free Trade Area and Yunnan's Opening to Southeast Asia]. Kunming: Yunnan People's Press, 2003.

Heath, Ian. "Intellectual Property and the Free Trade Agreement Process." the Australia-China Free Trade Conference, Shenzhen, 28-29 June 2006.

Hellman, Joel S. "Winners Take All: The Politics of Partial Reform in Postcommunist Transitions." World Politics 50, no. 2 (1998): 203-34.

Henisz, Witold J., and Edward D. Mansfield. "Votes and Vetoes: The Political Determinants of Commercial Openness." International Studies Quarterly 50 (2006): 189-211.

Henning, C. Randall. East Asian Financial Cooperation, Policy Analyses in International Economics. Washington DC: Institute for International Economics, 2002.

. East Asian Financial Cooperation. Vol. 68, Policy Analyses in International Economics. Washington D.C.: Institute for International Economics, 2002.

Herrmann, Richard K., Philip E. Tetlock, and Matthew N. Diascro. "How Americans Think About Trade: Reconciling Conflicts among Money, Power, and Principles." International Studies Quarterly 45, no. 2 (2001): 191-218.

Hiscox, Michael J. "The Domestic Sources of Foreign Economic Policies." In Global Political Economy, edited by John Ravenhill, 50-83. Oxford: Oxford University Press, 2005. . "Class Versus Industry Cleavages: Inter-Industry Factor Mobility and the Politics of Trade." International Organization 55 (Winter 2001): 1-46.

Holbig, Heike, and Robert Ash, eds. China's Accession to the World Trade Organization: National and International Perspectives. New York: RoutledgeCurzon, 2002.

Hu, Xiao. "Agreements Pave Way for Chinese-Australian FTA." China Daily (North American ed.), 19 April 2005

Huang, Kwei-Bo. "The China-ASEAN Free Trade Area: Background, Framework and Political Implications." In Peace Forum. Taiwan Research Institute, 2002.

Huang, Rengang. "How Has Accession to the WTO Changed Trade Policy Making in China?" The Workshop on Trade Policymaking in Developing Countries, the London School of Economics and Political Science, 25 May 2005. 
Huang, Yasheng. "Is China Playing by the Rules? Free Trade, Fair Trade and WTO Compliance." Statement at the Congressional-Executive Commission on China, September 24, 2003.

Hughes, Christopher R. "Nationalism and Multilateralism in Chinese Foreign Policy: Implications for Southeast Asia." The Pacific Review 18, no. 1 (March 2005): 119-35.

Ianchovichina, Elena, Sethaput Suthiwart-Narueput, and Min Zhao. "Regional Impact of China's WTO Accession." In East Asia Integrates: A Trade Policy Agenda for Shared Growth, edited by Kathie L. Krumm and Homi J. Kharas, 57-78. Washington, D.C: World Bank, 2004.

Ianchovichina, Elena, and Terrie Louise Walmsley. "The Impact of China's WTO Accession on East Asia." World Bank Poverty Reduction and Economic Management Network Economic Policy Division (Washington, D.C.), Policy Research Working Paper, no. 3109 (August 2003).

IIMA. Report Summary of Studies on Toward a Regional Financial Architecture for East Asia, ASEAN+3 Finance Ministers Meeting, 29 March 2004, http://www.mof.go.jp/jouhou/kokkin/ASEAN+3research-1-1.pdf.

Ikenberry, G. John. "Conclusion: An Institutional Approach to American Foreign Economic Policy." International Organization 42, no. 1 (Winter 1988): 219-43.

Jacobson, Harold K., and Michel Oksenberg. China's Participation in the IMF, the World Bank, and GATT: Toward a Global Economic Order. Ann Arbor: The University of Michigan Press, 1990.

Jiang, Ruiping. "Dangqian Dongya Jinrong Hezuo Xingshi Pinggu ji Jianyi [A Review of and Suggestions for Current East Asian Financial Cooperation]." Waijiao Pinglun [Review of Diplomacy], no. 3 (2007): 28-29.

Jiao, Jinpu. "The Opening Up of China's Finance Industry: Ongoing Process and Current Status." The Australia-China FTA Services Conference, Beijing, 24 April 2006.

Katzenstein, Peter J. "International Relations and Domestic Structures: Foreign Economic Policies of Advanced Industrial States." International Organization 30, no. 1 (Winter 1976): 1-45.

Kawai, Masahiro "East Asian Economic Regionalism: Progress and Challenges." Journal of Asian Economics 16, no.1 (2005): 29-55

Kennedy, Scott. The Business of Lobbying in China. Cambridge, Mass.: Harvard University Press, 2005.

Kent, Ann E. Beyond Compliance: China, International organizations, and Global Security, Studies in Asian security. Stanford, Calif:: Stanford University Press, 2007. "China's International Socialization." Global Governance 8, no. 3 (Jul-Sep 2002): 34364.

"China, International Organizations and Regimes: The ILO as a Case Study in Organizational Learning." Pacific Affairs 70, no. 4 (Winter 1997/1998): 517-32.

Koch, Jessica. "Economic Development and Ethnic Separatism in Western China: A New Model of Peripheral Nationalism." Murdoch University Asia Research Centre Working Paper no. 134 (August 2006).

Koelble, Thomas A. "The New Institutionalism in Political Science and Sociology." Comparative Politics 27, no. 2 (January 1995): 231-43.

Kohler, Alan. "FTAs Protectionism in Disguise: Garnaut." Inside Business, ABC Australia, 24 April 2005

Krasner, Stephen D. "Approaches to the State: Alternative Conceptions and Historical Dynamics." Comparative Politics 16, no. 2 (January 1984): 223-46.

Krever, Tor. "The US-Australia Free Trade Agreement: The Interface between Partisan Politics and National Objectives." Australian Journal of Political Science 41, no. 1 (March 2006): 51-69.

Krugman, Paul R. "Import Protection as Export Promotion: International Competition in the Presence of Oligopoly and Economies of Scale." In Imperfect Competition and International Trade, edited by Gene M. Grossman, 75-86. Cambridge, Mass.: MIT Press, 1993.

Kuik, Cheng-Chwee. "Multilateralism in China's ASEAN Policy: Its Evolution, Characteristics, and Aspiration." Contemporary Southeast Asia 27, no. 1 (2005): 102-22. 
Kunkel, John. "Australian Trade Policy in an Age of Globalization." Australian Journal of International Affairs 56, no. 2 (2002): 237-51.

Kwak, Sung Yeung. "An Optimum Currency Area in East Asia: Feasibility, Coordination, and Leadership Role " Journal of Asian Economics 15, no. 1 (February 2004): 153-69.

Lake, David. "International Economic Structures and American Foreign Economic Policy, 1887-1934." World Politics 35 (July 1983): 517-43.

Lampton, David M., ed. The Making of Chinese Foreign and Security Policy in the Era of Reform, 1978-2000. Stanford: Stanford University Press, 2001.

Lardy, Nicholas R. "China's Domestic Economy: Continued Growth or Collapse?" In China, The Balance Sheet: What the World Needs to Know Now About the Emerging Superpower, edited by C. Fred Bergsten, Bates Gill, Nicholas R. Lardy and Derek J. Mitchell. Washington D.C.: Center for Strategic and International Studies and the Peterson Institute for International Economics, 2006. Integrating China into the Global Economy. Washington, D.C.: Brookings Institution Press, 2002.

Lee, Yong Wook. "Japan and the Asian Monetary Fund: An Identity-Intention Approach." International Studies Quarterly 50 (2006): 339-66.

Leifer, Michael. "The ASEAN Peace Process: A Category Mistake." The Pacific Review 12, no. 1 (1999): 25-38.

Li, Chenggui. "Zhongguo Dami Zhengce Fenxi [an Analysis of Rice Policy in China]." China Agricultural Economics, no. 9 (2002).

Li, Hong. "Analysis and Prediction on Sino-ASEAN Trade 2005-2006." Around Southeast Asia, no. 3 (2006): 1-3.

Li, Pinghai. "Yazhou Quyu Jinrong Hezuo zhong de Riben yu Zhongguo [Japan and China in Asian Regional Financial Cooperation]." Riben Xuekan [The Japan Journal], no. 22006): 85-96.

Liao, Xiaoqi. "Speech at the Australia-China Free Trade Conference." Shenzhen, 28-29 June 2006.

Lieberthal, Kenneth G., and David M. Lampton, eds. Bureaucracy, Politics, and Decision Making in Post-Mao China. Berkeley: University of California Press, 1992.

Lieberman, Robert C. "Ideas, Institutions and Political Order: Explaining Political Change." American Political Science Review 96, no. 4 (December 2002): 697-712.

Lin, Le, and Zheng Gong. "Guanyu Yazhou Huobi Jijin Youxiaoxing de Fenxi [An Analysis of the Effectiveness of the AMF]." Guoji Jinrong Yanjiu [International Financial Studies], no. 82001): 26-29.

Lipscy, Phillip Y. "Japan's Asian Monetary Fund Proposal." Stanford Journal of East Asian Affairs 3, no. 1 (Spring 2003): 93-104.

Liu, Zhongqun, Shuquan Huang, and Lin Wang. "A Research Summary on the Structure of China's Agricultural Exports to ASEAN." Around Southeast Asia, no. 4 (2006): 35-39.

Lockhart, Nicholas, and Andrew D. Mitchell. "Regional Trade Agreements under GATT 1994: An Exception and Its Limits." In Challenges and Prospects for the WTO, edited by Andrew D. Mitchell, 217-52. London: Cameron May, 2005.

Lohmann, Susanne, and Sharyn O'Halloran. "Divided Government and Us Trade Policy: Theory and Evidence." International Organization 48, no. 4 (Autumn 1994): 595-632.

Long, Yongtu. September 1996. Statement by Mr. Long Yongtu, Assistant Minister of Foreign Trade and Economic Cooperation, People's Republic of China at the Ministerial Conference of WTO in Singapore.

http://www.wto.org/english/thewto_e/minist_e/min96_e/st117.htm.

Lu, Ning. The Dynamics of Foreign-Policy Decisionmaking in China. 2nd ed. Boulder, Colo.: Westview Press, 2000.

Lv, Xuan, and Wei En. "Yazhou Huobi Jijin: Huigun he Zhanwang [Asian Monetary Fund: Retrospect and Prospect]." Zhongguo Waihui Guanli [China Foreign Exchange Management], no. 102003): 18-19.

Mai, Yinhua, Philip Adams, Mingtai Fan, Ronglin Li, and Zhaoyang Zheng. "Modelling the Potential Benefits of an Australia-China Free Trade Agreement (An Independent report prepared for the Australia-China FTA Feasibility Study)." 2 March 2005,

http://www.dfat.gov.au/geo/china/fta/. 
Mansfield, Edward, and Helen V. Milner. "The New Wave of Regionalism." International Organization 53, no. 3 (1999): 589-27.

Mansfield, Edward D., Helen V. Milner, and B. Peter Rosendorff. "Why Democracies Cooperate More: Electoral Control and International Trade Agreements." International Organization 56, no. 3 (Summer 2002): 477-513.

. "Free to Trade: Democracies, Autocracies, and International Trade." American Political Science Review 94, no. 2 (June 2000).

Mansfield, Edward D., and Marc L. Busch. "The Political Economy of Nontariff Barriers: A Cross-National Analysis." International Organization 49, no. 4 (Autumn 1995): 723-49

March, James G. and Johan P. Olsen. Rediscovering Institutions. New York: Free Press, 1989.

Martin, Lisa. Democratic Commitments: Legislatures and International Cooperation. Princeton: Princeton University Press, 2000.

McMillan, John, Barry Naughton. Reforming Asian Socialism: The Growth of Market Institutions. Ann Arbor: University of Michigan Press, 1996.

Medeiros, Evan S., and M. Taylor Fravel. "China's New Diplomacy." Foreign Affairs 82, no. 6 (Nov/Dec 2003): 22-35.

Mertha, Andrew, and Robert Pahre. "Patently Misleading: Partial Implementation and Bargaining Leverage in Sino-American Negotiations on Intellectual Property Rights." International Organization 59 (Summer 2005): 695-729.

MFA, China. "Premier Wen Jiabao Holds Talks with Australian Prime Minister John Howard." 28 June 2006 http://www.fmprc.gov.cn/eng/zxxx/t260999.htm.

Milner, Helen V. "Why the Move to Free Trade: Democracy and Trade Policy in the Developing Countries." International Organization 59 (Winter 2005): 107-43. . "The Political Economy of International Trade." Annual Review of Political Science 2 (1999): 91-114.

Milner, Helen V. , B. Peter Rosendorff, and Edward D. Mansfield. "International Trade and Domestic Politics: The Domestic Sources of International Trade Agreements and Institutions." In The Impact of International Law on International Cooperation: Theoretical Perspectives, edited by Eyal Benvenisti and Moshe Hirsch, 216-43. New York: Cambridge University Press, 2004.

Mishra, Pankaj. "China's New Leftist.” The New York Times, 15 October 2006.

Montinola, Gabriella, Yingyi Qian, and Barry R. Weingast. "Federalism, Chinese Style: The Political Basis for Economic Success." World Politics 48, no. 1 (1996): 50-81.

Moneyhon, Mathew D. "Taming China's "Wild West": Ethnic Conflict in Xinjiang." Peace, Conflict, and Development: An Interdisciplinary Journal 5, no. 5 (2004): 2-23.

Mundell, Robert. "Prospects for an Asian Currency Area." Journal of Asian Economies 14, no. 1 (February 2003): 1-10.

."Currency Areas, Exchange Rate Systems and International Monetary Reform." Journal of Applied Economics 3 (November 2000): 217-56.

"A Theory of Optimum Currency Areas." The American Economic Review 51(1961): 657-65.

Murphy, Katharine. "FTA with China Won't Cut into Clothes Market." The Australian, 25 May 2005

Narintarakul, Kingkorn. "Thai-China Free Trade Agreement for Whose Benefit?" Asia Pacific Network on Food Sovereignty Regional Workshop Papers (6-9 November 2004).

Naughton, Barry. "China's Transition in Economic Perspective." In The Paradox of China's Post-Mao Reforms, edited by Merle Goldman and Roderick MacFarquhar, 30-44. Cambridge, Mass.: Harvard University Press, 1999.

Nelson, Joan M. "How Market Reforms and Democratic Consolidation Affect Each Other." In Intricate Links: Democratization and Market Reforms in Latin America and Eastern Europe, edited by Joan M. Nelson, 1-36. New Brunswick, NJ: Transaction Publishers, 1994.

Nevitt, Christopher E. "Private Business Associations in China: Evidence of Civil Society or Local State Power." China Journal 36 (July 1996): 25-45.

North, Douglass C. Institutions, Institutional Change, and Economic Performance. Cambridge: Cambridge University Press, 1990. 
O'Donnell, Guillermo. Modernization and Bureaucratic-Authoritarianism: Studies in South American Politics. Berkeley: Institute of International Studies, University of California, 1973.

Olson, Mancur. The Logic of Collective Action: Public Goods and the Theory of Groups, Harvard Economic Studies, V. 124. Cambridge, Mass.,: Harvard University Press, 1965

Oxfam. "South-South Tensions: The Case of the ASEAN-China Free Trade Area." Paper presented at the Grantmakers Without Borders Conference, Miami, October 2004.

Park, Yung Chul, and Yunjong Wang. "The Chiang Mai Initiative and Beyond." The World Economy 28, no. 1 (January 2005): 91-101.

Pascha, Werner. "The Role of Regional Financial Arrangements and Monetary Integration in East Asia and Europe in Relations with the United States." The Pacific Review 20, no. 3 (September 2007): 423-66.

Pearson, Margaret M. "China's WTO Implementation in Comparative Perspective: Lessons from the Literatures in Trade Policy and Regulation." The Review of International Affairs 3, no. 4 (Summer 2004): 567-83.

Is China Playing by the Rules? Free Trade, Fair Trade and WTO Compliance, Statement at the Congressional-Executive Commission on China, September 24, 2003. "The Case of China's Accession to GATT/WTO." In The Making of Chinese Foreign and Security Policy in the Era of Reform, 1978-2000, edited by David M. Lampton, 337-70. Stanford: Stanford University Press, 2001.

Perkins, Dwight Heald. "China's Economic Policy and Performance." In Cambridge History of China, edited by Roderick MacFarquhar and John K. Fairbank, 488-90. Cambridge: Cambridge University Press, 2001.

Powell, Walter W. and Paul J. Di Maggio, eds. The New Institutionalism in Organizational Analysis. Chicago: University of Chicago Press, 1991.

Putnam, Robert D. "Diplomacy and Domestic Politics: The Logic of Two-Level Games." International Organization 42, no. 3 (Summer 1988): 427-60.

Qin, Jize. "New Zealand Set to Hit Another 1st with China." China Daily (North American ed.), 11 June 2005.

Qu, Baoxiang. "The Changes in Production and Consumption of Wheat and Barley in China and the Development of the Trade between China and Australia." The Australia-China FTA Agricultural Conference, Xi'an, 27 September 2006.

Rapkin, David P. "The United States, Japan, and the Power to Block: The APEC and AMF Cases." The Pacific Review 14, no. 3 (2001): 373-410.

Ravenhill, John. "Is China an Economic Threat to Southeast Asia?" Asian Survey 46, no. 5 (September/October 2006): 653-74.

"Regionalism." In Global Political Economy, edited by John Ravenhill, 116-47. New York: Oxford University Press, 2005.

"The New Bilateralism in the Asia Pacific." Third World Quarterly 24, no. 2 (2003): 299-317.

"A Three Bloc World? The New East Asian Regionalism." International Relations of the Asia-Pacific 2 (2002): 167-95.

"APEC Adrift: Implications for Economic Regionalism in Asia and the Pacific." The Pacific Review 13, no. 2 (June 2000): 319-33.

Ravenhill, John, and Yang Jiang. "China's Move to Preferential Trading: A New Direction in China's Diplomacy." Journal of Contemporary China 18, no. 58 (2009).

Reardon, Lawrence. The Reluctant Dragon: Crisis Cycles in Chinese Foreign Economic Policy. Seattle and London: University of Washington Press, 2002.

Ren, Juntao. "Guangxi's Investment and Financing Measures in 'Two Corridors and One Circle' Cooperation." Around Southeast Asia, no. 5 (2006): 52-55.

Renwick, Neil, and Qing Cao. "China's Political Discourse Towards the 21st Century: Victimhood, Identity, and Political Power." East Asia: An International Quarterly 17, no. 4 (Winter 1999): 111-43.

Robinson, Thomas W., and David L. Shambaugh. Chinese Foreign Policy: Theory and Practice. Oxford and New York: Clarendon Press; Oxford University Press, 1994.

Rodrik, Dani. "The Rush to Free Trade in the Developing World: Why So Late? Why Now? Will It Last?" In Voting for Reform: Democracy, Political Liberalization, and Economic 
Adjustment, edited by H. Stephen and S. Webb, 61-88. New York: Oxford University Press, 1994.

Rong, Min. "Speech at the Australia-China Free Trade Conference." Shenzhen, 28-29 June 2006. Roseneau, James N., ed. Linkage Politics: Essays on the Convergence of National and International Systems. New York, London: The Free Press, Collier-MacMillan, 1974.

Saich, Tony. Governance and Politics of China. 2nd ed. Basingstoke, Hampshire [UK]; New York: Palgrave Macmillan, 2004.

Scalapino, Robert A. "China's Multiple Identities in East Asia: China as a Regional Force." In China's Quest for National Identity, edited by Lowell Dittmer and Samuel S. Kim. Ithaca and London: Cornell University, 1993.

Schott, Jeffrey J. "Assessing Us FTA Policy." In Free Trade Agreements: Us Strategies and Priorities, edited by Jeffrey J. Schott, 359-81. Washington D.C.: Peterson Institute, 2004.

Shambaugh, David L. Power Shift: China and Asia's New Dynamics. Berkeley: University of California Press, 2005.

. "China's International Relations Think Tanks: Evolving Structure and Process." The China Quarterly, no. 171 (2002): 575-96.

Shang, Guoji. 2005. China-ASEAN FTA's Experiment Field: The Early Harvest Program. Online at: gjs.mofcom.gov.cn/accessory/200509/1127371793253.doc.

Sheng, Bin. Zhongguo Duiwai Maoyi Zhengce De Zhengzhi Jingji Fenxi [the Political Economy of China's Foreign Trade Policies]. Shanghai: Shanghai Sanlian, 2002.

Sheng, Lijun. "China-ASEAN Free Trade Area: Origins, Developments and Strategic Motivations." ISEAS Working Paper: International Politics and Security Issues Series, no. 1 (2003).

Shi, Benzhi, and Jie Dai, eds. Lancang Jiang- Meigong He Ci Quyu Hezuo Yu ZhongguoDongmeng Ziyou Maoyi Qu Jianshe [Lancang-Mekong River Sub-regional Cooperation and the Construction of China-ASEAN Free Trade Area]. Beijing: China Commerce and Trade Press, 2005.

Shirk, Susan L. China, Fragile Superpower: How China's Internal Politics Could Derail Its Peaceful Rise. New York: Oxford University Press, 2007.

How China Opened Its Door: The Political Success of the PRC's Foreign Trade and Investment Reforms, Integrating National Economies. Washington, D.C.: Brookings Institution, 1994.

. The Political Logic of Economic Reform in China, California Series on Social Choice and Political Economy; 24. Berkeley: University of California Press, 1993.

Skidmore, Thomas. "The Politics of Economic Stabilization in Postwar Latin America." In Authoritarianism and Corporatism in Latin America, edited by James M. Malloy, 14990. Pittsburgh, Penn.: Pittsburgh University Press, 1977.

Smith, Alexandra. "Free Trade Agreement Jeopardises Local Workers." Sydney Morning Herald, 3 May 2005.

Smith, Warwick. "Speech at the Australia-China FTA Services Conference." Beijing, 24 April 2006.

Song, Hong. "Non-Market Economy Status and the Development of China's Foreign Trade." World Economy and Politics, no. 10 (2004).

Song, Yufang. "Speech at the Australia-China Free Trade Conference." Shenzhen, 28-29 June 2006.

Stanford, Jim, and Pat Conroy. The Potential Employment Impacts of an Australia-China Free Trade Agreement: the Australian Manufacturing Workers Union, 2007.

Steinfeld, Edward. "Embrace of Capitalism: China Ten Years after the Asian Financial Crisis." In Crisis as Catalyst: Asia's Dynamic Political Economy, edited by Andrew Macintyre, T.J. Pempel and John Ravenhill, 183-205. Ithaca: Cornell University Press, 2008.

Steinmo, Sven, Kathleen Ann Thelen, and Frank Longstreth. Structuring Politics: Historical Institutionalism in Comparative Analysis, Cambridge Studies in Comparative Politics. Cambridge [England]; New York: Cambridge University Press, 1992.

Stewart, Terence P. "China's Compliance with World Trade Organization Obligations: A Review of China's 1st Two Years of Membership." U.S.-China Security and Economic Review Commission, 2004. 
Stoler, Andrew L. "Market Economy Status for China: Implications for Antidumping Protection in Australia." The Australia-China Free Trade Agreement Conference, Sydney 13 August 2004.

Sucharitkul, Sompong "Report on the Second China-ASEAN Expo" Chinese Journal of International Law 5, no. 2 (2006): 397-421.

Sun, Jie. "Shenhua Yazhou Jinrong Hezuo de Tujing: Riben de Zuoyong he Yingxiang [Ways to Deepen Asian Financial Cooperation: Japan's Role and Influence]." Shijie Jingji yu Zhengzhi [World Economy and Politics], no. 5 (2007): 59-66.

Sun, Xin, and Changwen Xu. Zhong Ri Han Jingji Hezuo Cujin Dongya Fanrong [ChinaJapan-Korea Economic Cooperation for East Asian Prosperity]. Beijing: China Customs Press, 2005.

Sussangkarn, Chalongphob. "Thailand and the China-ASEAN FTA." Thailand Development Research Institute Quarterly Review (March 2003).

Sutter, Robert G. China's Rise in Asia: Promises and Perils. Lanham, MD.: Rowman \& Littlefield, 2005.

Suzuki, Sanae. "Chairmanship in ASEAN+3: A Shared Rule of Behavior." Japan Institute of Developing Economies Discussion Paper, no. 9 (October 2004).

Tanner, Murray S. "The National People's Congress." In The Paradox of China's Post-Mao Reforms, edited by Merle Goldman and Roderick MacFarquhar, 100-28. Cambridge, Mass.: Harvard University Press, 1999.

Tao, Jian, and Fengying Chen. "Dongya Jinrong Weiji Baolu de Xin Wenti he Yinqi de Xin Bianhua [New Problems and Changes from East Asian Financial Crisis]." Shijie Jingji yu Zhengzhi [World Economy and Politics], no. 7 (1998).

Taylor, John. "China Fears FTA's Impact on Farming." ABC Australia, 22 March 2005.

Teo, Eric Chu Cheow. "Paying Tribute to Beijing: An Ancient Model for China's New Power." International Herald Tribune January 21, 2004.

Thelen, Kathleen, and Sven Steinmo. "Historical Institutionalism in Comparative Politics." In Structuring Politics: Historical Institutionalism in Comparative Analysis, edited by Sven Steinmo, Kathleen Ann Thelen and Frank Longstreth, 1-32. Cambridge [England]; New York: Cambridge University Press, 1992.

Thomson, Graeme. "Trade Policy Issues." The Australia-China Free Trade Agreement Conference, Sydney, 12-13 August 2004.

Tian, Kechuan "Fine Wool Industry in China and the Free Trade between China and Australia." the Australia-China FTA Agricultural Conference, Xi'an, 27 September 2006.

Toy, Mary-Anne. "China Free Trade Talks Drag on, and on, and on." Sydney Morning Herald, 23 June 2007.

Trentmann, Frank. "Political Culture and Political Economy: Interest, Ideology and Free Trade." Review of International Political Economy 5, no. 2 (Summer 1998): 217-51.

Tsebelis, George. "Decision Making in Political Systems: Veto Players in Presidentialism, Parliamentarism, Multicameralism and Multipartyism." British Journal of Political Science (July 1995): 289-325.

Tu, Jianjun. "Safety Challenges in China's Coal Mining Industry." China Brief 7, no. 1 (10 January 2007).

Van Ness, Peter. "China as a Third World State: Foreign Policy and Official National Identity." In Working Paper. Canberra: Department of International Relations, Research School of Pacific and Asian Studies, Australian National University, 1991.

Viner, Jacob. The Customs Union Issue. New York, Carnegie Endowment for International Peace, 1950.

Wang, Mengkui. "Yazhou Jinrong Weiji yu Zhongguo [Asian Financial Crisis and China]." Qiushi [Seeking Truth] 21 (1998).

Wan, Mingxu. "Guangxi's "Access to ASEAN": Problems and Solutions." Around Southeast Asia, no. 2 (2006): 61-66.

Wang, Shaoguang. "The Social and Political Implications of China's WTO Membership." Journal of Contemporary China 9, no. 25 (2000): 373-405.

Wang, Shichun, and Ye Quanliang. "Non-Market Economy Status: Anti-Dumping and Countermeasures." Finance and Trade Economics, no. 5 (2005). 
Wang, Shilu, ed. 2005-2006 Dongnan Ya Baogao [Southeast Asia Report 2005-2006], Yunnan Blue Books. Kunming: Yunnan University Press, 2006.

Wang, Weijun. "Yazhou Huobi Jijin de Youlai ji Qianzhan [The Background and Prospects of the Asian Monetary Fund]." Xin Jinrong [New Finance], no. 92001): 30-32.

Wang, Yong. "Causes, Impacts of the Asian Financial Crisis and China's Measures: A Summary of the Symposium 'Asian Financial Crisis: Views from China and the US' Conference." Meiguo Yanjiu [American Studies], no. 3 (1998): 147-52.

Wang, Yong. "China's Domestic WTO Debate." The China Business Review 27, no. 1 (January/February 2000): 54-58.

Wang, Yunjong, and Deok Ruong Yoon. 2004. "Mechanisms of Regional Surveillance in East Asia and Its Prospects." Online at: http://www.mof.go.jp/jouhou/kokkin/tyousa/tyou041e.pdf.

Wang, Zixian. "Oиуиап yи Dongya Jinrong Hezuo [Euro and East Asian Financial Cooperation]." Shijie Jingji [World Economy], no. 3 (2000): 70-72.

Wattanapruttipaisan, Thitapha. "ASEAN-China Free Trade Area: Advantages, Challenges, and Implications for the Newer ASEAN Member Countries." ASEAN Economic Bulletin 20, no. 1 (April 2003): 31-48.

Weber, Douglas. "Two Funerals and a Wedding? The Ups and Downs of Regionalism in East Asia and Asia-Pacific after the Asian Crisis." The Pacific Review 14, no. 3 (2001): 339 72.

Wei, Shang-Jin, and Jeffrey A. Frankel. "Can Regional Blocs Be a Stepping-Stone to Global Free Trade? A Political Economy Analysis." International Review of Economics and Finance 5, no. 4 (1996): 339-47.

Weiss, Linda, Elizabeth Thurbon, and John A. Mathews. How to Kill a Country: Australia's Devastating Trade Deal with the United States. Crows Nest, N.S.W.: Allen \& Unwin, 2004.

Williamson, John. ed. The Political Economy of Policy Reform. Washington, D.C.: Institute for International Studies, 1994.

Wintrobe, Ronald. The Political Economy of Dictatorship. New York: Cambridge University Press, 1998.

Wong, John and Wei Liu eds. China's Surging Economy: Adjusting for More Balanced Development. Singapore: World Scientific, 2007.

Woods, Lawrence T. "Delicate Diplomatic Debuts: Chinese and Soviet Participation in the Pacific Economic Cooperation Conference." Pacific Affairs 63, no. 2 (Summer 1990): 210-27.

Wu, Zheng, and Lu Xiao. "Warns of Protectionism Wu: Keep Regional Trade Open." China Daily, Apr 11, 1997.

Xiao, Qi. "Ziben Xiangmu Kaifang yu Jinrong Anquan [Capital Account Liberalization and Financial Security]." Jinrong Jiaoxue yu Yanjiu [Finance Education and Studies], no. 3 (2006).

$\mathrm{Xu}$, Changwen, Guanghui Li, and Wei Li. Zhongguo Lingpao Dongya Jingji Hezuo [China Leading the Race of East Asian Economic Cooperation]. Beijing: China Customs Press, 2003.

Xue, Fengxuan, and Dadao Lu. China's Regional Disparities: Issues and Policies. Huntington, N.Y.: Nova Science Publishers, 2001.

Yahuda, Michael. "How Much Has China Learned About Interdependence?" In China Rising: Nationalism and Interdependence, edited by David S.G. Goodman and Gerald Segal, 7 26. London and New York: Routledge, 1997.

Yang, Jiechi. "Deepen All-round Cooperation and Promote Common Prosperity, Speech by Vice Minister Yang Jiechi of the Ministry of Foreign Affairs of the People's Republic of China at the Asia Society of AustralAsia Center in Melbourne" 13 December 2005, online at http://au.china-embassy.org/eng/sgfyrth/t226994.htm.

Yang, Ning. "The Investment of Chinese Garment Industry in Cambodia." Around Southeast Asia, no. 4 (2006): 40-43.

Yawazama, Ippei and Robert Scollay. "Towards an Assessment of APEC Trade Liberalization and Facilitation." In APEC as an Institution: Multilateral Governance in the Asia- 
Pacific, edited by Richard E. Feinberg, 111-30. Singapore: Institute of Southeast Asian Studies, 2003.

Ye, Shuguang. "Chinese Enterprises Investing and Doing Business in the Great Mekong SubRegion." Around Southeast Asia, no. 3 (2006): 52-56.

Yu, Yongding. "Yazhou Jinrong Weiji 10 Zhounian he Zhongguo Jingji [10th Anniversary of Asian Financial Crisis and Chinese Economy]." Guoji Jinrong Yanjiu [International Financial Studies], no. 8 (2007): 1-13.

Yu, Yongding, Fan He, and Jing Li. "Yazhou Jinrong Hezuo: Beijing, Zuixin Jinzhan yu Fazhan Qianjing [Asian Financial Cooperation: Background, Progress and Prospects]." Guoji Jinrong Yanjiu [International Financial Studies], no. 2 (2002): 6-12.

Zha, Daojiong. "The Politics of China-ASEAN Economic Relations: Assessing the Move toward a Free Trade Area." Asian Perspective 26, no. 4 (2002): 53-82.

Zhang, Bin. "Yazhou Huobi Jijin de Fuhuo [The Revival of Asian Monetary Fund]." Dangdai Yatai [Contemporary Asia-Pacific Studies], no. 1 (2001): 18-24.

Zhang, Bin, and Fan He. "Is Asian Currency Unit Attractive to East Asian Economies?" China and World Economy 15, no. 1 (January-February 2006): 62-76.

Zhang, Cungen. "Speech at the Australia-China FTA Agricultural Conference." Xi'an, 27 September 2006.

Zhang, Jianzhong. "The Complementarity of Trade between Guangxi and Vietnam." Around Southeast Asia, no. 1 (2006): 26-30.

Zhang, Rui. "Anti-Dumping: Developing Countries 'Targeting' China." High-Tech (October 2005).

Zhang, Xuebin. "Lun Zhong Mei Liangguo zai Yazhou Jinrong Weiji zhong de Biaoxian [The Performances of China and the US in the Asian Financial Crisis]." Guoji Zhengzhi Yanjiu [International Politics Studies], no. 2 (1999): 40-48.

Zhang, Yanling. "Bring Bank of China's Strengths into Play and Provide Diversified Services to Promote Sino-Australia Trade." The Australia-China FTA Services Conference, Beijing, 24 April 2006.

Zhang, Yongjin, and Greg Austin. Power and Responsibility in Chinese Foreign Policy. Canberra: Asia Pacific Press, 2001.

Zhang, Yunling. East Asian Regionalism and China. Beijing: World Affairs Press, 2005. , ed. Shijie Quyuhua De Fazhan Yu Moshi [the Development and Models of Regionalization in the World]. Beijing: World Affairs Press, 2004. ,ed. East Asian Cooperation: Progress and Future. Beijing: World Affairs Press, 2003.

Zhang, Yunling, and Shihai Sun, eds. Yatai Diqu Fazhan Baogao 2005 [Asia Pacific Regional Development Report 2005]. Beijing: Social Sciences Literature Press, 2006.

Zhang, Yunling, and Bin Zhang. "Dongya Jinrong Hezuo de Jinzhan yu Weilai de Xuanze [Progress in Asian Financial Cooperation and Future Choices]." Dangdai Yatai [Contemporary Asia Pacific], no. 8 (2002): 3-13.

Zhang, Yunling, and Jianglin Zhao, eds. Yatai Quyu Hezuo De Fazhan [Developments of Asia Pacific Cooperation]. Beijing: World Affairs Press, 2003.

Zhang, Yunling, and Xiaobing Zhou, eds. Dongya Hezuo De Jincheng Yu Qianjing [The Progress and Prospect of East Asian Cooperation]. Beijing: World Affairs Press, 2003.

Zhao, Quansheng. Interpreting Chinese Foreign Policy: The Micro-Macro Linkage Approach. Hong Kong; New York: Oxford University Press, 1996.

Zheng, Bijian. China's Peaceful Rise: Speeches of Zheng Bijian 1997-2005. Washington D.C.: Brookings Institution Press, 2005.

Zhong, Wei. "1 3 niannei, Naxie Yinsu Keneng Yingxiang Woguo Jinrong Wending [Within 1-3 Years, Which Factors May Affect China's Financial Stability?]." Diyi Caijing Ribao [First Finance Daily], 5 May 2008

Zhong, Wei. "Dongya hezuo zou ziji de lu [East Asian Cooperation Walks Our Own Way]." Huanqiu shibao [Global Times], 13 May 2002.

Zhou, Qun. "Economic and Trade Relations between Yunnan and ASEAN in 2005." Commerce of Yunnan, no. 1 (March 2006).

Zhu, Min. "Quanqiu Liudong Guosheng Beijing xia de Dongya Jinrong Hezuo [East Asian Financial Cooperation in Excess Global Liquidity]." Waijiao Pinglun [Review of Diplomacy], no. 3 (2007): 21-23. 
Zhu, Yi. "Zhengfu xinjigou zhongbang dengchang [Government New Institutions Big Launch]." Economic Outlook of the Bohai Sea no. 11 (2002).

Zoellick, Robert. "Unleashing the Trade Winds." The Economist, 7 December 2002, 27-29.

Zweig, David. Internationalizing China: Domestic Interests and Global Linkages, Cornel

Studies in Political Economy. Ithaca: Cornell University Press, 2002. 